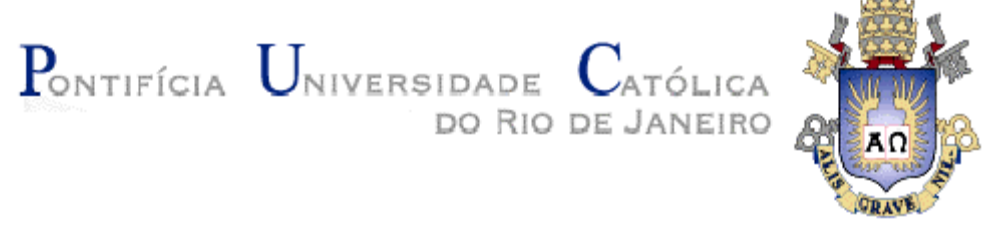

Priscila Matos Resinentti

\title{
DIMENSÕES DA QUALIDADE EDUCACIONAL NA REDE MUNICIPAL DO RIO DE JANEIRO: \\ ENTRE AS FORMAÇÕES ACADÊMICA E CULTURAL - O PROJETO ESCOLA E MUSEU
}

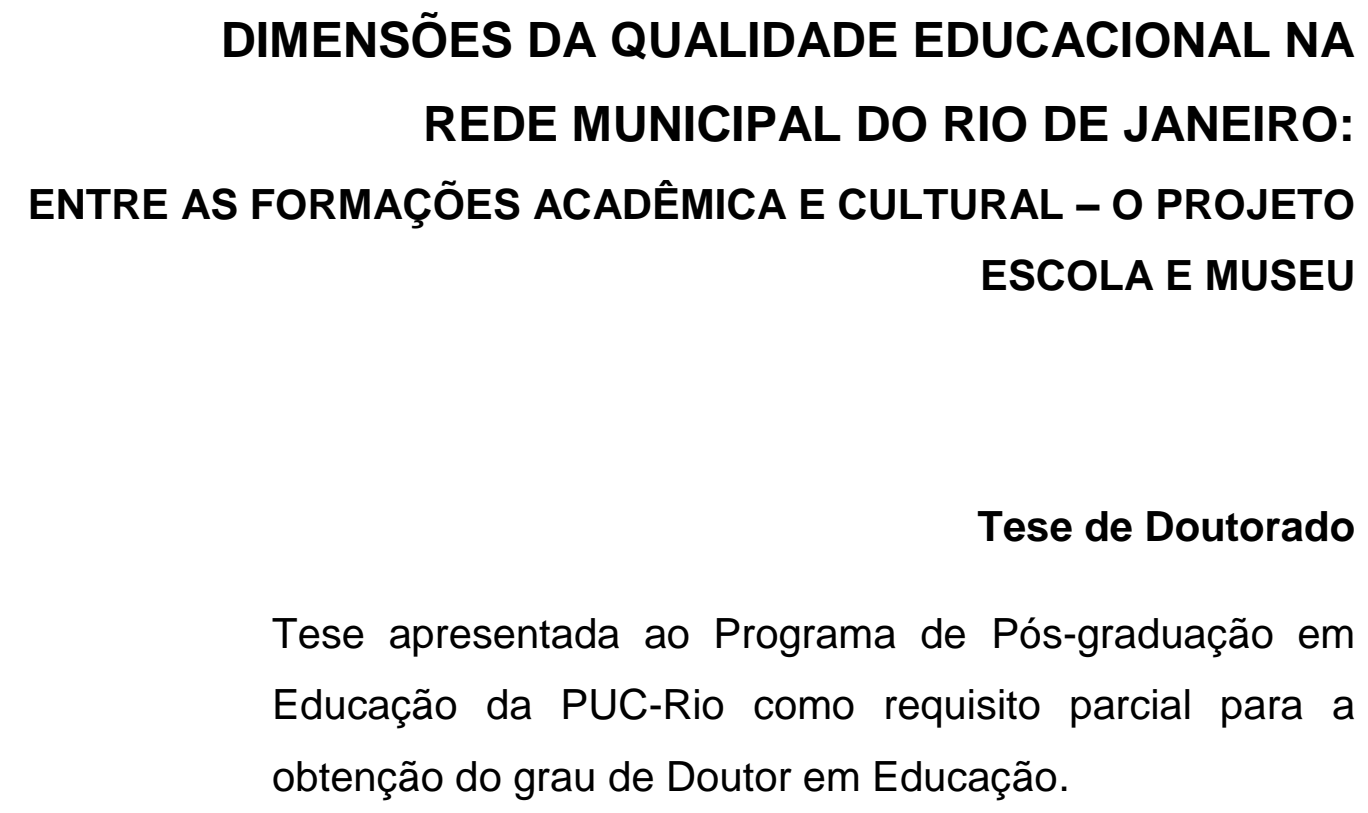

Orientadora: Prof. Maria Cristina Monteiro Pereira de Carvalho 


\title{
DIMENSÕES DA QUALIDADE EDUCACIONAL NA REDE MUNICIPAL DO RIO DE JANEIRO: ENTRE AS FORMAÇÕES ACADÊMICA E CULTURAL - O PROJETO
} ESCOLA E MUSEU

\begin{abstract}
Tese apresentada como requisito parcial para obtenção do grau de Doutor pelo Programa de Pós-graduação em Educação do Departamento de Educação do Centro de Teologia e Ciências Humanas da PUC-Rio. Aprovada pela Comissão Examinadora abaixo assinada.
\end{abstract}

Profa. Maria Cristina Monteiro Pereira de Carvalho Orientadora Departamento de Educação - PUC-Rio

Prof. Ralph Ings Bannell Departamento de Educação - PUC-Rio

Profa. Sonia Kramer Departamento de Educação - PUC-Rio

Profa. Sibele Cazelli Ministério de Ciência e Tecnologia

Prof. Ozias de Jesus Soares Museu da Vida/COC/ Fiocruz

Prof. ${ }^{a}$ Monah Winogrand Coordenadora Setorial do Centro de Teologia e Ciências Humanas

PUC-Rio 
Todos os direitos reservados. É proibida a reprodução total ou parcial do trabalho sem autorização da universidade, da autora e da orientadora.

\section{Priscila Matos Resinentti}

Possui graduação em Ciências Biológicas - Licenciatura pela Universidade Federal do Rio de Janeiro (2006), especialização em Educação Básica pela UERJ (2009) e mestrado em Educação pela Pontifícia Universidade Católica do Rio de Janeiro (2012). Integra o Grupo de Estudo e Pesquisa em Educação, Museu, Cultura e Infância (GEPEMCI), ligado ao Departamento de Educação da Pontifícia Universidade Católica do Rio de Janeiro. Atua como coordenadora de área (ciências e biologia) e professora de biologia na rede privada. Na Secretaria Municipal de Educação do Rio de Janeiro é professora de ciências integrante da equipe da Gerência de Avaliação.

Ficha Catalográfica

Resinentti, Priscila Matos

Dimensões da qualidade educacional na rede municipal do Rio de Janeiro : entre as formações acadêmica e cultural - o projeto escola e museu / Priscila Matos Resinentti ; orientadora: Maria Cristina Monteiro Pereira de Carvalho. - 2017.

230 f. : il. color. ; $30 \mathrm{~cm}$

Tese (doutorado)-Pontifícia Universidade Católica do Rio de Janeiro, Departamento de Educação, 2017.

Inclui bibliografia

1. Educação - Teses. 2. Formação cultural. 3. Equipamentos culturais. 4. Educação não formal. 5. Formação acadêmica. I. Carvalho, Maria Cristina Monteiro Pereira de. II. Pontifícia Universidade Católica do Rio de Janeiro. Departamento de Educação. III. Título. 
Ao meu filho por possibilitar vivenciar novas experiências e conhecer uma outra dimensão do amor.

Aos meus pais, marido e irmão por sonharem junto comigo e possibilitarem o meu voo. 


\section{Agradecimentos}

A lista de agradecimentos é muito grande, pois muitos ajudaram na caminhada até aqui. Agradeço:

Primeiramente a Deus. Sem Ele em minha vida eu nada seria. Por tudo o que fez, faz e irá fazer eu agradeço de todo o meu coração e entendimento. Foram muitas lutas e lágrimas, mas guardei a fé na certeza de que nunca estive só. Como diz em Jeremias 29:11: "Porque eu bem sei os pensamentos que tenho a vosso respeito, diz o Senhor; pensamentos de paz, e não de mal, para vos dar o fim que esperais."

Eu queria ter mais que uma voz

Mais que um amor e uma vida pra te oferecer

Pois tu és muito mais que eu possa ter em meu ser

Tu és o autor, aquele que

Pintou com perfeição a vida

Tu és o Senhor, aquele que

Me amou e és o

Meu Deus, meu Senhor

Minha vida é pra teu louvor

Meu Deus, meu Senhor

Minha vida é pra teu louvor

(Kleber Lucas)

Meu Jesus, maravilhoso és

Minha inspiração a prosseguir

E mesmo quando tudo não vai bem

Eu continuo olhando para $\mathrm{Ti}$

Pois sei que Tu tens o melhor pra mim

Há um segredo no Teu coração

Oh! Dá-me forças pra continuar

Guardando a promessa em oração

Firme, oh, Deus está o meu coração

Firme nas promessas do Senhor

Eu continuo olhando para $\mathrm{Ti}$

$\mathrm{E}$ assim eu sei que posso prosseguir

E mesmo quando eu chorar

As minhas lágrimas serão

Para regar a minha fé

E consolar meu coração

Pois o que chora aos pés da cruz

Clamando em nome de Jesus

Alcançará de Ti Senhor

Misericórdia, Graça e luz 


\section{Teu grande amor não cessa \\ Eterno não tem fim \\ Quão grande És Tu Senhor \\ Quão grande És pra mim \\ Tua graça é o meu refúgio \\ Descanso no Teu poder \\ Maravilhoso és, Maravilhoso és \\ Pra mim}

(Kleber Lucas)

Aos meus pais, Edilde e Luiz, e irmão, Luiz, por me apoiarem e me encorajarem em toda a minha jornada. Serão sempre o meu porto seguro e grandes exemplos para mim. Especialmente, a minha mãe, pelas palavras e gestos de carinho, orações e cuidados com o meu pequeno Rafael para que fosse possível concluir a escrita da tese. $\mathrm{O}$ meu amor por vocês é infinito e o uso das palavras sempre serão insuficientes perante a minha gratidão.

Ao meu marido, pelo amor, companheirismo e por incentivar cada sonho meu como se fosse o próprio sonho. Por compreender as minhas ausências, ter paciência e por se aventurar comigo na paternidade. Não poderia ter melhor marido e pai para o nosso Rafael. Amo muito você!

Ao meu filho e grande razão da minha vida, por todos os momentos que precisei abrir mão de brincar e passear com você para escrever. Você foi gerado junto com essa pesquisa, esteve no interior do meu útero em todas as observações de campo e ao meu lado durante as análises e confecção da tese. Te amo de um modo indescritível.

A minha orientadora, professora Cristina Carvalho, primeiro por ter partilhado tantos conhecimentos comigo e por ter, de modo tão generoso, me orientado e incentivado em todas as decisões. Sempre com um olhar e ações verdadeiros, tentando se colocar no meu lugar. Pelo carinho, no momento mais difícil da minha vida, quando meu filho nasceu e imediatamente foi hospitalizado e meu marido estava desempregado. Todos os dias se importou conosco e torceu pelo nosso sucesso. Celebrou a vida do Rafinha e a conquista do Dudu. Você tem um lugar especial no meu coração.

À Coordenação de Aperfeiçoamento de Pessoal de Nível Superior (CAPES) e à PUC-Rio, pelos auxílios concedidos que foram fundamentais para que a pesquisa fosse realizada.

Às professoras Cristina Carvalho, Alicia Bonamino, Sonia Kramer e Sibele Cazelli, que nas minhas qualificações teceram importantes considerações e iluminaram esta pesquisa.

Aos integrantes da banca avaliadora, Sonia Kramer, Ralph Bannell, Sibele Cazelli e Ozias de Jesus Soares, grata por terem aceitado o convite e contribuírem com o olhar para esta pesquisa. 
Aos meus queridos amigos que estiveram comigo, e em especial, as meninas do GEPEMCI (Grupo de Pesquisa e Estudo em Educação, Museu, Cultura e Infância). Vocês foram minhas companheiras e ajudadoras, contribuíram muito com seus conhecimentos e nas tarefas de campo. Agradeço de modo mais especial à Thamiris Lopes por tanta atenção às minhas questões, tornando-se um presente em minha vida.

À Secretaria Municipal de Educação do Rio de Janeiro e todos os seus profissionais, em especial, ao Setor de Extensividade, por ter permitido acompanhar o Projeto Escola e Museu. Aos amigos da Gerência de Avaliação pela torcida e por proporcionarem a realização de um sonho: trabalhar no nível central.

Aos professores entrevistados, por terem partilhado experiências. Seus contributos foram essenciais para a pesquisa.

Aos alunos de todas as escolas da rede municipal. Vocês são a razão da docência. Desejo que possam ter experiências surpreendentes na trajetória escolar tanto na dimensão acadêmica quanto na cultural. Com vocês não só ensino, mas aprendo todos os dias. 


\section{Resumo}

Resinentti, Priscila Matos; Carvalho, Maria Cristina Monteiro Pereira de (Orientadora). Dimensões da qualidade educacional na rede municipal do Rio de Janeiro: entre as formações acadêmica e cultural - o Projeto Escola e Museu. Rio de Janeiro, 2017. 230p. Tese de Doutorado Departamento de Educação, Pontifícia Universidade Católica do Rio de Janeiro.

Esta tese tem como objetivo discutir o padrão de acesso dos alunos da rede municipal de educação da cidade do Rio de Janeiro aos equipamentos culturais parceiros da prefeitura no Projeto Escola e Museu. Em geral, a promoção cultural se dá através do diálogo das escolas com instituições diretamente ligadas à cultura como museus, centros culturais, bibliotecas, teatros e planetários. Entretanto, em tempos de responsabilização docente baseada em índices construídos a partir dos resultados das avaliações em larga escala, será que há possibilidades para a formação cultural em espaços de educação não formal? $\mathrm{O}$ referido objetivo se desdobra em questões que orientam a investigação: Como as escolas se apropriam dos equipamentos culturais, especialmente dos museus parceiros da SME/RJ? A escola valoriza o diálogo com os espaços de educação não formal? Quais experiências os alunos da rede estão vivenciando nos equipamentos culturais? Para a realização do estudo, foram adotadas as seguintes estratégias metodológicas: i) observação das atividades realizadas com os alunos do ensino fundamental em sete museus e centros culturais parceiros da Secretaria Municipal de Educação (SME/RJ) no Projeto Escola e Museu; ii) realização de entrevistas com a coordenadora do Projeto Escola e Museu e com os docentes participantes; iii) análise documental do projeto, através de textos secundários. A investigação aborda as contribuições dos Estudos sobre Avaliação e Desempenho e Estudos sobre Cultura e Formação Cultural, campos que permitiram investigar as relações entre formação acadêmica e formação cultural no âmbito das políticas públicas educacionais. A pesquisa problematiza a questão da formação cultural fundamentada em autores como Hans-Georg Gadamer e John Dewey. A hipótese que engendrou a pesquisa foi a de que o acesso dos alunos aos equipamentos 
culturais através do Projeto Escola e Museu pode contribuir para a ampliação da formação cultural, em uma dimensão de experiência crítica, que proporcione o desenvolvimento da emoção estética e a inserção do aluno na sociedade na perspectiva cultural. A partir das análises, as conclusões encontradas foram: (i) em contexto de responsabilização docente, o Projeto Escola e Museu configura-se um exemplo de bom uso dos resultados das avaliações externas, à medida que as escolas participantes são selecionadas a partir de critérios como, por exemplo, estarem situadas em áreas conflagradas da cidade e apresentarem baixo desempenho. Logo, através desse projeto, pode-se perceber uma estratégia de tentar promover a equidade na rede; (ii) o Projeto Escola e Museu cumpre os seus objetivos por: promover o acesso de professores e alunos a museus, centros, institutos de arte e cultura, como atividade articulada ao desenvolvimento do Currículo; estimular a valorização do patrimônio cultural da cidade; estimular a formação de público de visitação a instituições e espaços culturais decorrente do desenvolvimento do interesse de alunos e professores pela apropriação de bens culturais; possibilitar aos alunos aprofundar e diversificar as formas de aprendizagem dos conteúdos das distintas áreas do conhecimento, proporcionados nas visitas às instituições culturais; (iii) o Projeto também apresenta aspectos que precisam ser melhorados tais como: o atendimento restrito aos alunos do $8^{\circ}$ ano; número reduzido de escolas participantes; concentração dos equipamentos culturais na zona sul e no centro da cidade e problemas relacionados ao deslocamento.

\section{Palavras-chave}

Formação cultural; equipamentos culturais; educação não formal; formação acadêmica. 


\section{Abstract}

Resinentti, Priscila Matos; Carvalho, Maria Cristina Monteiro Pereira de (Advisor). Dimensions of educational quality in the municipal network of Rio de Janeiro: between academic and cultural formation - The School and Museum Project. Rio de Janeiro, 2017. 230p. Tese de Doutorado - Departamento de Educação, Pontifícia Universidade Católica do Rio de Janeiro.

This thesis aims to discuss the access pattern of the students of the Municipal Education Network of the city of Rio de Janeiro (SME/RJ) to the cultural facilities partners of the city hall in the Project School and Museum. In general, cultural promotion takes place through the dialogue of schools with institutions directly linked to culture such as museums, cultural centers, libraries, theaters and planetariums. However, in times of teacher accountability based on indexes constructed from the results of large-scale evaluations, is there any possibility for cultural formation in non-formal education spaces? This objective is deployed on issues that guide this research: How do schools take ownership of cultural facilities, especially from SME / RJ partner museums? Does the school value dialogue with non-formal education spaces? What experiences are network students having with the cultural equipment? In order to carry out the study, the following methodological strategies were adopted: i) observation of the activities carried out with elementary school students in seven museums and cultural centers partners of the Municipal Department of Education (SME / RJ) in the School and Museum Project; ii) interviews with the coordinator of the School and Museum Project and with the participating teachers. The research deals with the contributions of the Studies on Assessment and Performance and Studies on Culture and Cultural Formation, fields that allowed to investigate the relations among academic formation and cultural formation in the scope of public educational policies. The research problematizes the question of cultural formation based on authors such as Hans-Georg Gadamer and John Dewey. The hypothesis that generated the research was that the students' access to cultural equipment through the School and Museum Project can contribute to the 
expansion of cultural formation, in a dimension of critical experience that provides the development of aesthetic emotion and the insertion of the student in society through the cultural perspective. From the analyzes, the conclusions were: (i) in the context of teacher accountability, the School and Museum Project is an example of good use of the results of external evaluations, as participating schools are selected based on criteria like if they are in areas of conflict in the city and have poor performance. Therefore, through this project, one can perceive a strategy of trying to promote equity in the network; (ii) the School and Museum Project fulfills its objectives by: promoting the access of teachers and students to museums, centers, institutes of art and culture, as an articulated activity to the development of the Curriculum; stimulate the appreciation of the city's cultural heritage; forming a visiting public for institutions and cultural spaces resulting from the development of the interest of students and teachers in the appropriation of cultural goods; enable students to deepen and diversify the ways of learning the contents of the different areas of knowledge, provided in visits to cultural institutions; (iii) the Project also presents aspects that need to be improved, for example: restricted attendance of the 8th grade students; reduced number of participating schools; concentration of cultural facilities in the south and center of the city and problems related to displacement.

\section{Keywords} training.

Cultural training; cultural equipment; non-formal education; academic 


\section{Sumário}

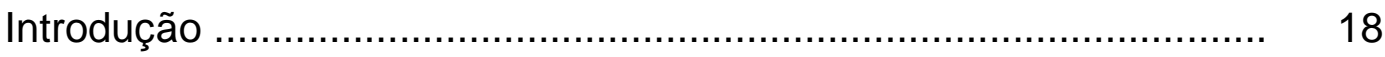

1.0. As dimensões da qualidade educacional.................................. 41

1.1. Avaliação e responsabilização docente .................................... 44

1.1.1. A avaliação externa em larga escala no Brasil: uma
história em construção ..............................................................

1.1.2. As temáticas avaliação e responsabilização docente nas pesquisas nacionais

1.1.3. Os instrumentos de regulação da Secretaria Municipal de Educação do Rio de Janeiro ............................................................... 56

2.0. Cultura, formação cultural e os espaços de educação não formal

2.1. Experiência e formação cultural de qualidade

2.2. Os contextos da influência, da produção e da prática da política de formação cultural

2.3. A questão da formação cultural na rede municipal ............... 93

2.4. Cultura para quem? ...................................................... 97

3.0. O Projeto Escola e Museu .................................................. 106

3.1. Uma análise do contexto da prática ....................................... 124

3.1.1. A seleção dos docentes participantes .............................. 125

3.1.2. A seleção dos alunos participantes .................................. 129

3.1.3. A reinterpretação por parte dos equipamentos culturais ... 134

4.0. A formação cultural de qualidade e as múltiplas experiências .... 161

4.1. O ambiente afeta as experiências educacionais: 0 acolhimento

4.2. A experiência permite o crescimento direcionado: os

roteiros e a mediação

4.3. Os hábitos afetam a formação de atitudes .................................. 173

4.4. Situações e modos de interação são inseparáveis ............... 176

5.0. Avaliação do Projeto Escola e Museu ...................................... 181

5.1. Avaliação realizada pelas instituições ................................ 181

5.2. Avaliação realizada pelos docentes .................................... 184

5.3. Avaliação realizada pelos alunos ....................................... 194

6.0. Considerações finais ........................................................ 206

7.0. Referências bibliográficas .................................................... 211

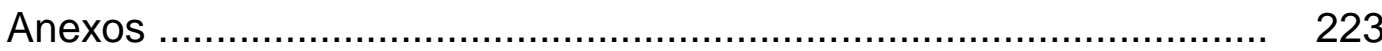




\section{Lista de llustrações}

Figura 01: Indicador de fluxo - proporção de aprovados ............ 69

Figura 02: Evolução e Ideb atual do segundo segmento do 75

ensino fundamental

Figura 03: Razões para não ir a museus

102

Figura 04: Exemplo de planejamento anual do Projeto Escola

e Museu

Figura 05: Avaliação do aluno ............................................... 115

Figura 06: Avaliação do professor ........................................... 116

Figura 07: Centro Cultural Banco do Brasil - Rio de Janeiro ... 136

Figura 08: Mulher sentada apoiada sobre os cotovelos em

"Picasso e a Modernidade Espanhola"

Figura 09: Centro Cultural do Poder Judiciário

Figura 10: Cicerones ícones da Justiça na atividade "Por dentro do

Palácio"

Figura 11: Centro Municipal de Arte Hélio Oiticica

Figura 12: Obra "Mother" em "Álbum de família"

Figura 13: Espaço Oi Futuro - Flamengo

Figura 14: Instalação "Caminhante” de Daniel Senise em "Quase aqui"

Figura 15: Fundação Eva Klabin

Figura 16: Instalação de Eduardo Berliner em "A presença da ausência"

Figura 17: Museu de Arte do Rio

Figura 18: Museu Nacional/UFRJ

Figura 19: Meteorito de Bendegó

Figura 20: Deusa Têmis

Figura 21: Obra Em Segredo (Exposição Álbum de família) ...... 168

Figura 22: Labirinto do fauno 
Esquema 1: As cinco áreas de conhecimento do setor de Extensividade (SME/RJ)

Mapa 1: Distribuição dos equipamentos culturais pertencentes à prefeitura do Rio de Janeiro por CRE

Mapa 2: Distribuição das escolas e dos equipamentos culturais pertencentes ao Projeto Escola e Museu (2015) 


\section{Lista de Tabelas, Gráficos e Quadros}

Tabela 1: Distribuição das escolas por divisão das CREs 28

Tabela 2: Distribuição dos equipamentos culturais pertencentes à 30 Prefeitura do Rio de Janeiro por CRE

Tabela 3: Quantitativo de alunos do ensino fundamental, escolas e 31 aparelhos culturais da prefeitura por CRE

Tabela 4: Quantitativo de Unidades Escolares participantes por CRE $\quad 37$

Tabela 5: Quantitativo de observações e entrevistas realizadas em $\quad 37$ cada instituição

Tabela 6: Razões para a não premiação às escolas que atendiam 65 ao segundo segmento em 2012

Tabela 7: Desempenho comparativo por CRE (2010 e 2012) 66

Tabela 8: Motivos para levar alunos a museus 119

Tabela 9: O que é uma visita bem sucedida 120

Tabela 10: Distância percorrida pelas escolas para chegarem aos 121 equipamentos culturais do Projeto Escola e Museu (2015)

Tabela 11: Quantitativo de alunos que responderam a avaliação 195

Tabela 12: Frequência em que são promovidas as atividades 199

Gráfico 1: Resultado do Ideb do segundo segmento do ensino 68 fundamental

Gráfico 2: Desempenho na Prova Brasil - Português (2013) 69

Gráfico 3: Desempenho na Prova Brasil - Matemática (2013) 69

Gráfico 4: Distribuição percentual do público escolar que visitou 97

museus e centros culturais da cidade do Rio de Janeiro

Gráfico 5: Percentual de pessoas que nunca frequentou atividades 98

culturais

Gráfico 6: Relação entre o grau de escolaridade (com nível superior) 98

e a não frequência às atividades culturais

Gráfico 7: Relação entre o grau de escolaridade (com nível 99

fundamental) e a não frequência às atividades culturais

Gráfico 8: Percentual de pessoas que nunca praticaram algumas 99

atividades culturais pela renda

Gráfico 9: Percentual de visitação aos museus nos últimos doze 100 meses por região de moradia dos entrevistados

Gráfico 10: Local de moradia do público potencial para os museus 101

Gráfico 11: A participação no projeto agregou conhecimento ao seu 105 trabalho?

Gráfico 12: Disponibilidade de transporte para o público visitante 
Gráfico 13: A participação no projeto agregou conhecimento ao seu 185 trabalho?

Gráfico 14: Você participou de todo o circuito interativo com seus 186 alunos(as)?

Gráfico 15: Qual museu e/ou centro cultural melhor recepcionou os 187 alunos durante o circuito interativo?

Gráfico 16: Qual museu e/ou centro cultural melhor dinamizou uma 188 atividade com os alunos durante o circuito interativo?

Gráfico 17: Objetivos apresentados para a realização da atividade 189

Gráfico 18: Recursos audiovisuais utilizados 189

Gráfico 19: Materiais apresentados para o enriquecimento dos 189 conteúdos

Gráfico 20: Informações obtidas durante a realização da atividade 190

Gráfico 21: Contribuição da atividade para a sua formação 190 profissional.

Gráfico 22: Aplicabilidade dos conhecimentos adquiridos no 190 ambiente de trabalho.

Gráfico 23: Produção de conhecimento para a melhoria da 190 qualidade do ensino

Gráfico 24: Sexo dos alunos respondentes 195

Gráfico 25: Você já visitou museu ou centro cultural antes do 196 projeto?

Gráfico 26: Considerando os temas abaixo, assinale aqueles que, 201 em sua percepção, foram abordados no Projeto

Gráfico 27: Você se considera um multiplicador?

202

Gráfico 28: Você já retornou a algum museu e/ou centro cultural para visitar, com familiares ou amigos, depois que participou do Projeto?

Gráfico 29: Qual museu e/ou centro cultural mais Ihe impressionou 203 durante o Projeto?

Quadro 1: Metas estabelecidas pela SME/RJ (2011) 59

Quadro 2: O que você recomendaria para melhorar esse projeto no 191 futuro?

Quadro 3: Em caso afirmativo, qual(quais) Museu(s) e Centro(s) 196

Cultural(is) já foram visitados?

Quadro 4: Com quem você fez a visita?

Quadro 5: Você considera importante conhecer os Museus e 199 Centros Culturais de sua cidade?

Quadro 6: O Projeto escola e Museu atendeu as suas expectativas? 200

Quadro 7: Justificativas para ter gostado de um determinado 203 equipamento cultural pertencente ao Projeto Escola e Museu. 


\section{Lista de ABREVIATURAS}

ANEB - Avaliação Nacional da Educação Básica

ANRESC - Avaliação Nacional do Rendimento Escolar

BNCC - Base Nacional Comum Curricular

CCBB/RJ - Centro Cultural Banco do Brasil do Rio de Janeiro

CCPJ - Centro Cultural do Poder Judiciário

CMAHO - Centro Municipal de Arte Hélio Oiticica

CRE - Coordenadoria Regional de Educação

ENEM - Exame Nacional do Ensino Médio

FEK - Fundação Eva Klabin

FNDE - Fundo Nacional de Desenvolvimento da Educação

GEA - Ginásio Experimental de Artes Visuais

GEC - Ginásio Experimental Carioca

GEPEMCI - Grupo de Estudo e Pesquisa em Educação, Museu, Cultura e Infância, da PUC-Rio

IBRAM - Instituto Brasileiro de Museus

ICOM - Conselho Internacional de Museus

Ideb - Índice de Desenvolvimento da Educação Básica

Ide-Rio - Índice de Desenvolvimento da Educação do Rio de

Janeiro

IDS - Índice de Desenvolvimento Social

INEP - Instituto Nacional de Estudos e Pesquisas Educacionais

Anísio Teixeira

MAST - Museu de Astronomia e Ciências Afins

IPHAN - Instituto do Patrimônio Histórico e Artístico Nacional

MAR - Museu de Arte do Rio

MEC - Ministério da Educação

MN/UFRJ - Museu Nacional da Universidade Federal do Rio de Janeiro

OCDE - Organização para a Cooperação e o Desenvolvimento

Econômico

PAR - Plano de Ações Articuladas

PCN - Parâmetros Curriculares Nacionais

PISA - Programme for International Student Assessment

PNC - Plano Nacional de Cultura

PNLD - Projeto Nacional do Livro Didático

PNM - Plano Nacional de Museus

PUC-Rio - Pontifícia Universidade Católica do Rio de Janeiro

SAEB - Sistema Nacional de Avaliação da Educação Básica

Sepe-RJ - Sindicato Estadual dos Profissionais de Educação

SME/RJ - Secretaria Municipal de Educação do Rio de Janeiro

TRI - Teoria da Resposta ao Item 


\section{Introdução}

Desempenho, formação cultural e responsabilização docente são aspectos que têm sido considerados relevantes na pauta de discussão sobre o desenvolvimento de uma educação de qualidade nas mais diferentes esferas, atravessando a vida política, acadêmica e social. Entretanto, existe uma tensão acerca dessas temáticas, já que, em muitos momentos, a qualidade educacional é resumida ao desempenho dos estudantes em avaliações externas padronizadas nas áreas de Língua Portuguesa e Matemática, e os resultados atingidos são de responsabilidade apenas dos docentes. E, por outro lado, as questões acerca da formação cultural ainda são pouco contempladas nas discussões sobre a qualidade educacional e nas pesquisas da área educacional.

Com a Constituição Federal de 1988, o ensino fundamental passou a ser considerado direito público subjetivo e, com a Emenda Constitucional n. 14, de 1996, garantiu-se o direito à educação em três domínios: acesso, permanência e padrão de qualidade. A Lei de Diretrizes e Bases da Educação de 1996 explicita, no artigo $3^{\circ}$, que o ensino será ministrado com base em princípios como a igualdade de condições para o acesso e permanência na escola e garantia de padrão de qualidade.

Para verificar a oferta de uma "educação de qualidade" em relação à aprendizagem, o governo federal criou um mecanismo de regulação: o Sistema Nacional de Avaliação da Educação Básica (Saeb), uma avaliação bianual, em caráter amostral, realizada pelo Instituto Nacional de Estudos e Pesquisas Educacionais Anísio Teixeira (Inep) para monitorar a qualidade da educação básica brasileira. O Saeb utiliza cinco instrumentos de coleta de dados: o teste ${ }^{1}$ de Língua Portuguesa e de Matemática e quatro questionários contextuais respondidos pelo aluno, pelo professor, pelo diretor e pelo responsável pela coleta dos dados na escola ${ }^{2}$ (Soares, 2004). Esse sistema de avaliação abriu não só a possibilidade de verificar resultados, mas também induziu estados e municípios a

\footnotetext{
${ }^{1}$ Não há uma definição consensual para os termos. Porém, no cotidiano escolar prova está associado a uma avaliação que será utilizada para definir o desempenho do aluno em relação a uma meta (que pode ser uma nota). Teste está associado a uma avaliação cujo objetivo é medir determinado aspecto. Geralmente os resultados dos testes são apresentados numa escala. Disponível em: http://academia.qedu.org.br/prova-brasil/o-que-e-a-prova-brasil/. Acesso em: 28 fev. 2017.

${ }^{2} \mathrm{O}$ desenho e a aplicação dessa avaliação ficaram sob a responsabilidade do Governo Federal.
} 
desenvolver iniciativas próprias de avaliação que dialogassem com as suas escolas.

No que diz respeito às políticas educacionais do Governo Federal, a mudança na presidência, em 2003, não provocou rupturas expressivas na reforma educacional herdada do governo anterior. Em 2005 foi criada a Prova Brasil, que, diferentemente do Saeb, é censitária e oferece dados não apenas para o Brasil e unidades da federação, mas também para cada município e escola participante. Essa mudança permitiu, em 2007, a criação pelo Inep do Índice de Desenvolvimento da Educação Básica (Ideb).

O Ideb é obtido a partir de dois componentes: taxa de rendimento escolar (aprovação) e média de desempenho nos exames padronizados de Matemática e Língua Portuguesa (foco em leitura) aplicados pelo Inep. Os índices de aprovação são obtidos a partir do Censo Escolar e as médias de desempenho utilizadas são as da Prova Brasil (para Idebs de escolas e municípios) e do Saeb (no caso dos Idebs dos estados e em âmbito nacional). Cada escola e rede de ensino recebe metas diferenciadas (Ideb) estabelecidas pelo Inep, com o objetivo de alcançar, até 2022, ano do bicentenário da Independência do Brasil, no mínimo, 6 pontos, que é a média correspondente ao sistema educacional dos países desenvolvidos. O Ideb atua, assim, como um indicador nacional que viabiliza o monitoramento da qualidade da Educação pelos sistemas de governo, pelas próprias escolas e pela população.

Com a Prova Brasil e com o Ideb, o Governo Federal passou a se relacionar diretamente com os municípios e com as escolas, não só no que se refere à aplicação de avaliações e ao estabelecimento de metas, mas também através da devolução dos resultados para cada escola participante e de ações de suporte técnico e financeiro.

Além das questões relacionadas ao baixo rendimento, a comunidade escolar vivencia momentos de crise e conflito de natureza diversa como, por exemplo, o aumento da violência intra e extraescolar, a formação acadêmica inadequada dos alunos, as diferentes condições de trabalho dos docentes, dentre outros, enfatizando a necessidade de iniciativas na resolução de questões educacionais. Essas características do contexto educacional precisarão ser consideradas e discutidas pelos cidadãos que terão que se posicionar, inclusive nas urnas eleitorais. 
Outros sinais dessa crise educacional podem ser percebidos no cenário atual da rede municipal do Rio de Janeiro. Em 2012, o candidato à reeleição à prefeitura da cidade do Rio de Janeiro fez recorrente uso em sua campanha eleitoral dos resultados do Ideb, já que a capital ficou entre as cinco melhores do Brasil no ensino fundamental e foi a que mais cresceu com relação ao Ideb 2009 no segundo segmento. No entanto, ao assumir pela segunda vez o comando da prefeitura, enfrentou duas greves dos profissionais da educação, a primeira em 2013 e a segunda em 2014. Apesar da melhoria no desempenho dos alunos nas avaliações externas, no primeiro ano do segundo mandato do então prefeito, o Sindicato Estadual dos Profissionais de Educação (Sepe-RJ) defendia o direito de acesso a uma educação de qualidade para os alunos e, mais especificamente, a rede municipal reivindicava um reajuste de $19 \%$ no salário; um plano de carreira unificado; 1/3 da carga horária para planejamento; o fim da meritocracia e melhores condições de trabalho ${ }^{3}$.

Por outro lado, nesse contexto ${ }^{4}$ em que predominam os resultados das avaliações externas e as políticas de meritocracia e responsabilização docente, que espaços são encontrados para a formação cultural do aluno em espaços de educação não formal? Dentre as políticas educacionais nacionais, estaduais e municipais, àquelas voltadas para a formação cultural ainda são muito tímidas, principalmente em relação à pequena valorização do potencial apresentado pelos equipamentos culturais.

Tal constatação, num mundo tão plural e globalizado, soa como um descompasso. Em palestra proferida pelo professor Marcelo Bárcia, da Universidade Veiga de Almeida, durante a Feira de Formação Profissional de uma escola privada carioca ${ }^{5}$, acerca das dez competências para o profissional do futuro, ficou evidente que uma forte formação cultural diversificada é fundamental no mundo de trabalho atual. Um dos exemplos utilizados foi a gerência de projetos,

\footnotetext{
${ }^{3}$ Disponível em: http://www.seperj.org.br/ver_noticia.php?cod_noticia=4298. Acesso em: 28 fev. 2017.

${ }^{4}$ A pesquisa para o desenvolvimento da tese ocorreu entre os anos de 2013 e 2017. A gestão da prefeitura passou por uma alteração em janeiro de 2017, mudando também a ocupação do cargo máximo da Secretaria Municipal de Educação. Dados referentes ao atual governo não são apresentados e nem discutidos por se tratar de um tempo insuficiente para medir impactos, até mesmo porque o atual secretário de educação não conseguiu formular uma proposta sistêmica e optou por não fazer mudanças pontuais e desconexas nesses primeiros seis meses de gestão. Mais informações em: http://www.rioeduca.net/blog.php?bid=17. Acesso em: 20 jul. 2017.

${ }^{5}$ A palestra foi ministrada no mês de maio de 2017.
} 
em que pessoas de diferentes origens trabalham numa mesma empreitada. Outro exemplo citado foi o ensino proposto pela Universidade Minerva (São Francisco/EUA), que aposta em uma forte imersão global e cultural, onde os estudantes, até o momento da graduação, viajarão e viverão em sete diferentes locais ao redor do mundo.

Assim, o objetivo desta pesquisa é discutir sobre as possibilidades de formação cultural dos alunos da rede municipal de educação da cidade do Rio de Janeiro, especialmente através do contato com os equipamentos culturais parceiros da prefeitura no Projeto Escola e Museu ${ }^{6}$. A aposta é de que esse acesso pode contribuir para a ampliação da formação cultural, em uma dimensão de experiência crítica, que proporcione o desenvolvimento da emoção estética e a inserção do aluno na sociedade na perspectiva cultural. As diferentes manifestações artísticas como a literatura, a dança, a pintura, o teatro e a música não podem ser tratadas como conhecimentos secundários no currículo escolar.

Em geral, a promoção cultural se dá através do diálogo das escolas com instituições diretamente ligadas à cultura como, por exemplo, os museus, centros culturais, bibliotecas, teatros e planetários. É justamente nesse ponto que encontro uma lacuna no campo educacional: em tempos de responsabilização docente baseada em índices construídos a partir dos resultados das avaliações em larga escala, há possibilidades para a formação cultural em espaços de educação não formal? A preocupação da Secretaria Municipal de Educação do Rio de Janeiro (SME/RJ) com o rendimento escolar é maior do que a preocupação com o acesso a outras instâncias de formação cultural? Como as escolas se apropriam dos equipamentos culturais, especialmente dos museus parceiros da SME/RJ? A escola valoriza o diálogo com os espaços de educação não formal? Quais experiências os alunos da rede estão vivenciando nos equipamentos culturais?

Segundo Kramer e Carvalho (2012),

a experiência de crianças, jovens e adultos nos mais diversos espaços culturais pode atuar no sentido de informar seu olhar, sensibilizar e flexibilizar seu conhecimento e, desse modo, propiciar situações que se configuram como importantes momentos de aprendizado do ponto de vista cultural, político, ético e estético (p. 25).

\footnotetext{
${ }^{6}$ O Projeto Escola e Museu será detalhado mais adiante.
} 
As experiências que tenho vivenciado no Projeto de Pós-Graduação em Educação na PUC-Rio também contribuíram para que eu construísse novas aprendizagens. Anteriormente, até meados de 2014, a minha proposta de pesquisa era, tomando por base as iniciativas de responsabilização da atual gestão da educação municipal do Rio de Janeiro e a relevância que gestores e docentes têm no processo de ensino-aprendizagem, avaliar como as "pressões" exercidas por essa política afetam as práticas no interior das escolas ditas de alto e baixo desempenho. De modo geral, a questão que pretendia abordar era: Como a política de responsabilização docente é internalizada e quais são os efeitos que exercem nas práticas da gestão e dos docentes no interior das escolas geridas pela SME/RJ? No entanto, a oportunidade de cursar a disciplina Educação, Cultura e Museus me fez repensar e redesenhar o meu projeto de tese. As temáticas qualidade educacional, avaliação e responsabilização docente continuam presentes nesse novo desenho de pesquisa devido à relevância que as mesmas possuem no atual debate da área educacional, mas as discussões sobre cultura e espaços não formais de educação me levaram a questionar se, no contexto dessas temáticas, a Secretaria Municipal de Educação do Rio de Janeiro tem desenvolvido projetos que contemplam a formação cultural dos alunos matriculados na rede, ainda que o cenário se apresente fortemente influenciado pelos resultados das avaliações externas em contexto internacional.

Nessa transição e ampliação do meu olhar, esbarrei também na minha formação inicial, que é em ciências biológicas. Até então, em geral, enquanto professora da rede pública municipal e da rede privada de ensino, a minha abordagem com os alunos sobre a visão dos seres humanos foi definida do ponto de vista anatômico-fisiológico como algo complexo, pois existem algumas partes responsáveis por detectar a luz e outras partes responsáveis por detectar as imagens e interpretá-las. A visão funciona a partir da luz que chega aos olhos e atravessa a córnea, o humor aquoso e a pupila, e chega ao cristalino, que direciona os raios de luz até à retina, onde se forma uma imagem invertida do objeto focalizado. Nesse momento, entram em ação as células receptoras - os cones e os bastonetes - que enviam impulsos nervosos ao nervo óptico, que por sua vez os envia ao cérebro. A imagem que chega ao cérebro é então interpretada de modo que a imagem, antes invertida, seja vista na posição correta. Entretanto, no campo da educação, percebi que a visão cultural de um ser social também é complexa. 
Aliás, não se trata mais de trabalhar a visão e sim o olhar. As diferentes experiências no âmbito da cultura são incorporadas de forma contínua e permitem aos sujeitos pensar sobre si e sobre o outro, e, assim como o cérebro é capaz de interpretar e modificar a posição da imagem formada, tendo a capacidade de mudar o nosso olhar, essas experiências permitem um novo enquadramento do sujeito e do mundo, construindo novos sentidos, abrindo espaço para a ação e criação.

A inspiração também partiu dos estudos de Walter Benjamin (1994) acerca da experiência. Em “O Narrador", o autor relata que ao ouvir, contar e recontar as histórias, elas vão sendo tecidas e moldadas pelas mãos do próprio narrador, como um artesão realiza seu trabalho manual, valorizando a questão da memória para a preservação da história. O que me levou a pensar também sobre a forma como nos apropriamos do nosso patrimônio cultural.

O patrimônio cultural é um conjunto de bens culturais que estão muito presentes na história do grupo, que foram transmitidos entre várias gerações. Ou seja, são os bens culturais que ligam as pessoas aos seus pais, aos seus avós e àqueles que viveram muito tempo antes delas. São os bens que se quer transmitir às próximas gerações. (IPHAN, 2013, p. 5).

Kramer (2000) defende que a experiência com a produção cultural contribui na formação de crianças, jovens e adultos, pois pode resgatar trajetórias e relatos, provocar a discussão de valores, crenças e a reflexão crítica da cultura que produzimos e que nos produz, suscita o repensar do sentido da vida, da sociedade contemporânea e, nela, do papel de cada um. Assim, os alunos podem aprender com a cultura e com a arte para que todos tenham acesso aos conhecimentos produzidos, favorecendo a construção da identidade e de valores, além de propiciar a capacidade de narrar as experiências vividas.

Assumindo a perspectiva de Vigotsky (2009), apresentada em seu livro Imaginação e criação na infância, a capacidade criativa depende profundamente da riqueza e da diversidade de experiências porque as mesmas se configurarão como fontes primárias para a imaginação. Desse modo, tanto a prática pedagógica quanto a que é realizada nos equipamentos culturais - no contexto da investigação aqui apresentada, em parceria com a prefeitura -, podem fazer diferença na formação cultural do aluno, desde que possibilitem ampliar o repertório de experiências significativas. 
Nessa perspectiva, investiguei as ações do Projeto Escola e Museu desenvolvido pela prefeitura do Rio de Janeiro, durante o ano de 2015, através de observação das visitas dos alunos aos museus e centros culturais parceiros do referido Projeto e entrevistas com os docentes das escolas participantes, com o intuito de conhecer a proposta e verificar se a iniciativa promove uma formação cultural de qualidade.

A seguir, apresento os objetivos, questões de pesquisa, hipóteses de trabalho e justificativa.

De acordo com a Lei $\mathrm{n}^{\circ} 11.904$, de 14 de janeiro de 2009, Capítulo I, artigo $1^{\circ}$, que instituiu o Estatuto de Museus,

"Consideram-se museus, para os efeitos desta Lei, as instituições sem fins lucrativos que conservam, investigam, comunicam, interpretam e expõem, para fins de preservação, estudo, pesquisa, educação, contemplação e turismo, conjuntos e coleções de valor histórico, artístico, científico, técnico ou de qualquer outra natureza cultural, abertas ao público, a serviço da sociedade e de seu desenvolvimento".

Trilla (1985, p. 24) afirma que os meios educacionais não formais, como os museus e centros culturais, podem cobrir uma ampla gama de funções relacionadas com a educação permanente e com outras dimensões do processo educacional global, marginalizadas ou pouco assumidas pela instituição escolar. Dessa forma, considero que os equipamentos culturais, e já recortando para os que atuam em parceria com a prefeitura, configuram-se como espaços de educação não formal que apresentam o potencial de dialogar com as ações escolares e podem ser espaços em que alunos e professores usufruam de manifestações culturais, novas ferramentas de aprendizagem e, inclusive, de lazer.

Reforçando essa ideia, menciono a pesquisa de doutorado de Cazelli (2005), na qual a autora afirma, com base nos resultados encontrados, o quanto, para os alunos pertencentes à rede municipal, a escola é um contexto fundamental não só para promover o acesso, mas para garantir um maior número de museus visitados. Para os alunos da rede privada, a família costuma atuar de forma mais marcante, garantindo o acesso a distintas instituições culturais. Vale destacar que o número médio de museus visitados pelas escolas municipais, tanto de baixo quanto de alto nível socioeconômico, é maior que o número médio de museus visitados pelas escolas da rede privada de nível socioeconômico baixo. Investigando a relação escola e museu/ centro cultural, a pesquisa realizada por 
Carvalho (2005) reitera os achados de Cazelli. Além disto, Carvalho (2007) apresenta que estudos no campo artístico, museal, educacional e cultural têm demonstrado que os docentes se apresentam como a categoria profissional que mais frequenta esses espaços, bem como os grandes responsáveis pelas visitas realizadas por seus alunos.

No entanto, na tentativa de alcançar as metas propostas e os incentivos atrelados aos resultados das avaliações em larga escala (Prova Brasil e Prova Rio), um questionamento surgiu: estariam as escolas e a Secretaria Municipal de Educação priorizando práticas voltadas para o aumento do desempenho dos alunos nas disciplinas avaliadas e reduzindo o tempo destinado aos objetivos escolares que não são aferidos nos exames como, por exemplo, as práticas culturais e visitas aos espaços não formais de educação?

Nesta perspectiva, o presente estudo tem como objetivo geral conhecer a qualidade da formação cultural dos alunos matriculados no segundo segmento das escolas da rede municipal do Rio de Janeiro em tempos de responsabilização docente, através do acesso desses adolescentes a sete equipamentos culturais que atuam em parceria com a Secretaria Municipal de Educação do Rio de Janeiro (SME/RJ), por meio do Projeto Escola Museu, que será explicitado mais adiante. Pretende-se compreender a política construída, através das ações do Projeto Escola e Museu, acerca da formação cultural e investigar a qualidade do atendimento que é ofertado em tais espaços. Até que ponto as escolas conseguem viabilizar visitas aos museus e centros culturais parceiros da prefeitura? Esses espaços fazem parte do cotidiano escolar? Conseguem atender às demandas das escolas da rede municipal?

Do foco central da pesquisa, destaca-se alguns objetivos específicos: entender a perspectiva do setor da Secretaria Municipal de Educação responsável pelas ações culturais; elucidar as políticas de formação cultural da prefeitura, em especial, o Projeto Escola e Museu ${ }^{7}$; construir um mapa da distribuição dos equipamentos culturais com o intuito de compreender como essa distribuição pode favorecer ou dificultar o acesso aos bens culturais; identificar os padrões de acesso das escolas do segundo segmento do ensino fundamental, foco do Projeto

\footnotetext{
${ }^{7}$ A ênfase será dada aos museus, fundações e centros culturais, já que esses espaços são priorizados pela SME e pela pesquisa atual do Grupo de Pesquisa Educação, Museu, Cultura e Infância (GEPEMCI - CNPq/PUC-Rio), do qual sou integrante.
} 
Escola e Museu, aos espaços culturais parceiros da SME/RJ e perceber a qualidade do que é ofertado nos museus e centros culturais aos alunos desse segmento matriculados nas escolas pertencentes à rede municipal de ensino, buscando abarcar compreender o tipo de experiências que esses estudantes constroem.

No que diz respeito às questões e etapas da pesquisa, a questão principal aqui desenvolvida é a identificação dos padrões de acesso das escolas do segundo segmento do ensino fundamental aos espaços culturais do Projeto Escola e Museu e a percepção da qualidade do atendimento que é ofertado: De que forma se dá o acolhimento a esses alunos? Qual é a sua dinâmica? Que experiências estão sendo proporcionadas? As iniciativas desenvolvidas nesses espaços estimulam o pensamento de modo a ampliar o repertório para uma ação crítica e criativa a partir da formação cultural? Qual é a percepção dos professores participantes do Projeto?

Objetivando viabilizar a pesquisa, foram desenvolvidas três etapas:

1. Para conhecer a perspectiva do setor da Secretaria Municipal de Educação responsável pelas ações culturais

Qual é o setor responsável pelas ações culturais promovidas pela Secretaria Municipal de Educação? Quem coordena essa equipe? Como são pensadas as iniciativas? Que autores orientam os projetos desenvolvidos? As visitas aos espaços de educação não formal estão previstas em documentos oficiais da Secretaria Municipal de Educação?

2. Para a elucidação das políticas de formação cultural da prefeitura, em especial, o Projeto Escola e Museu

Como foi elaborado esse Projeto? Como se deu a escolha das sete instituições culturais parceiras: Centro Cultural Banco do Brasil (CCBB/RJ), Centro Cultural do Poder Judiciário (CCPJ), Centro Municipal de Arte Hélio Oiticica, Espaço Oi Futuro (Flamengo), Fundação Eva Klabin, Museu de Arte do Rio (MAR) e Museu Nacional da Universidade Federal do Rio de Janeiro? Há um setor responsável pela realização do projeto nestes equipamentos culturais? 
Que tipo de proposta é desenvolvida? As atividades desenvolvidas promovem uma formação cultural de qualidade?

3. Para a construção de um mapa da distribuição dos equipamentos culturais e compreensão sobre o modo como essa distribuição pode favorecer ou dificultar o acesso aos bens culturais

Como estão distribuídos os museus, centros culturais e planetários municipais pela cidade do Rio de Janeiro? Como se dá a relação oferta e demanda entre as escolas e os espaços culturais? A quantidade de equipamentos culturais da Secretaria Municipal de Cultura comporta o número de alunos matriculados na rede? A escolha das instituições parceiras reforça ou diminui a desigualdade na distribuição territorial dos equipamentos culturais? Onde estão localizadas os museus e centros culturais parceiros?

Durante a sistematização da pesquisa, trabalhou-se com quatro hipóteses:

1. As ações da Secretaria Municipal de Educação do Rio de Janeiro voltadas para a formação cultural ainda são tímidas frente às preocupações com a formação acadêmica divulgada à sociedade através dos resultados em avaliações externas.

2. O Projeto Escola e Museu atende a um número reduzido de escolas e reforça a ideia de que para ter acesso à cultura é preciso integrar-se aos equipamentos localizados, principalmente, nas regiões do Centro e Zona Sul da cidade do Rio de Janeiro.

3. A prefeitura do Rio de Janeiro reforça a distribuição desigual dos equipamentos culturais com as obras atuais de construção de museus.

4. As experiências proporcionadas nos museus e centros culturais são muito diferentes em termos de qualidade, ainda que todos estejam ligados ao Projeto Escola e Museu.

A opção pela rede municipal de educação do Rio de Janeiro está ligada à representatividade da mesma no contexto nacional e internacional, pois se configura como a maior Rede Pública Municipal de Ensino da América Latina, atualmente dividida em 11 Coordenadorias Regionais de Educação (tabela 1). 
De acordo com a SME/RJ são: 11 Coordenadorias Regionais de Educação, 1.534 unidades escolares, divididas em 1.016 escolas de Ensino Fundamental e 518 unidades de Educação Infantil, configurando um total geral de 641.655 alunos matriculados, sendo 59.776 alunos de creches, 83.108 alunos na pré-escola e 498,771 no ensino fundamental, atendidos por 41.302 professores (14.337 professores I, 16.827 professores II, 4.994 professores de ensino fundamental e 5.144 professores de educação infantil), 5.501 agentes de Educação Infantil, 1.099 secretários escolares e 15.191 funcionários de apoio administrativo ${ }^{8}$.

Tabela 1: Distribuição das escolas por divisão das CREs

\begin{tabular}{|c|c|c|}
\hline CRE & $\begin{array}{c}\text { Total de } \\
\text { escolas }\end{array}$ & Área de abrangência \\
\hline 1 & 96 & $\begin{array}{l}\text { Santo Cristo. Catumbi. Centro. Saúde. São Cristóvão. Caju. Estácio. Bairro de } \\
\text { Fátima. Mangueira. Praça Onze. Rio Comprido. Santa Teresa - Morro dos } \\
\text { Prazeres. Santa Teresa. Cidade Nova. Rio Comprido - Turano. Mangueira - } \\
\text { Morro dos Telégrafos. Vasco da Gama. Gamboa. Benfica. São Cristóvão - } \\
\text { Tuiuti. Paquetá. Santa Tereza. Praça Mauá. }\end{array}$ \\
\hline 2 & 150 & $\begin{array}{l}\text { Jardim Botânico. Catete. Praia Vermelha. Usina. Copacabana - Morro dos } \\
\text { Cabritos. Rio Comprido. Tijuca - Comunidade Chacrinha. Laranjeiras. Tijuca } \\
\text { - Andaraí. Tijuca. Grajaú - Morro Nova Divinéia. Glória. Alto da Boa Vista. } \\
\text { Alto Boa Vista. Andaraí. Praça Da Bandeira. Grajaú. Cosme Velho. Lagoa. } \\
\text { Urca. Flamengo. Vidigal. Leblon. Andaraí - Jamelão. Vila Isabel. Rocinha. } \\
\text { Andaraí - Morro do Andaraí. Botafogo. Ipanema. Praça da Bandeira. São } \\
\text { Conrado. Leme. Humaitá. Gávea. Maracanã. Copacabana. }\end{array}$ \\
\hline 3 & 132 & $\begin{array}{l}\text { Engenho da Rainha. Tomáz Coelho. Riachuelo. Encantado. Abolição. Maria } \\
\text { da Graça. Engenho Da Rainha. Jacarezinho. Engenho De Dentro. Sampaio. } \\
\text { Rocha. Engenho da Rainha. Jacaré. Piedade. Ramos. Bonsucesso. Engenho } \\
\text { Novo. Complexo do Alemão - Ramos. Bonsucesso - Complexo do Alemão. } \\
\text { Largo do Jacaré. Água Santa. Cachambi. Méier. Tomás Coelho. Todos os } \\
\text { Santos. Engenho de Dentro. Higienópolis. Pilares. Inhaúma. Lins de } \\
\text { Vasconcelos. Triagem. Del Castilho. }\end{array}$ \\
\hline 4 & 148 & $\begin{array}{l}\text { BONSUCESSO. Bonsucesso - Maré. PENHA. Vila do João / Maré. Praça Do } \\
\text { Carmo/Penha. Ramos. Vigário Geral. Olaria. Benfica. Ilha do Governador. } \\
\text { Manguinhos. Jardim América. Vila Da Penha. Manguinhos - Bonsucesso. } \\
\text { Cordovil. Bonsucesso. Penha Circular. Penha. Penha Circular. Bonsucesso } \\
\text { (Maré ). Brás de Pina. Parada de Lucas. }\end{array}$ \\
\hline 5 & 130 & $\begin{array}{l}\text { Vila Kosmos. Bento Ribeiro. Cascadura. Vicente de Carvalho. Honório } \\
\text { Gurgel. Vila Da Penha. Rocha Miranda. Marechal Hermes. Osvaldo Cruz. } \\
\text { Cavalcante. Turiaçu. Campinho. Vaz Lobo. Vista Alegre. Irajá. Colégio. } \\
\text { Madureira. Quintino Bocaiúva. }\end{array}$ \\
\hline 6 & 106 & $\begin{array}{l}\text { Conj. Hab. Amarelinho - Irajá. Caminho do Job - Pavuna. Deodoro. Barros } \\
\text { Filho. Ricardo de Albuquerque. Jardim Cristina Capri - Anchieta. Irajá. } \\
\text { Parque Anchieta. Pavuna. Coelho Neto. Costa Barros. Acari. Anchieta. } \\
\text { Guadalupe. }\end{array}$ \\
\hline 7 & 164 & $\begin{array}{l}\text { Anil. Gardênia Azul. Anil-Jacarepaguá. Camorim. Pechincha. Itanhangá. } \\
\text { Curicica. Recreio. Rio das Pedras. Recreio dos Bandeirantes. Vargem Grande. } \\
\text { Cidade de Deus. Vargem Pequena. Jacarepaguá. Taquara. Rio das Pedras - } \\
\text { Jacarepaguá. RIO DAS PEDRAS. Vila Valqueire. Tanque. Freguesia. } \\
\text { CIDADE DE DEUS. Praça Seca. Jacarepaguá - Taquara. Cidade De Deus. } \\
\text { Barra da Tijuca. Rio Das Pedras. -ITANHANGÁ. }\end{array}$ \\
\hline
\end{tabular}

\footnotetext{
${ }^{8}$ Disponível em: http://www.rio.rj.gov.br/web/smeel/educacao-em-numeros. Acesso em: 28 fev. 2017.
} 


\begin{tabular}{|c|c|c|}
\hline 8 & 183 & $\begin{array}{l}\text { Jardim Sulacap. BANGU. Magalhães Bastos. Padre Miguel. Bangu. G. Da } \\
\text { Silveira. Senador Camará. Vila Kennedy. Senador Camará . Sulacap. } \\
\text { Santíssimo. Vila Militar. PADRE MIGUEL. Deodoro. Jabour. Guadalupe. } \\
\text { Realengo. }\end{array}$ \\
\hline 9 & 141 & $\begin{array}{l}\text { Carobinha-Campo Grande. Campo Grande/ Monteiro. Inhoaiba/. Campo } \\
\text { Grande/Loteamento Joari. Campo Grande/Benjamin Dumont. Inhoaiba. } \\
\text { Campo Grande. Campo Grande / Centro. Campo Grande/Centro. } \\
\text { Cosmos/Santa Margarida. Inhoaíba/ Dumont. Campo Grande/Cachamorra. } \\
\text { Inhoaíba. COSMOS. Nova Iguaçu. Inhoaíba. Cosmos. Senador Vasconcelos. } \\
\text { Inhoaíba - Campo Grande. Campo Grande/Posse. Campo Grande/Dumont. } \\
\text { Campo Grande /Monteiro. Campo Grande. Santíssimo. }\end{array}$ \\
\hline 10 & 165 & $\begin{array}{l}\text { SANTA CRUZ. Sepetiba. Guaratiba. Cosmos. PEDRA DE GUARATIBA. } \\
\text { PACIÊNCIA. Ilha De Guaratiba. Paciência. Barra De Guaratiba. Santa Cruz. } \\
\text { Jardim dos Vieiras, Paciência. Pedra de Guaratiba. S. Fernando Santa Cruz. }\end{array}$ \\
\hline 11 & 42 & $\begin{array}{l}\text { Tauá. ILHA DO GOVERNADOR. Galeão. Praça da Bandeira. Freguesia. Ilha } \\
\text { do Governador. Itacolomi. Tubiacanga. Pitangueiras. Cocotá. Moneró. } \\
\text { Portuguesa. J. Guanabara. Bancários - Ilha do Governador. C. Universitária. } \\
\text { Guarabu. Zumbi. Bancários. J. Carioca. }\end{array}$ \\
\hline
\end{tabular}

Fonte: Elaboração própria.

As CREs são heterogêneas entre si em vários aspectos: número de escolas, quantitativo de alunos atendidos, tamanho da área de abrangência e também no Índice de Desenvolvimento Social (IDS). No município do Rio de Janeiro há áreas com maior concentração de riquezas e outras menos, e essa heterogeneidade permanece entre as escolas de uma mesma CRE, ou seja, há escolas com IDS maiores e menores do que o da CRE em que estão inseridas. Assim, há uma forte estratificação territorial e educacional que não deveria ser desconsiderada pelos gestores no momento de alocar agentes e recursos às escolas.

Em seu estudo, Cazelli (2010), identifica o quanto a cidade do Rio de Janeiro, apesar de ser um dos mais importantes centros culturais do Brasil, não fornece acesso à cultura de maneira equânime para seus habitantes. Os museus, centros culturais, teatros, cinemas e bibliotecas estão quase todos localizados em poucas áreas da cidade, como Centro, São Cristóvão, Zona Sul, Tijuca, Vila Isabel e Barra. A partir dessa informação, investiguei a distribuição espacial dos equipamentos culturais da prefeitura do Rio de Janeiro e foi possível constatar que o poder público também reproduz a desigualdade na oferta cultural. A tabela 2 e o anexo $\mathrm{I}^{9}$ explicitam a distribuição dos aparelhos culturais por Coordenadorias Regionais de Educação.

\footnotetext{
${ }^{9} \mathrm{O}$ anexo I inclui o nome dos equipamentos culturais.
} 
Tabela 2: Distribuição dos equipamentos culturais pertencentes à prefeitura do Rio de Janeiro por CRE.

\begin{tabular}{|c|c|}
\hline CRE & Quantidade e tipo de equipamento cultural \\
\hline $\mathbf{1}^{\mathbf{a}}$ & $\begin{array}{l}1 \text { biblioteca popular, } 2 \text { espaços de leitura, } 5 \text { centros culturais, } 3 \\
\text { museus, } 2 \text { teatros }\end{array}$ \\
\hline $2^{\mathbf{a}}$ & $\begin{array}{l}2 \text { bibliotecas populares, } 4 \text { centros culturais, } 2 \text { museus, } 1 \text { planetário, } \\
7 \text { teatros e } 2 \text { teatros de Guignol }\end{array}$ \\
\hline $3^{\mathbf{a}}$ & 1 centro cultural e 1 teatro de Guignol \\
\hline $4^{\mathrm{a}}$ & 1 espaço de leitura, 1 arena e 2 lonas culturais \\
\hline $5^{\mathbf{a}}$ & 1 arena, 1 biblioteca popular e 1 espaço de leitura \\
\hline $\mathbf{6}^{\mathbf{a}}$ & 1 arena e 2 lonas culturais \\
\hline $7^{\mathbf{a}}$ & 1 biblioteca popular, 1 centro cultural e 1 lona cultural \\
\hline $8^{\mathbf{a}}$ & 2 lonas culturais \\
\hline $9^{\mathbf{a}}$ & 1 biblioteca popular e 1 lona cultural \\
\hline $10^{\mathbf{a}}$ & 1 arena, 1 espaço de leitura, 1 lona cultural e 1 planetário \\
\hline $11^{\mathbf{a} 10}$ & 1 biblioteca popular e 1 lona cultural \\
\hline
\end{tabular}

Fonte: Elaboração própria.

É possível notar que há uma concentração de equipamentos culturais da prefeitura nas regiões da $1^{\mathrm{a}}$ e $2^{\mathrm{a}}$ CREs, ou seja, as escolas pertencentes a essas CREs estão localizadas em regiões mais favorecidas do ponto de vista socioeconômico e cultural e são as mesmas que dispõem de mais oferta cultural proporcionada pela prefeitura (mapa 1 e tabela 3). Essa constatação é preocupante, já que reforça a desigualdade entre as escolas da rede também no que diz respeito à possibilidade de acesso aos bens culturais.

Cabe ressaltar que apenas a proximidade aos equipamentos culturais não garante a frequência. Os museus, centros culturais, teatros, cinemas, planetários, bibliotecas e outras instâncias culturais precisam ser apresentadas às crianças e adolescentes. Como dito anteriormente, no caso dos alunos pertencentes à rede municipal do Rio de Janeiro, as escolas fazem diferença nessa aproximação entre os alunos e os espaços de educação não formal. No entanto, se a escola não tiver essa percepção e não valorizar esse tipo de ação, de nada adiantará estar em uma localização privilegiada, repleta de opções culturais. Vale também lembrar que as instituições de ensino responsáveis pela formação de docentes precisam incluir tal discussão na pauta de formação para que futuros professores entendam a relevância das experiências culturais na vida dos alunos. Não menos importante,

\footnotetext{
${ }^{10}$ A $11^{\text {a }}$ CRE não existia, pois era parte da $4^{\mathrm{a}} \mathrm{CRE}$.
} 
também é papel das redes municipais, estaduais e federais o incentivo e a promoção das visitas escolares aos equipamentos culturais.

Mapa 1: Distribuição dos equipamentos culturais pertencentes à prefeitura do Rio de Janeiro por CRE.

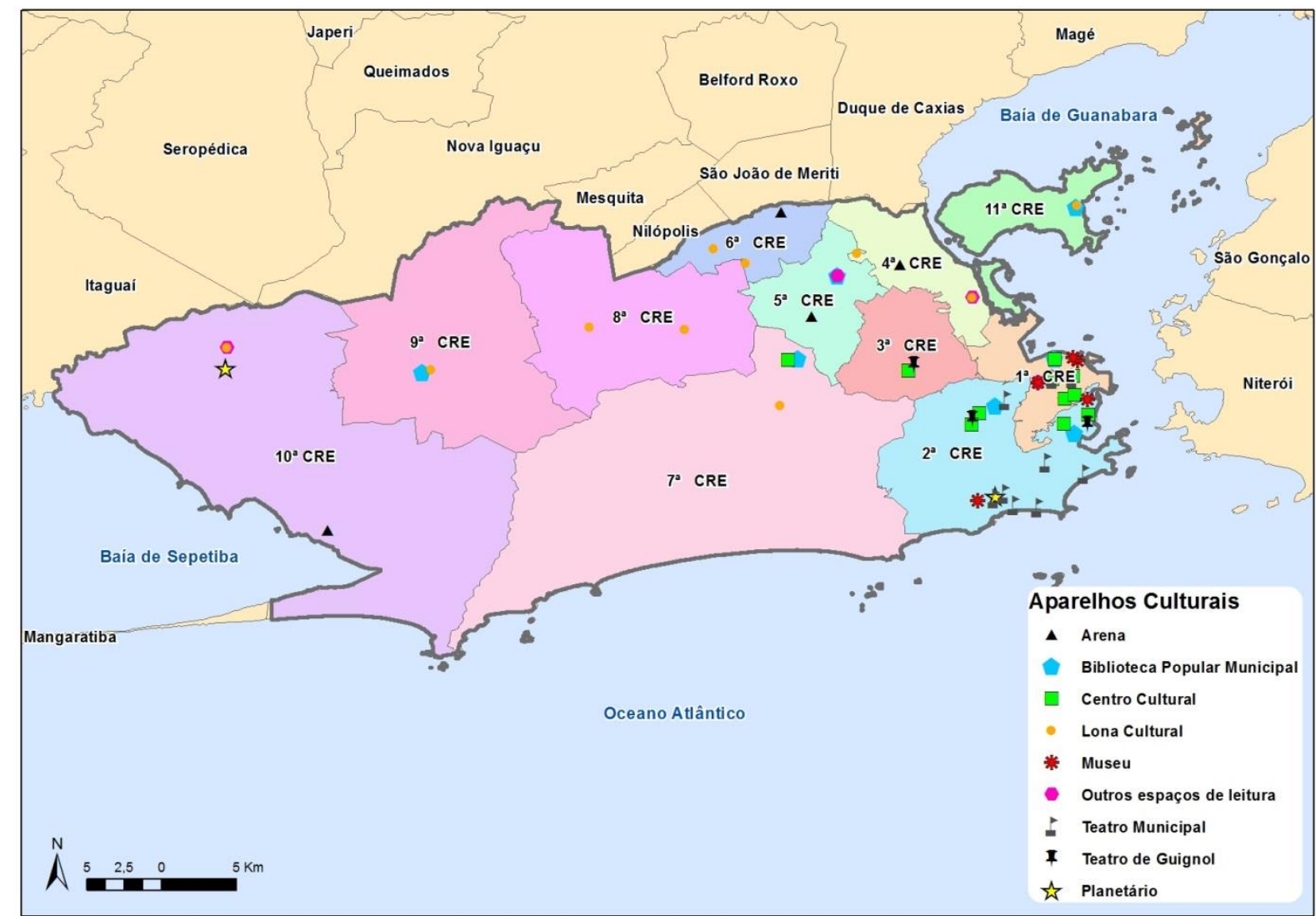

Fonte: Elaboração própria (2015).

Tabela 3: Quantitativo de alunos do ensino fundamental, escolas e aparelhos culturais da prefeitura por CRE

\begin{tabular}{cccccc}
\hline CRE & $\begin{array}{c}\text { Total de } \\
\text { alunos do } \\
\text { Ensino } \\
\text { Fundamental }\end{array}$ & $\begin{array}{c}\text { Alunos do } \\
\mathbf{1}^{\mathbf{o}}\end{array}$ & $\begin{array}{c}\text { Alunos do } \\
\mathbf{2}^{\mathbf{o}} \\
\text { segmento }\end{array}$ & $\begin{array}{c}\text { Total de } \\
\text { segmento } \\
\text { Encolas de } \\
\text { Ensino } \\
\text { Fundamental }\end{array}$ & $\begin{array}{c}\text { Total de } \\
\text { aparelhos } \\
\text { culturais da } \\
\text { prefeitura }\end{array}$ \\
\hline $\mathbf{1}^{\mathbf{a}}$ & 21135 & 11583 & 9552 & 64 & 13 \\
\hline $\mathbf{2}^{\mathbf{a}}$ & 37432 & 19943 & 17489 & 147 & 18 \\
\hline $\mathbf{3}^{\mathbf{a}}$ & 39466 & 21144 & 18322 & 117 & 2 \\
\hline $\mathbf{4}^{\mathbf{a}}$ & 53754 & 29057 & 24697 & 141 & 4 \\
\hline $\mathbf{5}^{\mathbf{a}}$ & 42910 & 21767 & 21143 & 133 & 3 \\
\hline $\mathbf{6}^{\mathbf{a}}$ & 31580 & 17415 & 14165 & 86 & 3 \\
\hline $\mathbf{7}^{\mathbf{a}}$ & 64475 & 35266 & 29209 & 156 & 3 \\
\hline $\mathbf{8}^{\mathbf{a}}$ & 57619 & 30064 & 27555 & 176 & 2 \\
\hline
\end{tabular}




\begin{tabular}{cccccc}
\hline $\mathbf{9}^{\mathbf{a}}$ & 53722 & 27606 & 26116 & 141 & 2 \\
\hline $\mathbf{1 0}^{\mathbf{a}}$ & 66973 & 35243 & 31730 & 146 & 4 \\
\hline $\mathbf{1 1}^{\mathbf{a}}$ & 12305 & 6474 & 5831 & 51 & 2
\end{tabular}

Fonte: Elaboração própria a partir dos dados do Censo 2015

Justificando ainda a escolha pela temática das diferentes dimensões da qualidade educacional, defendendo que são necessárias evidências empíricas para uma real avaliação das políticas públicas acerca da qualidade da formação dos alunos, pois considero que as mesmas trazem mudanças para o interior das escolas e geram diferentes formas de apropriação. Conhecer os efeitos pode interferir nos rumos das políticas, possibilitando ajustes para aprimorá-las.

As políticas culturais públicas deveriam estar voltadas para a redução das desigualdades, viabilizando a possibilidade de acesso aos equipamentos culturais de modo equânime entre as escolas da rede. E não estou aqui defendendo uma única perspectiva, pois, conforme destaca Trilla (1985, p. 143), a educação não formal pode ser tão classista, alienante, burocrática, ineficaz, onerosa, obsoleta, manipuladora, estereotipada e uniformizadora quanto a formal.

Além disso, essa é uma das primeiras pesquisas que abordará duas dimensões do conceito de qualidade - a acadêmica e a cultural - por meio do acesso aos equipamentos culturais parceiros da SME/RJ no Projeto Escola e Museu, envolvendo as escolas da rede municipal do Rio de Janeiro em um contexto de responsabilização docente.

Quanto aos aspectos metodológicos, a pesquisa aqui apresentada segue alguns procedimentos, no sentido de conferir maior rigor e validade ao trabalho. É possível dividir o processo em três grandes fases: i) exploratória, caracterizada pela delimitação do estudo, pela busca do referencial teórico e pela construção do projeto de pesquisa; ii) realização do trabalho de campo, caracterizada pela produção dos dados; iii) análise, que visa a compreensão dos dados produzidos a partir dos pressupostos teóricos.

Todas as etapas da pesquisa são valiosas porque sem um bom plano podese gerar gasto de tempo e recursos desnecessários, tão precisos na produção acadêmica. Portanto, nesse momento, dedico-me às questões metodológicas.

A primeira etapa realizada para o desenvolvimento desta pesquisa foi o aprofundamento da revisão de literatura acerca da qualidade educacional, tanto em 
sua dimensão acadêmica quanto cultural. Para tanto, foi realizada uma busca em bases acadêmicas por artigos, dissertações e teses que abordassem a temática. A realização de estados da arte tem papel fundamental no processo acadêmico, já que viabiliza a construção de um balanço da pesquisa de uma determinada área e, através dela, é possível situar o próprio trabalho dentro do campo educacional, contextualizando e problematizando aspectos do trabalho a ser desenvolvido.

Segundo Brandão (2001), justamente nessa fase da pesquisa é que pode surgir a originalidade de cada autor, percebendo até que ponto os pesquisadores anteriores conseguiram alcançar a temática, identificar as lacunas existentes e os silêncios para entender o que já foi produzido na área e qual será a contribuição a ser feita, evitando uma produção repetida ou muito semelhante a algo que já foi trabalhado, porque ajuda a distinguir o que já foi feito do que precisa ser investigado. A revisão fornece subsídio ao pesquisador para que o mesmo se intere mais sobre os termos/nomenclatura de uma área e potencializa a orientação, facilitando a escolha do caminho a trilhar de modo consciente e auxiliando, inclusive, na definição do problema até à interpretação dos dados produzidos. Uma nova investigação abre portas para complementar ou contestar contribuições anteriores. Brandão (2001) relata que

A verdade de hoje é a dúvida de amanhã e os "achados" científicos exigem, cada vez mais, um processo permanente de problematização e superação. A verdade perdeu o caráter permanente de outros tempos e é, com frequência, operada do ângulo da verdade como processo. (p. 63).

Concordando com Zago (2003), a regra das pesquisas é respeitar princípios éticos e de objetividade, bem como garantir as condições que favoreçam uma melhor aproximação da realidade social estudada, pois nenhum método dá conta de captar o problema em todas as suas dimensões. Portanto, é aconselhável integrar diferentes abordagens metodológicas: (i) entrevistas (estruturadas, semiestruturadas, informais) - é importante estabelecer uma relação de confiança com o entrevistado, deve-se pensar no número de entrevistas, no local mais apropriado para a realização das mesmas, na duração de cada uma, fazer um pré-teste do roteiro, refletir sobre a quantidade e a relevância das perguntas, e entender a entrevista não como uma coleta de dados mecânica, mas como uma produção de dados, já que o tipo de pergunta exige um padrão de 
resposta, logo, dependendo da pergunta, mudam os dados da pesquisa; (ii) questionários; (iii) análise de documentos etc.

Tendo em vista os objetivos propostos nesta pesquisa, optou-se por uma abordagem qualitativa, largamente utilizada em pesquisas da área educacional, fazendo uso de alguns instrumentos metodológicos, como a análise de documentos, a observação das atividades desenvolvidas no Projeto Escola e Museu e entrevistas semiestruturadas com os docentes participantes. Para conhecer a perspectiva do setor da Secretaria Municipal de Educação responsável pelas ações culturais, fiz a opção pelo recurso da entrevista estruturada.

Cada uma dessas metodologias foi escolhida para compor uma triangulação, ou seja, compreender o objeto por diferentes ângulos. Segundo Vianna (2003), a técnica de triangulação é uma aliada, pois muitas vezes os sujeitos da pesquisa podem ter seu comportamento e/ou discurso influenciados pela presença do pesquisador, acarretando em falas que visam a responder o que acreditam ser o esperado pelo pesquisador. $\mathrm{O}$ cruzamento dos dados, bem como o uso de diversas teorias pode proporcionar um maior nível de confiabilidade e de compreensão, tornando a pesquisa mais consistente.

As entrevistas permitem entender a lógica que preside as relações de grupo, desde que seja feita uma boa entrevista e, nesta perspectiva, Duarte (2004) afirma que esse processo exige:

a) que o pesquisador tenha muito bem definidos os objetivos de sua pesquisa (e introjetados — não é suficiente que eles estejam bem definidos apenas "no papel"); b) que ele conheça, com alguma profundidade, o contexto em que pretende realizar sua investigação (a experiência pessoal, conversas com pessoas que participam daquele universo - egos focais/informantes privilegiados -, leitura de estudos precedentes e uma cuidadosa revisão bibliográfica são requisitos fundamentais para a entrada do pesquisador no campo); c) a introjeção, pelo entrevistador, do roteiro da entrevista (fazer uma entrevista "não-válida" com o roteiro é fundamental para evitar "engasgos" no momento da realização das entrevistas válidas); d) segurança e auto-confiança; e) algum nível de informalidade, sem jamais perder de vista os objetivos que levaram a buscar aquele sujeito específico como fonte de material empírico para sua investigação. (p. 216).

Alguns cuidados metodológicos precisam ser tomados quando se deseja realizar uma entrevista. Para Duarte (2004), quando a fala e/ou história de um possível sujeito de pesquisa se apresentarem facilmente reconhecidas, a entrevista deve ser evitada para não quebrar a garantia do anonimato. Locais que passam por situações de crise como, por exemplo, disputas de poder pelo cargo de direção 
escolar, também devem ser evitados para não expor os sujeitos e nem enviesar a pesquisa pelo clima da situação. Outro cuidado, não menos importante, é que o pesquisador não deve perder de vista que é ele quem define os rumos da pesquisa e não o informante e nem tudo que o observante fala cabe aos objetivos da pesquisa.

É fundamental manter durante toda a pesquisa o exercício da consciência da nossa subjetividade para não deixar que a mesma prejudique a análise. É preciso olhar a entrevista dentro dela mesma, buscando o sentido da fala daquele indivíduo, mas também buscar a relação com outras variáveis, construindo um sentido coletivo. Durante todo esse processo, o material empírico produzido deve ser lido à luz da literatura científica de referência para que haja um movimento de articulação entre a teoria e a prática, sem que uma se feche na outra, potencializando o poder de explicitação dos fenômenos educacionais, e deixando emergir o novo.

De modo complementar, também foi realizada uma análise documental, possibilitando, assim, a elucidação das políticas de formação cultural da prefeitura, em especial, o Projeto Escola e Museu. Em sites oficiais da rede municipal de educação estão disponíveis informações sobre tais políticas e seus desdobramentos.

Para a construção de um mapa da distribuição dos equipamentos culturais e das escolas participantes do Projeto Escola e Museu, de um modo que facilitasse a compreensão de como essa distribuição pode favorecer ou dificultar o acesso aos bens culturais, foi utilizada a divisão por CREs para situar esses equipamentos geograficamente. Na tentativa de estabelecer uma relação entre a oferta cultural e a demanda, esses achados foram cruzados com os dados sobre matrícula no segundo segmento do Ensino Fundamental, disponibilizados pela ferramenta educacional Latitude.

Buscando identificar os padrões de acesso aos espaços culturais das vinte e duas escolas do segundo segmento do ensino fundamental participantes do Projeto Escola e Museu (tabela 4) e a qualidade do que é ofertado, foram realizadas observações das visitas das escolas participantes aos equipamentos culturais parceiros da SME/RJ, entre os meses de agosto e outubro de 2015. Ao final das 
observações, foram também realizadas entrevistas com os docentes ${ }^{11}$ na tentativa de identificar qual é a percepção que apresentam sobre a recepção proporcionada aos alunos da rede municipal, na perspectiva da formação cultural de qualidade, e o sentido da experiência vivenciada ${ }^{12}$ (tabela 5). Nesta etapa, tendo em vista que muitas atividades ocorreriam de modo simultâneo, contei com a participação de integrantes do grupo de pesquisa do qual faço parte $\left(\mathrm{GEPEMCI}^{13}\right)$, estratégia que será aprofundada mais adiante.

De modo complementar, foram feitas anotações no caderno de campo, contemplando aspectos como, por exemplo, o acolhimento e a reação dos alunos, a interação dos mesmos com os mediadores, com os docentes e com os objetos expostos. A análise dos acontecimentos ali relatados com o aporte teórico é um exercício que pode articular dois eventos isolados, auxiliando na percepção de recorrências e no entendimento de fenômeno. Vianna (2003) enfatiza a relevância do relato de observações com o maior nível possível de detalhamento, apontando quando, onde, como, com quem e o que ocorreu, possibilitando a construção de um retrato da realidade observada.

Ademais, são relatadas sínteses expostas por docentes e alunos participantes do Projeto durante o III Seminário Conexões Escola e Museu, evento de culminância do Projeto, em novembro de 2015, no Espaço Oi Futuro, localizado em Ipanema, zona sul da cidade do Rio de Janeiro.

A seguir, apresento as tabelas com o quantitativo de unidades escolares participantes por CRE e de observações e entrevistas realizadas em cada instituição:

\footnotetext{
${ }^{11}$ Não foi feita a apresentação do perfil docente, já que se tratava de um grupo pequeno de professores e isto poderia facilitar a identificação dos participantes, comprometendo o sigilo.

${ }^{12}$ Os roteiros de observação e entrevista e o termo de consentimento livre e esclarecido encontram-se nos apêndices (2, 3 e 4).

${ }^{13}$ O Grupo de Pesquisa em Educação, Museu, Cultura e Infância (GEPEMCI) tem se dedicado a investigar alguns Setores Educativos de Museus e Centros Culturais da cidade do Rio de Janeiro com o intuito de mapear e conhecer as atividades oferecidas ao público em geral - e mais especificamente às crianças de 0 a 6 anos -, a estrutura de funcionamento mantida pelas instituições, os agentes sociais que neles atuam e, principalmente, as estratégias pedagógicas desenvolvidas nesses espaços.
} 
Tabela 4: Quantitativo de Unidades Escolares participantes por CRE

CRE Quantidade de Unidades

Escolares participantes

\begin{tabular}{cc}
\hline $\mathbf{1}^{\mathbf{a}}$ & 2 \\
\hline $\mathbf{2}^{\mathbf{a}}$ & 2 \\
$\mathbf{3}^{\mathbf{a}}$ & 1 \\
\hline $\mathbf{4}^{\mathbf{a}}$ & 3 \\
\hline $\mathbf{5}^{\mathbf{a}}$ & 2 \\
\hline $\mathbf{6}^{\mathbf{a}}$ & 2 \\
\hline $\mathbf{7}^{\mathbf{a}}$ & 3 \\
\hline $\mathbf{8}^{\mathbf{a}}$ & 3 \\
\hline $\mathbf{1 0}^{\mathbf{a}}$ & 4 \\
\hline $\mathbf{T o t a l}^{\mathbf{a}}$ & 22 \\
\hline
\end{tabular}

Fonte: Elaboração própria (agosto - outubro de 2015).

Tabela 5: Quantitativo de observações e entrevistas realizadas em cada instituição

Equipamento Número de observações e Número de observações Cultural entrevistas feitas pela entrevistas feitas por pesquisadora integrantes do GEPEMCI

\section{CCBB}

2

3

CCPJ

2

2

Centro Municipal de

3

0

Arte Hélio Oiticica

\begin{tabular}{llll}
\hline Espaço & Oi & Futuro & 4
\end{tabular}

(Flamengo)

\begin{tabular}{lcc}
\hline Fundação Eva Klabin & 3 & 1 \\
\hline MAR $^{14}$ & 0 & 0 \\
\hline $\begin{array}{l}\text { Museu Nacional da } \\
\text { UFRJ }\end{array}$ & 3 & 1 \\
\hline Total & & \\
\hline
\end{tabular}

Fonte: Elaboração própria (agosto - outubro de 2015)

\footnotetext{
${ }^{14}$ Muitas tentativas, sem sucesso, foram feitas para observação no Museu de Arte do Rio. No entanto, a instituição exigiu uma autorização especial para acompanhar as mediações. Quando a autorização foi concedida, a partir de um contato na SME, infelizmente, todas as incursões para a realização da observação fracassaram, pois as visitas foram canceladas.
} 
Não é possível deixar de mencionar que alguns percalços aconteceram durante a realização do trabalho de campo. Primeiramente, a disponibilização por parte da SME/RJ do calendário de agendamento de visitas das escolas às instituições só ocorreu duas semanas após o início do Projeto.

Um segundo desafio foi a tentativa de conciliar a rotina de observação, já que a visita das escolas aos museus e centros culturais aconteciam de modo simultâneo. A maneira encontrada para mitigar a situação foi contar com a ajuda espontânea de integrantes do GEPEMCI nos dias e horários conflitantes ${ }^{15}$. Além disso, por diversas vezes as CREs não disponibilizaram o ônibus que conduziria os alunos e docentes às visitas, gerando um transtorno de difícil reparação na agenda inicial apresentada. Deste modo, algumas escolas não conseguiram nem mesmo ir às sete instituições previstas no Projeto Escola e Museu ${ }^{16}$. Também foram vivenciados cancelamentos por questões adversas, tais como: atraso do ônibus, motoristas que conduziram os participantes a instituições erradas e confrontos violentos no entorno das unidades escolares, inviabilizando o deslocamento dos alunos. Ao procurar o setor responsável na SME/RJ sobre a possibilidade de reagendamento, fui informada que o mesmo seria feito, mas, apesar da minha insistência, não disponibilizaram a nova agenda do Projeto, impossibilitando algumas observações.

No entanto, a pesquisa não é mera observação, deve estar presente um caráter reflexivo, já que os sujeitos são subjetivos. Exemplificando, é fundamental especificar em quais espaços se deu a observação (museu, centro cultural etc) porque o ambiente pode refletir no tipo de comportamento do sujeito observado. É importante que o pesquisador vá a campo com o olhar aberto para se surpreender e buscar o sentido e valor das práticas e relações observadas, sem, no entanto, julgá-las. Ou seja, é necessário que o pesquisador reconheça a sua subjetividade para ajudar a dar mais objetividade à pesquisa. Como já explicitado por Da Matta (1978), é também preciso fazer o exercício de estranhar o que é familiar, já que estamos a vida toda dentro da escola e, logo, é um ambiente muito familiar, e o "comum" pode passar porque estamos com o olhar treinado. Assim, o objeto de estudo, a orientação teórico-metodológica, as ações realizadas no campo de

\footnotetext{
${ }^{15}$ Todas as integrantes colaboradoras obtiveram informações sobre a pesquisa e tinham acesso ao mesmo roteiro de observação e entrevista, por mim elaborados.

${ }^{16}$ Tal Projeto será apresentado e detalhado no capítulo 3.
} 
pesquisa, a forma de acesso aos dados, o trabalho de análise realizado e as interpretações são aspectos que irão determinar o resultado final da pesquisa.

Para Geertz (1999), estaremos sempre diante de uma versão dos fatos e essa versão é parcial e provisória, já que os relatos das pesquisas expressam não a realidade observada, mas uma construção a partir dos nossos pressupostos, do nosso olhar na observação e do recorte que fazemos de uma realidade que é tão complexa e multifatorial. Dessa forma, o pesquisador deve registrar, narrar e situar os acontecimentos de modo consciente, ou seja, controlando as variáveis e o impacto de sua presença em campo para minimizar os ruídos na coleta e análise dos dados.

Tura (2003) defende que é preciso explicitar tudo de modo detalhado porque nada fala por si e uma forma de aplicar é através da descrição densa, ou seja,

um esforço de articulação entre os fatos, o envolvimento na lógica de sua organização, o decifrar dos aspectos obscuros, o buscar pistas para desvendar certos mistérios. Tudo isso exige que a atividade fundamental do pesquisador seja a interpretação/reinterpretação dos acontecimentos. Esta é a forma de tornar os símbolos inteligíveis. (p. 190).

De modo complementar, é necessário assinalar como se deu a interpretação dos dados. Para que ocorra um mergulho tanto na observação quanto na interpretação densa (tradução e elaboração pessoal do que foi observado) é preciso um movimento permanente entre aproximação e distanciamento do pesquisador em relação ao seu objeto. Tura (2003) ressalta que, nesse momento, os textos produzidos a partir da observação no campo de investigação vão passando, então, por um processo de refinamento, exigindo que sejam refundidos e reinterpretados até que se produza um documento final.

Esta tese foi organizada da seguinte forma: O capítulo 1 - As dimensões da qualidade educacional - apresenta o embasamento teórico que permitiu a compreensão da perspectiva acadêmica.

O terceiro capítulo desta tese - Cultura, formação cultural e os espaços de educação não formal apresenta a discussão teórica relativa à dimensão cultural e à experiência estética.

O capítulo 3 - O Projeto Escola e Museu - traça a história do projeto, apresenta cada uma das instituições parceiras da SME/RJ, bem como uma análise 
do contexto da prática, abordando as estratégias de seleção dos docentes e alunos participantes e a reinterpretação do projeto por parte dos equipamentos culturais.

O quarto capítulo - A formação cultural de qualidade e as múltiplas experiências - exibe a análise dos dados produzidos a partir das observações, entrevistas e análise documental da proposta.

O capítulo 5 - A avaliação do Projeto Escola e Museu - apresenta a visão dos museus e centros culturais sobre o projeto, bem como as considerações feitas pelos docentes e alunos participantes.

Nas Considerações finais, o percurso percorrido nesta tese é retomado e são tecidas mais algumas reflexões, além de propor possíveis desdobramentos da pesquisa. 


\subsection{As dimensões da qualidade educacional}

Diferentes canais de comunicação, recorrentemente, fornecem informações acerca do cotidiano educacional, colocando o tema em pauta. Porém, muitas vezes, cria-se apenas um ângulo e o apresenta como única possibilidade de apontar e pensar o tema, além de conduzir o que é ou não relevante a ser discutido e percebido na realidade social. Além disso, quanto mais afastado estiver o consumidor dessa realidade, ou seja, quanto menos vivência e experiência no campo educacional, mais a narrativa e o ângulo apresentados pela mídia sensibilizarão e moldarão o olhar de quem consome seus produtos. Silverstone (2002) adverte que as nossas experiências podem propiciar a mudança de olhar sobre o ângulo que a mídia tenta impor.

Sendo assim, nos discursos produzidos sobre a educação brasileira, agindo como veículo de responsabilização branda das escolas e dos docentes, a mídia, de modo geral, possibilita e impulsiona a criação de rankings e estereótipos do que se configura como melhor sistema de ensino, gestão escolar, professor, família e aluno. As comparações e ranqueamentos entre diferentes sistemas de ensino e escolas não se configuram como o principal objetivo dos processos de avaliação, já que as realidades escolares são tão diferentes. As avaliações e seus resultados foram delineados para que as escolas pudessem acompanhar em longo prazo os seus próprios progressos e desenvolvessem estratégias de melhoria do ensino. Quando a mídia publiciza os dados educacionais, pode acirrar a competição entre os diferentes estabelecimentos escolares e, através de seus produtos, criar um imaginário de que a explicação das performances apresentadas nos processos avaliativos está em nível individual e que não passa pela esfera governamental, provocando a responsabilização dos gestores e docentes e, muitas vezes, a desresponsabilização do Estado avaliador.

Essa situação é especialmente delicada porque há outras fontes de informação sobre a realidade educacional brasileira, mas que são de difícil acesso à população, como, por exemplo, os relatórios de avaliação da Prova Brasil. Tais documentos apresentam a definição de avaliação, os objetivos, a metodologia, o tratamento dos dados e os resultados encontrados, bem como considerações sobre esses resultados. No entanto, tais relatórios apresentam informações de complexa compreensão para aqueles que não são do meio acadêmico, além de não serem 
amplamente divulgados. Deste modo, a mídia encontra espaço para fazer essa mediação com a grande massa e assume o papel de divulgadora dos dados, porém, ressignifica e didatiza as informações através, por exemplo, de imagens, gráficos e tabelas que passam a nortear as ideias que serão construídas a respeito do cenário da educação nacional. E, de modo geral, realiza essa divulgação de forma convincente, estabelecendo uma relação de confiança com os seus consumidores que, por meio de suas matérias, acreditam que entenderam as avaliações em larga escala, aprenderam caminhos para o sucesso de seus filhos e encontraram possíveis culpados para o fracasso escolar.

Os estudos realizados por Esquinsani \& Esquinsani (2012) demostram que as avaliações em larga escala têm merecido constante atenção dos canais midiáticos, expressa em notícias e reportagens que apresentam informações e manifestam opiniões sobre o assunto. Os autores investigaram oitenta e sete produtos midiáticos veiculados em três semanários (Revistas Veja, Isto É e Época). Com o objetivo de mapear a repercussão da Língua Portuguesa como objeto de avaliações em larga escala, concluíram que a maioria das discussões valoriza a avaliação em Língua Portuguesa, em detrimento da disciplina Matemática, e que tais discussões recaem em questões periféricas, ou seja, não abordavam a centralidade do componente curricular como objeto dos processos de ensino e aprendizagem.

Os produtos midiáticos pouco abordaram o que, para os autores, seria essencial na discussão: o que está sendo avaliado em Língua Portuguesa nas avaliações em larga escala. Além disso, os autores ressaltaram uma preocupação com os docentes de Língua Portuguesa, pois, como a mídia valoriza muito os resultados nessa disciplina, será que os docentes dessa área serão mais cobrados nas situações de fracasso escolar e baixo desempenho dos alunos nas avaliações de larga escala?

Também investigando o papel da mídia na perspectiva aqui apontada, Gasparin e Soligo (2011) analisaram jornais do estado de Santa Catarina publicados em mídia eletrônica e ou impressa (janeiro a maio de 2009), somando vinte e três reportagens sobre avaliações de larga escala, e mais de $80 \%$ versavam sobre os resultados do ENEM. Com o objetivo de identificar os impactos gerados pela exposição dos resultados à população, os autores concluíram que a mídia divulga índices, rankings e os problemas que a educação atravessa na atualidade, 
porém, faltam esclarecimentos sobre os mecanismos de construção e aplicação da avaliação e os objetivos das provas padronizadas em larga escala configuram-se como aspecto pouco abordado. Constataram que apenas duas reportagens mencionaram as diferenças entre as realidades de cada escola, contextualizando a discussão sobre as condições sociais e econômicas.

Em outra pesquisa, Esquinsani (2010) averiguou que a mídia assume, com destaque, o papel de divulgar a aplicação e os resultados das avaliações em larga escala, publicizar os indicadores produzidos por tais avaliações ou comentar resultados e, dessa forma, coloca o tema em pauta nos debates nacionais. $\mathrm{Na}$ investigação realizada, analisou 1.924 produtos midiáticos recolhidos a partir dos elementos disponíveis online nos sites de três revistas semanais mencionadas anteriormente (Veja, Isto É e Época), entre e 1996 e 2007, dividindo-os em três categorias: i) produtos midiáticos que colocam o professor como responsável pelos resultados das avaliações de larga escala, seja como o grande responsável pela melhoria da educação, ou como o "vilão"; ii) a valorização exacerbada que a mídia transfere aos índices, à performance, valorizando os primeiros lugares dos rankings; iii) produtos midiáticos que se empenham em passar fórmulas e sugestões para o sucesso individual nas avaliações em larga escala. Concluiu então que a mídia focaliza a competição e o desempenho como parâmetros de qualidade, fugindo do escopo central dos processos de avaliação propostos pelo governo.

Portanto, muito do que se discute com a sociedade sobre a qualidade educacional gira em torno do desempenho dos estudantes nas avaliações em larga escala, de modo simplificado, abordando de modo periférico as questões de contexto.

Pensando na educação como um processo que gera experiências mais amplas e que não são capturadas apenas por meio das avaliações em larga escala, de que modo é possível entender a formação cultural dos alunos? Tal quesito não é avaliado por nenhum instrumento nacional e, desse modo, as diferentes dimensões da qualidade educacional ficam em desequilíbrio na pauta de discussão. O que sabemos sobre a apreciação, contextualização e produção cultural de nossos alunos?

A seguir, são aprofundadas as duas dimensões da qualidade educacional aqui mencionadas: a acadêmica e a cultural. 


\subsection{Avaliação e responsabilização docente}

O tema 'avaliação' tem sido amplamente discutido na esfera política, nos espaços de pesquisa educacionais e no seio das escolas. Na coleção 'Indagações sobre o Currículo - Currículo e Avaliação' (MEC, 2007) são explicitados os três níveis de avaliação: i) a avaliação da aprendizagem dos estudantes (avaliação cotidiana elaborada pelo docente); ii) a avaliação da instituição (desenvolvida pelo coletivo da escola, buscando avaliar os avanços e defasagens de uma dada organização escolar) e iii) a avaliação do sistema escolar ou do conjunto de escolas em âmbito nacional (cuja responsabilidade é do poder público em avaliar o conjunto de escolas de uma dada rede ou de redes nacionais).

Assim, a avaliação do sistema nacional de educação assume o papel de gerar um panorama do ensino ofertado nas diferentes redes e nacionalmente, tendo o potencial de, a partir dos resultados, fornecer elementos para adequar as políticas públicas educacionais e criar condições de democratização do ensino, bem como gerar uma discussão nas escolas para que as mesmas possam se apropriar dos resultados e traçar estratégias de melhoria da qualidade da educação.

É inerente ao processo avaliativo o potencial de fornecer conhecimento básico para suporte estratégico e tomada de decisões políticas educacionais, ou seja, apresentando a possibilidade de desenvolver melhorias através do sistema de accountability. Vianna (1997), tentando traduzir de modo preciso o termo afirmou que

aos poucos começou a impor-se o conceito de accountability, palavra difícil de traduzir com exatidão; contudo, percebe-se que está relacionada à expressão to be accountable for - ser responsável por - daí a tradução que usualmente empregamos - responsabilidade educacional. Por outro lado, é preciso lembrar, também, que account tem um sentido contábil, financeiro. Haveria, assim, uma preocupação maior com as grandes despesas governamentais para a obtenção de resultados muitas vezes decepcionantes, em decorrência, inclusive, da irrelevância metodológica da maioria dos projetos. (p. 178-179).

Soares (2007) explicita o caráter mais voltado para o gerenciamento que o termo assumiu na gestão pública educacional:

uma forma de relação entre a escola e o sistema cada vez mais considerada é a chamada responsabilização social, tradução do termo da língua inglesa accountability. São vários os formatos possíveis, mas em todos eles está implícita a ideia de alocação seletiva de mais recursos tendo como contrapartida os resultados obtidos (p. 148). 
Um exemplo elucidativo é a divulgação pública do Ideb por escola, o que permite à sociedade cobrar uma maior eficácia do sistema educacional público, exigindo melhorias na qualidade do ensino ofertado, além de possibilitar que famílias escolham as escolas em que vão colocar seus filhos com base nos resultados dessas avaliações externas. Para Almeida e Silva (2008),

a ênfase em procedimentos de avaliação e prestação de contas faz parte do corolário de medidas políticas e legislativas que afetaram a administração pública em geral, e em específico a educação, no bojo das reformas e re-estruturação do Estado desde a década de 1980, alcançando o seu auge na década de 1990 (p. 15).

Esse conjunto de ações fazia e ainda faz parte de um intenso processo de redefinição do papel e da ação do Estado e dos diferentes agentes sociais. Especialmente as práticas avaliativas desenvolvidas em âmbito federal, bem como a matriz de referência do Saeb e da Prova Brasil, inspiraram estados e municípios a desenvolverem seus próprios instrumentos de avaliação que são, muitas vezes, censitários em relação às suas escolas. Esse tipo de regulação exercida complementa as informações disponibilizadas pelo Governo Federal, já que, em alguns casos, tais sistemas avaliam outras séries ou, até mesmo, o $5^{\circ}$ e o $9^{\circ}$ anos do ensino fundamental nos anos pares, ou seja, intercalados às avaliações realizadas pelo Inep, já que as mesmas são bianuais. Além disso, alguns governos se utilizam dos resultados do Ideb e de seus próprios índices em políticas de responsabilização.

\subsubsection{A avaliação externa em larga escala no Brasil: uma história em construção}

A primeira avaliação externa em larga escala do Sistema de Avaliação da Educação Básica (Saeb) foi aplicada em 1990, contemplando uma amostra de estudantes de algumas escolas da rede pública urbana matriculados nas $1^{\mathrm{a}}, 3^{\mathrm{a}}, 5^{\mathrm{a}} \mathrm{e}$ $7^{\text {a }}$ séries do ensino fundamental, que tiveram os seus conhecimentos de língua portuguesa, matemática e ciências testados. O objetivo era construir um diagnóstico da qualidade educacional, com a finalidade de subsidiar as políticas públicas, buscando a melhoria do ensino.

Em 1995, o Saeb passou por um processo de reformulação metodológica, adotando-se a Teoria de Resposta ao Item (TRI), gerando a possibilidade de comparação entre os resultados ao longo dos ciclos de avaliação. Além disso, 
outras medidas foram igualmente fundamentais, como a decisão de que os alunos avaliados seriam aqueles matriculados nas séries finais de cada segmento $\left(4^{\mathrm{a}}\right.$ e $8^{\mathrm{a}}$ séries do ensino fundamental/ $5^{\circ}$ e $9^{\circ}$ anos do ensino fundamental) e $3^{\circ}$ ano do ensino médio e a inclusão de uma amostra de escolas representativas da rede privada.

Entretanto, em 2005, o Saeb foi remodelado e, até os dias atuais, a Educação Básica brasileira é avaliada por dois mecanismos complementares. O primeiro é a Avaliação Nacional da Educação Básica (Aneb), que manteve a aplicação de modo amostral a estudantes das redes públicas e privadas de escolas situadas em áreas urbanas e rurais, inscritos nos $5^{\circ}$ e $9^{\circ}$ anos do ensino fundamental e no $3^{\circ}$ ano do ensino médio. O segundo mecanismo é a Avaliação Nacional do Rendimento Escolar (Anresc), cuja aplicação é censitária, ou seja, abrange todos os alunos matriculados nos $5^{\circ}$ e $9^{\circ}$ anos do ensino fundamental público, em escolas que tenham o quantitativo mínimo de 20 alunos na série avaliada, tanto nas redes municipais, estaduais e federais, incluindo as áreas rurais e urbanas. Nesse caso, o teste padronizado chama-se "Prova Brasil", oferecendo a possibilidade de devolver os resultados por escola, município, unidade federativa e país. Em ambos os casos, os alunos são avaliados apenas nas disciplinas de Língua Portuguesa (leitura) e Matemática (resolução de problemas).

De acordo com o Instituto Nacional de Estudos e Pesquisas Educacionais Anísio Teixeira,

a Prova Brasil foi idealizada para atender a demanda dos gestores públicos, educadores, pesquisadores e da sociedade em geral por informações sobre o ensino oferecido em cada município e escola. O objetivo da avaliação é auxiliar os governantes nas decisões e no direcionamento de recursos técnicos e financeiros, assim como a comunidade escolar, no estabelecimento de metas e na implantação de ações pedagógicas e administrativas, visando à melhoria da qualidade do ensino. ${ }^{17}$

Além das avaliações, os alunos preenchem um questionário socioeconômico, com informações sobre fatores de contexto que podem auxiliar na interpretação do desempenho dos mesmos. Complementarmente, professores e diretores das turmas e escolas avaliadas também respondem a questionários que coletam informações demográficas, dados sobre o perfil profissional e sobre as

\footnotetext{
${ }^{17}$ Disponível em: http://paraiba.pb.gov.br/governo-do-estado-realiza-treinamento-para-430aplicadores-da-prova-brasil/. Acesso em: 7 fev. 2016.
} 
condições de trabalho.

A média calculada a partir do desempenho dos alunos de cada escola, tanto em língua portuguesa quanto em matemática, apresenta-se como subsídio, juntamente com os dados de fluxo escolar (taxa de aprovação dos alunos), para o cálculo do Índice de Desenvolvimento da Educação Básica (Ideb). Tal índice é aferido a cada dois anos, com o objetivo de que cada escola atinja, no mínimo, a nota 6,0 até 2021, que corresponde ao valor atual das escolas de qualidade dos países desenvolvidos membros da Organização para a Cooperação e o Desenvolvimento Econômico (OCDE).

No primeiro ano de avaliação do Ideb (2005), a média foi 3,8 nos primeiros anos do ensino fundamental. Dessa forma, os sistemas educacionais municipais, estaduais e federais possuem metas de qualidade a serem alcançadas. $\mathrm{O}$ MEC tem contribuído oferecendo suporte técnico e/ou financeiro às redes municipais que apresentavam índices de qualidade abaixo do esperado, a partir da adesão ao Compromisso Todos pela Educação e da elaboração do Plano de Ações Articuladas (PAR). Atualmente, todos os municípios brasileiros estão comprometidos em atingir as metas propostas pelo MEC. Além disso, alguns governos estaduais e municipais tomaram a iniciativa de desenvolver seus próprios índices e processos de avaliação em larga escala, buscando acompanhar mais de perto os seus sistemas de ensino, inclusive nos anos em que não são avaliados pela Prova Brasil, já que a mesma acontece apenas em ciclos de dois em dois anos.

A seguir, apresento alguns resultados de pesquisa que versam sobre esse tipo de avaliação e responsabilização docente.

\subsubsection{As temáticas avaliação e responsabilização docente nas pesquisas nacionais}

Bonamino e Souza (2012) investigaram as iniciativas de avaliação dos sistemas nacionais de ensino visando à promoção e o acompanhamento da qualidade educacional. As autoras fazem uma análise de três grandes gerações de avaliação, apresentadas a seguir, relatando que essa tendência é fortemente influenciada por iniciativas internacionais, como, por exemplo, o Programme for International Student Assessment (Pisa) - Projeto Internacional de Avaliação de 
Estudantes $^{18}$, aplicado desde 2000, e que essas ações trazem impactos no currículo escolar. Cabe destacar que a divisão em três gerações é um recurso analítico utilizado pelas autoras e que as avaliações abaixo citadas convivem e, não necessariamente, se superam.

A $1^{\text {a }}$ geração é feita com caráter diagnóstico da qualidade da educação ofertada nacionalmente, sem atribuição de consequências diretas para as escolas e para o currículo. O exemplo citado pelas autoras é o Saeb, criado em 1991 e, anterior ao PISA, com caráter amostral. Tal sistema gera as primeiras informações acerca do desempenho dos estudantes das $4^{\mathrm{a}}$ e $8^{\mathrm{a}}$ séries do ensino fundamental e $3^{\circ}$ ano do ensino médio, bem como informações sobre fatores associados a esses resultados. Além disso, como esses resultados não trazem consequências para o interior das escolas, os profissionais não se sentem obrigados a prestar conta do desempenho de seus alunos nas avaliações e nem a usá-lo para gerar mudanças no planejamento e na prática pedagógica.

A $2^{a}$ geração citada no artigo é caracterizada pela divulgação pública dos resultados e devolução dos dados para as escolas; no entanto, esse resultado não gera consequências materiais, mas sim simbólicas. Essa seria uma política de responsabilização do tipo branda. Dessa forma, a sociedade pode usar os índices para exigir melhorias na qualidade do ensino ofertado, além de permitir que famílias escolham as escolas em que vão colocar seus filhos com base nos resultados dessas avaliações externas. O exemplo citado é a Prova Brasil, implementada em 2005 apenas para o ensino fundamental. A grande vantagem dessa avaliação é que a mesma é censitária, permitindo que o resultado alcançado pelas escolas seja comparado a cada novo ciclo de avaliação, permitindo também o direcionamento de recursos técnicos e financeiros e a inserção de uma preocupação pedagógica que visa melhorar a qualidade do ensino. A partir de 2007, com os dados de desempenho da Prova Brasil e de fluxo do Censo Escolar foi construído o Ideb. Adicionalmente, foram divulgadas as matrizes de referência

\footnotetext{
${ }^{18}$ O PISA é uma iniciativa de avaliação comparada, aplicada a estudantes na faixa dos 15 anos, idade em que se pressupõe o término da escolaridade básica obrigatória na maioria dos países. O Projeto é desenvolvido e coordenado pela Organização para Cooperação e Desenvolvimento Econômico (OCDE). Em cada país participante há uma coordenação nacional. No Brasil, o Pisa é coordenado pelo Instituto Nacional de Estudos e Pesquisas Educacionais Anísio Teixeira (Inep). Disponível em: http://portal.inep.gov.br/pisa-Projeto-internacional-de-avaliacao-de-alunos. Acesso em: 29 dez. 2015.
} 
das provas de leitura e matemática, acarretando uma interferência nos currículos e ações escolares.

A $3^{\text {a }}$ geração é marcada, segundo Bonamino e Souza (2012), pelas ações governamentais que passam a apropriar-se dos resultados das avaliações para responsabilizar as equipes pedagógicas, estipulando metas que, se alcançadas, trazem bonificações salariais. Essa seria uma política de responsabilização do tipo forte. Logo, as avaliações, que tinham como proposta fornecer dados para nortear as políticas educacionais e o planejamento escolar, alcançam seus objetivos, mas trazem novos desafios. As pesquisas nesse campo registram estratégias de treino para as provas como, por exemplo, a disponibilização de materiais estruturados para alunos e professores que estão alinhados às matrizes das avaliações. Desse modo, o currículo ensinado fica muito mais voltado para os conteúdos que estarão presentes nas avaliações.

A pesquisa de Alves \& Soares (2013) colocou em foco a discussão sobre a introdução do Ideb pelo governo federal, parâmetro que gerou mudanças no modo como a educação é acompanhada pelos brasileiros com a adoção de metas preestabelecidas. Os autores afirmaram que o seu uso tem suscitado debates sobre o tipo de política de responsabilização que o indicador produz, já que são gerados resultados que não consideram o contexto escolar, ou seja, não são incluídos fatores como o perfil dos alunos e as características intraescolares.

Os autores levaram em consideração tais elementos, por meio de uma regressão linear múltipla, e constataram que as escolas que atendem a alunos de menor nível socioeconômico têm piores resultados, o que dificulta a elevação do Ideb, sendo, necessário, portanto, o desenvolvimento de políticas públicas educacionais que superem tal desafio.

O trabalho de Mesquita (2012) buscou evidenciar os impactos da divulgação dos resultados do Ideb sobre o cotidiano de uma escola pública do Rio de Janeiro. A escola Darwin (nome fictício) foi selecionada para ser investigada devido aos resultados positivos no Ideb, de 2005 até 2011, principalmente no segundo segmento do ensino fundamental. A autora ressaltou que um dos problemas da divulgação desses resultados pela mídia está no uso indevido que alguns governos fazem destes indicadores, às vezes de forma precipitada, com a necessidade de buscar responsáveis pelo insucesso da escola e, assim, desresponsabilizando os próprios governos. Contudo, Mesquita (2015) constatou 
que a divulgação dos resultados de 2005 , cujo desempenho foi muito baixo, e a visita da equipe de um jornal televisivo que é veiculado para o Estado do Rio de Janeiro geraram um forte impacto positivo no cotidiano dessa escola, já que tal situação levou a instituição a buscar estratégias para superar os indicadores apresentados, principalmente porque a escola já tinha uma história de sucesso na comunidade, ou seja, houve uma mobilização da equipe para melhorar o desempenho nas avaliações seguintes.

É preciso questionar esse efeito considerado positivo pela autora porque, no depoimento da coordenadora pedagógica, a justificativa apresentada para o baixo Ideb em 2005 era que os professores não estavam preparados e não separavam os alunos que iam fazer a prova do restante. Essa estratégia de classificação dos alunos dentro do espaço escolar é um dos efeitos colaterais das políticas de responsabilização porque oferece pistas de que a escola não está se preocupando em tentar melhorar o desempenho dos alunos com problemas na aprendizagem, mas sim excluindo os mesmos no dia das avaliações em larga escala, expondo um papel pouco equitativo da qualidade de ensino.

Pereira e Seixas (2012) abordaram o crescimento da insegurança e da instabilidade no interior das escolas como consequência das ações de intervenção pedagógica e administrativa propostas pela Secretaria Municipal de Educação do Rio de Janeiro (SME/RJ). Partiram da análise de materiais de jornais e conteúdo presente no site da SME/RJ, já que este é um forte canal de comunicação com as escolas e seus profissionais, e, de modo complementar, também observaram uma escola da rede. De acordo com as pesquisadoras, foi possível identificar, no discurso do prefeito em exercício e da administração educacional municipal, uma tentativa de aproximar o modelo de gestão pública do modelo empresarial privado como, por exemplo, a adoção de critérios de performatividade e de premiação dos melhores desempenhos (responsabilização).

Além disso, durante a fase de observação da Escola Amanhã (nome fictício), as autoras constataram que as novas exigências podem sobrecarregar e reorientar o papel da direção na escola, mas também podem criar condições para uma gestão partilhada e democrática, como por exemplo, o professor de educação física colaborava com as questões financeiras.

Pereira e Seixas (2012) finalizaram a discussão questionando a eficácia de políticas que, com a premiação, contribuem para o estabelecimento de uma 
competitividade que pode trazer ainda mais dificuldade àquelas instituições que precisam de investimentos financeiros, políticos e pedagógicos para superar os seus problemas.

Augusto (2012) apresentou e analisou as políticas públicas educacionais desenvolvidas pelo sistema estadual de ensino em Minas Gerais, caracterizadas pela obrigação do cumprimento de metas, visando identificar seus efeitos sobre as relações de trabalho docente por meio de levantamento documental. A autora verificou que as medidas de responsabilização pelo êxito ou pelo fracasso dos alunos nos sistemas de avaliação em larga escala recaem sobre os professores, no entanto, as metas são elaboradas sem a participação dos docentes. Assim como no trabalho de Alves e Soares (2013), não foram levados em consideração itens fundamentais como as condições de trabalho docente na rede estadual de ensino em Minas Gerais.

O estudo desenvolvido por Ximenes (2012) analisou a relação entre a responsabilização e a qualidade do ensino, retomando as resoluções da Conferência Nacional de Educação ${ }^{19}$. A autora discutiu a transformação do Ideb de política de governo em política de Estado, abrindo-se a possibilidade de atrelar o comportamento dos gestores às metas de desempenho, responsabilizando-os. Destacou, então, que essa responsabilidade tenderá a recair sobre os gestores e sobre os demais trabalhadores da educação e, assim, a responsabilização pelo fracasso dos alunos nos testes, em última instância, recairá sobre os trabalhadores da educação.

Discutindo a relevância de formas alternativas de regulação da qualidade educacional em relação às avaliações que focalizam os resultados dos alunos, Sordi (2012) investigou a experiência de uma rede municipal de ensino que tem como foco as reuniões de negociação entre os gestores do nível central e os atores das escolas e conseguiu observar que estes últimos tendem a aprimorar o entendimento de seu papel na negociação e há indícios de ampliação do protagonismo e da implicação dos atores das escolas. Para a autora, motivadores externos como, por exemplo, a bonificação por meritocracia, tendem a enviesar as razões pelas quais se luta por uma escola pública de qualidade.

Alertando para os riscos das políticas de responsabilização, através do

\footnotetext{
${ }^{19}$ Para mais informações, acessar: http://conae.mec.gov.br/. Acesso em: 20 jul. 2017.
} 
estudo da produção americana, já que essa temática foi largamente medida nesse país, Freitas (2012) apontou em sua pesquisa os principais impactos: estreitamento curricular, competição entre profissionais e escolas, pressão sobre o desempenho dos alunos e preparação para os testes, fraudes, aumento da segregação socioeconômica no território, aumento da segregação socioeconômica dentro da escola, precarização da formação do professor, destruição moral do professor, destruição do sistema público de ensino, ameaça à própria noção liberal de democracia.

Por fim, defendeu que ainda há tempo para o Brasil não implementar tais políticas e evitar mais uma década perdida para a educação brasileira. Em sua pesquisa de 2007, o autor criticou as formas de introdução de políticas de avaliação baseadas em responsabilização em curso no MEC-INEP, alertando para o fato de que as políticas de responsabilização unilaterais podem acarretar a segregação em escolas para pobres e escolas para ricos, além de camuflar as dificuldades que as classes populares estão tendo para aprender no interior da escola, corroborando estratégias que marcam ações de exclusão, ou seja, um sistema que não distribui de forma homogênea uma educação de qualidade.

Andrews \& Vries (2012) apresentaram os resultados do impacto da pobreza sobre o Ideb em um universo de 5.500 municípios, fazendo comparações, entre as esferas municipal e estadual, dos resultados de 2005, 2007 e 2009, e concluíram que a pobreza provoca um forte impacto no desempenho escolar. Os autores revelaram que alguns Projetos oriundos das políticas de responsabilização, como, por exemplo, a bonificação realizada em São Paulo, desconsideram o impacto da pobreza nos resultados escolares, o que pode provocar uma responsabilização dos gestores e docentes menos fiel à realidade, promovendo ainda mais a desigualdade na alocação dos recursos. Deste modo, defenderam que Projetos de desenvolvimento econômico local possivelmente teriam um impacto maior no desempenho escolar.

Já Adrião \& Garcia (2008) dedicaram-se à análise das perspectivas de responsabilização presentes no Plano de Desenvolvimento da Educação apresentado à sociedade brasileira em 2007 pelo então Ministério da Educação, que tinha como alvo a promoção da qualidade da educação básica. Através dessa ferramenta, os gestores comprometiam-se com o alcance de metas e, em contrapartida, podiam contar com transferências voluntárias e assessoria técnica 
da União, caracterizando um processo de responsabilização.

Inicialmente, tal aspecto é regularizado pelo decreto presidencial 6.094/07, que institui o Plano de Metas Compromisso Todos pela Educação, e regulamentado por um conjunto de resoluções expedidas pelo Fundo Nacional de Desenvolvimento da Educação (FNDE). Os autores destacaram que tal política gera pressões no interior da escola para que se cumpram as metas e as consequências desse processo devem ser acompanhadas, pois existe a possibilidade de provocar o aumento da desmotivação e desestímulo dos educadores caso as metas não sejam cumpridas, apesar de sua concentração de esforços. Além disso, os recursos repassados às escolas podem ser reduzidos, ocasionando o aumento das desigualdades já existentes no sistema.

O estudo desenvolvido por Alves (2008) analisou a associação de políticas públicas brasileiras sobre o desempenho das redes de ensino das capitais brasileira a partir dos rendimentos dos alunos da $4^{\mathrm{a}}$ série do ensino fundamental no Saeb. E no que concerne à presente discussão, os resultados encontrados apontaram que as políticas relacionadas à transparência e responsabilização apresentaram um impacto positivo, ainda que não significativo, no rendimento discente. A autora avultou que embora sejam esparsos e não consensuais os achados sobre a contribuição desse tipo de política para o aumento do desempenho dos alunos, tal temática deve permear o debate educacional no Brasil, na tentativa de renovar e diversificar a agenda política brasileira, buscando-se estratégias e políticas mais efetivas em relação à melhoria da qualidade da educação ofertada.

Abordando o surgimento das políticas de responsabilização no cenário internacional, especificamente na Inglaterra e nos Estados Unidos, Brooke (2006) avaliou as primeiras experiências de implementação dessa política no contexto brasileiro buscando identificar se havia a possibilidade dessa estratégia se tornar elemento central dos sistemas educacionais nacionais. As três experiências examinadas foram: o Prêmio Educacional Escola do Novo Milênio - Educação Básica de Qualidade no Ceará, o Projeto Nova Escola da Secretaria de Educação do Estado do Rio de Janeiro e o Boletim da Escola da Secretaria de Educação do Estado de Paraná.

O autor concluiu que a crescente preocupação com os dados fornecidos pelas avaliações em larga escala e com os efeitos da baixa qualidade da escola no futuro do país tem favorecido, ainda que em pequena escala, a disseminação das 
políticas de responsabilização no Brasil. Brooke (2006) também sinalizou alguns fatores que têm representado um desafio nesse processo: questões operacionais dos Projetos, a resistência do magistério a esse tipo de política e a pouca utilização dos resultados da aprendizagem cognitiva dos alunos como peça-chave da política educacional. Neste sentido, o autor registra que falta uma cultura de avaliação que permita utilizar o desempenho dos alunos como indicador da qualidade do ensino ofertado.

A partir da análise das ações do governo federal durante a gestão do presidente que esteve em exercício no período de 1995 a 2002, no que se refere a avanços e sistematizações dos modelos de avaliações da educação nas diferentes amplitudes, seja enquanto desempenho cognitivo dos alunos (Saeb e Enem, por exemplo) ou Projetos (Projeto Nacional do Livro Didático - PNLD), e o quanto esse tipo de iniciativa possibilitou o monitoramento e a formulação de políticas públicas baseadas em evidências, De Freitas (2004) apresentou o cenário internacional e relatou o tardio processo brasileiro em se pensar e colocar em prática ações avaliativas que fossem além do desempenho. Ultrapassando essa questão, em um caráter normativo, percebe-se também uma ausência de maior esclarecimento do que seria uma medição da qualidade da educação. A avaliação teria, portanto, um papel importante a desempenhar no cenário educacional brasileiro, estando presente em diferentes âmbitos: gestão escolar, currículo e desempenho discente, tomando-se esses componentes não apenas como categorias isoladas, mas entendendo-os em sua interconexão.

Uma importante contribuição apontada pela autora também se refere a iniciativas, regulamentadas por lei, que possibilitaram um maior monitoramento e acompanhamento da situação educacional brasileira a partir de dados estatísticos sistematizados. Neste sentido, a consolidação do censo escolar, através da Lei 9294/96, é considerada um grande avanço, pois, dentre outros fatores, possibilita um direcionamento de verbas.

A partir da revisão de literatura aqui apresentada, foi possível constatar que, embora na última década tenha havido um avanço no que se refere à ampliação e interesse sobre o tema avaliação em virtude dos rumos das políticas públicas educacionais recentes, ainda são escassos os estudos sobre essa temática no campo educacional e seus impactos. A maior parte dos estudos data de 2012, indicando que a discussão sobre as políticas de responsabilização e seus efeitos no 
contexto brasileiro ainda é incipiente, ampliada nos últimos anos.

Brooke (2006) justificava que essa incipiência se devia à falta de um número maior de experiências desse tipo de política no país e pela própria ausência do uso da avaliação como indicador dos produtos da escola. Ainda verificava-se uma animosidade entre os professores e acadêmicos em relação à avaliação em larga escala, e que, como consequência, se estende às políticas de responsabilização.

Além disso, as pesquisas evidenciam uma forte preocupação com os aspectos negativos do accountability educacional, fato destacado pela maior parte dos autores aqui estudados. Nota-se, como bem ressaltado por Alves (2008), que muitos temas relacionados às políticas de accountability são "desconsiderados $a$ priori e interditados por estarem alinhados a concepções políticas consideradas de cunho neoliberal" (p. 434). Em decorrência desse panorama, quando tais temas são trazidos à tona, enfatiza-se, de modo geral, os aspectos negativos da política em detrimento dos positivos.

Neste embate, considero importante ter presente a ressalva feita por Alves (2008). A autora sinalizou que os temas educacionais, quaisquer que sejam, precisam ser discutidos à luz dos resultados de experiências nacionais e internacionais, independente da filiação filosófica e partidária, e, que, dada a diversidade e complexidade da realidade brasileira, é preciso uma postura de abertura à renovação da agenda política. Nesse sentido, Alves (2008) enfatizou que é necessário que acadêmicos, gestores e políticos discutam, sem preconceitos e barreiras, temas usualmente considerados difíceis, como os da avaliação e responsabilização.

Não deixando de lado as críticas a esse modelo de avaliação adotado pelo Governo Federal, Fernandes e Gremaud (2009) apontam que as escolas possuem múltiplos objetivos, enquanto as medidas de resultados utilizadas se detêm em apenas alguns deles, permitindo escapar aspectos fundamentais como, por exemplo, ética, responsabilidade social, preservação ambiental e diversas habilidades não cognitivas que seriam importantes para a formação dos estudantes. Cazelli (2010) relata que o capital social baseado na escola contribui para o alargamento da experiência cultural dos jovens em geral e dos jovens pertencentes às escolas públicas em particular; ou seja, as escolas municipais possuem um papel ativo e equalizador, particularmente relevante para os jovens 
cujas famílias têm menor volume de capital cultural. Esse tipo de contribuição dada pela pesquisa da autora, desenvolvida na cidade do Rio de Janeiro, é outro exemplo de aspecto relevante para a formação do aluno que não é capturado pelas avaliações em larga escala adotadas, ainda que se saiba que o acesso aos bens culturais não é equânime.

O Art. $32^{\circ}$ da LDB 9394/96 estabelece que o ensino fundamental tenha por objetivo a formação básica do cidadão, mediante: I - o desenvolvimento da capacidade de aprender, tendo como meios básicos o pleno domínio da leitura, da escrita e do cálculo; II - a compreensão do ambiente natural e social, do sistema político, da tecnologia, das artes e dos valores em que se fundamenta a sociedade; III - o desenvolvimento da capacidade de aprendizagem, tendo em vista a aquisição de conhecimentos e habilidades e a formação de atitudes e valores; IV o fortalecimento dos vínculos de família, dos laços de solidariedade humana e de tolerância recíproca em que se assenta a vida social.

No contexto aqui apresentado, passo agora a aprofundar tal discussão especificamente a partir do caso da cidade do Rio de Janeiro, objetivando exemplificar algumas iniciativas de avaliação e responsabilização na esfera municipal.

\subsubsection{Os instrumentos de regulação da Secretaria Municipal de Educação do Rio de Janeiro}

No dia $1^{\circ}$ de janeiro de 2009, ao assumir a administração municipal da cidade do Rio de Janeiro, o prefeito revogou o decreto 28.878, que instituía o sistema de progressão contínua. E a então nomeada Secretária de Educação do município declarou que a proposta educacional da rede seria a de gerar um salto na qualidade do ensino (Projeto "Salto de Qualidade na Educação Carioca"), para que cada aluno aprendesse cada vez mais na idade e séries adequadas, política que vem se mantendo desde então.

A noção de qualidade da educação no Brasil foi se modificando ao longo do tempo e é uma expressão polissêmica. Como ressaltado por Sales e Passos (2008), qualidade - do ensino, da escola, da educação - (...) é algo que ninguém pergunta o que é; sabe-se do que se trata, mas que não se sabe explicar. Diante de um questionamento sobre o que é qualidade, não se sabe o que dizer. (p. 293). 


\section{Para Dourado e Oliveira (2009)}

(...) qualidade da educação é um fenômeno complexo, abrangente, que envolve múltiplas dimensões, não podendo ser apreendido apenas por um reconhecimento da variedade e das quantidades mínimas de insumos indispensáveis ao desenvolvimento do processo de ensino-aprendizagem; nem, muito menos, pode ser apreendido sem tais insumos. (p. 205).

Oliveira e Araújo (2005) afirmam que, mesmo entre acadêmicos, é difícil chegar a uma noção única do que seja qualidade da educação. No entanto, os autores destacam que no caso brasileiro é possível perceber essa qualidade da educação de três modos: qualidade determinada pela oferta de ensino, qualidade percebida pelo fluxo e qualidade por meio dos resultados nos sistemas de avaliação.

Atribuo importância significativa à universalização do acesso ao ensino fundamental, posto que esta faz com que "as contradições mudem de lugar", passando a concentrar-se na expansão das etapas posteriores a este e na qualidade da educação básica, notadamente do ensino fundamental. (OLIVEIRA, 2007, p. 666).

No período entre 2009 e 2016 havia uma forte preocupação por parte da gestão da SME/RJ do Rio de Janeiro com o aumento do desempenho nas avaliações externas, a ampliação de vagas para a Educação Infantil, com a responsabilidade sobre a alfabetização dos alunos e com a correção do fluxo. Essas tendências são bem atuais no sentido de que inúmeras pesquisas na área de educação têm abordado esses temas.

Desde 2009 foi implantado um modelo de gestão municipal com base no planejamento e na meritocracia como pilares para a melhoria dos serviços prestados à população, através do Plano Estratégico da Prefeitura do Rio - 20092012. A partir de então, foram introduzidos os "Acordos de Resultados" anuais com o intuito de institucionalizar a cultura de planejamento com metas claras e a participação dos servidores em um modelo de administração meritocrática.

O ano de 2009 foi marcado pelo lançamento do Plano Estratégico 2009-2012 da Prefeitura do Rio de Janeiro. O plano é o principal instrumento do governo para garantir mais foco e transparência à administração da cidade, com o objetivo de traduzir suas aspirações para o futuro, através de iniciativas concretas desta administração.(...)

Para o melhor acompanhamento deste plano foram pactuados Acordos de Resultados, que representam uma ferramenta de gestão usada na administração pública para: (i) garantir um maior comprometimento de toda a máquina pública municipal com os resultados da Prefeitura; (ii) institucionalizar uma nova cultura que privilegie o planejamento com metas claras; (iii) motivar a participação dos 
servidores com um modelo de meritocracia que avalie e premie aqueles que atingirem bons resultados e; (iv) antecipar problemas e apontar soluções através do acompanhamento formal dos resultados obtidos. O que está se propondo é a implementação de um modelo de gestão de desempenho que privilegie o planejamento (metas claras) e a meritocracia como elementos centrais para a melhoria dos serviços prestados a população. A implantação bem sucedida desse um modelo de gestão de desempenho garantirá um maior comprometimento de toda a máquina pública municipal com os resultados da prefeitura, aumentando significativamente nossas chances de atingir as metas propostas à sociedade carioca durante o primeiro ano da administração. (Portal Secretaria da Casa Civil ${ }^{20}$ ).

Os Acordos de Resultados assinados pelos Secretários e o Prefeito, na gestão anterior, eram revalidados anualmente. Neles, as Secretarias tinham como obrigação cumprir as metas estabelecidas. As Secretarias que cumprissem o acordo/contrato de gestão (notas entre 6 e 10) ao final do ano seriam recompensadas com remuneração fixa e variável.

A parte fixa será devida a todos os servidores elegíveis, correspondendo a um percentual de seu $13^{\circ}$ salário no ano anterior: $10 \%$ (nota 6), 20\% (nota 7), 30\% (nota8), 40\% (nota 9) e 50\% (nota 10). A parte variável será distribuída pelo Secretário / Presidente (dependendo do órgão) segundo critérios meritórios, sendo dois salários o valor máximo total que pode ser pago a um servidor.(...)

Importante: para ter direito a receber a premiação, todo servidor deverá ter trabalhado pelo menos $3 / 4$ do ano nos órgãos que cumpriram as metas." (Portal Secretaria da Casa Civil ${ }^{21}$ ).

No que diz respeito às ações específicas da SME/RJ, em apresentação ${ }^{22}$ realizada pela então secretária de educação do município do Rio de Janeiro ${ }^{23}$, intitulada "Conhecendo a Secretaria Municipal de Educação do Rio de Janeiro", constata-se a diretriz de que é necessário o aprimoramento do processo de ensinoaprendizagem nas escolas da Rede Municipal, desenvolvendo programas, projetos e ações que favoreçam o sucesso escolar de todos os alunos matriculados na rede. Dessa forma, a SME/RJ estabeleceu as seguintes metas para viabilizar o desejado salto na qualidade da educação (quadro 1):

\footnotetext{
${ }^{20}$ Disponível em: http://www.rio.rj.gov.br/web/cvl/exibeconteudo?id=2803400. Acesso em: 16 jan. de 2017.

${ }_{21}$ Disponível em: http://www.rio.rj.gov.br/web/cvl/exibeconteudo?article-id=1820528. Acesso em: 16 jan. 2016.

${ }^{22}$ A apresentação teve como tema "A gestão de políticas públicas e a Educação no Rio de Janeiro" e o acesso ao PPT foi em Janeiro de 2012.

${ }^{23}$ Tal secretária conduziu a gestão da Secretaria Municipal de Educação do Rio de Janeiro entre janeiro de 2009 e abril de 2014, quando assumiu a diretoria de educação do Banco Mundial.
} 
Quadro 1: Metas estabelecidas pela SME/RJ (2011)

- obter uma nota média igual ou superior a 5,1 para os anos iniciais e a 4,3 para os anos finais no Ideb em 2011;

- criar 30.000 novas vagas em creches públicas ou conveniadas até 2012;

- garantir que pelo menos 95\% das crianças com 7 anos de idade ao final do ano de 2012 estejam alfabetizadas;

- reduzir para menos de 5\% a taxa de analfabetismo funcional entre os alunos do $4^{\circ}$ ao $6^{\circ}$ ano, em 2012 ;

- reduzir para menos de $10 \%$ o número de alunos com defasagem idade/série no $6^{\circ}$ ano em 2012.

Fonte: Secretaria Municipal de Educação do Rio de Janeiro (2011)

As metas estabelecidas acima não são iniciativas isoladas. Tais ações encontram-se em consonância com medidas estabelecidas em âmbito nacional pelo Governo Federal e em âmbito internacional por órgãos como a Organização das Nações Unidas para Educação, Ciência e Cultura (Unesco), o Fundo das Nações Unidas para a Infância (Unicef) e o Banco Mundial, como apresentado a seguir.

A tendência em melhorar os resultados vai ao encontro do esforço nacional que visa o progresso do Ideb para que, até 2021, com divulgação em 2022, todas as escolas públicas tenham, no mínimo, nota 6,0 (média dos países da Organização para a Cooperação e Desenvolvimento Econômico - OCDE). Além disso, segundo Maroy e Voisin (2013), uma das características da new accountability é a prestação de contas não só dos recursos e processos escolares, mas, sobretudo, dos resultados dos alunos que são avaliados.

$\mathrm{O}$ atendimento em creches e pré-escolas já é um direito social das crianças firmado desde a Constituição de 1988; logo, a ampliação do número de vagas proposto pela SME/RJ viabiliza o cumprimento legal que estabelece a educação infantil como dever do Estado com a Educação. Outro aspecto que respalda a importância dessa oferta são as pesquisas como a de Campos (1997), que relata a relevância da educação infantil ao demonstrar que alunos que frequentaram esse segmento apresentam melhores desempenhos em longo prazo.

Pesquisadores, como Ruben Klein (2006), ressaltam que para acontecer a conquista da universalização do ensino médio é necessário que as taxas de repetência sejam menores do que 5\%, havendo um ajuste no fluxo escolar. Esse anseio pela correção da distorção idade-série também pode ser explicado pela lógica da eficiência do uso dos recursos públicos, já que, quando há muita 
repetência, há um gasto grande para manter um número elevado de alunos cursando a mesma série, além de um aumento do risco de evasão escolar.

Por fim, outro aspecto que reforça as ações da Secretaria Municipal de Educação do Rio de Janeiro é a divulgação das avaliações externas, apresentando resultados abaixo do esperado em muitas redes estaduais e municipais brasileiras, tocando, portanto, constantemente na questão da alfabetização precária e problemas consecutivos em leitura e interpretação de questões.

Todas essas ações estão embasadas pelo Plano de Metas Compromisso Todos pela Educação, em que a União, os Estados, o Distrito Federal e os Municípios, em regime de colaboração, contando com o apoio das famílias e da comunidade, atuam em busca da melhoria da qualidade da educação básica. Assim como outros municípios, o Rio de Janeiro aderiu ao Compromisso e segue um conjunto de 28 diretrizes, tais como: (i) estabelecer como foco a aprendizagem, apontando resultados concretos a atingir; (ii) alfabetizar as crianças até, no máximo, os oito anos de idade, aferindo os resultados por exame periódico específico; (iii) acompanhar cada aluno da rede individualmente, mediante registro da sua frequência e do seu desempenho em avaliações, que devem ser realizadas periodicamente; (iv) combater a repetência, dadas as especificidades de cada rede, pela adoção de práticas como aulas de reforço no contra turno, estudos de recuperação e progressão parcial ${ }^{24}$.

Dentre as ações desenvolvidas para o ensino fundamental da modalidade regular, destaca-se o Projeto "Reforço Escolar". É parte desse Projeto a elaboração de Orientações Curriculares organizadas por bimestre; a elaboração de Cadernos Pedagógicos bimestrais de apoio pedagógico para professor e aluno; a elaboração e desenvolvimento de projetos e ações como, por exemplo, a Educopédia - plataforma digital com conteúdos de todas as disciplinas); a capacitação de professores; a elaboração e aplicação de avaliações internas bimestrais (Provas da Rede) e externas (Prova Brasil, Prova Rio e AlfabetizaRio); análise de dados e divulgação de resultados (avaliação da eficácia das políticas).

\footnotetext{
${ }^{24}$ Disponível em: http://portal.mec.gov.br/arquivos/pdf/diretrizes_compromisso.pdf. Acesso em: 28 fev. 2017.
} 
De acordo com o material apresentado pela então secretária de educação e divulgado no site da SME/RJ (RIO DE JANEIRO, 2009 25 ), uma política pública eficaz se caracteriza, dentre outros elementos, pela fixação de metas mensuráveis, a partir dos descritores dos problemas (produtos x resultados); interlocução com os públicos relevantes e envolvimento; monitoramento e avaliação do processo e dos produtos, resultados e impactos. Além disso, a então secretária ressaltou que o que tem ajudado a educação como política pública é a presença de alguns fatores como: construir um bom sistema de incentivos; manter foco nos resultados a alcançar; atualizar-se no tema e assegurar a capacitação de todos os envolvidos; divulgar sistematicamente etapas do processo e resultados, mesmo que negativos; ser obsessivo ${ }^{26}$.

Buscando alcançar as metas divulgadas, em 2009 foi lançado o "Prêmio Anual de Desempenho Escolar", criado para valorizar e incentivar o trabalho dos profissionais de educação do município, constituindo um sistema de avaliação e bonificação baseado na meritocracia. Para participar do Projeto, diretores de todas as escolas da rede municipal assinaram um termo de compromisso que fixava as metas a serem alcançadas por cada unidade escolar. Pelas normas, as escolas tiveram que aprimorar seus desempenhos no Ideb.

A primeira premiação aconteceu em 2010, sendo contemplados 4.696 professores, 1.558 servidores e 1.798 duplas regências, de 290 escolas da rede que atingiram as metas estabelecidas no Termo de Compromisso de Desempenho de 2009. No entanto, uma vez que o Ideb é medido a cada dois anos, a Secretaria Municipal de Educação do Rio de Janeiro desenvolveu o Índice de Desenvolvimento da Educação do Rio de Janeiro (IDE-Rio), calculado a partir dos resultados da Prova Rio, que aferia, inicialmente, os conhecimentos dos alunos dos $3^{\circ}$ e $7^{\circ}$ anos em Leitura e Matemática. O IDE-Rio foi lançado em maio de 2009 baseado no Ideb, possibilitando que o pagamento do prêmio seja feito anualmente. Logo, em anos pares, os professores e demais funcionários da educação ligados à SME/RJ recebem o prêmio com base nos resultados do Ideb e, em anos ímpares, com base nos resultados do IDE-Rio.

\footnotetext{
${ }^{25}$ Projeto Salto de Qualidade na Educação Carioca. Rio de Janeiro, 2009. Disponível em: http://www.rio.rj.gov.br/web/sme. Acesso em: 14 jul. 2012.

${ }^{26}$ Os termos foram preservados de acordo com a apresentação da ex-secretária.
} 
Nas informações disponibilizadas no site da SME/RJ e no $\mathrm{G} 1^{27}$, constatase que o IDE-Rio de 2010 apresentou um crescimento de $7 \%$ nos anos iniciais e $14 \%$ nos anos finais em relação a 2009, e 513 escolas atingiram as metas do Termo de Compromisso de Desempenho.

É evidente que o número de escolas que atingiram as metas foi maior do que na avaliação anterior. Esse tipo de iniciativa, tomada pela SME, é uma das características do que os acadêmicos, que se esforçam no entendimento das políticas públicas educacionais, convencionaram chamar, internacionalmente, de accountability. Segundo Brooke (2006),

os ingredientes básicos dos sistemas de responsabilização implantados durante as últimas décadas, tanto nos Estados Unidos quanto em outros países, são quatro: 1. a decisão por parte das autoridades de tornar públicas as diferenças de nível de desempenho das escolas (ingrediente autoridade); 2. o uso de testes ou procedimentos padronizados para fornecer este tipo de informação (ingrediente informação); 3. os critérios para analisar esta informação e para determinar quais escolas têm melhor desempenho (ingrediente padrões); 4. os critérios para a aplicação de incentivos ou sanções conforme os padrões estabelecidos (ingrediente consequências). (p. 379-380).

Alguns autores, como Hanusheck e Raymons (2004), defenderam em suas pesquisas que medidas de responsabilização geram melhorias nos resultados dos alunos matriculados em escolas classificadas como de baixo desempenho.

Brooke (2013) afirmou que as pesquisas sobre accountability, efetivadas em países comparáveis ao Brasil, mostram uma tendência positiva como, por exemplo, ganhos na aprendizagem dos alunos. $\mathrm{O}$ autor defende que, a partir da comparação de escolas semelhantes por meio dos resultados das avaliações, é possível identificar as escolas que apresentam dificuldades em realizar seu trabalho com eficácia e aquelas que podem servir como fonte de aprendizagem para as outras.

Nóvoa (2006) ressaltou que transparência, rigor e prestação de contas podem ser instrumentos utilizados pelos docentes e seus pares e toda a comunidade escolar visando o aprimoramento do trabalho desenvolvido.

Achamos que avaliar tem a ver com controle, com mecanismos e dispositivos de controle político, com agendas políticas diversas. E na verdade, muitas vezes tem. Mas o problema é que nas sociedades de hoje, seja em que patamar for, não se pode deixar de ter uma dinâmica de abertura das profissões, uma dinâmica de

\footnotetext{
${ }^{27}$ Disponível em: http://g1.globo.com/rio-de-janeiro/noticia/2011/05/ide-rio-mostra-melhora-nasnotas-de-alunos-das-escolas-municipais.html . Acesso em: 28 fev. 2017.
} 
transparência, de rigor, de prestação de contas. E essa dinâmica de avaliação e prestação de contas é, em primeiro lugar, uma dinâmica de prestação de contas para nós mesmos e para os nossos colegas. (p. 16).

No entanto, esse não é um consenso na academia, já que outros autores, como Jacob (2005), demonstraram efeitos colaterais desse tipo de política: professores ajudando seus alunos a responder as provas, a exclusão de alunos com baixo desempenho nos dias das avaliações padrozinadas e algumas escolas e docentes desenvolvem apenas os conteúdos que serão exigidos nessas avaliações.

Fernandes e Gremaud (2009) ratificaram que a literatura destaca potenciais riscos dessa política: o "estreitamento" do currículo, a exclusão de alunos de baixa proficiência e treinamento dos alunos para realizar os testes. Freitas (2013) destacou, ainda, a questão mercadológica, já que há uma gama de empresas que avaliam e outras que atuam no sentido de "consertar" os resultados ruins e essa engenharia de faturamento dificulta a discussão de cunho mais acadêmico e o poder de pesar as decisões a partir dos índices.

Adicionalmente, observa-se o que Donald Campbell (1976) advertiu sobre as políticas de responsabilização, ressaltando que quando se associa um indicador a recompensas ou consequências punitivas pode-se provocar uma corrupção do próprio indicador. Por fim, Freitas (2013) discorreu acerca dos perigos da lógica empresarial dentro das escolas: redução de custos, aumento do número de alunos por turma e precarização do trabalho docente.

Retomando as iniciativas de responsabilização adotadas pela SME/RJ, foi introduzida a Resolução N. ${ }^{\circ}$ 1156, de 15 de setembro de 2011, regulamentando a percepção do Prêmio Anual de Desempenho. O Art. $1^{\circ}$ determina que o prêmio (14 salário) será devido aos servidores lotados e em efetivo exercício por, pelo menos, três quartos da vigência do ano letivo nas Unidades Escolares que atingirem a meta, ressalvados seus titulares, para os quais valerá, como requisito único, o efetivo exercício na unidade premiada.

A mesma resolução também esclarece que o prêmio dado aos servidores lotados e em exercício nas Unidades Escolares integrantes do Programa Escolas do Amanhã ${ }^{28}$ será maior e terá como base $150 \%$ (cento e cinquenta por cento) do

\footnotetext{
${ }^{28}$ O Programa Escolas do Amanhã foi lançado em agosto de 2009, Decreto No 31022 de 24 de agosto de 2009, e, em 17 de novembro de 2010, o Município do Rio de Janeiro, por meio da Secretaria Municipal de Educação, assinou um Termo de Cooperação Técnica com a UNESCO
} 
valor salarial equivalente ao décimo terceiro salário do ano anterior, enquanto nas demais Escolas a base será de 100\% (cem por cento).

Buscando perceber as primeiras consequências decorrentes da adoção de um sistema de metas atrelado à bonificação, apresento a seguir o mapeamento dos resultados das escolas da rede municipal do Rio de Janeiro, que atendem ao segundo segmento do ensino fundamental, no Índice de Desenvolvimento da Educação do Rio de Janeiro (IDE-Rio) em 2012, verificando se houve melhoria nos resultados em relação aos dados de 2010.

A escolha pelas escolas que atendem ao segundo segmento deve-se ao fato de que a média geral do Rio no Ideb é maior no primeiro segmento do ensino fundamental em relação ao segundo segmento. A intenção foi perceber, através de uma análise quantitativa, se o sistema de premiação levou a melhorias no índice.

Para as análises estatísticas aqui apresentadas foi construída uma base de dados no software SPSS (Statistical Package for the Social Sciences - pacote estatístico para as ciências sociais) com informações provenientes da SME acerca dos resultados do IDE-Rio das unidades escolares em 2009, 2010 e 2012. Os dados de 2011 não foram considerados nessa análise porque a premiação foi feita a partir dos resultados do IDEB. Apesar de atualmente existirem onze Coordenadorias Regionais de Educação (CREs), as análises serão apresentadas de acordo com a antiga divisão administrativa (10 CREs) porque os dados, inclusive em 2013, foram divulgados dessa forma.

No IDE-Rio de 2010, em todas as Coordenadorias Regionais de Educação houve uma melhora no desempenho das escolas que atendem aos anos finais do ensino fundamental, sendo que a da $9^{\mathrm{a}} \mathrm{CRE}$ apresentou a melhor performance. No entanto, em três CREs $\left(1^{\mathrm{a}}, 3^{\mathrm{a}}\right.$ e $\left.6^{\mathrm{a}}\right)$ o desvio-padrão aumentou entre as escolas, o que revela um aumento da heterogeneidade (anexo V). Ressalto que nem todas as escolas foram avaliadas em 2009, portanto, não tinham uma meta pré-estabelecida para 2010 e, por isso, o total é de 375 escolas. Desse grupo, 271 unidades escolares alcançaram as metas estabelecidas para 2010.

para sua implementação. Esse acordo perpetuou até dezembro de 2016. A iniciativa abrange 155 unidades, situadas em áreas mais conflagradas da cidade do Rio de Janeiro.

Vale ressaltar que o escopo do programa está diretamente vinculado à melhoria do desempenho escolar e à redução das taxas de abandono e evasão. Para tanto, estabeleceu-se uma rotina de horário integral para a incorporação de novas práticas e atividades extracurriculares, que buscam aproximar as famílias e a comunidade das escolas, prevenir a violência e promover a cultura de paz. Disponível em: http://www.rioeduca.net/programasAcoes.php?id=19. Acesso em: 20 jul. 2017. 
Em relação aos resultados apresentados em 2012, das 389 unidades escolares que atendiam ao segundo segmento naquele ano, 237 atingiram as metas estabelecidas pela SME, sendo 204 premiadas. Essa diferença decorre do fato de que as escolas foram premiadas quando atingiram, pelo menos, 50\% da meta estabelecida e, caso atendessem aos anos iniciais e finais, precisariam atingir, no mínimo, $50 \%$ da meta nos dois segmentos. Com esse dado é possível constatar que o número de escolas que atingiu as metas e foi premiada diminuiu quando comparado com os dados de 2010. Das cento e oitenta e três escolas que não foram premiadas, uma era inelegível ${ }^{29}$ e oitenta e três que atendiam apenas ao segundo segmento não atingiram a meta. Oitenta e nove atendiam aos dois segmentos, sendo que quarenta e cinco não atingiram 50\% da meta proposta aos anos iniciais, dez não atingiram a meta proposta para os anos finais e quarenta e quatro não alcançaram a meta nos anos iniciais e nos finais. As seis escolas restantes ou foram avaliadas pela primeira vez ou deixaram de ser avaliadas em 2012 (tabela 6).

Tabela 6: Razões para a não premiação às escolas que atendiam ao segundo segmento em 2012.

1 inelegível

83 não atingiram a meta (atendiam apenas

183 escolas que atendem ao ao segundo segmento)

segundo segmento e não foram 45 não atingiram $50 \%$ da meta nos anos premiadas iniciais (atendiam aos dois segmentos)

10 não atingiram a meta nos anos finais (atendiam aos dois segmentos) 44 não atingiram as metas nos dois segmentos atendidos

6 escolas ou foram avaliadas pela primeira vez ou deixaram de ser avaliadas.

Fonte: Elaboração própria.

Com base nesses resultados, buscando analisar o impacto inicial das medidas de responsabilização adotadas, já é possível constatar um efeito colateral das políticas de accountability exercidas pela SME/RJ. Escolas que apresentam os dois segmentos do ensino fundamental precisam chegar às metas propostas tanto

\footnotetext{
${ }^{29}$ Na planilha divulgada pela SME não havia explicação para a inelegibilidade. Ao visitar o site da SME, não havia informações sobre as características dessa escola, o seguimento atendido, o número de salas e nem sobre o turno de funcionamento. Além disso, não consta na listagem do MEC no portal Ideb.
} 
nos anos iniciais quanto nos anos finais para que toda a equipe receba a bonificação. Tal fato pode provocar um clima de tensão no interior dessas escolas caso um dos segmentos não atinja a meta proposta. A equipe que atinge a meta pode julgar que foi prejudicada pela outra e chegar a um mecanismo maior de pressão no interior do espaço escolar. Por outro lado, a exigência feita pela política ganha sentido quando entendemos que a qualidade educacional precisa ser contínua ao longo da vida escolar do aluno, ou seja, ela não pode ser ofertada apenas por um dos dois segmentos. É claro que também pode existir a possibilidade de parceria entre os diferentes segmentos para que todos os alunos de uma unidade escolar apresentem melhoria na aprendizagem.

Quando comparamos as médias por CRE (tabela 7), é perceptível que em 2012 houve um aumento no desempenho médio das unidades escolares, o que indica um avanço na qualidade educacional proposta pela SME. A sétima CRE apresentou a melhor performance, no entanto, em sete CREs $\left(1^{\mathrm{a}}, 3^{\mathrm{a}}, 6^{\mathrm{a}}, 7^{\mathrm{a}}, 8^{\mathrm{a}}, 9^{\mathrm{a}} \mathrm{e}\right.$ $10^{\mathrm{a}}$ ) o desvio-padrão aumentou entre as escolas, o que revela um aumento da desigualdade quando comparamos com os dados de 2010.

Tabela 7: Desempenho comparativo por CRE (2010 e 2012).

\begin{tabular}{ccccccc} 
CRE & $\begin{array}{c}\text { Média } \\
\mathbf{( 2 0 1 0 )}\end{array}$ & $\begin{array}{c}\mathbf{N} \\
\mathbf{( 2 0 1 0 )}\end{array}$ & $\begin{array}{c}\text { Desvio } \\
\text { padrão } \\
\mathbf{( 2 0 1 0 )}\end{array}$ & $\begin{array}{c}\text { Média } \\
\mathbf{( 2 0 1 2 )}\end{array}$ & $\begin{array}{c}\mathbf{N} \\
\mathbf{( 2 0 1 2})\end{array}$ & $\begin{array}{c}\text { Desvio } \\
\text { padrão } \\
(\mathbf{2 0 1 2})\end{array}$ \\
$\mathbf{1}$ & 3,885 & 20 &, 6699 & 4,679 & 19 &, 7083 \\
$\mathbf{2}$ & 3,981 & 43 &, 8279 & 4,712 & 43 &, 8039 \\
$\mathbf{3}$ & 4,029 & 38 &, 6653 & 4,500 & 38 &, 7128 \\
$\mathbf{4}$ & 3,684 & 58 &, 7476 & 4,354 & 59 &, 6561 \\
$\mathbf{5}$ & 4,030 & 43 &, 6650 & 4,572 & 43 &, 6131 \\
$\mathbf{6}$ & 3,768 & 19 &, 5034 & 4,355 & 20 &, 5296 \\
$\mathbf{7}$ & 4,188 & 43 &, 5993 & 4,747 & 43 &, 6748 \\
$\mathbf{8}$ & 3,785 & 47 &, 5154 & 4,419 & 47 &, 6110 \\
$\mathbf{9}$ & 4,247 & 34 &, 4653 & 4,491 & 34 &, 5119 \\
$\mathbf{1 0}$ & 3,885 & 40 &, 4566 & 4,478 & 41 &, 5659 \\
Total & 3,944 & 385 &, 6525 & 4,525 & 387 &, 6557 \\
\hline
\end{tabular}

Fonte: Elaboração própria.

Os resultados aqui encontrados reforçam o mecanismo de estratificação relacionado com o acesso diferenciado aos recursos escolares, apresentado por 
Alves, Lange e Bonamino (2010), mesmo entre escolas de uma mesma rede e, assim, atingidas por uma política semelhante e destinada à população menos favorecida. Os autores ressaltam que, entre alunos pobres, os mais pobres frequentam as piores escolas, o que geralmente é determinado pela localização do domicílio e do próprio estabelecimento escolar. Segundo Ribeiro e Koslinski (2010), esse tipo de pesquisa, cuja característica é a junção das abordagens da sociologia urbana e da sociologia da educação para tratar dos possíveis efeitos dos contextos sociais conformados pela organização social do território sobre as condições efetivas de escolarização de crianças e jovens, é uma tendência nas últimas décadas.

A eficácia escolar é assunto recorrente no campo educacional e desperta interesse quando se discute políticas que visam uma educação de qualidade. Ainda não existe um consenso do que consiste em uma escola eficaz. No entanto, existe concordância no que se refere à metodologia e à necessidade de enfoque aos resultados dos alunos.

A ênfase da maioria dos estudos sobre eficácia escolar focou no desempenho acadêmico, já que esse é o parâmetro mais importante para verificar a concretização ou não do aprendizado dos alunos. De acordo com Andrade (2008),

equidade não é sinônimo de igualdade; a escola, na qual todos os alunos têm o mesmo resultado, é utopia. O real é composto de diferenças, devido à variação intrínseca do ser humano, mas o que é inaceitável é admitir que o sistema não precise ser justo. Dubet (2004) apresenta uma discussão pertinente sobre o que é uma escola justa. A medida de equidade relaciona-se com a capacidade que cada escola tem para acirrar ou amortecer as diferenças pré-existentes entre o seu grupo de alunos. A variação nos resultados de desempenho dos alunos sempre vai existir, portanto uma escola equitativa é aquela na qual o padrão da variação para a população se repete para os subgrupos, sejam eles sociais, raciais etc. Lee (2001b) coloca a equidade social como sendo relacionada à aprendizagem que não é dependente do contexto social dos alunos. Define-se, portanto, equidade como sendo uma medida da capacidade do sistema (ou de uma escola) de fazer com que o desempenho de seus alunos independa do seu próprio contexto ou de características pré-existentes (p. 30-31).

Os valores do Ideb e do IDE-Rio aumentam quando aumenta o desempenho dos alunos e/ou quando há correção do fluxo. No entanto, ao longo da minha experiência como professora da rede municipal do Rio de Janeiro, muitas vezes, para melhorar o índice, as escolas atuam de modo pouco equitativo, pois agem com grande expectativa junto aos alunos com bom desempenho para 
que os mesmos aumentem ainda mais as suas notas nas avaliações externas e investem menor esforço nos alunos de baixo desempenho. Atualmente, em decorrência da prática de algumas escolas que solicitavam que alunos com baixo desempenho não compareçam à escola no dia da aplicação das avaliações externas, as equipes gestoras precisam assinar um termo de compromisso garantindo uma frequência mínima de $80 \%$.

Quando a análise é feita tendo por base os dados da Prova Brasil de Língua Portuguesa e Matemática, aplicada ao nono ano do ensino fundamental, e os resultados do Ideb, a situação do segundo segmento, ainda que com as políticas de responsabilização, não melhora muito. Desde 2013 a meta estabelecida pelo MEC para a rede municipal do Rio de Janeiro não é atingida (gráfico 1). Tanto na avaliação de Língua Portuguesa quanto na de Matemática, a maior parte dos alunos do nono ano ainda não está no nível adequado. Em Português, 18,2\% dos alunos encontram-se no nível abaixo do básico, 47,74\% no nível básico, 26,66\% no nível adequado e 6,18\% no avançado (gráfico 2). Em Matemática a situação é ainda mais precária, apenas $14,48 \%$ está no nível adequado e 2,65\% está no nível avançado, ou seja, 83,28\% dos estudantes estão nos níveis abaixo do básico ou básico (gráfico 3).

É uma questão ainda a ser respondida de modo mais aprofundado a razão da diferença na evolução do desempenho do primeiro segmento e o não acompanhamento no mesmo ritmo do segundo segmento do ensino fundamental. Além disso, os alunos da rede apresentam melhor desempenho no IDE-Rio em relação ao Ideb. Uma das possíveis explicações, é o elevado índice de reprovações e abandono, já que um dos componentes do índice é o fluxo dos alunos (figura 1).

Gráfico 1: Resultado do Ideb do segundo segmento do ensino fundamental

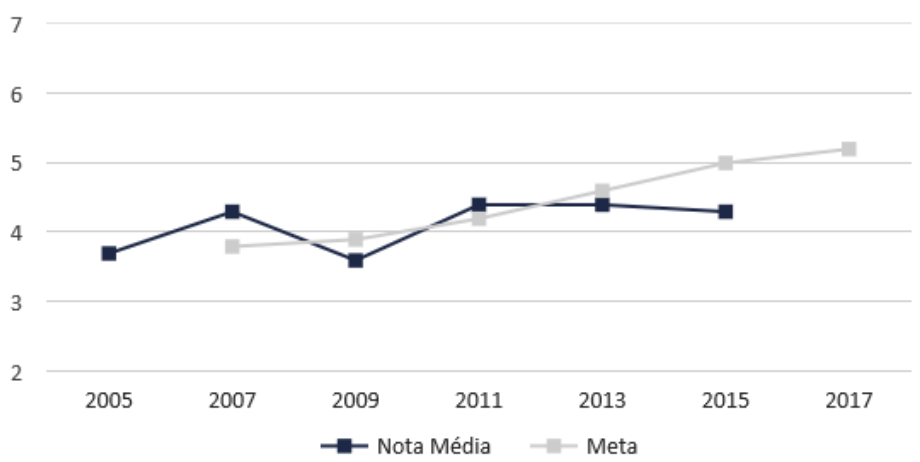

Fonte: Latitude - Educação Georreferenciada (2017) 
Gráfico 2: Desempenho na Prova Brasil - Português (2013)

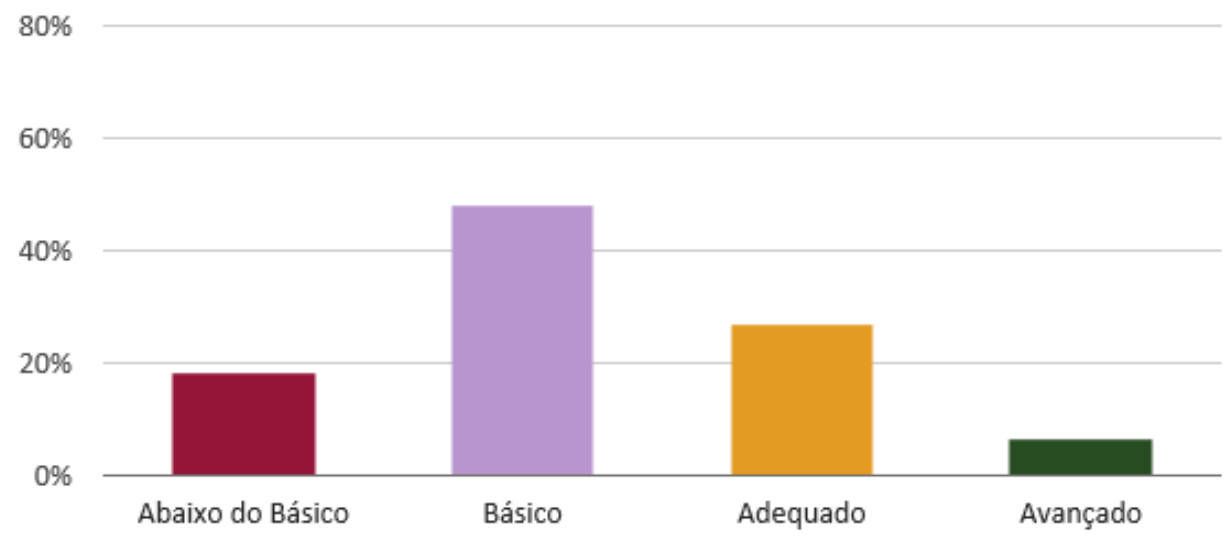

Fonte: Latitude - Educação Georreferenciada (2017)

Gráfico 3: Desempenho na Prova Brasil - Matemática (2013)

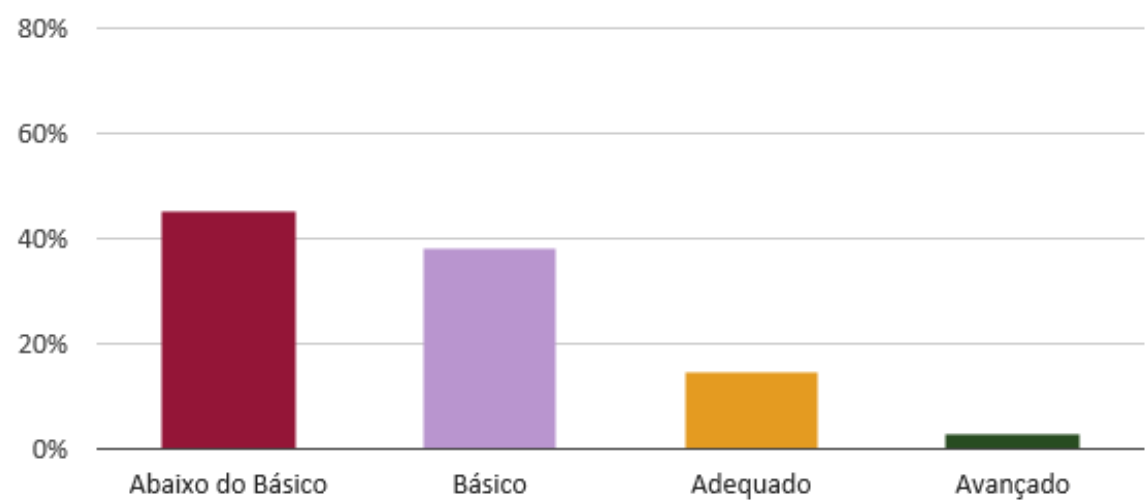

Fonte: Latitude - Educação Georreferenciada (2017)

Figura 1: Indicador de fluxo - proporção de aprovados

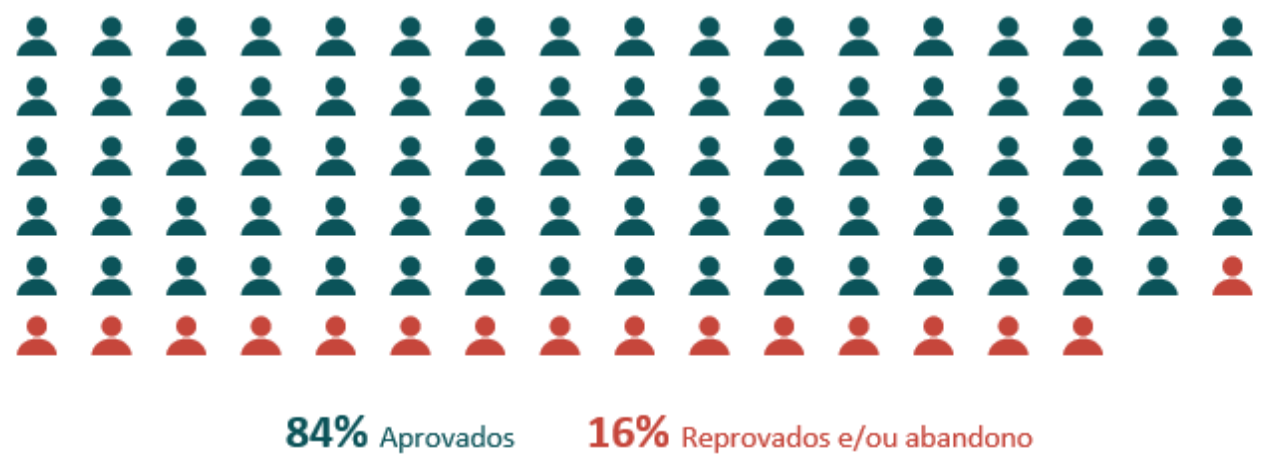

Fonte: Latitude - Educação Georreferenciada $(2017)^{30}$

${ }^{30}$ Com base nos dados do Censo Escolar 2015. 
Através da análise do desempenho nas avaliações da rede educacional do município do Rio de Janeiro, foi possível perceber que as políticas de accountability se apresentam de modo muito mais complexo; no entanto, a discussão na academia tem sido feita de modo fortemente polarizado, como se só pudessem existir impactos negativos ou positivos. Na gestão iniciada em 2009 e encerrada em 2016, a Secretaria Municipal de Educação do Rio de Janeiro conseguiu, de modo geral, aumentar o desempenho das escolas a partir da estipulação de metas e distribuição de bonificações salariais. Contudo, a heterogeneidade entre as escolas das diferentes CREs aumentou, o que já mostra uma ambivalência da política. $\mathrm{O}$ agravamento da desigualdade entre as escolas da rede é um ponto crucial que precisa ser considerado pela política educacional da SME, pois o desempenho apresentado pelos alunos não reflete apenas as diferenças educacionais, mas também as desigualdades sociais e econômicas. Soares e Marotta (2009) argumentam que um sistema educacional é definido como equitativo se qualquer subconjunto de alunos, identificado através de uma característica sociodemográfica, tem a mesma distribuição do respectivo total de alunos.

Retomo autores, como Freitas (2013), que destacaram o quanto e como as políticas de responsabilização, por vezes, podem trazer fortes consequências negativas para dentro das escolas como, por exemplo, o estreitamento curricular e também territorial para conjuntos de escolas, gerando trabalhos especializados em determinadas funções, como, a tarefa de atender os piores alunos de uma região. Segundo Afonso (2002),

os alunos com problemas de comportamento, ou com dificuldades de aprendizagem, tenderão assim a ser excluídos de algumas escolas porque podem afectar a imagem social destas organizações ou, ainda, porque podem sobrecarregar os recursos humanos e materiais disponíveis. (...) Entre outros efeitos, o processo de competição, promovido pela possibilidade prática de realizar escolhas educacionais, tenderá a concentrar em algumas escolas, altamente selectivas, os alunos percepcionados como os melhores. (p. 90-91)

Faz-se necessária, portanto, uma investigação mais aprofundada das práticas escolares, o que pode gerar uma melhor compreensão dos efeitos da política de responsabilização adotada pela SME/RJ.

Outro fator que ainda precisa ser levado em consideração para aprimorar a política de responsabilização é o nível socioeconômico, já que a cidade do Rio de 
Janeiro é muito estratificada. Nem todos os alunos e seus familiares se beneficiam da mesma forma da prestação de contas realizada através da divulgação dos resultados escolares. Há famílias com diferentes redes sociais e capital cultural para se informar sobre as melhores escolas e buscar uma vaga para seus filhos e, assim, há escolas que acabam atraindo os melhores alunos, gerando mais desigualdade na sociedade. Segundo Soares (2005), o nível socioeconômico do aluno é, sabidamente, o fator de maior impacto nos resultados escolares. Esse é um constrangimento real, extraescolar, que pode ajudar ou dificultar o aprendizado e que afeta diretamente o funcionamento e a organização das escolas e das salas de aula. Diminuir as diferenças entre a condição socioeconômica e cultural dos alunos de um sistema de ensino, através de políticas públicas, tem impacto nos resultados cognitivos, mesmo que não imediatamente.

Ainda é um desafio no campo educacional discutir as consequências das políticas públicas de responsabilização, e como as mesmas são incorporadas e ressignificadas no interior das escolas pelos gestores e docentes, enfatizando o quanto as pressões por metas e bonificações podem colaborar na produção de desigualdades sociais, o que seria um efeito colateral negativo.

Fernandes e Gremaud (2009) alertam que uma escola que recebe alunos com escassa bagagem cultural pode realizar um excelente trabalho e, ainda assim, não ter seus alunos entre aqueles com melhores resultados, já que o ranking das escolas reflete pouco o esforço realizado. Além disso, os autores afirmam que os Projetos de accountability deveriam utilizar alguma medida de valor adicionado, pois o desempenho dos estudantes não reflete apenas a qualidade da escola, mas também as condições socioeconômicas dos alunos, sendo necessário decompor os resultados dos alunos em "efeito escola" e "efeito aluno", ainda que não exista um consenso sobre a melhor forma de aferir esses índices.

A rigor, esse tipo de efeito não pode ser pesquisado a partir do padrão de avaliação transversal de coleta simultânea de informações sobre o desempenho dos alunos e das condições da escola. O problema com esse padrão reside no fato da aprendizagem ser um processo cumulativo, construído ao longo da trajetória educacional do aluno, e fruto de diversas influências; ou seja, é difícil precisar o ponto de partida dos alunos e as contribuições específicas do ambiente de aprendizagem. 
As opiniões se dividem em relação aos instrumentos e metodologias para verificar a qualidade do ensino. Segundo Almeida (2013),

No Brasil, quase todas as avaliações externas padronizadas buscam um diagnóstico acerca do sistema educacional com objetivo de verificar a qualidade em todos os níveis de ensino e subsidiar as políticas públicas (Gatti, 2009; Krasilchik, 2001; Pipolo, 2010; Sobrinho, 2005; Carrasco \& Torrecilla, 2009). Tais iniciativas geram muitos debates no campo acadêmico sem que haja consenso entre aqueles que são a favor e os que são contra este tipo de avaliação, revelando as tendências opostas que têm balizado o debate nos últimos anos. Este debate reverbera no interior das escolas, onde gestores e professores lidam com as avaliações, se apropriam de sua dinâmica específica e tentam compreender como as mesmas interferem no seu trabalho. Muitos destes atores se identificam com discursos contrários às avaliações uma vez que têm o sentimento de perda da autonomia. Embora não haja consenso nos debates e seus argumentos sejam variados, observamos que as críticas, a desconfiança e as acusações têm destaque na literatura acadêmica do campo educacional. (p. 34).

Parte das críticas às avaliações externas com exames padronizados referese aos limites do instrumento, uma vez que componente significativo do sucesso escolar é explicado, por exemplo, pelo background familiar do aluno, ou seja, por fatores extraescolares. Contudo, em estudos recentes, pesquisadores cruzam as informações acerca do desempenho do aluno com os dados escolares e sociodemográficos, buscando entender o contexto. Esses dados podem ser obtidos através dos questionários aplicados nos dias das avaliações e, logo, o desenho dos instrumentos permitiu mitigar tais críticas. Ainda assim, faltam mais dados relacionados à cultura organizacional no interior das unidades escolares, tais como as condições de trabalho e as relações de poder. Vale destacar, ainda, a queixa de que apenas duas disciplinas são avaliadas (Matemática e Língua Portuguesa) e nas avaliações não são considerados elementos relacionados à cultura e ao esporte como, por exemplo, as aulas de artes plásticas, música e educação física.

Pesquisas como as realizadas por Ingram, Louis e Schroeder (2004) revelam que vários professores descreveram situações em que sentiram que os dados gerados através das avaliações foram mal utilizados ou não utilizados, sugerindo que os professores veem como prática comum a omissão ou distorção de dados. Para Carrasco e Torrecilla (2009), rendimento escolar não é sinônimo de qualidade educativa, alegando que "não é possível falar de qualidade em educação se os alunos não se apropriarem das aprendizagens necessárias a um desenvolvimento integral e a uma participação plena e igualitária na sociedade" (p. 42). Oliveira e Araújo (2005) afirmam que a "aferição da qualidade ainda 
encontra muita resistência entre os profissionais da educação, porque não faz parte da nossa história e da nossa cultura educacional pensar a qualidade enquanto medida" (p. 12).

Em sua pesquisa, Almeida (2013) investigou, utilizando a metodologia de grupos focais, as impressões de 36 professores lotados no estado do Rio de Janeiro - 22 do município de Duque de Caxias e 14 da cidade do Rio de Janeiro -, com o objetivo de identificar o grau de apropriação e conhecimento que os mesmos detêm acerca dos sistemas de avaliação e identificar casos de aprimoramento no desempenho docente e casos de resistência em relação à implantação dessas políticas. A autora concluiu que

\begin{abstract}
Ao discorrerem sobre as avaliações externas, os docentes revelam sentimentos de orgulho com a profissão, mas também de apreensão, revolta e culpa. Estes sentimentos estão atrelados à percepção de que estão sendo mais cobrados pela sociedade para que os alunos elevem seu desempenho, mesmo que as condições de trabalho não sejam favoráveis em termos materiais e humanos. Os professores não se colocaram contra a avaliação nem a divulgação pública dos resultados, mas ressaltaram que se sentiam criticados pelo trabalho desenvolvido e pelo esforço empreendido frente as condições de trabalho que encontram nas escolas, e também pelos alunos que possuem, os quais muitas vezes não demonstram interesse em realizar as provas ou não sabem realizar provas de múltipla escolha ou, ainda, encontram-se muito defasados cognitivamente. (ALMEIDA, 2013, p. 93).
\end{abstract}

Como discutido anteriormente, apesar das inúmeras críticas, vários autores percebem que o sistema de avaliação externa por meio de testes padronizados possibilita o desenvolvimento e aprimoramento de políticas públicas educacionais, cooperando para a aprendizagem e o sucesso escolar através de ações pedagógicas tomadas a partir de informações produtoras de sentido. Como afirma Pipolo (2010), os resultados das avaliações são dados úteis acerca do desempenho dos diferentes sistemas educacionais e das unidades escolares, possibilitando a identificação de dificuldades e limitações, mas também a percepção de potencialidades, soluções e práticas eficientes e, assim, auxiliam no planejamento e na formulação de políticas públicas.

De acordo com Souza (2007),

o papel justamente dessas avaliações, como comentado, é o de levantar informações que possam ser úteis na administração das redes/sistemas de ensino, pois o que a avaliação faz é identificar aspectos da prática pedagógica já desenvolvida e mostrar de que forma essa prática tem ou não problemas. Cumpre aos administradores do sistema de ensino e das escolas, de um lado, lerem essas informações com olhares criteriosos de sorte a conhecer melhor o panorama apontado pelas avaliações e, de outro, encontrarem formas de minimizar os efeitos 
(e disfunções?) promovidos pela própria avaliação, os quais podem distorcer aquela leitura mais aprofundada da realidade educacional (...). Porém, o objetivo de uma avaliação desta natureza não é o de mostrar o perfil de desempenho pedagógico de cada um dos alunos ou das escolas nas quais as provas são aplicadas, de maneira isolada, mas o de estabelecer perfis pedagógicos mais ampliados, por estados ou por regiões geoeducacionais. (p. 65-6)

Os argumentos presentes no campo acadêmico refletem a falta de consenso no campo da avaliação educacional e, consequentemente, os diferentes discursos também ecoam no interior das escolas, interferindo no cotidiano dos seus atores e na(s) representação(ões) que giram em torno do conceito de qualidade educacional.

Nesta perspectiva, Oliveira e Araújo (2005) ressaltam que o grande desafio atual, no que diz respeito ao direito à educação,

[...] é fazer com que ele seja, além de garantido e efetivado por meio de medidas de universalização do acesso e da permanência, uma experiência enriquecedora do ponto de vista humano, político e social, e que consubstancie, de fato, um projeto de emancipação e inserção social. Portanto, que o direito à educação tenha como pressuposto um ensino básico de qualidade para todos e que não produza mecanismos de diferenciação e exclusão social. (p. 3)

Em meio a tantas ambivalências quanto aos benefícios e prejuízos no que tange às avaliações e políticas de responsabilização docente, não seria o momento de investigar as ações voltadas à formação cultural dos alunos, recortando aqui para o contexto da rede municipal do Rio de Janeiro e, através de dados empíricos, enriquecer o debate?

Vários autores, como apresentado anteriormente, defendem que os resultados das avaliações podem se configurar como recurso valioso para o direcionamento de políticas públicas educacionais, permitindo que as ações desenvolvidas sejam tomadas no sentido da promoção de equidade.

Durante o desenvolvimento da pesquisa aqui apresentada, busquei encontrar alguma ação desenvolvida pela SME que fizesse uso dos resultados das avaliações. Foi então possível constatar a construção de uma ponte para a equidade através de um setor técnico-educativo responsável pelo acompanhamento pedagógico de projetos que buscam tanto a permanência dos alunos nas escolas quanto a melhora acadêmica. $\mathrm{O}$ mais interessante foi notar que 
uma das matérias primas principais para a construção dessa ponte era um Projeto com base na formação cultural dos alunos: o Projeto Escola e Museu.

Por mais que as discussões no âmbito das avaliações externas estejam atreladas aos acordos de responsabilização docente e, infelizmente, no interior das escolas, as discussões passem pelo sentimento de pressão para que sejam alcançadas as metas e as premiações, a SME do Rio de Janeiro, desde 2013, desenvolve um Projeto que tem um olhar diferenciado para os alunos pertencentes aos ginásios experimentais ${ }^{31}$, para as escolas com baixo desempenho e/ou situadas em áreas conflagradas, buscando, através da experiência cultural, construir novas oportunidades de aprendizagem.

Como explicitado anteriormente, a abordagem quantitativa realizada com os dados sobre desempenho até 2012 pretendiam revelar o efeito inicial das políticas de responsabilização docente adotas pela SME. Foi possível notar uma melhoria no desempenho dos alunos do primeiro e segundo segmentos do ensino fundamental. No entanto, tal condição não é mantida nas avaliações do MEC, através da Prova Brasil e do Ideb.

Figura 2: Evolução e Ideb atual do segundo segmento do ensino fundamental

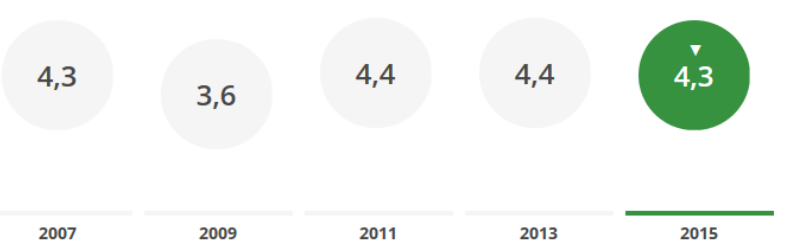

Fonte: QEdu Redes ${ }^{32}$ (2017).

\footnotetext{
${ }^{31}$ Novo modelo de ensino para as escolas de segundo segmento $\left(6^{\circ}\right.$ ao $9^{\circ}$ Anos) da Prefeitura do Rio, o Ginásio Carioca vem transformando a realidade de cerca de 250 mil alunos. Implantando pela Secretaria Municipal de Educação em 2011, o programa é sustentando em três eixos excelência acadêmica, apoio ao projeto de vida do aluno e educação para valores, conta com uso das novas tecnologias e de materiais didáticos estruturados por apostilas de conteúdo e exercícios e já mostra resultados, diminuindo a defasagem idade/série e a evasão escolar. Além disso, dentro desse novo programa, os professores e alunos contam com mais uma ferramenta de ensino, a Educopédia: uma plataforma de aulas digitais de cada disciplina, com material de suporte aos professores, planos de aula, jogos pedagógicos e vídeos. Dentro do programa, a Prefeitura criou também o Ginásio Experimental para alunos do $7^{\circ}$ ao $9^{\circ}$ Anos. Adotado em 10 escolas da Prefeitura em 2011, o projeto foi ampliado para mais nove unidades em 2012, atendendo a mais de sete mil alunos. Nessas unidades, os alunos estudam em horário integral, têm mais tempos de aulas de Português, Matemática, Ciências e Inglês, contam com salas temáticas e com professores em dedicação exclusiva e têm uma biblioteca com acervo atraente e adequado aos adolescentes. Pelo projeto, os alunos são acompanhados por um professor tutor, que os auxilia na construção de um projeto de vida. Disponível em: http://www.rioeduca.net/programasAcoes.php?id=29. Acesso em: 21 jul. 2017.

${ }^{32}$ Disponível em: http://redes.qedu.org.br/minha-rede/. Acesso em: 21 jul. 2017.
} 
Esse era o contexto em que a rede municipal de educação do Rio de Janeiro estava inserida durante a gestão do prefeito em exercício no período de 2009 a 2016. Falar das avaliações externas e das políticas de responsabilização docente nesta tese foi necessário para esclarecer as características do momento vivenciado durante a pesquisa de campo e também porque o Projeto Escola e Museu faz uso desses resultados como critério para a escolha das escolas que comporão o grupo que participará das atividades propostas.

É imprescindível pensar que jovens em situação de analfabetismo funcional e com o aprendizado comprometido nas mais diversas disciplinas, como mostram os dados relacionados ao desempenho do segundo segmento, são pessoas que, para além de excluídas de possibilidades qualificadas de inserções no mercado de trabalho, também podem ser apartadas do acesso às produções da humanidade como, por exemplo, a cultura.

Nesta perspectiva, pelo menos em tese, o Projeto Escola e Museu configura-se como uma ação diferenciada por permitir a esses jovens o contato com a dimensão estética, na tentativa de sensibilizá-los de modo crítico e, assim, fazer com que eles tenham auto compreensão, estimulando a formação cultural e também a formação acadêmica. Segundo Habermas (1992, p.119),

a experiência estética não renova apenas as interpretações das necessidades, à luz das quais percebemos o mundo; interfere, ao mesmo tempo, também nas explicações cognitivas e expectativas normativas, modificando a maneira como todos esses momentos remetem uns aos outros.

É possível notar que Habermas defende a associação entre a experiência estética (arte/cultura), as expectativas normativas (ética) e as interpretações cognitivas (ciências). A associação entre esses três campos, apesar de não estar explícita nos documentos oficiais do Projeto Escola e Museu, é uma forte premissa, pois cabe ao setor responsável pelo projeto colaborar com a melhoria do desempenho dos alunos e sua permanência na escola e, no caso discutido ao longo da tese, a estratégia adotada é a oferta e o acesso à experiência estética em museus e centros culturais.

A instituição escolar continua sendo a referência de espaço educativo, no entanto, ela não é o único espaço e, por vezes, nem o mais adequado para alguns 
processos de formação. Trilla (2008) elenca alguns fatos que questionam a vinculação entre educação e escolarização:

O marco institucional e metodológico da escola nem sempre é o mais idôneo para atender a todas as necessidades e demandas educacionais. A estrutura escolar impõe limites que devem ser reconhecidos. E mais: além de não ser apta para todo tipo de objetivo educacional, a escola mostra-se particularmente imprópria para alguns deles. Do ponto de vista anterior deriva a necessidade de criar paralelamente à escola, outros meios e ambientes educacionais. Meios e ambientes que, claro, não devem ser vistos necessariamente como opostos ou alternativos à escola, mas como funcionalmente complementares a ela. Esses recursos são, em grande medida, justamente aqueles que a partir de certo momento passaram a ser chamados de "não formais". (p. 18-19).

Para apresentar o Projeto Escola e Museu e explicitar a parceria que ocorre entre essas duas esferas educativas, são necessárias algumas discussões prévias, apresentadas a seguir, acerca de cultura, formação cultural, espaços não formais de educação e políticas culturais no Brasil e no âmbito da prefeitura do Rio de Janeiro. 


\subsection{Cultura, formação cultural e os espaços de educação não formal}

Muito se discute acerca da dimensão da formação acadêmica na educação. No entanto, esta tese propõe ampliar o olhar acerca da formação através da análise da dimensão da formação cultural. Pensar sobre a formação cultural exige primeiramente uma breve reflexão acerca do conceito de cultura. Este é um conceito definido de vários modos, assumindo diferentes sentidos ao longo do tempo.

Segundo o dicionário Michaellis ${ }^{33}$, cultura pode significar: 1 (agronomia) Ato, processo ou efeito de trabalhar a terra, a fim de torná-la mais produtiva; cultivo, lavra; 2 (agronomia) Ato de semear ou plantar vegetais; 3 (agronomia) A área cultivada de um sítio, 4 (agronomia) Produção agrícola com técnicas especiais; cultivo; 5 (biologia) Ato de cultivar células ou tecidos vivos numa solução com nutrientes, em condições adequadas, a fim de realizar estudos científicos; 6 Criação de determinados animais; 7 (antropologia) Conjunto de conhecimentos, costumes, crenças, padrões de comportamento, adquiridos e transmitidos socialmente, que caracterizam um grupo social; 8 Conjunto de conhecimentos adquiridos, como experiências e instrução, que levam ao desenvolvimento intelectual e ao aprimoramento espiritual; instrução, sabedoria; 9 Requinte de hábitos e conduta, bem como apreciação crítica apurada. Muitas destas definições não se alinham com o conceito cultural trabalhado na área da sociologia e da antropologia, sendo então necessário aprofundar o sentido da palavra, bem como a mesma se relaciona com a formação cultural e os espaços de educação não formal.

Da Matta (1981, p.4) apresenta os dois sentidos mais comuns do termo: (i) usa-se cultura como sinônimo de sofisticação, enfatizando um certo estado educacional das pessoas, podendo servir como arma discriminatória para classificá-las; (ii) aplica-se como um conceito chave para a interpretação da vida social, ou seja, a maneira de viver total de um grupo, sendo um bom instrumento para compreender as diferenças entre os homens e as sociedades. $\mathrm{O}$ autor assume que

\footnotetext{
${ }^{33}$ Disponível em: http://michaelis.uol.com.br/busca? $\mathrm{r}=0 \& \mathrm{f}=0 \& \mathrm{t}=0 \&$ palavra=cultura. Acesso em: 28 de fevereiro de 2017.
} 
o conceito de cultura, ou, a cultura como conceito, então, permite uma perspectiva mais consciente de nós mesmos. Precisamente porque diz que não há homens sem cultura e permite comparar culturas e configurações culturais como entidades iguais, deixando de estabelecer hierarquias em que inevitavelmente existiriam sociedades superiores e inferiores. Mesmo diante de formas culturais aparentemente irracionais, cruéis ou pervertidas, existe o homem a entendê-las ainda que seja para evitá-las, como fazemos com o crime - é uma tarefa inevitável que faz parte da condição de ser humano e viver num universo marcado e demarcado pela cultura. Em outras palavras, a cultura permite traduzir melhor a diferença entre nós e os outros e, assim fazendo, resgatar a nossa humanidade no outro e a do outro em nós mesmos.

Em conformidade com o segundo sentido apresentado por Da Matta (1981), Hall (1997) explica que

a princípio, cultura se relaciona com a produção e a troca de significados - o dar e receber significados - entre os membros de uma sociedade ou o grupo. Dizer que duas pessoas pertencem à mesma cultura, é dizer que elas interpretam o mundo aproximadamente da mesma forma e podem expressar seus pensamentos e sentimentos sobre o mundo de maneiras que serão entre elas compreendidas. Assim a cultura depende da interpretação significativa de seus participantes sobre o que está em torno deles, e o 'fazer sentido' do mundo, de maneira semelhante. (p. 2).

Ora, a cultura é então um elemento que confere a essência, a identidade dos indivíduos e, justamente por isso, é um direito de todo cidadão brasileiro, conforme exposto na Constituição Brasileira:

Art. 215. O Estado garantirá a todos o pleno exercício dos direitos culturais e acesso às fontes da cultura nacional, e apoiará e incentivará a valorização e a difusão das manifestações culturais.

$\S 1 .^{\circ} \mathrm{O}$ Estado protegerá as manifestações das culturas populares, indígenas e afrobrasileiras, e das de outros grupos participantes do processo civilizatório nacional.

$\S 2 .^{\circ}$ A lei disporá sobre a fixação de datas comemorativas de alta significação para os diferentes segmentos étnicos nacionais. (BRASIL, 1988).

O direito à cultura também é garantido pela Lei de Diretrizes e Bases da Educação Nacional 9394/96. Em seu Art. 1. define que "A educação abrange os processos formativos que se desenvolvem na vida familiar, na convivência humana, no trabalho, nas instituições de ensino e pesquisa, nos movimentos sociais e organizações da sociedade civil e nas manifestações culturais”.

Para que haja o pleno exercício desse direito é preciso que o cidadão tenha acesso a uma formação cultural de qualidade também na esfera escolar. Muitas vezes tal acesso é viabilizado através das visitas escolares aos museus e a outros 
equipamentos culturais. Vale destacar que a metodologia utilizada nesses espaços não formais de educação se distancia das formas convencionais da escola, situando-se fora do sistema de ensino regrado e sem estar diretamente voltado à outorga de certificação.

A educação formal compreenderia o sistema educacional altamente institucionalizado, cronologicamente graduado e hierarquicamente estruturado que vai dos primeiros anos da escola até os últimos anos da universidade; a educação não-formal, toda atividade organizada, sistemática, educativa, realizada fora do marco do sistema oficial, para facilitar determinados tipos de aprendizagem a subgrupos específicos da população, tanto adultos como infantis. (Coombs, 1985, p.46).

Considerando-se que a função social dos museus tem mudado no curso da história, percebe-se assim que o seu conteúdo tem se diversificado, bem como a sua missão, sua forma de funcionamento e sua administração. De acordo com Nascimento Júnior e Chagas (2006)

na segunda metade do século XX, ou, de modo mais preciso, depois dos anos setenta, a museologia e os museus no Brasil passaram por um grande processo de transformação e amadurecimento. Nesse período, o objeto de estudo da museologia foi construído, desconstruído e reconstruído inúmeras vezes; a categoria museu foi ressignificada e a diversidade tipológica dos museus foi ampliada de uma maneira sem precedentes. Os museus passaram a ser tratados como processos e práticas culturais de relevância nacional. (p.14).

A maioria dos países estabelece definições de museu por meio de textos legislativos ou por intermédio de suas organizações nacionais. A definição de museu mais difundida, desde 2004, é a apresentada pelo Estatuto do Conselho Internacional de Museus (ICOM).

Museu é uma instituição permanente, sem fins lucrativos, a serviço ${ }^{34}$ da sociedade e de seu desenvolvimento, que adquire, conserva, pesquisa divulga e expõe, para fins de estudo, educação e lazer, testemunhos materiais e imateriais dos povos e seu meio ambiente.

De acordo com a Lei $\mathrm{n}^{\circ} 11.904$, de 14 de janeiro de 2009, que instituiu o Estatuto de Museus,

consideram-se museus, para os efeitos desta Lei, as instituições sem fins lucrativos que conservam, investigam, comunicam, interpretam e expõem, para fins de

${ }^{34}$ É preciso explicitar que o uso das expressões "estar a serviço" e "atendimento", quando relacionadas à educação não formal e aos equipamentos culturais, não é um consenso no campo educacional e da museologia. No entanto, o uso foi mantido nesta tese por serem expressões utilizadas pelo Estatuto do Conselho Internacional de Museus (ICOM). 
preservação, estudo, pesquisa, educação, contemplação e turismo, conjuntos e coleções de valor histórico, artístico, científico, técnico ou de qualquer outra natureza cultural, abertas ao público, a serviço da sociedade e de seu desenvolvimento. (IBRAM, 2009).

Para Grinspum (2001, p. 2), o compromisso sociopolítico dos museus é, antes de tudo, educacional, e sua nova definição aponta para "instituições de serviço público e educação, um termo que inclui exploração, estudo, observação, pensamento crítico, contemplação e diálogo".

Na subseção II, Art. 29, é estabelecido que "os museus deverão promover ações educativas, fundamentadas no respeito à diversidade cultural e na participação comunitária, contribuindo para ampliar o acesso da sociedade às manifestações culturais e ao patrimônio material e imaterial da Nação".

Segundo o Caderno de Diretrizes Museológicas (MINC, 2006), ação educativa constitui uma série de procedimentos que promovem a educação no museu, tendo o acervo como o centro de suas atividades. Pode estar voltada para a transmissão de conhecimento dogmático, resultando em doutrinação e domesticação, ou para a participação, reflexão crítica e transformação da realidade social. Neste caso, deve ser entendida como uma ação cultural, que consiste no processo de mediação, permitindo ao homem apreender, em um sentido amplo, o bem cultural, com vistas ao desenvolvimento de uma consciência crítica e abrangente da realidade que o cerca. Seus resultados devem assegurar a ampliação das possibilidades de expressão dos indivíduos e grupos nas diferentes esferas da vida social. Concebida dessa maneira, a ação educativa nos museus promove sempre benefício para a sociedade, configurando-se, em última instância, o papel social dos museus.

Nascimento (2005) também contribui para o debate sobre as práticas educativas em museus, afirmando que o

trabalho de construção de uma prática educativa em um museu envolve o universo cultural. Falar em cultura é sempre um desafio teórico, pois ela se compõe de ideias, concepções, significados sempre re-elaborados, ao longo do tempo e do espaço. Os significados e concepções atribuídos pelos membros do grupo e por eles partilhados se expressam concretamente, seja através das práticas sociais, do discurso, da fala, das manifestações artísticas ou, ainda, da criação de objetos. (p. 231). 
No entanto, não basta democratizar o acesso e promover ações educativas, é preciso que o processo tenha qualidade para que haja uma sólida formação cultural. Ainda mais quando levamos em consideração o caso brasileiro, pois, segundo Ghanem (2008, p. 61), o nosso país é um exemplo, dentre os muitos países, nos quais a separação entre educação formal e não formal é estanque e nítida.

Trilla (2008) afirma que pode haver uma relação de reforço e colaboração entre as esferas de educação formal e não formal, destacando que

recursos provindos de fora das instituições formais são frequentemente utilizados por elas no contexto de sua atividade: programas dos meios de comunicação; atividades que instituições como museus, bibliotecas, fundações culturais põem à disposição das escolas; fazendas, instalações agrícolas, viagens para educação ambiental; empresas que colaboram em programas de educação permanente etc. (p. 48).

Buscando compreender as pontes que podem se estabelecer entre a formação acadêmica e a formação cultural, no caso aqui estudado, através do Projeto Escola e Museu da Secretaria Municipal de Educação do Rio de Janeiro, no qual os alunos e seus professores percorrem sete museus e centros culturais, é necessário pensar no conceito de formação cultural e nos caminhos para se identificar se a mesma é ou não de qualidade.

Assim, para entender a noção de formação cultural e de qualidade da formação cultural, inspirada, principalmente, nos estudos de John Dewey (2010), Walter Benjamin (1984, 1994), Gadamer (2005), Kramer (1998, 2012), Carvalho (2012, 2016), Flickinger (2000, 2014), Hermann (2005, 2010) e Lopes (2003) apresento o conceito de experiência como uma possibilidade.

\subsection{Experiência e formação cultural de qualidade}

Com a crise do modelo metafísico de pensar, que separava a dimensão formal da sensível, abriu-se espaço para o entendimento de que não existe uma verdade absoluta e, assim, surgem possibilidades e perspectivas de um novo olhar do conceito de formação do indivíduo. Definitivamente, essa crise da modernidade atinge a educação, que se baseava no referencial de homem racional. Em seu lugar, passa a vigorar a ideia de que é possível conciliar as dimensões formal e sensível, por meio da experiência estética, na formação dos sujeitos: a Bildung. 
Segundo Britto (2011, p.1, grifos do autor), "Bild, em geral, significa contorno, imagem ou, mais precisamente, forma - e o prefixo - ung assinala o processo segundo o qual essa forma seria obtida, o que nos permitiria traduzi-la em português por formação". Vale lembrar que o conceito de Bildung tem por base a multiplicidade de experiências (incluindo a estética). Para Maillard (1998, p. 12), "a estética se relaciona com nossa capacidade de apreender a realidade pelos canais da sensibilidade e põe em movimento uma disposição lúdica para a atividade criadora."

Com o passar do tempo, a Bildung perde força à medida que seu conceito é atrelado à utilidade e funcionalismo/competências e habilidades. No entanto, justamente neste contexto, Gadamer ${ }^{35}$ busca a retomada do termo na sua dimensão histórica, em que o diálogo é o que existe de mais relevante. Nesse sentido, Lago (2014, p. 28) afirma que Gadamer "destaca a necessidade de manter-se aberto às diferenças e ao outro, como forma de distanciamento necessário para ver-se e ultrapassar a si próprio.” É a partir dessa compreensão que, se encontra o potencial formativo da experiência estética, pois abre o sujeito à escuta do outro e à percepção de que os outros também podem ter razão. A partir da alteridade, como afirma Touraine (2006, p. 171), "trata-se aqui, na verdade, não mais do direito de ser como os outros, mas de ser outro". Complementarmente, Kramer (1998, p. 15) aponta que o que realmente importa é que

crianças e adultos possam aprender cultura e a arte guardadas nos livros, com os textos, com a história, com a experiência acumulada. Ainda que ideologicamente marcados, tendo todos eles uma linguagem jamais isenta de preconceitos, a experiência com a produção cultural contribui de maneira básica na formação de crianças, jovens e adultos, pois resgata trajetórias e relatos, provoca a discussão de valores, crenças e a reflexão crítica da cultura que produzimos e que nos produz, suscita o repensar do sentido da vida, da sociedade contemporânea e, nela, do papel de cada um de nós.

De acordo com Hermann (2005), o termo estético é oriundo do grego aisthesis, aistheton e significa sensação, percepção através dos sentidos, sensibilidade. Segundo Medeiros (2005, p.13), resulta em "estar aberto ao mundo, aberto ao sensível do mundo/no mundo e deixar-se contaminar."

\footnotetext{
${ }^{35}$ Hans-Georg Gadamer foi um filósofo alemão considerado como um dos maiores expoentes da hermenêutica filosófica do século XX. Sua obra de maior impacto foi Verdade e Método, de 1960.
} 
A partir deste ponto da tese, o termo formação será articulado à dimensão menos trabalhada no âmbito educacional, que é a cultural, através da experiência estética, colocando em movimento o sentimento, a sensibilidade e as emoções, atuando na construção da cognição e da ética. Segundo Hermann (2010),

A dimensão ética na educação está apoiada exclusivamente nas éticas racionalizadas, aqueles estudos de filosofia prática que enfatizam a crença no racional para a constituição da moralidade. Schopenhauer, antes de Nietzsche, já havia denunciado a prioridade da razão, das justificações racionais do agir moral, numa defesa da vontade e da intuição. Esse pensamento abre caminho para a não separação radical entre os domínios da ética e da estética e aponta o equívoco de que o ser verdadeiro do homem está no conhecimento e na consciência, que nosso acesso ao mundo das escolhas éticas dispensaria a sensibilidade e a intuição. (p.15).

Numa visão clássica, o conhecimento proveniente da estética era algo ilusório, sendo a arte tratada como uma imitação empobrecida da natureza, trazendo impacto nas ações educativas à medida que a dimensão da formação estética era desqualificada em relação à racionalidade. Com a modernidade, ocorre o deslocamento do objeto para o sujeito, trazendo a ideia de que o belo é o que gera o sentimento de prazer, sendo o gosto relativo. Contudo, sem desejar cair num relativismo absoluto e visando superar a divisão entre o racional e a emoção, ou seja, evitando a fragmentação das dimensões humanas, Hermann (2014) ressalta que

a experiência estética possibilita ampliar a nossa compreensão sobre nós mesmos e sobre o outro, possibilitando aprimorar nossa capacidade de escolha; sobretudo revela as limitações de nossas expectativas culturais, abre o horizonte interpretativo para o diferente, o que nos coloca diante de outro modo de compreensão. Nisso revela o seu impulso ético e a sua força educadora. (p.10).

$\mathrm{Na}$ experiência estética encontramos um caminho para nos compreendermos, pois permite um encontro consigo mesmo, nos confrontando, revelando aspectos que estavam encobertas, possibilitando estranhamento a respeito de algo, construindo novos significados num caráter dialogal do sujeito com a obra de arte que o interpela. Flickinger (2000, p.33) afirma que

a obra de arte é um convite insistente a que nos deixamos sugar para dentro do espaço de um mundo novo, alheio. É o choque entre o nosso mundo da vida e a promessa desse novo mundo possível, o que nos leva à experiência de uma profunda irritação. Irritação que nos impele a um posicionamento também novo, a um modo de abrir-nos procurando lugar dentro do novo espaço. Isso se dá através da descoberta e do desmascaramento de nossos próprios hábitos, interesses, paixões, orientadores da postura anterior. 
Lago (2014), com base no pensamento gadameriano, destaca duas dimensões da experiência estética significativas à formação: “a experiência estética efetivada no encontro do homem com a obra de arte e a experiência estética efetivada no encontro entre os homens com diferentes modos de ser, dois momentos ontologicamente articulados".

Ainda sobre o potencial das ações educativas através da linguagem das artes, Gadamer (2005) defende que

A arte não se oferece livre e indeterminada à interpretação que vem de disposições de ânimo, mas nos interpela com significados bem determinados. E o que há de maravilhoso e misterioso na arte é que essa interpretação determinada não representa um grilhão para nosso ânimo, mas justamente abre o espaço de jogo da liberdade lúdica de nossa capacidade de conhecimento. (p. 94).

Benjamin (1984) sugere que a experiência de um ser humano não é igual à do outro, ela não é transmissível de sujeito para sujeito e nem pode ser imposta por alguém, ela é de natureza pessoal.

Para Ana Elisabete Lopes (2003), o prazer estético é uma busca incessante:

Esta dimensão estética está presente nos diferentes períodos da história e se expressa de diversas formas, seja no universo reconhecido e valorizado das produções artísticas e culturais, seja dentro das ações mais simples das experiências cotidianas. Na concretização do desejo de experienciar esteticamente o mundo, descobrimos as múltiplas possibilidades de sua realização nas diferentes formas de percepção e de linguagens. (p. 47).

A partir de Walter Benjamin, Carvalho (2005) trabalha o conceito de empobrecimento da experiência, resgatando a ideia de que o próprio homem não se reconhece mais como sujeito da história, imerso na cultura, criado por ela e construtor dela. Assim, a autora apresenta a discussão de que esse empobrecimento ocorre também no processo de formação docente, defendendo que

É preciso pensar alternativas para que futuros professores se percebam como sujeitos construtores de sua prática. A ausência ou a falta de continuidade de políticas de investimento cultural que permitam ao professor, em complementariedade à formação pedagógica, o acesso a bens culturais são dados construídos pelo exercício de uma prática de desvalorização e de descompromisso com uma política social consistente. (p.134). 
Assim como tal empobrecimento envolve a preocupação com a formação dos docentes, defendo ser preciso ter atenção para esse aspecto também no âmbito da formação dos alunos.

Igualmente dialogando com Benjamin, Bondía (2002) aponta alguns fatores que ajudam a entender porque vivenciamos tantas coisas, mas a experiência mesmo é cada vez mais rara e pobre: (i) o excesso de informação, pois ainda que tenhamos mais conhecimento sobre algo, isto pode não ter nos tocado e gerado modificações; (ii) o excesso de opinião, já que o sujeito muitas vezes pensa que a sua opinião é supostamente pessoal e própria, quando, na realidade, muitas vezes tais informações e opiniões são fabricadas; (iii) a falta de tempo, uma vez que tudo passa muito depressa e os estímulos são rapidamente substituídos, reduzindo as possibilidades para os estabelecimento de conexões significativas entre os acontecimentos; (iv) o excesso de trabalho por estarmos sempre em atividade, não podemos parar e, por não podermos parar, nada nos acontece que nos toque, sensibilize.

Ressaltando que o ritmo mais vagaroso e a paciência, característicos do trabalho manual, é o que molda a experiência, Benjamin (1994) afirma que, para que uma experiência aconteça, é preciso dar tempo ao tempo, é preciso sentir com calma, refletir sobre o acontecimento.

Tais elementos, destacados pelos autores supracitados, podem também ser pensados no contexto escolar e isto nos leva a refletir sobre a qualidade da formação dos nossos alunos e questionar o tipo de experiências que estão vivenciando. Para o filósofo e pedagogo norte-americano John Dewey (2010), na educação, nem todas as experiências são igualmente educativas.

Não é suficiente insistir na necessidade da experiência, nem mesmo de atividade em experiência. Tudo depende da qualidade da experiência que se tem. A qualidade de qualquer experiência tem dois aspectos: o aspecto imediato de ser agradável ou desagradável e o segundo aspecto diz respeito a sua influência sobre experiências posteriores. (p. 28, grifo meu).

Com a linguagem das artes, no contexto educacional, é possível encontrar um caminho para o desenvolvimento da aprendizagem através da experiência estética, visto que a mesma compreende uma pluralidade de experiências, resgatando a formação cultural, na tentativa de superar o empobrecimento discutido anteriormente, buscando a construção de um olhar mais sensível e 
inteligível sobre a realidade que nos cerca. Assim, a escola pode possibilitar a construção de um diálogo entre as experiências cotidianas dos alunos, os conteúdos escolares e as produções culturais pertencentes as mais diferentes épocas, gerando uma interação entre diferentes saberes e contextos (social e cultural).

Para Ana Elisabete Lopes (2003),

Este exercício do olhar, de ver o diferente, de desvelar significados e critérios exige um trabalho continuado de educação do olhar que articule percepção, imaginação, conhecimento, produção artística e, ao mesmo tempo, valorize e respeite a multiplicidade e diversidade de pontos de vista, dos modos de ver e estar no mundo. Percebemos a realidade de forma distinta porque somos diferentes. Nossas emoções e conhecimentos interferem nas formas de ver e acarretam diferentes olhares sobre a realidade. (p. 53).

Desta forma, pensar em formação cultural é refletir acerca da qualidade da experiência cultural que os alunos da rede municipal de educação do Rio de Janeiro estão vivenciando. Para Dewey (2010), a educação que está preocupada em criar experiências de qualidade deve levar em consideração os aspectos sociais dos alunos e os fatores externos a ele.

Nesse sentido, Kramer e Carvalho (2012) destacam que a experiência no interior dos museus afeta a fruição estética que acontece fora deles e afirmam que

o sentido da visão, contudo, pode ser aprendido de novo: a arte em geral e os museus em particular podem ensinar a olhar de outra maneira, contemplar de outro ângulo, não como mera reprise de algo visto e reiterado, mas para retirar da relação com os objetos e as pessoas, outros sentidos. Ou para atribuir outros sentidos aos objetos, às pessoas, às relações. Sensibilizar-se e construir outro olhar é parte de um processo humano e humanizador ímpar que constitui as relações afetivas entre as pessoas. (p. 26).

A experiência estética desafia as nossas convicções e questiona as certezas, trazendo novos elementos para a reflexão e, assim, a estética na educação cumpre um papel formativo do eu.

Na seção seguinte, apresento considerações sobre as políticas de formação cultural. Será que as experiências culturais propostas através das políticas de formação cultural estão sendo de qualidade a ponto de sensibilizar os alunos da rede municipal do Rio de Janeiro? 


\subsection{Os contextos de influência, produção e prática da política de formação cultural}

Ball e colaboradores (Bowe; Ball; Gold, 1992; Ball, 1994) elaboraram o conceito de ciclo de políticas levando em consideração que o mesmo apresentaria três contextos: o contexto de influência, o contexto da produção do texto da política e o contexto da prática.

De modo geral, os três diferentes contextos são usados como recurso analítico nos estudos de políticas públicas educacionais de cunho avaliativo e de responsabilização docente. No entanto, nessa etapa da tese, farei uso dessas três unidades de contexto como referencial analítico no âmbito das políticas de formação cultural, com o objetivo de examinar a trajetória do Projeto Escola e Museu desde a sua formulação até a sua implementação.

De acordo com Mainardes (2006, p. 51), no contexto de influência "os conceitos adquirem legitimidade e formam um discurso de base para a política", ou seja, é o momento em que as políticas públicas são principiadas e grupos de interesse podem disputar para influenciar o rumo das finalidades educacionais, podendo envolver acordos até mesmo com as agências multilaterais e, também, há uma tendência em se considerar ações de sucesso já executadas em outras localidades.

Em termos de políticas de formação cultural, também é possível verificar influências internacionais e nacionais nas políticas municipais, compondo um processo denominado por Ball $(1998$, p.132) de bricolagem de concepções teóricas, ou seja, uma atividade em que as ideias são ajustadas ao contexto local. Para entender tal processo, apresento a seguir uma abordagem histórica da política cultural nacional, que tem servido de base para o desenvolvimento da política municipal do Rio de Janeiro, por exemplo.

Como descrito anteriormente, a base legal das políticas públicas de cultura atuais brasileiras é oriunda dos artigos 215 e 216 da Constituição Federal. Retomando, em síntese, a ideia principal, o Estado garantirá a todos o pleno exercício dos direitos culturais e o acesso às fontes da cultura nacional, e apoiará e incentivará a valorização e a difusão das diferentes formas de manifestação cultural.

A Constituição Federal, através do artigo 216, define o conteúdo do patrimônio cultural brasileiro como os bens de natureza material e imaterial, 
tomados individualmente ou em conjunto, portadores de referência à identidade, à ação, à memória dos diferentes grupos formadores da sociedade brasileira.

Através da Emenda Constitucional $\mathrm{n}^{\circ}$ 48, de 10 de agosto de 2005, acrescentou-se o $\S 3^{\circ}$ ao artigo 215 , que instituiu a obrigatoriedade de implantação do Plano Nacional de Cultura, de duração plurianual, visando o desenvolvimento cultural do país e a integração das ações do Poder Público que conduzam à defesa e valorização do patrimônio cultural brasileiro; produção, promoção e difusão de bens culturais; formação de pessoal qualificado para a gestão da cultura em suas múltiplas dimensões; democratização do acesso aos bens de cultura; e valorização da diversidade étnica e regional.

Segundo Tolentino (2007), o plano plurianual configura-se um instrumento gerencial adotado pelo governo federal, que tem como finalidade articular planejamento e orçamento e deve ser integrado à lei de diretrizes orçamentárias e à lei orçamentária anual. A duração é de quatro anos, com início no segundo ano de cada governo e terminando no primeiro ano do governo subsequente.

Nesse mesmo sentido, foi criado, pelo então presidente do Brasil, o Instituto Brasileiro de Museus (IBRAM), em janeiro de 2009, através da Lei ${ }^{\circ}$ 11.906, vinculado ao Ministério da Cultura (MinC), órgão responsável pela Política Nacional de Museus (PNM), estabelecida em 2003, e pela melhoria dos serviços oferecidos pelas instituições museais.

Instituído pela Lei 12.343, de 2 de dezembro de 2010, o Plano Nacional de Cultura (PNC) tem por finalidade o planejamento e implementação de políticas públicas de longo prazo (até 2020) voltadas à proteção e promoção da diversidade cultural brasileira. Diversidade que se expressa em práticas, serviços e bens artísticos e culturais determinantes para o exercício da cidadania, a expressão simbólica e o desenvolvimento socioeconômico do País. Os objetivos do PNC são: fortalecimento institucional e definição de políticas públicas que assegurem o direito constitucional à cultura; proteção e promoção do patrimônio e da diversidade étnica, artística e cultural; ampliação do acesso à produção e fruição da cultura em todo o território; inserção da cultura em modelos sustentáveis de desenvolvimento socioeconômico e estabelecimento de um sistema público e participativo de gestão, acompanhamento e avaliação das políticas culturais. A Lei que criou o PNC prevê metas para a área da cultura a serem atingidas até 2020. 
As metas do Plano, em número de 53, foram estabelecidas por meio da ampla participação da sociedade e gestores públicos. Vale destacar que o sucesso do PNC só ocorrerá com o envolvimento de todos os entes federados, por meio do Sistema Nacional de Cultura ${ }^{36}$.

Nesse momento, já é possível notar que os municípios são responsáveis por viabilizar a concretização do PNC, logo, as ações tomadas pela gestão atual da prefeitura não são medidas isoladas. A meta 28 do PNC prevê um aumento de $60 \%$ no número de pessoas que frequentam museu, centro cultural, cinema, espetáculos de teatro, circo, dança e música.

Um dos caminhos possíveis para cumprir tal meta é o aumento das visitas escolares a esses espaços, que tem o potencial de mobilizar e despertar o interesse dos alunos e docentes, mas também atrair seus familiares a partir de experiências de qualidade relatadas. Tais medidas legais fazem-se necessárias porque

No Brasil, a cultura ainda não é um direito usufruído pela maioria da população. Nesse sentido, o aumento da frequência às práticas artísticas e culturais deve ser o reflexo de políticas que estimulem a fruição, a formação de público e que ampliem a oferta de bens culturais. (Metas do Plano Nacional de Cultura, 2011, p. 61).

Além de ainda não termos conseguido viabilizar a cultura como um direito usufruído pela maior parte dos brasileiros, Canclini (2000) adverte sobre a diminuição de frequência aos equipamentos culturais relacionados à oferta cultural clássica, explicitando que esta é uma consequência típica da complexificação da vida urbana, como a indisponibilidade de tempo, as dificuldades nos deslocamentos pela cidade e o medo proveniente da violência urbana.

O Governo Federal reconhece a relevância da aproximação entre cultura e educação como estratégia para o desenvolvimento cultural e qualificação da educação nacional, afirmando que cultura e arte constituem a base para a educação integral.

É mais fácil aprender quando as abordagens pedagógicas são criativas e têm relação com a realidade cultural das crianças e jovens. Com o Mais Cultura nas Escolas, o ensino de crianças, adolescentes e jovens vincula-se às experiências

\footnotetext{
${ }^{36}$ Disponível em: http://www.cultura.gov.br/plano-nacional-de-cultura-pnc-. Acesso em: 3 jan. 2015 .
} 
culturais e artísticas das comunidades em que vivem ${ }^{37}$. (Ministério da Cultura, 2015).

Através de pesquisas como a de Cazelli (2010) e Carvalho (2016), por exemplo, é possível verificar a proeminência da escola como promotora das visitas aos equipamentos culturais. O estudo de Cazelli (2010), citado anteriormente, aponta o quanto a rede municipal do Rio de Janeiro faz diferença na prática de visita a museus, tanto nas unidades escolares de nível socioeconômico baixo como nas de nível socioeconômico alto. Tal fato também é confirmado em outras pesquisas como a de Grinspum (2000), ao investigar a ida de crianças de três escolas ao visitarem o Museu Lasar Segall (SP). Ao entrevistar os pais dessas crianças, os mesmos afirmam que não se sentem responsáveis por levar seus filhos aos equipamentos culturais, transferindo tal responsabilidade pela formação cultural para o espaço escolar. Novamente, fica evidente o quanto a escola faz diferença na introdução dos alunos nos espaços não formais de educação e formação de público.

O Plano Nacional de Cultura (PNC) configura-se como instrumento fundamental do Sistema Nacional de Cultura e tem como finalidade o planejamento e a implantação de políticas públicas de médio e longo prazos, adotando políticas estruturantes de cultura que ultrapassam o período de mandato dos governantes.

A $1^{\circ}$ Conferência Nacional de Cultura ocorreu em 2005 e os municípios participantes assinaram um protocolo de intenções, afirmando o compromisso na criação de conselhos, fundos e planos municipais de cultura. Dentre o conjunto de municípios que firmaram esse acordo, somente três executaram: Recife, Campo Grande e Joinville.

Em 2012, ocorreu uma retomada desse processo, porém, com um diferencial: a disponibilização de assistência técnica ${ }^{38}$ aos estados e municípios

\footnotetext{
${ }^{37}$ Disponível em: http://www.cultura.gov.br/educacao-e-cultura. Acesso em: 3 jan. 2015.

${ }^{38}$ A assistência técnica para a elaboração dos planos foi desenvolvida em parceria com as Universidades Federais da Bahia e de Santa Catarina, sendo a UFBA responsável pela metodologia aplicada aos Planos Municipais de Cultura e a UFSC pelos Planos Estaduais de Cultura. Essas Universidades assumiram o compromisso de capacitar uma equipe de consultores para auxiliar os gestores públicos na confecção de seus respectivos planos. Cada equipe é constituída por: 1 (um) Coordenador Consultor e 1 (um) analista consultor, sendo uma equipe para o município e outra para o Estado. Atualmente, todos os Estados da Federação fazem parte desse projeto e 20 (vinte) municípios, dentre eles o Rio de Janeiro, recebem a capacitação da UFBA para
} 
para que executassem seus planos de modo alinhado às diretrizes do Plano Nacional. Até o momento, o Plano Municipal de Cultura do Rio de Janeiro não está disponível.

Anterior aos planos nacional e municipal de cultura, existe o Plano Municipal de Educação da Cidade do Rio de Janeiro, expressando objetivos e metas que buscam a qualidade do ensino, por meio da Lei 4.866 de 2 de julho de 2008, em resposta à Lei Federal sancionada em janeiro de 2001, que estabeleceu o Plano Nacional de Educação, determinando que o Distrito Federal, Estados e Municípios elaborassem, em consonância com o nacional, seus próprios planos.

Diferentemente do Plano Nacional de Educação, o Plano Municipal de Educação da Cidade do Rio de Janeiro afirma ter inovado ao inserir um item sobre o Núcleo Curricular Básico da Multieducação, investindo também na universalização do Ensino Fundamental e prezando pela qualidade, acesso e permanência dos alunos.

De acordo com o Plano Nacional de Educação, a determinação legal de implantar o Ensino Fundamental de nove anos tem duas intenções: "oferecer maiores oportunidades de aprendizagem no período da escolarização obrigatória e assegurar que, ingressando mais cedo no sistema de ensino, as crianças prossigam nos estudos, alcançando maior nível de escolaridade". Nesta perspectiva, além do oferecimento de vagas, a Secretaria Municipal de Educação do Rio de Janeiro desenvolve uma série de investimentos, a saber: formação em serviço dos profissionais de educação; fortalecimento do trabalho realizado no Ciclo de Formação para alunos no período de desenvolvimento de seis a oito anos; a regularização do fluxo escolar com projetos específicos para alunos nas Classes de Progressão; participação de alunos e professores em projetos culturais; participação dos alunos em Projeto de Unidades de Extensão, que visa ampliar o horário escolar com atividades de artes, esporte e oficinas de educação pelo trabalho; desenvolvimento de projetos na área de meio ambiente e saúde; ampliação das Salas de Leitura; ampliação dos Pólos de Informática Educativa, implantação dos Laboratórios de Informática; atualização do Núcleo Curricular Básico Multieducação; melhoria do espaço físico escolar através de Projetos de conservação e obras, além do gerenciamento de verbas descentralizadas para cada Unidade Escolar. (p. 44-45, grifos meus).

\section{Tal documento já apontava que}

o acesso ao conhecimento, à diversidade cultural e aos valores sociais contemporâneos, por meio da escolarização das crianças e jovens a partir de seis anos, qualifica, cotidianamente, essa população para o exercício da cidadania. A multiculturalidade que constitui a população da cidade do Rio de Janeiro é valorizada por ações educacionais integradas aos princípios básicos do

elaborarem seus planos. Disponível em: https://planomunicipaldeculturario.wordpress.com/oque/. Acesso em: 3 jan. 2015. 
desenvolvimento humano, no respeito à diversidade e na valorização cultural como constituintes do cidadão carioca. (PNE, 2008, p. 45).

Fica evidente que a preocupação com a formação cultural na cidade do Rio de Janeiro foi estabelecida primeiramente no âmbito legislativo educacional e, posteriormente, no âmbito da Secretaria Municipal de Cultura. Esse movimento será aprofundado na próxima seção.

\subsection{A questão da formação cultural na rede municipal do Rio de Janeiro}

A preocupação com os resultados das avaliações externas e com as políticas de responsabilização é muito recente, ainda que já estivessem presentes no Plano Municipal de Educação do Rio de Janeiro, desde 2008. Antes da gestão do prefeito que tomou posse em 2009, os documentos educacionais estavam mais voltados a outras questões como, por exemplo, o desenvolvimento integral do aluno tanto do ponto de vista intelectual como social e moral.

Sem pretender discutir as questões político-partidárias, ou avaliar efetivamente as ações da Secretaria de Educação em diferentes gestões, em 1992 assume o prefeito da cidade do Rio de Janeiro que permaneceu mais tempo no cargo, totalizando 12 anos de gestão. Uma de suas principais ações foi a descentralização administrativa, com a criação das subprefeituras e da Multirio ${ }^{39}$ Empresa Municipal de Multimeios ligada à Secretaria de Educação, responsável pela produção de publicações, Projetos de TV, CD-ROM, vídeos e sítios voltados prioritariamente para a Educação.

No ano de 1996, o então prefeito, juntamente com a secretária municipal de Educação, conduziu, para toda a Rede Municipal de Ensino da Cidade do Rio de Janeiro, o Núcleo Curricular Básico MULTIEDUCAÇÃO. Esse currículo, em conformidade com as Diretrizes Curriculares Nacionais, configurou-se como a base sobre a qual as escolas municipais criaram e arranjaram, naquele momento, seus projetos pedagógicos. Durante a elaboração do Currículo Multieducação houve um contínuo diálogo entre os docentes da rede, contando com o apoio das

\footnotetext{
39 A criação da Multirio se deu por Lei municipal em 18 de outubro de 1993. Para obter mais informações: http://www.multirio.rj.gov.br/index.php/multirio/a-multirio. Acesso em 21 jul. 2017.
} 
Coordenadorias Regionais de Educação (CREs) e dos membros do Departamento Geral de Educação, caracterizando um meio de produção coletiva. O material foi enviado às escolas para avaliação, totalizando 1734 relatórios com críticas e sugestões que foram sendo acrescentadas à versão original. A proposta, de modo geral, foi bem recebida pelos profissionais de educação da rede, pois foi constatada a presença de aspectos inovadores que atendiam às expectativas da comunidade escolar, bem como a aplicabilidade à realidade escolar, uma vez que englobava os diferentes universos presentes no interior da escola.

Dependendo das bases teóricas, a palavra currículo apresenta diferentes concepções, e essa discussão é trazida à tona no Multieducação. No documento, é possível verificar a afirmação de que a organização proposta leva em consideração que currículo "é como um roteiro através do qual os estudantes viajarão sob a liderança de um guia experiente que é ao mesmo tempo um companheiro". (Pines, 1975, p. 95 apud SME/RJ, 1996, p. 107).

Dessa forma, o Núcleo recomenda conteúdos básicos, ou seja, uma base comum de conhecimentos fundamentais para todos, mas sem deixar de lado as especificidades dos professores e de seus alunos, visando partir da cultura particular para a inserção na cultura mais ampla. Assim, nesse material, há uma visão do ponto de partida e do ponto de chegada: o exercício de uma educação que almeje formar uma cidadania plena, na qual os alunos saibam ler, escrever, calcular e entender seu papel na sociedade.

Com esse novo currículo, buscava-se atender aos direitos dos alunos a uma educação de qualidade, mas levando em consideração a multiplicidade de contextos em que estão as diferentes escolas da rede, abrindo espaço para adaptações na proposta. Além disso, há uma intensa valorização do sujeito como agente ativo e incentivo à abertura da escola, introduzindo conhecimentos que vão além dos muros, isto é,

cabe à escola, pois, integrar vida e escola, sistematizando os conhecimentos que estão no mundo, de maneira mais formal e agradável. Esta é a meta do currículo Multieducação: uma escola que permita a entrada do mundo em seu interior - uma escola do tamanho do mundo. (SME/RJ, 1996, p. 110).

O currículo Multieducação está estruturado em torno de quatro Núcleos Conceituais (Identidade, Tempo, Espaço e Transformação) que são chave de leitura na interpretação das diferentes disciplinas e de quatro Princípios 
Educativos (Meio Ambiente, Trabalho, Cultura e Linguagens), cuja intenção é de que

os alunos percebam-se como parte integrante do meio físico, econômico social, cultural; aprendam os modos de produção e as relações de trabalho estabelecidas entre os homens; entendam-se como integrante de uma cultura com suas próprias formas de agir e de se expressar, sem, contudo, perder de vista que o intercâmbio entre diferentes culturas produz transformações que afetam as diferentes expressões culturais dos Grupos Sociais. (Portal Multirio, 2011).

Havia, portanto, uma forte valorização do desenvolvimento humano e dos processos de ensino-aprendizagem como formas de apropriação cultural, já que a escola é uma instituição social e historicamente construída, com o objetivo de sistematizar, transmitir e construir conhecimentos. Também era muito evidente a percepção de que o desenvolvimento humano se realiza nos diferentes recintos, criados pelos seres humanos, para a convivência social, e isso inclui os espaços de educação não formal.

A discussão e reformulação da proposta curricular da rede municipal foram incitadas a partir do estabelecimento dos Parâmetros Curriculares Nacionais, em 1997, pelo MEC, os quais forneciam subsídios para uma base curricular nacional comum, abrindo espaço para que estados e municípios contextualizassem suas realidades em suas próprias propostas curriculares, sem perder de vista a ideia de que deve ser garantido a todos os alunos o acesso aos mesmos saberes.

Em vários documentos disponibilizados posteriormente aos professores como, por exemplo, Multieducação - Temas em debate: Relações de ensino (2007), há uma ênfase nos estudos sociológicos de Bourdieu ${ }^{40}$ acerca dos processos que legitimam e perpetuam as desigualdades, ressaltando que o sucesso (ou o fracasso) dos indivíduos na escola depende de seu "capital cultural" e "habitus" ". Além disso, esses documentos ressaltam que a instituição escolar pode, através de seu modo de funcionamento, ser um locus de transformação, minimizando o impacto das diferenças de origem na aprendizagem.

\footnotetext{
${ }^{40}$ Pierre Bourdieu foi um destacado sociólogo francês do século XX. Publicou trabalhos sobre educação, cultura, literatura, arte, mídia, linguística e política.

${ }^{41}$ No material citado, a explicação presente para capital cultural é a de um sistema de valores implícitos, transmitidos por diversas vias, que influencia nas atitudes perante à escola. O termo habitus foi definido como conjunto de disposições para as ações que vão sendo incorporadas ao longo da vida de forma inconsciente, princípios que geram e organizam práticas, modos de pensar e de sentir (SME/RJ, 2007, p. 22).
} 
O capítulo 8 do Multieducação - Núcleo Curricular Básico traz "Os artesãos da Esperança": Paulo Freire ${ }^{42}$ e Celèstin Freinet ${ }^{43}$. Em relação ao segundo autor, valoriza-se as aulas-passeio, destacando o encontro entre a escola e a vida; ou seja, a ruptura das fronteiras da sala de aula e o alcance da vida da comunidade. O capítulo 10 avulta que

a escola é a instância primordial que abre caminhos para que a cultura dos alunos tenha voz e vez. É o espaço privilegiado para que ela se manifeste. Ao mesmo tempo, porém, ela deve se preocupar com o universal, sob pena de segregar os seus alunos e, assim, impedir o seu acesso aos conhecimentos do mundo exterior e à sociedade mais ampla. O papel fundamental da escola será o de promover a democratização da cultura (acesso de todos à vida cultural organizada) e, ao mesmo tempo, estimular a democracia cultural (o livre exercício das diferenças). (SME/RJ, 1996, p.126).

Naquele momento, pelo menos no papel, foi possível perceber uma abertura para o diálogo com os espaços de educação não formal, abrindo novas possibilidades de aprendizagem e intercâmbio cultural. Ao longo dos Princípios Educativos e Núcleos Conceituais, desde a educação infantil até a antiga $8^{\mathrm{a}}$ série, esses espaços são frequentemente destacados como, por exemplo, na Proposta Curricular da $4^{\mathrm{a}}$ série, onde o reconhecimento do espaço cultural do Estado do Rio de Janeiro e suas relações nacionais e internacionais aparecem em evidência. Não estou, contudo, afirmando que a simples existência desses documentos configurava-se como garantia ou possibilitava a formação cultural dos alunos, mas sim que enfatizavam a sua relevância. É preciso pensar na formação cultural em diferentes dimensões: o padrão de acesso aos equipamentos culturais e a qualidade do que é ofertado aos alunos da rede municipal. Na pesquisa, aqui apresentada, priorizo investigar as duas dimensões: acadêmica e cultural.

Segundo Arroyo (2006), a escola precisa se preparar para bem socializar os conhecimentos escolares e facilitar o acesso dos alunos a outros saberes, já que os conhecimentos que se constroem e que circulam nos diferentes espaços sociais constituem direito de todos.

\footnotetext{
${ }^{42}$ Paulo Freire foi um educador, pedagogo e filósofo brasileiro. É considerado um dos pensadores mais notáveis na história da Pedagogia mundial, tendo influenciado o movimento chamado Pedagogia Crítica.

${ }^{43}$ Celèstin Freinet, educador francês que desejava criar um sistema democrático de educação, livre de contradições sociais. Ao propor a saída dos alunos da escola para uma aula-passeio, Freinet (1975) constatou o entusiasmo entre eles. Explorando os arredores, percebeu-se a curiosidade pelos acontecimentos extraclasse e a partir disso as aulas-passeio foram sendo incorporadas ao cotidiano da escola.
} 


\subsection{Cultura em Museu para quem?}

A partir da investigação "Ações Educativas em Museus e Centros Culturais-RJ" do Grupo de Pesquisas em Educação, Museu, Cultura e Infância (GEPEMCI), buscou-se identificar, além de outras questões, quais são as audiências contempladas por programações específicas. A pesquisa do GEPEMCI (2015) utilizou como instrumento de coleta de dados um questionário online enviado aos equipamentos culturais da cidade do Rio de Janeiro cadastradas no Guia de Museus Brasileiros - IBRAM (2011) e na publicação Museus RJ - Um guia de Memórias e Afetividades (2013). O questionário obteve o retorno de 85 dos 99 centros culturais e museus que estavam em funcionamento na cidade do Rio de Janeiro. O gráfico 4 retrata o percentual do público ligado ao contexto educacional formal que visitou os museus e centros culturais respondentes. Notase que os maiores percentuais são de estudantes do ensino fundamental, médio, superior e professores. Tais dados reforçam a ideia de que grande parte da audiência dos equipamentos culturais pesquisados é composta pelo público escolar.

Gráfico 4: Distribuição percentual do público escolar que visitou museus e centros culturais da cidade do Rio de Janeiro

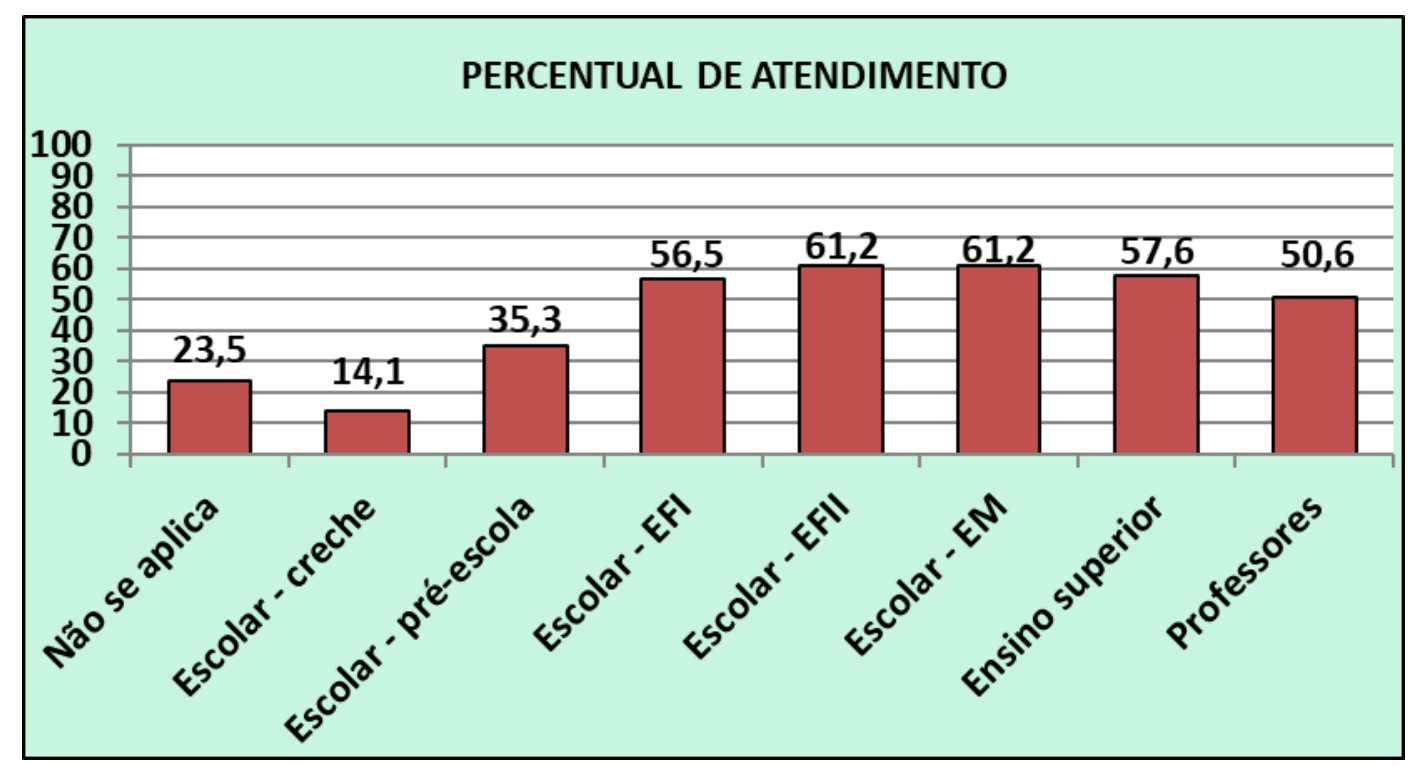

Fonte: Elaboração própria a partir dos dados do GEPEMCI (2015).

Com o objetivo de compreender como a população usufrui (ou não) da produção cultural da cidade do Rio de Janeiro, em 2015 foi desenvolvida uma 
pesquisa utilizando a metodologia de questionário, contendo 60 perguntas. $\mathrm{O}$ trabalho, que atingiu 1537 pessoas com 12 anos ou mais, foi uma iniciativa do poder público, gestores de espaços, pesquisadores, artistas e patrocinadores, e os resultados contribuiriam para mapear as dinâmicas de exclusão e fornecer dados para o poder público com relação às decisões de gestão e investimento. Os dados foram compilados e apresentados no Seminário Perfil Cultural do Carioca.

A amostra foi composta por $45 \%$ pessoas do sexo masculino e $55 \%$ do sexo feminino. Em relação à distribuição por faixa etária, 7\% com idade entre 12 a 15 anos, $16 \%$ entre 16 e 24 anos, $20 \%$ entre 25 e 34 anos, $16 \%$ de 35 a 44 anos, $22 \%$ tendo entre 45 e 59 anos e $19 \%$ possuindo mais de 60 anos. Quanto ao grau de escolaridade, $32 \%$ dos entrevistados tinha ensino fundamental, $43 \%$ apresentava ensino médio e $25 \%$ havia concluído o ensino superior. Sobre a classificação econômica, 7\% da amostra pertencia à classe A, 36\% era da classe B, $46 \%$ da classe $\mathrm{C}$ e $12 \%$ das classes D e E.

A cidade do Rio de Janeiro é a segunda cidade em número de museus, totalizando 124 museus, de acordo com dados levantados em 2010. Na pesquisa realizada em 2015, quando o recorte é feito olhando apenas para os museus, $25 \%$ dos entrevistados declararam que nunca visitaram esse espaço (gráfico 5).

Gráfico 5: Percentual de pessoas que nunca frequentou atividades culturais

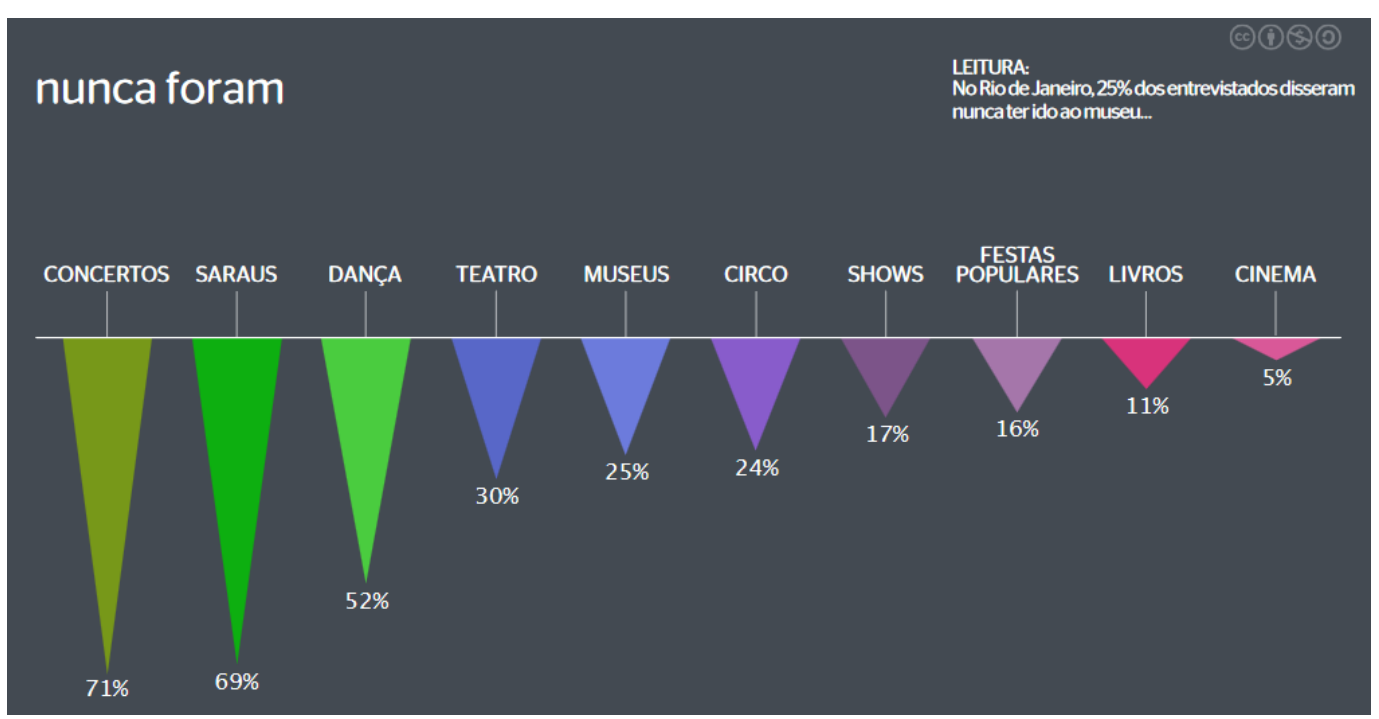

Fonte: Cultura no Rio/Divulgação ${ }^{44}$

\footnotetext{
${ }^{44}$ Disponível em: http://www.culturanorio.com.br/wp-content/uploads/2016/07/MESA_1. Acesso em: 2 mar. 2017.
} 
Levando-se em consideração o grau de escolaridade, a pesquisa revela que quanto maior a escolaridade (gráfico 6), menor é o percentual de pessoas que afirmam nunca ter praticado atividades culturais. Apenas $6 \%$ desses entrevistados nunca foram ao museu. Quanto menor a escolaridade, maior o percentual, maior a exclusão (gráfico 7). Dentre o grupo que tinha apenas ensino fundamental, $45 \%$ dos participantes da pesquisa nunca foram ao museu.

Gráfico 6: Relação entre o grau de escolaridade (com nível superior) e a não frequência às atividades culturais

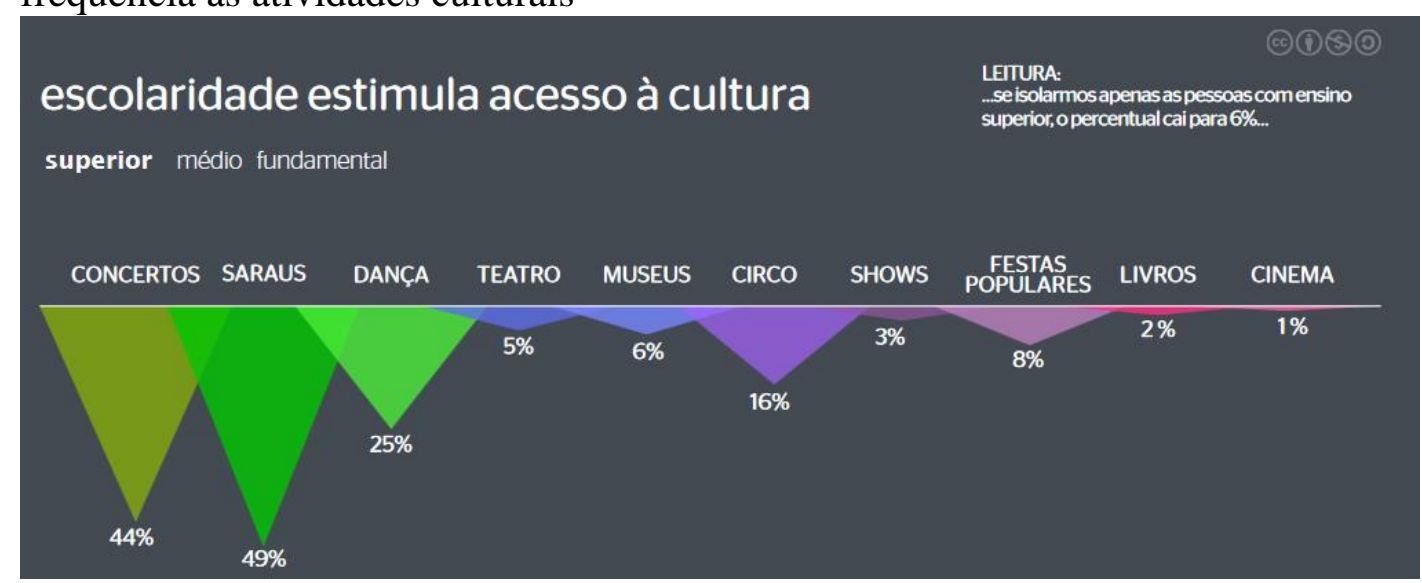

Fonte: Cultura no Rio/Divulgação ${ }^{45}$

Gráfico 7: Relação entre o grau de escolaridade (com nível fundamental) e a não frequência às atividades culturais

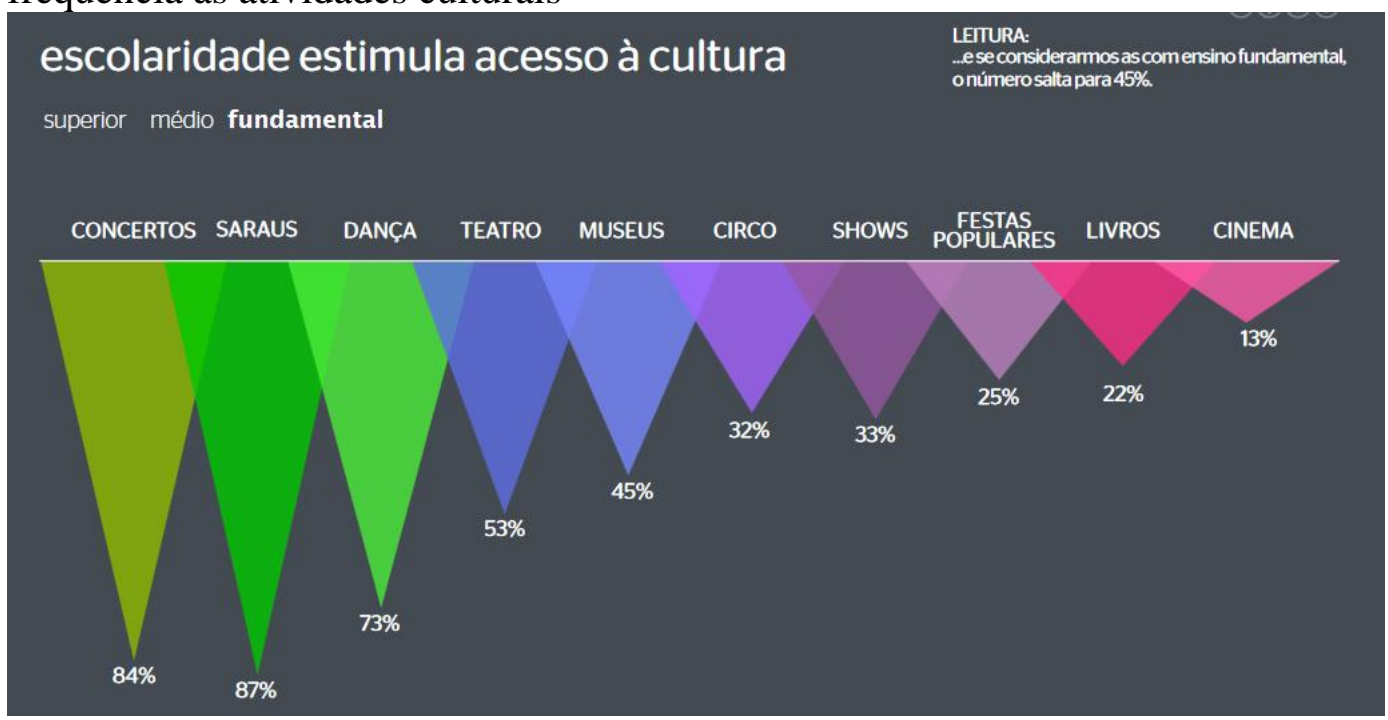

Fonte: Cultura no Rio/Divulgação ${ }^{46}$

\footnotetext{
${ }^{45}$ Disponível em: http://www.culturanorio.com.br/wp-content/uploads/2016/07/MESA_1. Acesso em: 2 mar. 2017.

${ }_{46}$ Disponível em: http://www.culturanorio.com.br/wp-content/uploads/2016/07/MESA_1. Acesso em: 2 mar. 2017.
} 
O mesmo comportamento ocorre quando o recorte tem por base a classificação econômica. As classes A e B apresentam percentuais menores de pessoas que nunca foram a determinadas atividades culturais como, por exemplo, museus e teatros, do que as classes D e E (gráfico 8). Quarenta e sete por cento das pessoas pertencentes às classes D e E nunca praticaram alguma atividade cultural.

Gráfico 8: Percentual de pessoas que nunca praticaram algumas atividades culturais pela renda

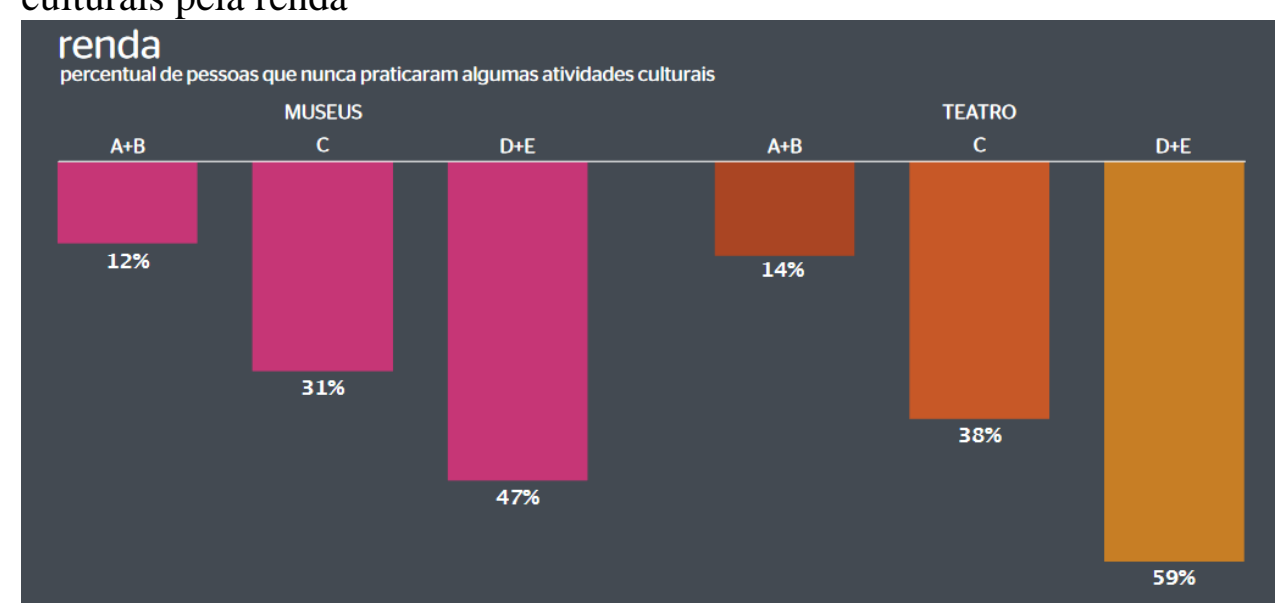

Fonte: Cultura no Rio/Divulgação ${ }^{47}$

Quando há separação pelo local de moradia e sua relação com a frequência aos museus, $47 \%$ dos moradores da zona sul foram aos museus nos últimos doze meses, totalizando $16 \%$ a mais de visitação em relação à média da cidade do Rio de Janeiro (gráfico 9). Porém, na zona oeste, apenas 28\% dos entrevistados moradores da região frequentaram museus ao longo de um ano, perfazendo um total inferior a 3\% quando comparado com a média de visitação da cidade. Os dados são ainda mais impactantes na zona norte, já que apenas $25 \%$ dos moradores conseguiram ir aos museus, ou seja, seis pontos percentuais abaixo da média.

Durante a realização da investigação, foi solicitado aos entrevistados que atribuíssem notas de 0 a 10 para seu interesse em museus. Os pesquisadores separaram então apenas os que não haviam feito essa atividade no último ano em dois grupos: os que deram notas entre 0-5 e os que atribuíram notas entre 6-10,

\footnotetext{
${ }^{47}$ Disponível em: http://www.culturanorio.com.br/wp-content/uploads/2016/07/MESA_. Acesso em: 2 mar. 2017.
} 
classificando o segundo grupo como o público em potencial. Foi possível constatar que $37 \%$ do público considerado potencial morava na zona norte do Rio de Janeiro e apenas $6 \%$ no centro carioca (gráfico 10).

Gráfico 9: Percentual de visitação aos museus nos últimos doze meses por região de moradia dos entrevistados

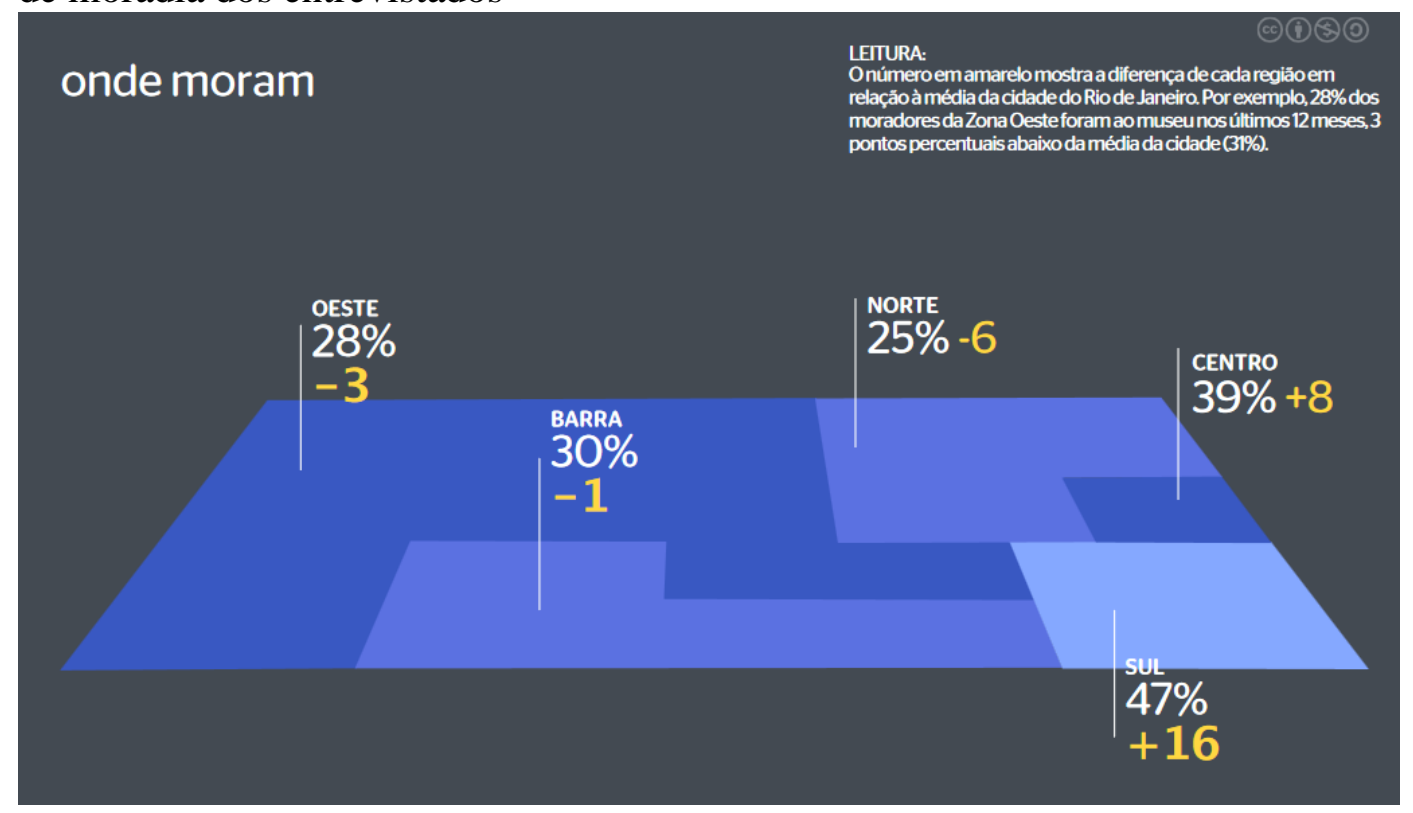

Fonte: Cultura no Rio/Divulgação ${ }^{48}$

Gráfico 10: Local de moradia do público potencial para os museus

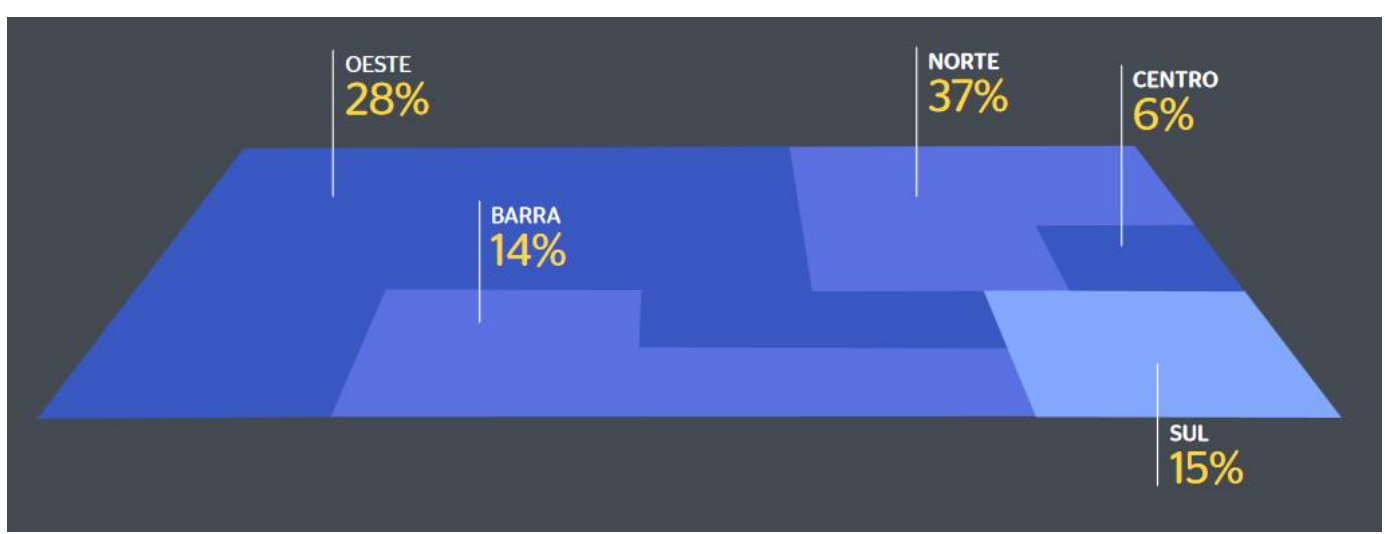

Fonte: Cultura no Rio/Divulgação ${ }^{49}$

${ }^{48}$ Disponível em: http://www.culturanorio.com.br/wp-content/uploads/2016/07/MESA_2. Acesso em 2 mar. 2017.

${ }_{49}$ Disponível em: http://www.culturanorio.com.br/wp-content/uploads/2016/07/MESA_2. Acesso em: 2 mar. 2017. 
Também foi investigada a razão de nunca ter ido ou ter ido há mais de um ano ao museu. Era uma pergunta aberta, podendo o entrevistado alegar até mesmo mais de uma razão. De modo geral, o desinteresse foi a resposta mais apontada, seguida por razões como: não gostar, falta de tempo, distância e dificuldade em chegar (figura 3).

Figura 3: Razões para não ir a museus

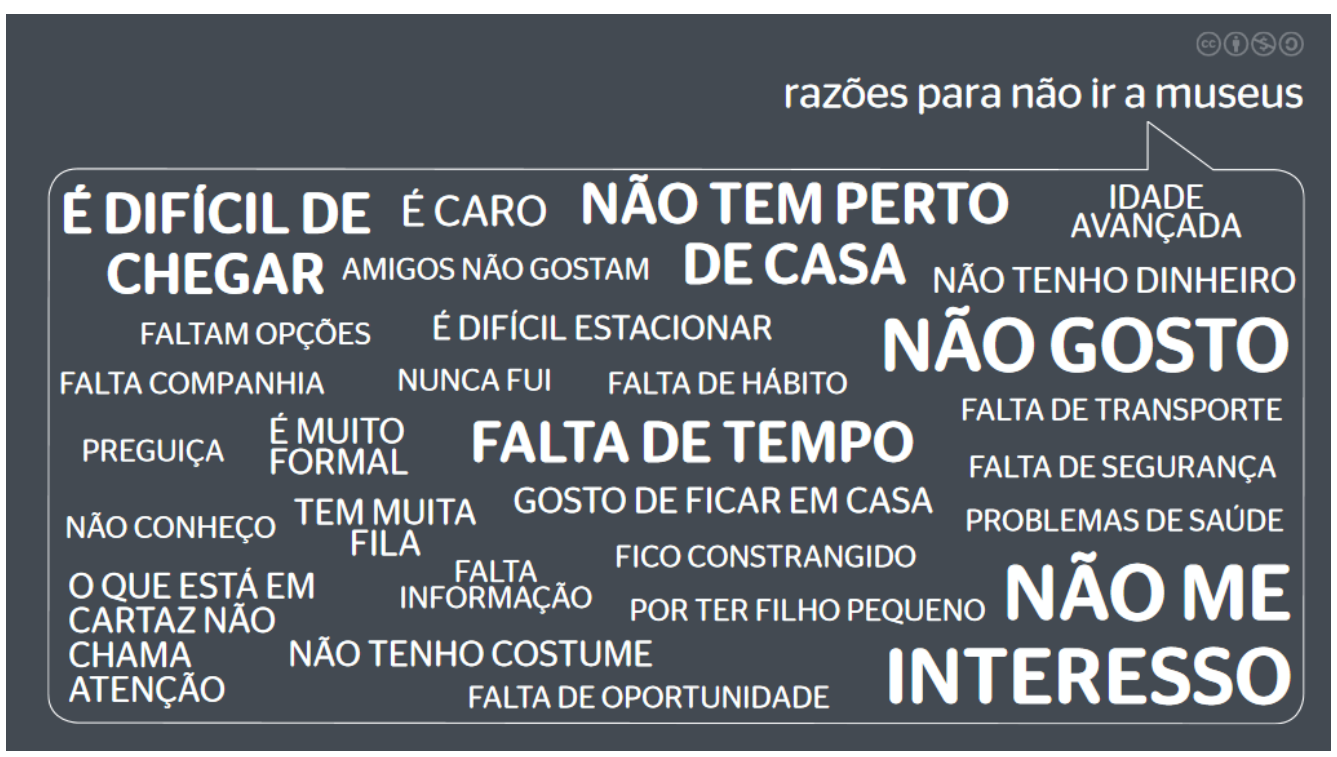

Fonte: Cultura no Rio/Divulgação ${ }^{50}$

As razões para não ir a museus são múltiplas e a falta de interesse já foi registrada em outras pesquisas. De acordo com o documento produzido pelo CPIM/DEPMUS/IBRAM (2012) ${ }^{51}$ acerca do "não público" dos museus,

A relação com espaços e práticas culturais é fruto de dinâmicas de socialização. Assim a disposição, por exemplo, para a prática cultural de ir a museus não constitui um ato natural. É o resultado de um processo dinâmico de constituição cultural. $\mathrm{O}$ estar na cidade e a proximidade de aparelhos culturais, como os museus, não promovem universalmente sua apropriação. Variáveis como nível de renda, escolarização, condições de moradia, gênero, capital cultural, situação geracional, entre outros, representam aspectos importantes para compreendermos as formas distintas de uso e apropriação dos espaços e práticas culturais. (p.3)

Mediante dados aqui apresentados, já é possível justificar um investimento da gestão anterior da prefeitura na construção de novos espaços ligados à cultura,

\footnotetext{
${ }^{50}$ Disponível em: http://www.culturanorio.com.br/wp-content/uploads/2016/07/MESA_2. Acesso em: 2 mar. 2017.

${ }^{51}$ Disponível em: http://www.museus.gov.br/wp-content/uploads/2013/09/naopublico.pdf. Acesso em: 26 jan. 2017.
} 
como o Museu de Arte do Rio (MAR), o Museu do Amanhã e o Oceanário AquaRio, que abriga o Museu do Surf, todos fazendo parte do projeto de Revitalização da Zona Portuária. Entretanto, essa iniciativa evidencia uma forte concentração no planejamento urbano nas áreas centrais da cidade, reforçando a desigualdade territorial dos equipamentos culturais, ainda que tenham sido inaugurados projetos em outras regiões como o Parque Madureira e as Naves do Conhecimento $^{52}$, que são polos de inclusão digital localizados nos seguintes bairros: Santa Cruz, Vila Aliança, Padre Miguel, Madureira, Irajá, Penha, Nova Brasília e em Triagem, mas que não são museus/centros culturais. Como visto anteriormente, as regiões com maior demanda de interesse por museus são a zona norte e a zona oeste.

Outra iniciativa, mais especificamente do âmbito da SME/RJ, voltada à questão cultural, foi a criação do Ginásio Experimental que tem arte em tempo integral. A Escola Municipal Vicente Licínio de Cardoso, localizada no bairro Saúde (Centro do Rio de Janeiro), começou o ano letivo de 2013 como Ginásio Experimental de Artes Visuais (GEA). A instituição foi selecionada por sua proximidade ao Museu de Arte do Rio (MAR) e, dessa forma, alunos e professores trabalham atividades integradas ao novo complexo cultural da Região Portuária.

Além das aulas regulares, são oferecidas aulas eletivas nos moldes de ateliês e os alunos do $7^{\circ}, 8^{\circ}$ e $9^{\circ}$ ano do ensino fundamental podem atuar juntos, de acordo com o que mais gostarem, em uma das nove opções: Artes Gráficas, 3D, Textura, Desenho, Cor, Pintura, Outras Mídias, Novas Tecnologias e Seres e Natureza. De acordo com a Secretaria Municipal de Educação, no GEA, além da interação com o Museu de Arte do Rio, os alunos têm, por semana, sete tempos dedicados às artes visuais.

Outro aspecto positivo é o fato de os alunos receberem reforço escolar nas matérias em que apresentam maior dificuldade e participarem dos programas Projeto de Vida e Protagonismo Juvenil. O primeiro desenvolve, junto aos alunos, atividades que abordam o tipo de ser humano que cada um quer ser, definindo o

\footnotetext{
${ }^{52}$ O projeto das Naves do Conhecimento é uma iniciativa da Secretaria Municipal de Ciência e Tecnologia do Rio de Janeiro (SECT), visando a democratização do acesso à informação e ao conhecimento de novas formas de aprendizagem em ambientes colaborativos e criativos promovendo a mediação da informação qualificada e o desenvolvimento de competências necessárias a todos na sociedade do terceiro milênio. Disponível em: http://navedoconhecimento.rio/. Acesso em: 18 jan. 2017.
} 
que esperam da escola e de suas vidas como um todo, e o segundo pretende que os alunos alcancem o conhecimento sobre si mesmo e sobre o ambiente.

A metodologia do Ginásio se dá a partir de professores polivalentes com dinâmicas pedagógicas interdisciplinares, sendo possível unir, por exemplo, História e Matemática. Todas as características dessa escola favorecem a formação cultural, mas também a dimensão acadêmica. Em todos os anos, a escola ultrapassou as metas estabelecidas pelo MEC para o Ideb, como pode ser observado no gráfico 11. É executado um trabalho diferenciado do restante do universo de escolas da rede e, pelo menos nas falas e nos índices, parece que está obtendo sucesso.

O grande objetivo disso é que, daqui por diante, a gente consiga formar cidadãos que se interem com o movimento artístico da cidade, percebam que o patrimônio artístico cultural do Rio é deles. Por isso também trabalhamos com o MAR. A gente trabalha em parceria e os nossos alunos frequentam o museu. Levamos para o trabalho educativo de lá e promovemos encontros artísticos. É muito bacana eles percebem que, se tiverem essa veia artística e vontade de usar isso na vida futura, esse é um caminho que podem percorrer. (Inês Resende - Coordenadora pedagógica da escola em entrevista para o Globo Educação ${ }^{53}$ ).

Levando-se em consideração o contexto de busca por alcançar metas escolares em avaliações externas, existe, principalmente no âmbito da SME/RJ, como já citado, um setor técnico-educativo responsável pela coordenação, promoção e acompanhamento pedagógico de Projetos e Programas Educacionais de Extensividade, visando colaborar com a melhoria do desempenho dos alunos, bem como para a sua permanência na escola.

Uma das iniciativas encontradas, desenvolvida pela E/SUBE/CED/ Extensividade junto às escolas da Rede Municipal, pelo terceiro ano consecutivo, é o Projeto Escola e Museu - Espaço Interativo de Educação e Arte em Novos Saberes, que tem como objetivo

ampliar e oferecer oportunidades educacionais para a aquisição de novos saberes, por meio da realização de atividades educacionais, aonde os alunos realizam um circuito em 07 Museus $^{54}$, acompanhados e estimulados por seus professores, que

\footnotetext{
53 Disponível em: http://redeglobo.globo.com/globoeducacao/noticia/2013/11/ginasioexperimental-de-artes-adota-pratica-pedagogica-interdisciplinar.html. Acesso em: 29 abr. 2017.

54 As instituições parceiras do Projeto (2015) foram: Fundação Eva Klabin, Centro Municipal Hélio Oiticica, Museu Nacional da UFRJ, Museu de Arte do Rio, Centro Cultural Banco do Brasil, Centro Cultural do Poder Judiciário do Estado do Rio de Janeiro e Oi Futuro. A cada ano, há mudança nas instituições parceiras.
} 
depois multiplicam essa experiência no interior da escola. Ressalta-se aqui a importância de se criar e ampliar a cultura de visita aos Museus da Cidade ${ }^{55}$.

Gráfico 11: Ideb segundo segmento do GEA

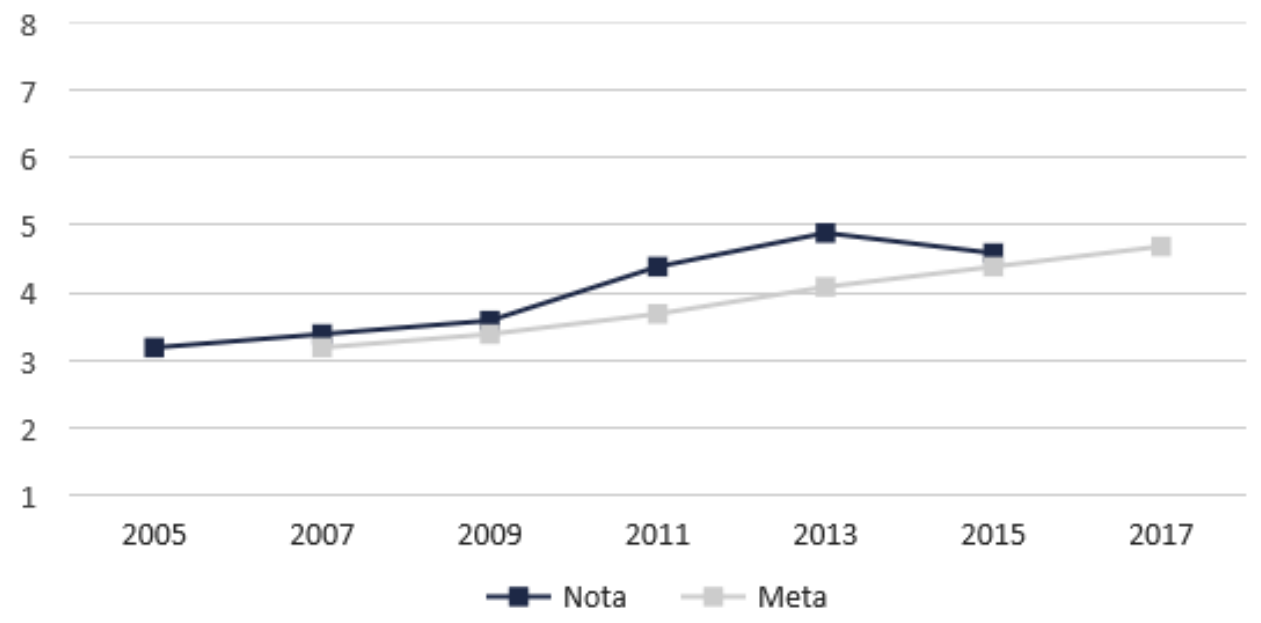

Fonte: Latitude - Educação Georreferenciada (2017).

No entanto, será que as ações desse Projeto da SME/RJ têm possibilitado uma abertura curricular das escolas para que tenham acesso aos equipamentos culturais no processo de formação cultural dos alunos, em conformidade com os dispositivos legais que preveem o acesso à cultura como base de uma educação integral? De que forma tais ações promovem equidade entre as escolas da rede municipal de educação a partir dos resultados obtidos nas avaliações externas?

$\mathrm{Na}$ tentativa de buscar algumas respostas, na seção seguinte, me dedicarei à análise do contexto da produção do texto e do contexto da prática da política educacional acerca da formação cultural da atual gestão, utilizando a abordagem do "ciclo de políticas" (policy cycle approach), e tomando por base os trabalhos de Stephen Ball e Richard Bowe.

55 Disponível em: http://extensividade-sme.blogspot.com.br/2013/08/formacao-de-professoresprojeto-escola.html. Acesso em: 27 fev. 2017. 


\subsection{O Projeto Escola e Museu}

Retomando o percurso metodológico, no capítulo anterior foi apresentada a fundamentação teórica sobre as duas dimensões acerca da qualidade educacional proposta nesta tese: a acadêmica e a cultural. Tendo em vista que um dos objetivos centrais da pesquisa é conhecer a qualidade da formação cultural dos alunos matriculados no segundo segmento das escolas da rede municipal do Rio de Janeiro em tempos de responsabilização docente, através do acesso desses adolescentes aos museus e centros culturais que atuam em parceria com a Secretaria Municipal de Educação do Rio de Janeiro (SME/RJ), passo a análise do Projeto Escola e Museu.

Tomei conhecimento sobre o setor de Extensividade da SME/RJ de forma tardia. Ingressei na rede municipal de educação em 2009 e, em nenhum momento, a estrutura organizacional foi apresentada. No entanto, quando assumi a segunda matrícula, em 2012, nessa mesma rede, inovações ocorreram e, durante o período de uma semana, junto a outros professores convocados à mesma época, vivenciei uma série de palestras ministradas no Centro de Referência da Educação Pública Anísio Teixeira $^{56}$. Tive a oportunidade de entender melhor o funcionamento da rede em que atuava há três anos. A cada início de ano letivo, os professores passam por uma Semana de Capacitação e, em 2014, em um dos encontros, pude assistir a apresentação ministrada pelo setor de Extensividade e, naquele momento, fui apresentada ao Projeto Escola e Museu ${ }^{57}$.

Tal Projeto, como outros da SME/RJ, não possui um texto oficial original disponível ao público $^{58}$, contendo uma síntese de suas concepções e

\footnotetext{
${ }^{56}$ A Escola de Formação do Professor Carioca - Paulo Freire (E/EPF), criada pelo decreto 35.602 de 09/05/2012, na gestão do prefeito que ocupou o cargo entre os anos de 2009 e 2016, é um espaço de produção de saberes e práticas pedagógicas para subsidiar o planejamento e a implementação da Política de Formação do Professor Carioca. A Escola é formada pela Gerência de Formação Básica, que promove ações de Formação Básica para professores ingressantes na Rede Pública Municipal de Ensino, pela Gerência de Formação Continuada, que promove ações para os professores em exercício, nas modalidades presencial, semipresencial e a distância e pelo Centro de Referência da Educação Pública da Cidade do Rio de Janeiro - Anísio Teixeira, que dispõe de importante acervo sobre a história da Educação Pública na Cidade do Rio de Janeiro possibilitando a produção de estudos e pesquisas que ampliam o processo de formação dos professores da Rede Pública Municipal de Ensino do Rio de Janeiro. Recebe, ainda, importante acervo bibliográfico que inaugura a Biblioteca Anísio Teixeira. Disponível em: http://epf.rioeduca.net/sobrenos.html. Acesso em: 21 de abril de 2017.

${ }^{57}$ Este não era o meu objeto de pesquisa inicial, mas, ao longo de 2015 , tentando delimitar melhor a pesquisa, visando desenvolver um estudo que contempla a formação acadêmica e a formação cultural, essa temática configurou-se como uma boa oportunidade.

${ }^{58}$ Várias tentativas foram feitas, sem sucesso, para ter acesso ao documento oficial do Projeto Escola e Museu. A justificativa para a não liberação foi a de que nenhum artigo acadêmico havia
} 
direcionamentos. Para analisar o contexto da produção do texto político, recorri aos textos "secundários", ou seja, materiais que falavam sobre o Projeto em sites da SME/RJ, facebook e blogs oficiais do setor de Extensividade e apresentações em PPT desse mesmo setor que me foram disponibilizadas por um integrante da equipe, com anuência da coordenadora.

Dedico-me agora a apresentar o Projeto Escola e Museu, bem como discutir as marcas do contexto de produção do texto. Os projetos desenvolvidos pela Extensividade são divididos em cinco áreas de conhecimento (esquema 1).

As principais ações da Extensividade são: i) contribuição para a formação da cidadania de alunos do Sistema Municipal de Ensino, por meio do desenvolvimento de atividades relacionadas às linguagens da arte, das atividades do esporte e da reflexão sobre temas do cotidiano; ii) promoção de atividades educacionais, no contra turno, colaborando com estratégias de diminuição da evasão escolar; iii) fortalecimento da autoestima do alunado, revelando valores, talentos e promovendo a construção de novos conhecimentos ${ }^{59}$.

O programa Escola e Museu tem por base os seguintes referenciais teóricos e regimentos legais: Gonhn, Maria da Gloria (Educação não formal e o educador social); Libaneo, José Carlos (Pedagogia e Pedagogos, para que?); Freire, Paulo (Pedagogia da Autonomia; Educação e mudança; Cultura popular, educação popular); Saviani, Demerval (Educação em Diálogo); MEC (Diretrizes Curriculares Nacionais); LDB 9394/96 e PCRJ- NCB Multiplicação.

Tais ações estão em conformidade, no contexto nacional, com a Resolução CEB $\mathrm{N}^{\mathrm{o}} 2$, de 7 de abril de $1998^{60}$, que institui as Diretrizes Curriculares Nacionais para o Ensino Fundamental. Em seu $3^{\circ}$ parágrafo determina que

São as seguintes as Diretrizes Curriculares Nacionais para o Ensino Fundamental: I - As escolas deverão estabelecer como norteadores de suas ações pedagógicas: a) os princípios éticos da autonomia, da responsabilidade, da solidariedade e do respeito ao bem comum; b) os princípios dos Direitos e Deveres da Cidadania, do exercício da criticidade e do respeito à ordem democrática; c) os princípios estéticos da sensibilidade, da criatividade e da diversidade de manifestações artísticas e culturais.

sido publicado no âmbito da SME discutindo os resultados do referido Projeto. Em nova tentativa, a coordenadora do Projeto Escola e Museu afirmou que o documento que possuem é uma normativa do projeto utilizada para desenhar todos os projetos institucionais e basicamente o que foi disponibilizado no PPT que usam para a apresentação aos gestores.

${ }^{59}$ Disponível em: http://extensividade.wix.com/sme-rj-extensividade\#!ações. Acesso em: 23 ago. 2015.

60 Disponível em: http://portal.mec.gov.br/cne/arquivos/pdf/rceb02_98.pdf. Acesso em: 23 agos. 2015 . 
II - Ao definir suas propostas pedagógicas, as escolas deverão explicitar o reconhecimento da identidade pessoal de alunos, professores e outros profissionais e a identidade de cada unidade escolar e de seus respectivos sistemas de ensino.

III - As escolas deverão reconhecer que as aprendizagens são constituídas pela interação dos processos de conhecimento com os de linguagem e os afetivos, em consequência das relações entre as distintas identidades dos vários participantes do contexto escolarizado; as diversas experiências de vida de alunos, professores e demais participantes do ambiente escolar, expressas através de múltiplas formas de diálogo, devem contribuir para a constituição de identidade afirmativas, persistentes e capazes de protagonizar ações autônomas e solidárias em relação a conhecimentos e valores indispensáveis à vida cidadã.

IV - Em todas as escolas deverá ser garantida a igualdade de acesso para alunos a uma base nacional comum, de maneira a legitimar a unidade e a qualidade da ação pedagógica na diversidade nacional. A base comum nacional e sua parte diversificada deverão integrar-se em torno do paradigma curricular, que vise a estabelecer a relação entre a educação fundamental e: a) a vida cidadã através da articulação entre vários dos seus aspectos como: 1. a saúde 2. a sexualidade 3. a vida familiar e social 4. o meio ambiente 5. o trabalho 6. a ciência e a tecnologia 7 . a cultura 8 . as linguagens. (p.1).

\section{Em entrevista ${ }^{61}$ com a coordenadora do Projeto Escola e Museu, realizada}

em 2016, ficou claro que se trata de um projeto cuja concepção surgiu a partir da ideia de integrar a escola a outros espaços de conhecimento que contribuam ampla e significativamente para a formação cidadã de cada aluno e professor envolvido na iniciativa.

Sou pedagoga e estou nessa Rede pública municipal de ensino há, pelo menos, 30 anos. Em minha opinião, a escola precisa, a todo o momento, se adaptar às mudanças sociais uma vez que ela lida com os diferentes atores sociais e sua relação entre si e a própria escola. É importante que ela propicie sentido aqueles que fazem parte do seu cotidiano e facilite aprendizagens. Ela lida com desafios o tempo todo mas precisa investir no diálogo com os seus alunos a fim de aproximálos de novos conhecimentos, acolhendo-os nos seus interesses, limites e desejos. O projeto vai ao encontro do ponto onde aluno e escola dialogam e dão sentido às novas aprendizagens e conhecimentos. Dessa forma diminui-se qualquer forma de distanciamento e ressignifica-se o aprendizado. A partir dessa ideia, pautei o desenho do projeto nas diretrizes Curriculares Nacionais, na forte parceria com as instituições de Arte, Cultura, Ciências etc, bem como, na possibilidade de garantir aos alunos e professores uma aproximação com a sua Cidade e com os bens que essas instituições promovem a partir de conhecimentos como: memória, patrimônio, diversidade cultural, arte e cultura, entre outros." (Trecho da entrevista com a coordenadora do Projeto Escola e Museu, 2016).

\footnotetext{
${ }^{61}$ Desde 2015, após a culminância do Programa Escola e Museu do referido ano, por diversas vezes foram feitas tentativas para uma entrevista com a coordenadora e gerente do setor de Extensividade. Ao final do segundo semestre de 2016, foram retomadas as tentativas e a coordenadora solicitou que as perguntas fossem enviadas por e-mail para que fossem respondidas. Portanto, a entrevista foi obtida por e-mail.
} 
Esquema 1: As cinco áreas de conhecimento do setor de Extensividade (SME/RJ)

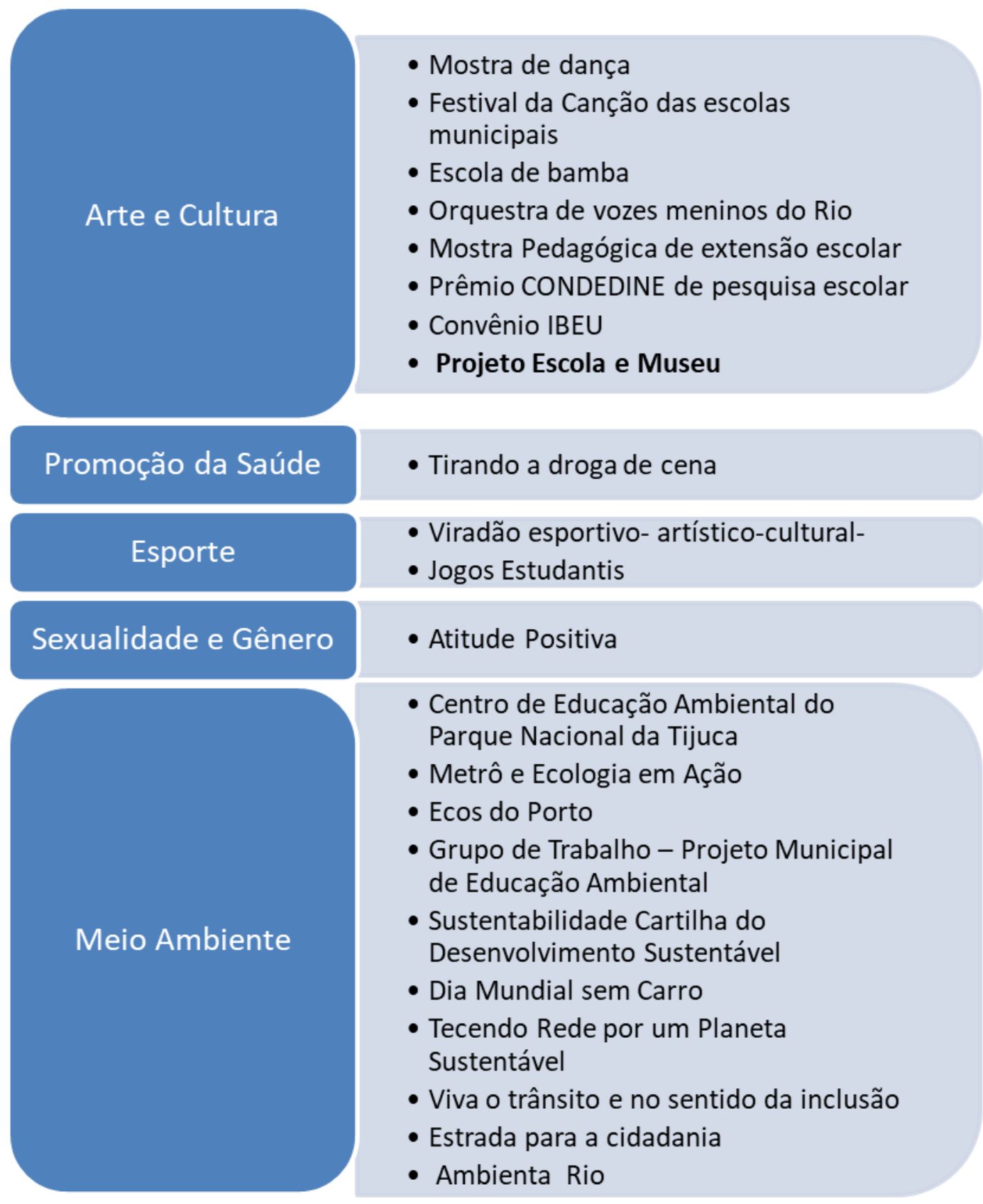

Fonte: Elaboração da autora a partir de informações obtidas em http://extensividade.wix.com/sme-rj-extensividade\#!projetos

Além disso, o Projeto Escola e Museu, de acordo com a fala da coordenadora, apresenta as seguintes vertentes que situam o que se quer com esse trabalho: i) promover o acesso de professores e alunos a museus, centros culturais, institutos de arte e cultura e a parques, como atividade articulada ao desenvolvimento do Currículo; ii) valorizar o patrimônio cultural da cidade; iii) 
formar público de visitação a instituições e espaços culturais, decorrente do desenvolvimento do interesse de alunos e professores pela apropriação de bens culturais; iv) aprofundar a aprendizagem dos alunos pela compreensão de conteúdos de disciplinas das áreas científicas, de arte e de comunicação linguística, proporcionados nas visitas às instituições culturais.

Quando questionada sobre a origem do Projeto e sobre a questão orçamentária, a coordenadora explicou que

A iniciativa foi concebida na SME e teve forte e intensa adesão dos museus. A SME disponibiliza ônibus e lanche para os alunos e os museus fazem o acolhimento e o trabalho de mediação com o espaço, ou seja, cada instituição assume o ônus que compete a si. A Prefeitura do Rio tem dotação orçamentária para atividades dessa natureza desde que incluídas no planejamento orçamentário. Há descentralização desse recurso e cada Coordenadoria de Educação disponibiliza os ônibus para as escolas da sua área de abrangência. (Trecho da entrevista com a coordenadora do Projeto Escola e Museu, 2016).

A oferta do transporte é um item que faz toda a diferença para aumentar o número de visitas aos museus. Pesquisas como a de Köptcke e Pereira (2010) mostram que o aumento significativo da visitação aos equipamentos culturais pode ser atribuído, quase sempre, a fatos extraordinários como a realização de grandes exposições. Porém, a diminuição de visitas é associada às condições do transporte urbano, que dificultaria o acesso aos museus (Oliveira, 2002-2003).

$\mathrm{Na}$ pesquisa institucional do GEPEMCI (2015), questionou-se sobre a oferta de transporte pelos equipamentos culturais para o público visitante. Como pode ser observado no gráfico 12 , apenas $9,4 \%$ dos respondentes apresenta uma resposta positiva. A oferta de transporte pelas CREs no Projeto Escola e Museu é um fator determinante na possibilidade de acesso aos equipamentos culturais parceiros da SME/RJ.

Gráfico 12: Disponibilidade de transporte para o público visitante.
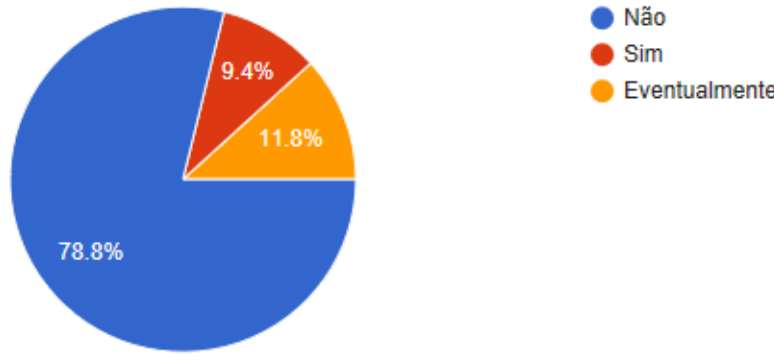

Fonte: GEPEMCI (2015). 
O Projeto Escola e Museu existe há quatro anos (2013-2016), tendo, a cada ano, um grupo de escolas diferente ${ }^{62}$. No primeiro ano, o foco foi os Ginásios Experimentais Cariocas (GECs), posteriormente, um grupo denominado Fênix (escolas com baixo desempenho nas avaliações externas), em 2015, ano em que se deu a investigação aqui apresentada, 22 Escolas do Amanhã foram contempladas e, em 2016, o projeto foi direcionado aos novos Ginásios Cariocas (nove).

O Projeto Escolas do Amanhã, que contempla as unidades escolares acompanhadas na pesquisa aqui relatada, foi criado em 2009 pela Secretaria Municipal de Educação do Rio de Janeiro e apresenta como objetivos reduzir a evasão escolar e melhorar a aprendizagem em 155 escolas do ensino fundamental localizadas em regiões conflagradas da cidade. Os principais pilares são ${ }^{63,64}$ :

1) Educação Integral - promover mais de 50 atividades de reforço escolar, cultura, artes e esportes e oferecer um ambiente estimulador e seguro para aprendizagem, promovendo uma permanência interessada do aluno na escola;

2) Bairro Educador - estimular um novo modelo de gestão de parcerias, visando transformar a comunidade em extensão do espaço escolar, fortalecer o Projeto Político Pedagógico da escola e integrar o processo de ensino-aprendizagem à vida cotidiana. Em cada unidade escolar há um profissional preparado para desenvolver ações de integração entre a escola e seu bairro;

3) Capacitação - promover capacitações e formações para o desenvolvimento de competências e habilidades de Gestores, Coordenadores Pedagógicos, Professores e demais profissionais que atuam nas Escolas do Amanhã em temas como resolução de conflitos e gestão e dinâmica de sala de aula;

4) Saúde nas Escolas - Projeto de atenção integral, promoção, prevenção e assistência à saúde para jovens e crianças. Todas as Escolas do Amanhã possuem um Núcleo de Educação e Saúde (NES), com mobiliário próprio para desenvolver o atendimento e material educativo. As unidades escolares contam com técnicos de enfermagem e visitas regulares de equipes móveis multidisciplinares compostas por médico, enfermeiro, dentista e auxiliar de saúde bucal;

\footnotetext{
${ }^{62}$ Durante a pesquisa, soube que algumas escolas estavam participando do Projeto pela segunda vez pelo crivo utilizado pela SME (exemplo: a escola tinha baixo desempenho, mas também estava situada em área conflagrada).

${ }^{63}$ Disponível em: http://www.rioeduca.net/ProjetosAcoes.php?id=19. Acesso em: 28 ago. 2015.

${ }^{64}$ Cabe destacar que durante a minha trajetória na rede municipal de educação do Rio de Janeiro trabalhei em uma Escola do Amanhã e, de fato, presenciei a existência, na prática, desses pilares.
} 
5) Cientistas do Amanhã - desenvolver mentes investigativas através de uma nova metodologia do ensino de Ciências, com formação continuada para professores, instalação de um laboratório de ciências em cada sala de aula e entrega regular de materiais. Através da metodologia inovadora o aluno é motivado a desenvolver seu senso crítico, autoconfiança e raciocínio lógico;

6) Estagiários e Voluntários - apoiar a comunidade escolar nas aulas de reforço, alfabetização, atividades nos laboratórios de informática e salas de leitura, entre outros. Mães voluntárias atuam sensibilizando alunos e famílias sobre a importância da escola em suas vidas, e monitorando a frequência e o comportamento dos alunos e suas relações.

Nesse ponto já é possível perceber um avanço no que diz respeito ao uso do resultado das avaliações externas para a promoção da equidade, já que, especialmente em 2014 e 2015, o critério de seleção das escolas que participariam do circuito cultural do Projeto Escola e Museu tinha por base o fato de terem baixo desempenho e estarem localizadas em áreas conflagradas da cidade, configurando-se um bom uso das medidas de aprendizado para a tomada de decisões políticas. Essa iniciativa da SME/RJ é relevante, pois, como apontam Soares e Delgado (2016),

As medidas de aprendizado produzidas pelo Saeb têm mostrado que o direito à educação não está garantido para todos. Há muitos estudantes que, embora matriculados em uma escola de ensino fundamental, não aprendem o necessário para suas vidas e existem grandes diferenças de aprendizado entre grupos de alunos, definidos por critérios sociodemográficos, como gênero, cor-raça, nível socioeconômico (NSE) e região de residência. Ou seja, o ensino fundamental brasileiro tem grandes e profundos problemas de qualidade e de desigualdade.

O nível do aprendizado dos estudantes domina o debate sobre a qualidade da educação enquanto a desigualdade ou fica em segundo plano ou é completamente ignorada. Contribui para isso o fato de que, como há um indicador amplamente usado que informa adequadamente sobre o aprendizado - o Índice de Desenvolvimento da Educação Básica (Ideb) -, não há um indicador padrão para a desigualdade educacional. (p. 756-757).

O processo de escolha das escolas participantes do Projeto Escola e Museu é conduzido pela Secretária de Educação, junto à equipe de Extensividade, e as instituições parceiras (museus e centros culturais) são selecionadas com base em dois critérios: i) instituições que já buscavam construir laços com as escolas da rede municipal de educação; ii) apresentam setor educativo atuante e realizam mediação, buscando fortalecer o retorno do aluno com as famílias. O Museu de 
Arte do Rio (MAR), por exemplo, entrega um voucher aos alunos, garantindo a cortesia do acompanhante.

Além disso, a coordenadora responsável pelo Projeto Escola e Museu na Extensividade afirmou durante a entrevista que algumas instituições são convidadas a partir da modalidade de acervo e área de atuação. Ao longo dos anos, alguns equipamentos culturais se desligaram por dificuldades da própria instituição.

$\mathrm{Na}$ proposta do referido Projeto (figura 4), em janeiro/fevereiro de cada ano, a SME convida as instituições parceiras para uma reunião e organizam o que será desenvolvido. Posteriormente, convidam os diretores e coordenadores pedagógicos para uma apresentação do projeto, objetivando uma sensibilização e adesão ao mesmo, já que a participação não é obrigatória. Em seguida, os diretores indicam um(a) professor(a) que será responsável pelo projeto em sua escola. O setor de Extensividade realiza um levantamento online das áreas de interesse e estudo dos docentes participantes. A partir de tais informações, são elaboradas as estratégias de mediação para as visitas e formação dos professores e, assim, professores e a equipe técnico-pedagógica das escolas participantes passam por um período de formação e realizam visitas orientadas nos equipamentos culturais antes de realizar o circuito com os alunos do $8^{\circ}$ ano (público alvo).

Após as visitas com os alunos às sete instituições parceiras, os alunos participam de um concurso de produção textual e realizam ações de multiplicação nas escolas. Por fim, são feitos registros dos resultados das ações pedagógicas nas escolas, cada uma apresenta um banner no Seminário Conexões Escola e Museu e é realizada uma pesquisa de avaliação online para docentes e alunos participantes, que será ferramenta de replanejamento entre a SME e as instituições culturais parceiras.

O projeto ganha vigor institucional quando ele abre. A despeito da iniciativa se pautar na educação não formal, ela também subsidia a educação formal como estratégia para novos conhecimentos. A partir dessa ideia, as escolas são indicadas pela gestão institucional e técnica da Pasta onde também faço parte. Dessa forma, a cada ano do trabalho, um grupo de escolas é indicado para ser foco.

Em 2015 as Escolas do Amanhã foram as indicadas, visando estimular também a escrita. Ou seja, a partir da participação no circuito interativo, os alunos foram estimulados a escreverem sobre as suas percepções àquelas experiências e que significado essas vivências trouxeram para as suas vidas tanto no âmbito escolar como pessoal. Os 3 alunos que produziram as redações mais significativas receberam um tablet como reconhecimento do seu trabalho e os demais 
apresentaram os seus trabalhos no Seminário Conexões Escola e Museu. (Trecho da entrevista com a coordenadora do Projeto Escola e Museu, 2016).

Figura 4: Exemplo de planejamento anual do Projeto Escola e Museu

\begin{tabular}{|c|c|c|c|c|c|c|c|c|c|c|}
\hline Ações & Feveratiro & Margo & Abril & Maio & Junho & Julho & Agosto & Setembro & Outubro & Novembro \\
\hline $\begin{array}{l}\text { 1. Reunião com as } \\
\text { Instituições }\end{array}$ & 21 & 25 & & & & $X$ & & & & \\
\hline $\begin{array}{l}\text { 2. Divulgação do Projeto para } \\
\text { as E/SUBE/CRE e diretores } \\
\text { das unidades escolares do } \\
\text { projeto Fênix }\end{array}$ & & 19 & & & & & & & & \\
\hline $\begin{array}{l}\text { 3. Visitas dos GECs às } \\
\text { Instituições }\end{array}$ & & & & & & & $X$ & $X$ & & \\
\hline $\begin{array}{l}\text { 4. Lançamento do Concurso } \\
\text { de Redação }\end{array}$ & & & & & & & $X$ & & & \\
\hline $\begin{array}{l}\text { 5. Formação com } \\
\text { professores Proj. Fênix (2) e } \\
\text { GECS (1) }\end{array}$ & & $X$ & $X$ & & & $X$ & & & & \\
\hline 6. Circuito Interativo & & & $X$ & $X$ & $X$ & & & & & \\
\hline 7. Seminário & & & & & & & & & & 8 \\
\hline $\begin{array}{l}\text { 8. Período para envio das } \\
\text { redações para E/SUBE/CRE }\end{array}$ & & & & & & & & $X$ & & \\
\hline $\begin{array}{l}\text { 9. Reunião da Comissão } \\
\text { Julgadora }\end{array}$ & & & & & & & & & $X$ & \\
\hline $\begin{array}{l}\text { 10. Resultado do Concurso } \\
\text { de Redação }\end{array}$ & & & & & & & & & & $X$ \\
\hline
\end{tabular}

Fonte: PPT disponibilizado pela Extensividade sobre o Projeto Escola e Museu 2014.

Retomando a análise com base na abordagem do ciclo de políticas e seus diferentes contextos, no que diz respeito ao contexto da produção do texto político, Ball e Bowe (1992) afirmam que esse tem uma forte relação de interdependência com o contexto de influências, pois o texto está articulado com a linguagem do interesse público geral, mas também é resultado das disputas ideológicas.

Em relação ao estilo do texto político, Ball e Bowe (1992) apontam que existem dois tipos, mas que há a possibilidade de que ambos estejam presentes em uma mesma política educacional, ou seja, podemos encontrar trechos mais prescritivos (reardely), que limita o envolvimento do leitor e outros com orientação mais participativa (writerly ou escrevível), convidando o leitor a ser colaborador do texto, possibilitando a participação mais ativa na interpretação do texto. 
Deste modo, já é possível perceber os dois estilos de texto no Projeto Escola e Museu. Em alguns momentos ocorre um tom mais imperativo, característico de um texto readerly, como, por exemplo, a exigência de que os professores envolvidos façam a formação nos equipamentos culturais e a participação exclusiva de alunos do $8^{\mathrm{a}}$ ano do ensino fundamental. Por outro lado, fica evidente momentos de maior possibilidade de diálogo com os participantes do Projeto Museu e Escola, algo típico de um texto writerly, tais como o levantamento do interesse dos docentes e a produção livre de atividades escolares a partir das experiências nos equipamentos culturais, visando a multiplicação das vivências para os demais alunos das escolas.

Além disso, o contexto da produção do texto da política não é finalizado no momento da aprovação e divulgação do texto, já que o mesmo pode ser reformulado. Tal característica fica bem evidente quando, ao final do período de atividades do Projeto Escola e Museu, docentes e alunos são convidados a fazer uma avaliação ${ }^{65}$ do Projeto (figuras 5 e 6), cuja função é ajudar na reformulação do mesmo para o ano seguinte.

Figura 5: Avaliação do aluno

Projeto Escola e Museu RJ

28 de novembro de 2015 - (2)

Prezado(a) Aluno(a)

Você participou de um circuito interativo entre importantes Museus e

Centros Culturais da nossa Cidade. Sua percepção sobre esse trabalho é

de grande valia para o fortalecimento das ações do Projeto Escola e

Museu. Desta forma pedimos a sua opinião, respondendo as perguntas a

seguir.

Equipe de Extensividade

https://docs.google.com/.../1EL2HpYosjQIFTiB57HcSEPT.../viewform

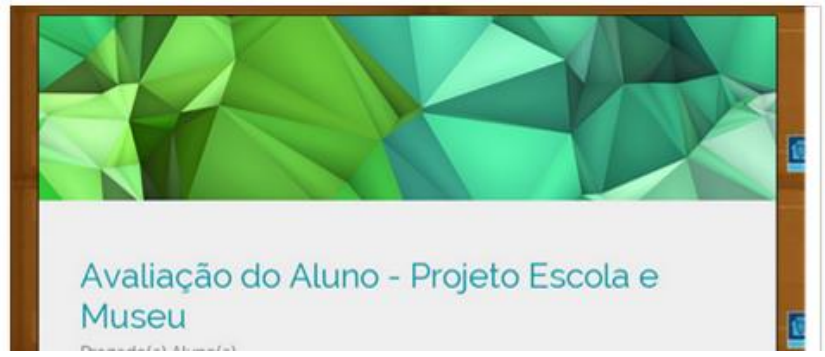

Fonte: Projeto Escola e Museu (2015) ${ }^{66}$

\footnotetext{
${ }^{65}$ Os resultados da avaliação realizada por alunos e professores serão apresentados e discutidos posteriormente.

${ }_{66}$ Disponível em: https://www.facebook.com/projetoescolaemuseurj/?fref $=\mathrm{ts}^{66}$.Acesso em: 5 jan.2016.
} 
Figura 6: Avaliação do professor

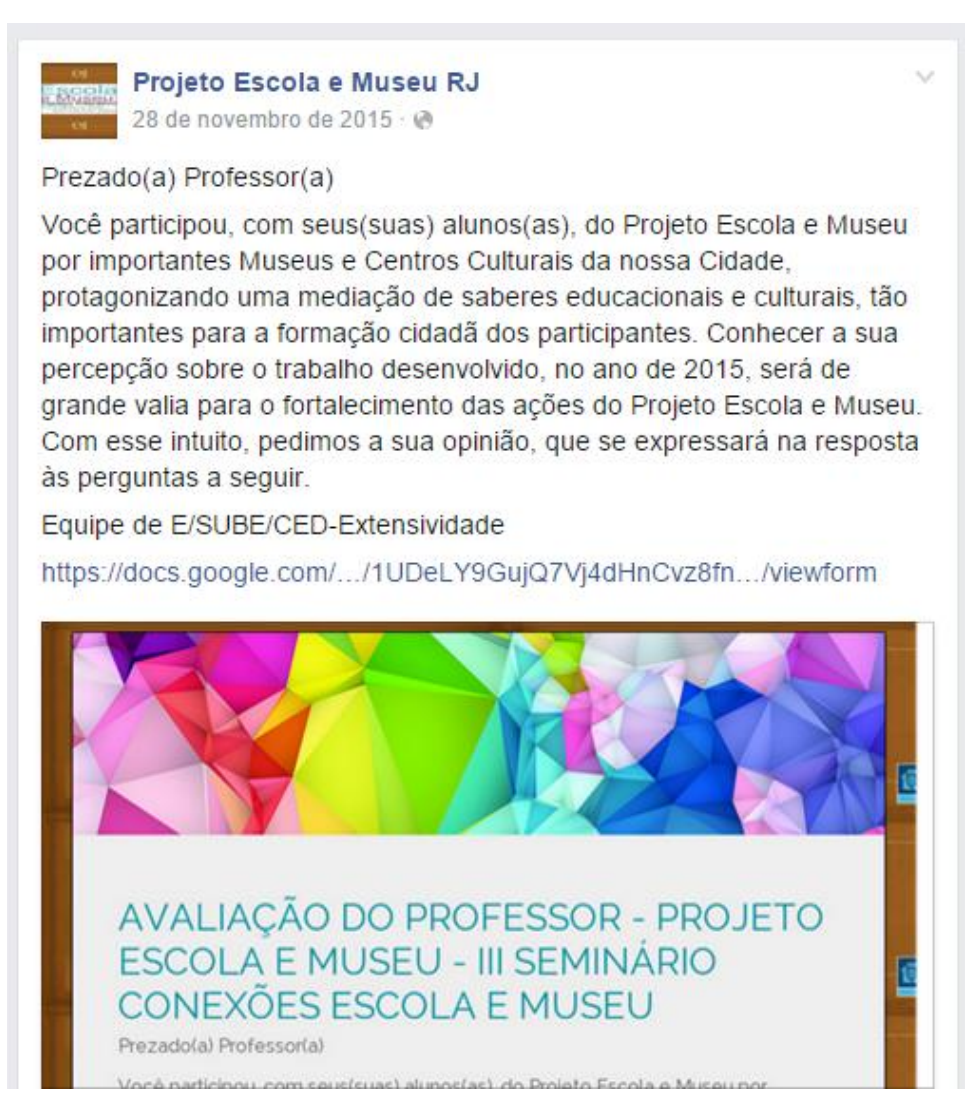

Fonte: Escola e Museu (2015) ${ }^{67}$

A coordenadora do Projeto Escola e Museu afirmou que não houve inspiração em nenhum outro Projeto já existente e que, em seu primeiro ano, foi uma iniciativa experimental que se consolidou posteriormente com as percepções elaboradas a partir daquelas experiências. Declarou também que a Rede Pública Municipal de educação é muito assediada, já que muitas instituições culturais buscam parcerias com a SME/RJ para a formação de público.

Apesar disso, cabe ressaltar que o desejo de construir parcerias com os alunos e docentes não é um movimento isolado, mas sim desenvolvido por outros museus e centros culturais que não são parceiros do Projeto Escola e Museu como, por exemplo, o Museu de Astronomia e Ciências Afins (MAST), em parceria com o Observatório Nacional, que desenvolve o Projeto "Olhai pro Céu Carioca", tendo como objetivo principal levar a astronomia às escolas da cidade do Rio de Janeiro. É uma iniciativa que também existe desde 2013, ofertando o empréstimo de telescópio às escolas e realizando cursos de capacitação para

\footnotetext{
${ }^{67}$ Disponível em: https://www.facebook.com/projetoescolaemuseurj/?fref=tsProjeto .Acesso em 5 jan. 2016.
} 
professores, oficinas e seminários para a discussão da ciência. Outra ação desenvolvida pelo MAST é "Planetário vai à escola", na qual um planetário inflável digital vai às escolas públicas e privadas do Estado do Rio de Janeiro.

Esse movimento de estabelecer relações entre escolas e museus já foi descrito por Pereira et al (2007):

Muitos museus atuam como instituições meramente complementares à sala de aula e são vistos dessa maneira por muitos educadores. Assim, as atividades do museu são utilizadas como enriquecimento às propostas desenvolvidas em classe, para comprovar e reforçar conteúdos abordados ou para ilustrar abordagens e enfoques escolhidos pelos professores. Embora seja uma forma legítima, ela, contudo, não é a única. Entendemos que os professores podem se preparar para desenvolvimento de ações educativas e para explorar, em parceria com a equipe educativa do museu, as atividades a serem desenvolvidas, a exploração do acervo e das exposições, bem como as diversas formas de uso do ambiente e das interações à disposição. Por outro lado, o museu precisa dialogar com os professores, no sentido de estabelecer terrenos comuns para a ação educativa, compartilhando, quando possível, a seleção de temáticas, propostas e roteiros educativos. (p.68)

Em sua pesquisa, Carvalho (2016) aponta que, em geral, as visitas aos equipamentos culturais são iniciativas individuais dos professores. Dificilmente configuram-se como projeto da escola. Nesse aspecto, portanto, o Projeto Escola e Museu é inovador e apresenta um avanço em relação às políticas de distribuição cultural porque não é apenas um projeto desenvolvido no interior de uma escola, mas sim uma política da Rede Municipal de Educação do Rio de Janeiro com o potencial de atingir escolas situadas em diferentes CREs a cada ano.

Dessa forma, o setor de Extensividade caracteriza-se como uma ponte entre a escola e o mundo que a cerca, ou seja, permite que a escola saia de si mesma e que os alunos e professores possam participar de outras experiências que poderão alterar de modo positivo a rotina da escola - antes, durante e depois. É um processo educativo que amplia a relação da escola com a sociedade. Dessa forma, o museu dispõe de condições eficazes para aprofundar esse trânsito que pode existir entre o "eu" e o "mundo fora de mim".

Pelo menos em tese, o Projeto apresenta aspectos positivos no sentido de possibilitar a ampliação da formação cultural dos alunos da rede municipal de educação carioca, buscando construir o hábito de frequentar o museu, tanto em alunos quanto em professores, de modo que os mesmos passam a fazer parte também do grupo denominado, no âmbito da museologia, de audiência espontânea e não apenas programada. De acordo com Coimbra et al (2012), 
esta é a audiência considerada como natural. É usualmente estudada mesmo que sua característica de participação espontânea não seja explicitamente mencionada. É a audiência com maior nível de autonomia sociocultural, visto que decide por ela mesma participar ou não do evento. Assim, pode-se dizer que a origem ou lócus do gerenciamento está na própria audiência, mesmo que nem todos os membros tenham poder e capacidade de empregar este gerenciamento. (p. 4)

Os mesmos autores também definem a audiência programada como

(...) um tipo de audiência considerado importante para museus. Compreende escolas (professores e estudantes) que agendam visitas, grupos turísticos que procuram visitas guiadas e os mais diversos grupos especiais que programam sua participação no evento junto à instituição organizadora. A audiência programada tipicamente possui um grau de autonomia sociocultural intermediário. O lócus de gerenciamento é compartilhado; parte pela própria audiência, ou por certos membros dela, e parte pela instituição envolvida. (COIMBRA et al, 2012, p. 5).

Outro aspecto importante dessa política é abordado em estudos como o de Cazelli e Coimbra (2013). Os autores afirmam que a literatura educacional destaca como notável a perda de motivação e de interesse ao longo dos primeiros anos de escolaridade, principalmente no ensino de ciência e de matemática. Nesse contexto, a educação não formal pode ser usada como contraponto à educação formal das escolas. Dando ênfase ao lúdico e ao prazer obtido na própria atividade, a educação não formal se apresenta de modo a contribuir no desenvolvimento da motivação intrínseca para o aprendizado das disciplinas.

Os museus e centros culturais não possuem compromisso com a certificação do saber e com a avaliação formal de conteúdos, assim, apresenta uma maior flexibilidade para desenvolver atividades e conquistar a motivação intrínseca do público. Pereira et al (2007) defendem que o museu é um ambiente educativo peculiar.

Ele tem um acervo de registros selecionados da vivência sócio-histórica. Ele tem, afinal, materialidade e oportunidades de simbolização não encontradas na escola. E é a partir de uma educação para olhar através dessa materialidade (dispersa, contraditória, lacunar e plural) que se realiza seu papel educador, sua peculiaridade e sua potencialidade. (p. 37).

Mais um ponto de destaque acerca da relevância do projeto idealizado pela prefeitura da cidade do Rio de Janeiro é que a ida aos espaços culturais pertencentes ao circuito não se dá buscando uma escolarização dos museus, ou seja, a proposta das visitas não pretende ilustrar os conteúdos programáticos das diferentes disciplinas escolares. Em algumas observações feitas das escolas durante o momento da visita e em conversas com os professores, o movimento 
percebido é de que alguns docentes desejam que o trabalho nos museus seja realizado levando-se em consideração os conteúdos escolares, enquanto outros professores revelaram que os alunos, a partir das descobertas e vivências nos espaços de educação não formal, estavam gerando novas demandas aos professores das escolas, desenvolvendo um percurso inverso, no sentido de levar um novo conhecimento ao espaço escolar, apresentado a partir das visitas, beneficiando inclusive os alunos que não participaram das visitas.

Assim como exposto por Pereira et al. (2007), quando tratam da formação profissional por meio das práticas educativas no museu,

A atividade desenvolvida permitiu aprendizagens multidirecionais, compartilhadas e a promoção da necessária transformação de rotinas profissionais. Nesse sentido, ela foi formadora para ambos os profissionais e também para os alunos. Mesmo estabelecendo uma relação a princípio tida como convencional - em que a escola vai ao museu meramente para receber informações ilustrativas de um conteúdo já desenvolvido em classe - o processo viria a transformá-la em oportunidade de formação e aprendizagens múltiplas. (p. 36).

O desejo por relacionar conteúdos escolares com as exposições presentes em museus e centros culturais já foi retratado por Kisiel (2005). Em sua pesquisa, o autor investigou os motivos pelos quais os professores levavam os alunos aos museus e os resultados encontrados revelaram que $90 \%$ dos docentes encontram na possibilidade de relacionar a visita aos conteúdos curriculares a principal motivação (tabela 8). No entanto, quando os mesmos docentes são questionados acerca dos fatores que são importantes para uma visita ser considerada bem sucedida, $61 \%$ afirmam que é quando os alunos se divertem e falam empolgados sobre a experiência no museu (tabela 9).

Tabela 8: Motivos para levar alunos a museus.

\begin{tabular}{lc}
\hline \multicolumn{1}{c}{ Motivos } & Percentual \\
\hline Possibilidade de relacionar a visita aos conteúdos curriculares & $90 \%$ \\
\hline Oportunizar aos alunos novas experiências & $39 \%$ \\
\hline Oportunizar experiências de aprendizagem & $30 \%$ \\
\hline Fomentar o interesse e a motivação & $18 \%$ \\
\hline Propiciar mudança de ambiente e de rotina & $17 \%$ \\
\hline Promover a aprendizagem ao longo da vida & $13 \%$ \\
\hline Proporcionar ao estudante uma experiência prazerosa & $11 \%$ \\
\hline
\end{tabular}




\begin{tabular}{ll}
\hline Satisfazer as expectativas da escola & $3 \%$ \\
\hline
\end{tabular}

Fonte: Com base em Kisiel (2005)

Tabela 9: O que é uma visita bem sucedida.

\begin{tabular}{lc}
\hline \multicolumn{1}{c}{ Considerações } & Percentual \\
\hline Se divertem e falam empolgados sobre a experiência no museu & $61 \%$ \\
\hline Adquirem novos conhecimentos & $41 \%$ \\
\hline Relacionam o que viram no museu com o que estão aprendendo & $23 \%$ \\
na escola & $17 \%$ \\
\hline Ficam motivados e interessados em aprender mais & $17 \%$ \\
\hline Se concentram e se comportam durante toda a visita & $8 \%$ \\
\hline Procuram discutir e questionar sobre os assuntos abordados & $5 \%$ \\
\hline Participam da visita conforme o previsto sem nenhum incidente & \\
\hline
\end{tabular}

Fonte: Com base em Kisiel (2005)

Retomando os aspectos positivos do Projeto Escola e Museu, outro benefício possibilitado é a formação docente em serviço. Carvalho (2016) relata que pesquisas desenvolvidas por profissionais de museus ressaltam o quanto a educação não formal está ausente dos currículos docentes de qualquer área. Desse modo, as visitas possibilitadas pela Extensividade da SME/RJ oportunizam aos professores uma inserção nesses espaços e o questionamento do que é realizado com os alunos, e até mesmo um repensar da prática docente a partir das experiências, despertando o desejo de buscar mais trocas entre a educação formal e os espaços culturais, proporcionando uma formação mais integral dos seus alunos.

No entanto, o Projeto Escola e Museu apresenta alguns fatores limitantes como, por exemplo, o atendimento restrito aos alunos do $8^{\circ}$ ano do ensino fundamental e o fato de que apenas algumas escolas são contempladas. Se tal iniciativa da SME apresenta o potencial de ampliar a formação cultural de alunos e professores, por que não ampliar para, pelo menos, uma série pertencente à educação infantil e uma ao primeiro segmento do ensino fundamental? Conforme destaca Carvalho (2014, p. 311),

as crianças pequenas merecem um atendimento e um reconhecimento de que são capazes de frequentar esses espaços, de que têm esse direito - como 
sujeitos e cidadãos -, de que têm especificidades que precisam ser respeitadas.

Outra questão é a localização de espaços museais e centros culturais nas imediações do Centro e da Zona Sul da cidade (tabela 10 e mapa 2), o que demanda oferta de transporte e, dependendo da localização da escola, é necessário "atravessar" a cidade e, por fim, não priorizar os próprios equipamentos culturais da Secretaria Municipal de Cultura. Não vejo como algo ruim ter que atravessar a cidade, já que propicia a descoberta e o conhecimento de outros bairros e equipamentos culturais. Porém, é preciso refletir sobre as condições desse deslocamento: a oferta de transporte, segurança, engarrafamento etc. Além disso, é importante despertar o olhar para os equipamentos museais presentes na circunvizinhança da escola, que serão de mais fácil acesso e apresentam potencial para um trabalho duradouro. Entretanto, tais questões não inviabilizam a importância dessa política, mas precisam ser levados em consideração nos momentos de reavaliação. Faz-se necessário também pensar por qual razão as escolas localizadas no Centro e na Zona Sul não poderiam igualmente se deslocar para equipamentos culturais localizados em outras regiões. Seria um ganho territorial para esses alunos também.

Tabela 10: Distância percorrida $(\mathrm{km})$ pelas escolas para chegarem aos equipamentos culturais do Projeto Escola e Museu (2015)

\begin{tabular}{l|c|c|c|c|c|c|c}
\hline Escola & CCBB & CCPJ & $\begin{array}{c}\text { Museu } \\
\text { Nacional } \\
\text { UFRJ }\end{array}$ & $\begin{array}{c}\text { Fundação } \\
\text { Eva } \\
\text { Klabin }\end{array}$ & $\begin{array}{c}\text { centro } \\
\text { Municipal de } \\
\text { Arte Hélio } \\
\text { Oiticica }\end{array}$ & MAR & $\begin{array}{c}\text { Espaço } \\
\text { Oi } \\
\text { Futuro }\end{array}$ \\
\hline Escola 1 & 11,7 & 13,5 & 7,7 & 17,4 & 10,4 & 10,6 & 13,6 \\
\hline Escola 2 & 4,1 & 5,9 & 5,6 & 10,6 & 3,4 & 4,6 & 5 \\
\hline Escola 3 & 16,9 & 17,6 & 15,4 & 6,6 & 17,3 & 17,8 & 12 \\
\hline Escola 4 & 10,9 & 16,5 & 6,6 & 18,5 & 9,6 & 11,2 & 12,9 \\
\hline Escola 5 & 13,6 & 16 & 8,8 & 18,8 & 12,1 & 13,7 & 15,4 \\
\hline Escola 6 & 11,4 & 14,4 & 6,3 & 16,8 & 10,1 & 11,6 & 14,6 \\
\hline Escola 7 & 19 & 19,5 & 13,8 & 24,4 & 16,4 & 16,6 & 21,2 \\
\hline Escola 8 & 13,3 & 15 & 8,7 & 18,3 & 11,9 & 12,1 & 15,1 \\
\hline Escola 9 & 24,6 & 25,2 & 19,5 & 30,1 & 23,6 & 23,8 & 26,8 \\
\hline Escola 10 & 20,6 & 21,1 & 15,4 & 25 & 18 & 19,8 & 22,8 \\
\hline Escola 11 & 31,3 & 31,8 & 26,1 & 35,7 & 28,7 & 28,6 & 31,9 \\
\hline Escola 12 & 27,3 & 27,9 & 22,2 & 31,8 & 24,8 & 24,7 & 27,9 \\
\hline Escola 13 & 34 & 34,4 & 21,6 & 23,9 & 24,6 & 31,8 & 27,9 \\
\hline Escola 14 & 30,9 & 31,5 & 21,3 & 27,8 & 24,2 & 26,9 & 27,5 \\
\hline Escola 15 & 31,3 & 31,8 & 24,9 & 28,2 & 25,8 & 28,7 & 29,1 \\
\hline Escola 16 & 28,8 & 31,8 & 23,7 & 27,3 & 23,2 & 26,3 & 27,4 \\
\hline Escola 17 & 47,5 & 48,1 & 42,3 & 53,7 & 45 & 44,9 & 48,1 \\
\hline
\end{tabular}




\begin{tabular}{l|c|c|c|c|c|c|c}
\hline Escola 18 & 48,9 & 42,4 & 43,7 & 47,3 & 46,2 & 46,2 & 44 \\
\hline Escola 19 & 42,6 & 43,1 & 37,4 & 46,7 & 40 & 39,9 & 43,2 \\
\hline Escola 20 & 66,3 & 66,9 & 58,1 & 58,1 & 63,8 & 64 & 63,6 \\
\hline Escola 21 & 66,9 & 67,4 & 61,8 & 73,1 & 64,3 & 63,5 & 67,5 \\
\hline Escola 22 & 68,5 & 69,1 & 63,4 & 58,8 & 66 & 65,1 & 69,1 \\
\hline Escola 23 & 67,6 & 68,1 & 62,5 & 73,8 & 65 & 64,2 & 68,2 \\
\hline
\end{tabular}

Legenda: $\square$ Menor distância

Fonte: Elaboração própria.

Mapa 2: Distribuição das escolas e dos equipamentos culturais pertencentes ao Projeto Escola e Museu (2015)

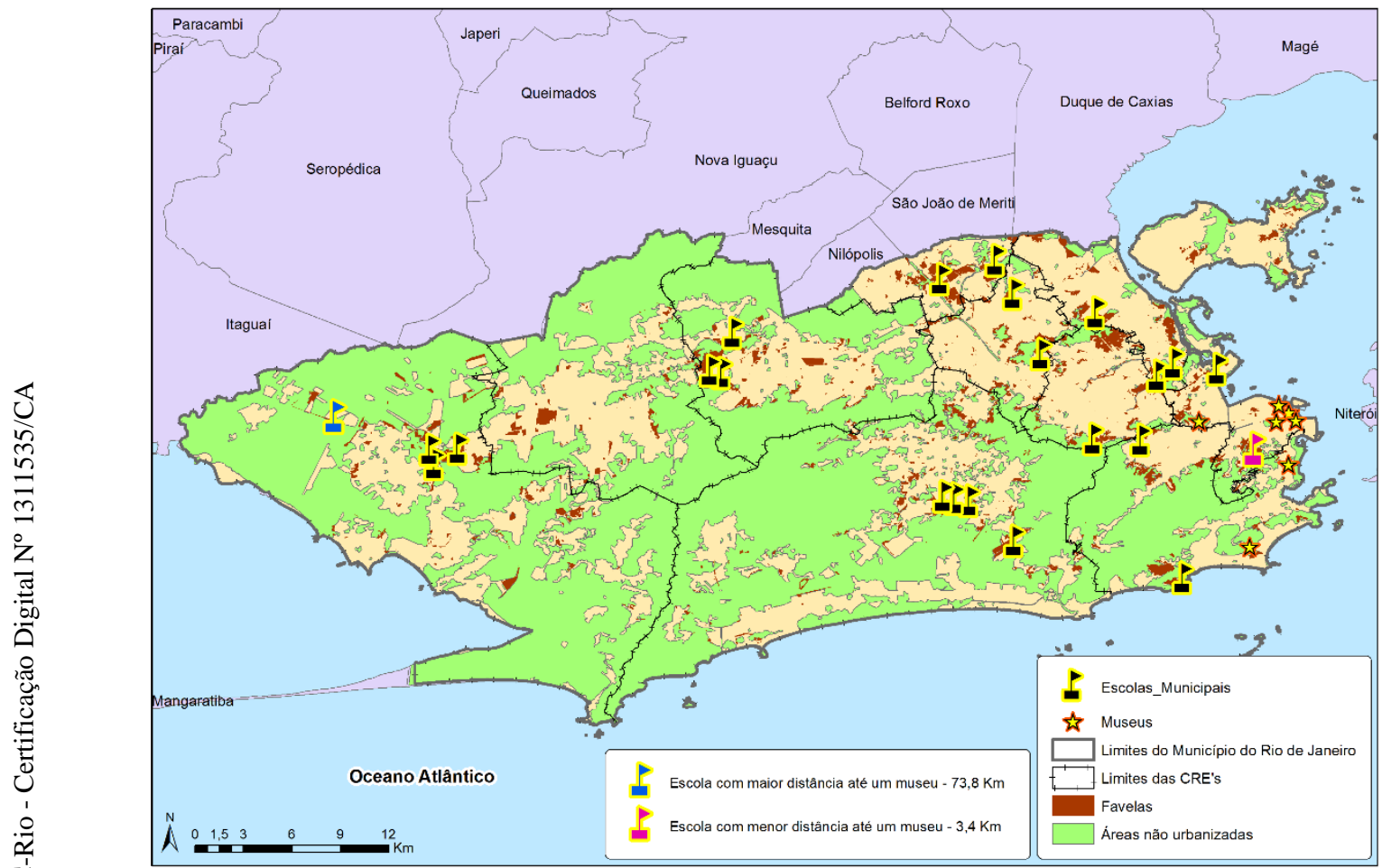

Fonte: Elaboração própria.

Por outro lado, não se pode deixar de fora a discussão sobre a qualidade da mediação que é realizada nos museus pertencentes ao circuito ofertado aos alunos e professores. É imprescindível ter a dimensão de que a mediação faz toda a diferença tanto para aproximar o público dos espaços não formais de educação quanto para afastá-lo, pois pode não despertar o sentimento de pertencimento aqueles espaços. Segundo Ribeiro e Frucchi (2007),

há que se reconhecer, entretanto, a essencialidade da presença do mediador, personagem cuja atuação no museu tem se mostrado fundamental na tradução das diferentes linguagens adotadas na aproximação público-exposição, públicoconteúdo, público-instituição museal. E o reconhecimento, a valorização do papel da mediação como a linguagem humana dos museus, revela a mudança de foco que 
vem ocorrendo, de modo especial nos museus de ciências: do conteúdo, do objeto, da técnica, para o homem, para o público, com sua sensibilidade, suas referências culturais, suas demandas de informação, de conhecimento científico e tecnológico, sua necessidade de sentir-se inserido/incluído nesse contexto. (p. 68).

Por fim, é importante questionar qual é o papel do mediador. Seria o de explicar a exposição ou provocar reflexões acerca da mesma? Nesse sentido, a ida dos alunos e professores aos espaços museais não pode ser trabalhada a partir da concepção de que são tábulas rasas prontas a serem preenchidas por conceitos culturais que desconhecem, arruinando a possibilidade de desenvolver uma boa ação interativa, já que a interatividade foi perdida desde o momento da concepção. Discorrendo especificamente sobre os centros de ciência, mas que se aplica a outras tipologias de museus, Costa (2007) destaca que,

definitivamente, os centros de ciências são locais de aprendizado e não de ensino. Os 'explicadores' não deveriam se ver como professores ou educadores, mas como alguém que ajuda alguém a aprender. Comportar-se enquanto tal é um grande desafio. $\mathrm{Na}$ verdade, é muito mais fácil fazer um discurso que tenha sido anteriormente preparado que improvisar, no local, respostas às perguntas dos visitantes, a concepções errôneas ou dúvidas. Isso requer conhecimento científico profundo e confiança para desafiar o visitante a expor suas ideias para, então, construir a partir delas; requer uma familiaridade suficiente com a ciência e tecnologia para ser capaz de 'esquecer' as equações e as formulações padronizadas e conversar sobre ciência com o visitante - em vez de tentar ensinar ciência. Isso demanda uma boa formação científica e tecnológica, embora na maioria das vezes isso não seja suficiente: são essenciais prática e capacitação específicas para desenvolver a improvisação científica com precisão e as habilidades para dialogar sobre ciência. Um 'explicador' deveria motivar em vez de explicar, questionar em vez de responder, desafiar em vez de apresentar soluções, mas nós não vamos chamar estas pessoas de 'questionadores' nem de 'motivadores' ou 'desafiadores'. (p. 31).

\section{Carvalho e Porto (2013) apontam que}

o grande desafio para escolas e instituições culturais é incentivar a frequência de crianças, jovens e adultos com o objetivo de transformar o museu em um local de encontro, de prazer e de informações. $O$ pressuposto para a qualidade da ação educativa é que esta deve estar comprometida com a vida, com o humano, com a solidariedade e com a transformação, pois a habilidade de empreender diferentes leituras sobre esses espaços e acervos amplia a capacidade de compreensão do mundo. (p. 148).

Tendo em vista as reflexões desenvolvidas anteriormente acerca dos aspectos positivos e dos pontos que podem ser melhorados no Programa Escola e Museu, dedico-me, a seguir, à apresentação e análise das observações das visitas realizadas pelas escolas participantes e as experiências vivenciadas pelos 
diferentes grupos. Além disso, também serão abordadas as entrevistas realizadas com os docentes, nos diferentes equipamentos culturais participantes do Projeto Escola e Museu, abordando o contexto da prática.

\subsection{Uma análise do contexto da prática}

No desenvolvimento do trabalho de campo, a partir das vinte e seis observações e entrevistas ${ }^{68}$ realizadas com os docentes participantes do Projeto Escola e Museu, foi possível constatar que esse grupo se configurava como leitor ativo da construção de sentido dos "textos" da política emitida pela SME/RJ e, desta forma, reformulava e reescrevia os mesmos. De acordo com Ball e Bowe (1992, p.22)

os profissionais que atuam no contexto da prática [escolas, por exemplo] não enfrentam os textos políticos como leitores ingênuos, eles vêm com suas histórias, experiências, valores e propósitos (...). Políticas serão interpretadas diferentemente uma vez que histórias, experiências, valores, propósitos e interesses são diversos. A questão é que os autores dos textos políticos não podem controlar os significados de seus textos. Partes podem ser rejeitadas, selecionadas, ignoradas, deliberadamente mal entendidas, réplicas podem ser superficiais etc. Além disso, interpretação é uma questão de disputa. Interpretações diferentes serão contestadas, uma vez que se relacionam com interesses diversos, uma ou outra interpretação predominará, embora desvios ou interpretações minoritárias possam ser importantes.

Concordando com Alice Casemiro Lopes (2005) sobre a necessária superação das concepções que definem o Estado como produtor absoluto das políticas de currículo, e as escolas enquanto meras executoras subordinadas dessas políticas, proponho a reflexão sobre a atual política de formação cultural proposta pela SME/RJ a partir da compreensão e adaptação feitas no contexto da prática sob três aspectos: i) a seleção dos docentes participantes (gestores escolares); ii) a seleção dos alunos participantes (docentes) e iii) a atuação dos equipamentos culturais parceiros do Projeto Escola e Museu. Cada uma dessas unidades será detalhada a seguir e buscou-se compreender de que forma recebiam as orientações da SME/RJ e as praticavam.

Assim, distanciando-me da compreensão de que a função da escola seria simplesmente implementar as políticas da forma como chegam às unidades

\footnotetext{
${ }^{68}$ Apesar de perfazer um total de vinte e seis entrevistas, o número de docentes entrevistados foi igual a vinte, pois alguns deles foram entrevistados mais que uma vez em diferentes equipamentos culturais para serem obtidas informações sobre a mediação.
} 
escolares, e aproximando-me da visão de que os professores são considerados também autores da política na medida em que exercem um papel ativo na recontextualização, esta pesquisa se propõe a olhar para a prática dos professores e das instituições participantes durante as ações do Projeto Escola e Museu. Conforme afirma Mainardes (2006, p. 60), o contexto da prática exige a análise de como a política é reinterpretada pelos profissionais que atuam no nível micro e ainda a análise das relações de poder, resistências etc. Adiante, são apresentados trechos das entrevistas, preservando em sigilo a identidade dos docentes e das escolas participantes.

\subsubsection{A seleção dos docentes participantes}

Ao questionar os professores sobre o modo como chegaram ao projeto Escola e Museu se houve, por exemplo, uma indicação da direção, foram reveladas múltiplas estratégias que apontaram para uma reinterpretação da política, em conformidade com a realidade de cada unidade escolar, como é observado nos trechos das entrevistas realizadas ao longo do trabalho de campo.

Docente 3: A diretora disse que tinha esse projeto, aí a gente sentou, conversou, como eu sou professor de história, a gente viu que era uma boa colocá-los nesse projeto é, só que claro, sem saber que turma que a gente poderia trabalhar. Mas de qualquer forma foi a direção e aí ela correu atrás, foi no apagar das luzes e aí foi assim que eu fiquei sabendo. A diretora não me indicou, ela sentou comigo e perguntou se eu queria.

Docente 5: Foi. A direção apresentou para os professores alguns roteiros, selecionou aqueles que estavam disponíveis para fazer a visitação, não houve assim um preparo específico, foi mais uma informação, ela passou alguns folders, mandou e-mail para o pessoal e quem estava disponível se prontificou.

Docente 6: Foi indicação da nossa coordenadoria regional de educação, mandaram um e-mail para gente, para que a gente participasse do projeto. Eu sou a professora responsável, por conta de eu ser coordenadora pedagógica, também, da escola, então eu que normalmente tomo conta dos passeios de maneira geral. Então a gente selecionou a turma, para ver.

Docente 7: É, metade, metade, a direção repartiu a informação com um grupo de professores para ver se alguém se interessava, eu parte me interessei, parte foi a negociação de ir aos sábados e poder contar com algumas folgas, não sei nem se você pode gravar isso. (...) É, mas, eu super me interessei pelo passeio mesmo, no início tem essa questão do interesse, mas depois foi ótimo, mesmo aos sábados, não foi uma perda de sábado como a gente tende a achar no início.

Docente 8: A coordenadora da minha escola fez um curso de formação e aí ela foi selecionando as professoras, passando o material, explicando do que se tratava. Como a gente já tinha um trabalho lá sobre essa questão do Rio de Janeiro, eles 
conhecerem outros lugares no Rio de Janeiro, a gente achou que poderia ser uma boa ideia, incluir história, artes, ciências, um projeto interdisciplinar da escola.

Docente 16: A direção me falou, e eu quis participar, porque também era no sábado, o professor tinha que querer participar, também pensando em visitações a outros locais, os alunos não saem e é muito difícil conseguir ônibus, então, meu objetivo maior foi tentar uma, que os alunos conseguissem sair do ambiente escolar.

Em alguns relatos foi possível notar um movimento mais vertical, através de um convite diretamente da CRE ou da Secretaria Municipal de Educação e, em outros, um movimento mais horizontal, com a apresentação da proposta do Projeto Escola e Museu pela direção para que os professores pudessem manifestar o interesse em participar. Ball (2001, p.108) considera que "durante os últimos vinte anos, a gestão tem sido um mecanismo chave tanto na reforma política quanto na reengenharia cultural no setor público". Desta forma, muitas vezes, a interlocução entre a SME/RJ e os professores é desempenhada pela equipe de gestão da unidade escolar. Ou seja, é uma política que não envolve todas as esferas que atuarão na execução da mesma.

Docente 9: ... foi indicação da direção. A secretaria de educação mandou e-mail e aí ela me indicou, como eu era professor do oitavo ano, me indicou para o projeto. (...) Bom, quando ela fez o convite eu também não sabia o que era, ela falou só tem, tem que escrever hoje, é isso, pronto e acabou, me deu o papel eu não sabia nem para o que era. Nas visitas que a gente fez, os professores vieram antes. ... no curso, aí que eu fiquei encantado, porque alguns museus eu já conhecia, mas outros eu nem nunca tinha ouvido falar.

O relato do docente 9 , no que diz respeito ao conhecimento (ou sua falta) sobre os equipamentos culturais parceiros do Projeto Escola e Museu, merece uma reflexão. Com a precarização do trabalho docente e as questões relacionadas à baixa remuneração, muitos professores precisam ampliar o seu tempo em sala de aula trabalhando nas diversas redes de ensino, o que diminui o tempo, por exemplo, para o lazer e visitas aos espaços de educação não formal. Além disso, Maria Margaret Lopes (1991) afirma que uma das razões que levam os professores a não incentivar a ida aos museus é também o desconhecimento ou a falta de recursos nas escolas para integrar suas visitas aos currículos escolares.

Atualmente, muitos equipamentos culturais oferecem atividades especiais voltadas especialmente para os docentes como um instrumento que contribui para a formação docente, possibilitando também agendamento para os alunos dos 
professores que fazem o curso com a oferta, em alguns casos, do transporte. É certo que essas iniciativas visam ampliar o público dos museus e centros culturais.

Apoiando-me no trabalho de Ghanem (2008), cabe destacar que comungo da ideia de que no interior de cada sistema de educação básica, no caso aqui apresentado, o municipal, há uma forte hierarquia administrativa, na qual

os órgãos do nível superior determinam diretrizes de política, os do nível intermediário exercem controle quanto à execução das diretrizes e, no nível inferior, pretende-se que as diretrizes sejam executadas, pois nele se situam os estabelecimentos em que ocorrem diretamente as práticas educacionais. Pretensão que se vê seguidamente frustrada pelo próprio fato de que as pessoas encarregadas da execução não são também as que concebem as diretrizes a serem cumpridas. (p. $65)$.

Durante conversas informais com os docentes entrevistados, quando o gravador estava desligado, dois deles pareceram não entender o processo de escolha do professor representante e, nem mesmo, da escola participante. Ambos acreditavam que a escola e eles próprios estavam participando pelo segundo ano consecutivo por terem desenvolvido um bom trabalho no ano anterior. Esse aspecto revela o quanto os professores, de modo geral, desconhecem o critério de escolha desenvolvido na ação da SME/RJ. Em 2015, foram selecionadas escolas localizadas em áreas conflagradas e, em 2014, escolas com baixo rendimento escolar, logo, tais docentes estavam em escolas que atendiam aos dois critérios.

Outro aspecto interessante é pensar que a indicação ocorreu por parte da direção com base na disciplina que, de modo geral, se envolve nas questões relacionadas à formação cultural: artes, como é o caso do docente 18. Esse é um aspecto muito importante porque as outras áreas disciplinares também podem promover formação cultural, no entanto, no âmbito das escolas, tal tarefa ainda é atribuída aos docentes de artes, em especial, visuais. Em alguns casos, ocorre uma busca pela escolarização museal e o professor responsável pelas atividades em museus e centros culturais são aqueles que podem ter algum conteúdo sendo trabalho em determinado momento do ano letivo que justifique o objetivo da visita.

Docente 18: A direção me indicou. Foi uma solicitação da CRE. Então, a direção indicou alguns professores, como sou professor de arte, a direção me indicou.

Ainda sobre a questão docente, nem sempre o professor responsável pelo Projeto Escola e Museu na unidade escolar, e que participou do processo de 
formação nos equipamentos culturais, foi o que acompanhou a turma durante o roteiro interativo. No documento analisado, verifica-se a seguinte determinação:

Ressaltamos a importância de que os professores envolvidos na formação acompanhem os seus grupos até o final do Projeto. Na responsabilidade do acompanhamento por todo o circuito, recomendamos que o/a Professor/a tenha o domínio dos objetivos do Projeto, visando garantir a atividade multiplicadora na escola. (Fragmento presente no PPT cedido pela equipe de Extensividade da SME, 2014).

Quando questionados sobre a ausência dos responsáveis, uma das justificativas era a de que a atividade aconteceu em um dia que não era o do professor na escola e o mesmo não conseguiu fazer uma troca. Essa é uma questão importante porque nem todos os docentes trabalham em regime de dedicação de 40h semanais para a SME/RJ; logo, o cotidiano dos docentes, principalmente dos que atuam nas disciplinas específicas do segundo segmento, é dividido entre diferentes unidades escolares dentro de uma mesma rede ou, até mesmo, entre as esferas públicas e privadas.

Em pesquisa realizada por Barbosa (2012, p. 398-399) acerca das implicações dos baixos salários para o trabalho dos professores brasileiros, a autora destaca que

Uma das consequências da intensa jornada de trabalho é o aumento da rotatividade e itinerância do professor pelas escolas. Para complementar o salário recebido por uma carga horária de 25 ou 30 horas, por exemplo, os professores são levados a assumirem mais aulas onde houver disponibilidade, podendo ser em outras escolas da rede estadual, municipal ou particular ou, algumas vezes, acumulando mais de um cargo na mesma rede. Com isso, os professores ficariam sujeitos a ministrar uma parte de suas aulas (a carga horária de trabalho suplementar) onde houver vagas o que, por sua vez, pode variar de ano para ano. Assim, as escolas públicas assistem a uma grande rotatividade de professores. Além disso, é comum que os docentes assumam aulas em diversas escolas ao mesmo tempo, como é o caso dos professores que estendem sua jornada para complementar seus salários, o que faz desse profissional um trabalhador itinerante.

As licenças solicitadas por alguns professores também se configurou como outra razão apresentada para a ausência dos docentes responsáveis.

Docente 10: Na verdade, quem começou na escola foi a professora (nome da mesma) que é professora de artes, e ela levou a proposta, mas infelizmente ela precisou se licenciar e eu acabei assumindo no meio do caminho.

A condição de saúde dos professores é muitas vezes desconsiderada pelas políticas públicas educacionais, apesar de ser retratada na literatura educacional, 
principalmente quando são discutidas a qualidade do trabalho docente e a motivação do profissional da educação. Barbosa (2012, p. 399) relata que

outro fator que decorre da excessiva jornada de trabalho são os problemas de saúde, que cada vez mais acometem os professores. $\mathrm{O}$ desgaste provocado pelo excesso de trabalho e pela necessidade de se deslocar constantemente de uma escola a outra contribuiria para causar esses problemas que, por sua vez, prejudicam muito a prática docente, porque desencadeiam licenças médicas ou faltas diárias e, consequentemente, a descontinuidade do trabalho iniciado com os alunos.

Por fim, vale destacar a fala do docente 16, afirmando que foi indicada pela diretora, mas o que motivou sua aceitação ao projeto e permanência foi a possibilidade de garantir transporte para que seus alunos pudessem sair do ambiente escolar. Carvalho $(2009,2016)$ já apontava que a disponibilidade de transporte se apresenta como um aspecto fundamental para a frequência de alunos, especialmente das classes populares, aos equipamentos culturais. Infelizmente, ainda se registra a dificuldade na obtenção de transporte para o deslocamento dos alunos da rede pública para os museus, fazendo com que os docentes usem estratégias, como a participação no Projeto Escola e Museu, para garantir o acesso de seus alunos aos espaços não formais de educação. Além disso, há graves problemas relacionados ao transporte público na cidade do Rio de Janeiro: o aumento das tarifas, a falta de composições para atender alguns ramais, a questão da falta de segurança nas estações e bairros vizinhos à ferrovia, dentre outros.

Desta forma, fica evidente que as situações do cotidiano e a realidade das unidades escolares influenciam fortemente o contexto da prática das políticas educacionais.

\subsubsection{A seleção dos alunos participantes}

De acordo com as diretrizes do Projeto Escola e Museu, as atividades propostas destinam-se aos alunos da rede municipal de educação do Rio de Janeiro matriculados no $8^{\circ}$ ano do ensino fundamental. No entanto, uma mesma escola pode ter mais de uma turma da mesma série e, para o desenvolvimento do Projeto, apenas um ônibus para o transporte de alunos foi disponibilizado, totalizando 40 alunos por escola.

Cada escola do Projeto indicará 01 (uma) turma do $8 .^{\circ}$ ano. Essa mesma turma participará de um circuito interativo pelos museus citados e terá o compromisso de socializar essa experiência por meio da elaboração de painéis, debates, exposições, 
materiais criativos entre outros, com os demais alunos da escola. (Fragmento presente no PPT cedido pela equipe de Extensividade da SME, 2014).

Ao indagar os docentes acerca do critério de seleção dos alunos que participariam do roteiro de visitação aos museus e centros culturais, ficou nítida a reinterpretação no contexto da prática, como é possível observar nas falas apresentadas a seguir.

Docente 1: O critério de seleção foi, nós pensamos uma turma que tivesse o maior aproveitamento nesse passeio.

Docente 2: No caso da minha escola eu vi que cada escola é... tomou uma decisão. $\mathrm{Na}$ escola estava acontecendo assim, parece que eles estavam disponibilizando os ônibus só para o turno da tarde, então a turma do oitavo ano da tarde está sendo muito privilegiada.

Docente 3: São... quarenta, eu tentei pegar vinte de cada turma, porque a gente só tem duas turmas. (...) São duas turmas, o critério, é, participação em sala, comportamento porque eles vão estar trabalhando, eles vão para locais públicos, aqueles alunos mais indisciplinados, que eu sei que não tem um comportamento social muito bom, eu deixei para segundo plano, a não ser que algum ou outro dos selecionados primeiramente não pudessem ir, mas... E outra coisa importante, foi selecionado também se queria participar.

Docente 4: As visitas foram programadas para os alunos de oitavo ano que eu sou a professora que foi escolhida para levar os alunos e até mesmo fazer essa intermediação. É... eu utilizei muitas vezes os alunos do oitavo ano. Como a nossa escola é uma escola que nós temos uma dificuldade já muito grande de ganhar passeios com facilidade, eles moram muito a ermo do centro do Rio e dessa questão da cultura..., do cultural em geral, eu pensei que poderia ser bom trazer outras turminhas também, e como foi o último passeio, por que não? Vamos deixar os do sexto ano também dar uma olhadinha para ver, para eles terem essa experiência, contato de saída da escola, além dos muros da escola, para eles terem vivência com gente, com pessoas, com espaços diferentes, com estrutura diferente, iluminação diferente e outro ambiente, então eu pensei neles e não deu tempo de eu criar, hum... fazer uma aula que fosse voltada para tecnologia ainda porque não estava no meu plano de curso, mas eu vi que aqui eles tiveram uma aula e foi muito bom.

Destaco a passagem da docente 4 em que manifesta a vontade de levar o sexto ano para dar uma "olhadinha" no museu. A restrição legal aos alunos do oitavo ano não impede os professores de desejarem que estudantes de outras séries participem do programa, que é uma oportunidade de formação cultural para viabilizar a democracia cultural, ou seja, a percepção de que todos deveriam acessar esses espaços de educação não formal. Botelho e Fiori (2005, p.9) afirmam que isso

[...] não é induzir a totalidade da população a fazer determinadas coisas, mas sim oferecer a todos a possibilidade de escolher entre gostar ou não de algumas delas. 
Isto implica colocar os meios à disposição, combater a dificuldade/impossibilidade de acesso à produção menos - vendávelll e o excesso de oferta da produção que segue as leis do mercado, procurando o que seria uma efetiva - democracia cultural.

Diferente da atitude de outros docentes, retratadas nas falas transcritas, foi também constatado um desejo de permitir que os alunos de uma turma considerada terrível tivessem a possibilidade de experienciar outros espaços e outras pessoas não por uma premiação, mas sim como uma possibilidade de construir identidade.

Docente 4: Essa turma é, entre aspas, é muito levada, é conhecida como o terror da escola (nome da escola), e nós, a maioria dos professores e da direção estávamos, realmente, com muito medo, muito apreensivos. Olha vocês têm que se responsabilizar, é a 1604. E então, a gente não, a gente vai abraçar essa causa, a gente vai levar, e a gente vai ver que, tenho certeza que vai dar tudo certo.

Docente 5: Nesse momento aqueles que eram, tinham as melhores notas, como uma forma de premiação, até para incentivar que eles estudassem, não é que veio todo mundo dez, mas a gente tentou premiar aqueles que tinham melhores resultados.

Docente 6: O critério, na verdade, foi o seguinte: a gente selecionou essa turma porque é uma turma muito unida, porque se a gente selecionasse alunos, dos melhores, porque tem determinadas escolas que estão fazendo isso, a gente não quis porque não ia ter essa integração, e a turma é integrada, entendeu? E é uma turma que ao mesmo tempo merece, porque é uma turma boazinha, uma turma que participa, uma turma bem comportada que respeita, então a gente selecionou esse oitavo ano exatamente por isso.

Docente 9: É, como tem cinco turmas na escola, eu preferi selecionar um grupo de cada turma em vez de escolher uma turma só, e aí eu vi talvez os melhores rendimentos, os comportamentos, também o interesse, que alguns não estavam tão interessados. Falava em museu: Ah, coisa velha, coisa chata, né! Aí também ter achado interesse, comportamento, todo esse conjunto aí fez a listagem.

Docente 11: Foi só a 801, porque ano passado nós fizemos com duas turmas e não ficou muito legal, então a gente achou melhor esse ano tentar só com uma turma.

Docente 13: Oitavo e nono anos. Na verdade, não necessariamente todos estão fazendo o circuito inteiro, mas aí, em geral, todos têm dois passeios pelo menos.

Docente 18: O interesse deles, a disciplina (comportamento), a nota. É muito difícil convence-los a participarem, não possuem interesse. Eles dizem visitar museu?!? (imitando a cara de desaprovação dos alunos). Além disso, ontem teve tiroteio na comunidade, a escola não funcionou, nem pudemos fazer a visita no MAR, acredito que muitos não conseguiram chegar a escola hoje. 
No caso do critério de seleção dos alunos participantes, é possível perceber que os professores usaram diversas estratégias: comportamento, restrição por turno, premiação por boa conduta e por bom desempenho, a tentativa de contemplar alunos de outras séries pelo fato da escola não conseguir muitas atividades fora da sala de aula e o interesse pela atividade proposta.

Dentre as estratégias utilizadas pelos docentes, duas delas são muito recorrentes: a premiação pelas atitudes e a premiação por desempenho. Problematizando esses dois pontos, parece que alguns professores não levam em consideração os fatores que explicam o insucesso escolar e o mau comportamento de algumas turmas, exceto uma professora (docente 4) que considera as atividades em outros espaços como um aspecto motivador e importante, que pode fazer diferença justamente para os alunos da turma que é considerada "o terror da escola”. Segundo Maria Margaret Lopes (1991, p. 6),

São inúmeros os testemunhos ou desabafos de professores bem intencionados que desanimam de ir a museus porque, segundo seu modo de ver, as crianças não se interessam, não se comportam, não aprendem; e, como se trata de uma grande responsabilidade (e de uma tarefa "ingrata"), preferem, mesmo com seus poucos recursos, ficar na sala de aula, onde se sentem mais seguros do que em face da realidade desconhecida e difusa dos museus, que não se deixa dominar facilmente.

As pesquisas desenvolvidas pelo PISA (2002) comprovam que o nível socioeconômico médio dos alunos está fortemente relacionado às questões de desempenho e à presença de recursos escolares relevantes para que a aprendizagem aconteça. Logo, a seleção dos alunos com boa postura e melhores resultados pode estar beneficiando aqueles que apresentam maior nível socioeconômico, gerando mais desigualdade intraescolar. Para Soares e Andrade (2006),

Hoje, reconhece-se que os fatores que determinam o desempenho cognitivo do aluno pertencem a três grandes categorias: a estrutura escolar, a família e características do próprio aluno. Nesse campo de pesquisa educacional as melhores análises incorporam todos esses fatores ao invés de se apoiar em apenas uma área. $\mathrm{Ou}$ seja, nem os fatores extra-escolares conseguem sozinhos explicar o desempenho cognitivo, nem a escola faz toda a diferença como querem fazer crer determinadas campanhas publicitárias de escolas particulares. (p. 109).

O Projeto Escola e Museu, em seu desenho, tem um foco na promoção da equidade através do crivo utilizado para a seleção das escolas participantes. No entanto, a ação de alguns docentes parece estar colaborando para a promoção de desigualdades dentro do ambiente escolar quando olham apenas para os critérios 
desempenho e comportamento na escolha dos alunos que participarão do roteiro cultural.

Outro aspecto relevante na fala dos docentes 9 e 18 é a concepção de museu por parte de alguns alunos, relacionando tal espaço ao velho. Esse tipo de pensamento não é recente na sociedade, mas sua concepção tem sofrido alterações ao longo do tempo. Sempre coube aos museus a função de recolher e preservar o patrimônio, garantindo, assim, sua conservação ao longo das gerações, aspecto que também contribuiu para a relação estabelecida pelos alunos ao associarem museu a lugar de "coisa velha", caracterizando um desafio a ser vencido pelos equipamentos culturais na tentativa de atrair novos públicos. Existe uma tensão entre as ações de guardar, estudar e conservar e o modo como as atividades são desenvolvidas para que os objetos presentes nos museus estejam acessíveis à população como ferramentas para a construção de novos conhecimentos, novos pensamentos e sensibilidade. Segundo Oleiro (2005),

e se é verdade que a função de salvaguarda patrimonial se mantém como base do museu, à qual se foram associando novas funções educativas e outras funções sociais, é também verdade que nas últimas décadas os museus, um pouco por todo o mundo, têm vindo a ser confrontados com crescentes desafios que questionam a sua forma de organização, a sua atitude perante a sociedade, a forma de olhar as colecções e a maneira de se darem a conhecer aos públicos. (p. 9)

Carvalho e Porto (2013) também trazem contribuições nesse sentido ao analisarem os trabalhos desenvolvidos em um curso de especialização em educação infantil. Em um deles, Gameiro (2011) entrevistou professoras acerca da concepção museal, percebendo que em algumas falas os museus eram tomados como lugar de coisas velhas, de aborrecimento ou lugar só para uma elite. Aprofundando a pesquisa, a autora percebeu que a resistência aos museus era proveniente de uma falta de hábito, onde docentes nunca haviam entrado em contato com esse tipo de equipamento cultural. Ainda na pesquisa de Carvalho e Porto (2013), ressaltam que uma das professoras pesquisadas por Gameiro (2011) reconhece que o espaço museal

poderia assumir outra dimensão se houvesse uma formação ampla que incluísse a cultura como direito. Quando não há esse acesso, o olhar fica marcado pela exclusão, quando esse conhecimento é negado, o contato com ele pode provocar medo e insegurança (p. 142). 
Apesar da pesquisa acima citada tratar da concepção de professores, a lógica acerca do afastamento e resistência dos alunos apresentada pelos docentes 9 e 18 também pode ser fruto de um sentimento de não pertencimento aos espaços museais, em consequência de uma política que não atue no sentido de garantir a cultura como um direito de todos. As políticas públicas no Brasil deveriam tomar por base a concepção democrática em defesa da juventude e dos jovens como sujeitos de direitos, inclusive culturais.

Não menos importante, é a questão da violência nas proximidades das escolas. Para além das condições discutidas acima que podem ocasionar o afastamento dos alunos em relação aos equipamentos culturais, como observado pelo docente 18, os adolescentes ainda enfrentam uma dura realidade cercada por tiroteios, o que inviabilizou o acesso aos equipamentos culturais em alguns casos. Essa é uma situação cotidiana. Em reportagem ${ }^{69}$ veiculada no dia 16 de julho de 2017, a Secretaria Municipal de Educação afirmou que em apenas oito de cento e cinco dias do ano letivo, a rede funcionou sem interrupção por episódios violentos como, por exemplo, tiroteio, toque de recolher, assalto, operação policial). Além disso, 382 das 1.537 escolas tiveram de fechar ou interromper atividades pelos mesmos motivos.

Aprofundando essa reflexão, torna-se evidente que quando as políticas públicas educacionais chegam ao contexto da prática sofrem recontextualizações por parte dos sujeitos, que, como no caso da pesquisa aqui desenvolvida, apresentaram diferentes motivações na seleção dos alunos participantes, tanto por parte dos docentes quanto gestores das escolas, podendo ocorrer movimentos distintos: aceitação, resistência e adaptações de múltiplas formas, transformando o texto da política em ação.

\subsubsection{Os equipamentos culturais e a implementação da política}

Não só docentes e gestores recontextualizaram, no âmbito da prática, as diretrizes do Projeto Escola e Museu, mas também os setores educativos dos equipamentos culturais participantes do roteiro.

\footnotetext{
69 Disponível em: http://brasil.estadao.com.br/noticias/rio-de-janeiro,violencia-ja-interrompeuaulas-em-25-das-escolas-municipais-do-rio,70001892736. Acesso em: 23 jul. 2017.
} 
No entanto, antes de trazer essa discussão, é importante apresentar algumas informações sobre cada um dos equipamentos culturais participantes. As sete instituições parceiras configuram-se como museus e centros culturais reconhecidos. Dedico-me então a situar cada uma das instituições, bem como apresentar as exposições veiculadas e as ações desenvolvidas para o acolhimento dos alunos e docentes e para a mediação, no momento de realização da pesquisa.

\section{A) Centro Cultural Banco do Brasil (CCBB)}

O prédio do CCBB (figura 7) Rio de Janeiro, localizado no centro da cidade, esteve ligado às finanças e aos negócios. Foi a sede da Associação Comercial do Rio de Janeiro. Na década de 1920 foi reformado e passou a pertencer ao Banco do Brasil.

No final da década de 1980, o Banco do Brasil decidiu pela sua preservação ao transformá-lo em um centro cultural, tendo sido inaugurado em 12 de outubro de 1989, tornando-se uma das instituições culturais mais visitadas do Brasil. Em junho de 2015, por exemplo, atingiu novo recorde de público (13.112 pessoas em apenas um dia) ao receber a exposição temporária e gratuita "Picasso e a Modernidade Espanhola - Obras da Coleção do Museu Nacional Centro de Arte Reina Sofía". A mostra que estava disponível no momento em que os alunos participantes do Projeto Escola e Museu realizavam o circuito nos sete equipamentos culturais, e período em que foram realizadas as observações para o trabalho de campo, era composta por noventa obras datadas de 1910 a 1973 , que foram divididas em oito módulos temáticos, possibilitando, assim, conhecer um pouco sobre a trajetória do artista: os desenhos, a obsessão pela figura feminina, a habilidade na criação de imagens por meio de figuras de geometria, a associação à figura do minotauro, e esboços e pinturas que serviram de preparação para "Guernica"70. A curadoria foi de Eugenio Carmona.

\footnotetext{
${ }^{70}$ Reflejo fiel de una época y de unas luctuosas y dramáticas circunstancias, el lienzo Guernica nació para formar parte del Pabellón Español en la Exposición Internacional de París, de 1937. El motivo que impulsó a Pablo Picasso a realizar la escena representada en esta gran pintura fue la noticia de los bombardeos efectuados por la aviación alemana sobre la villa vasca que da nombre a la obra, conocidos por el artista a través de las dramáticas fotografías publicadas, entre otros diarios, por el periódico francés L'Humanité. A pesar de ello, tanto los bocetos como el cuadro no contienen ninguna alusión a sucesos concretos, sino que, por el contrario, constituyen un alegato genérico contra la barbarie y el terror de la guerra. Concebido como un gigantesco cartel, el gran lienzo es el testimonio del horror que supuso la Guerra Civil española, así como la premonición de lo que iba a suceder en la Segunda Guerra Mundial. La sobriedad cromática, la intensidad de todos y cada uno de los motivos, y la articulación de esos mismos motivos, determinan el extremado
} 
No entanto, cabe esclarecer que, quando os docentes participantes e responsáveis pelo Projeto em suas escolas foram capacitados, no início de 2015, tiveram acesso à exposição permanente do CCBB e não uma formação sobre as obras de Picasso e a Modernidade Espanhola.

Figura 7: Centro Cultural Banco do Brasil - Rio de Janeiro

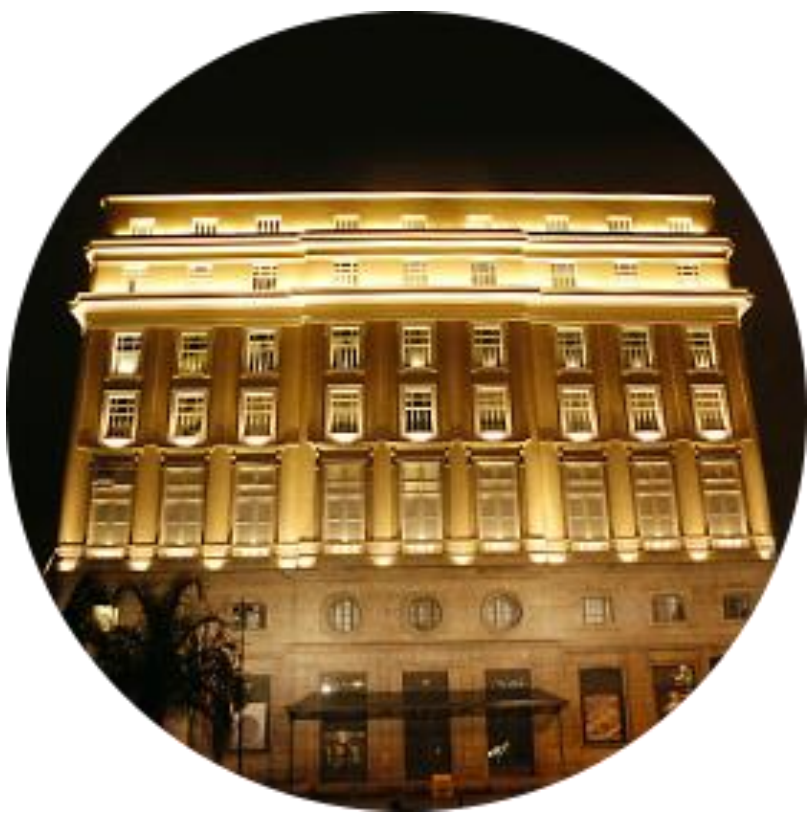

Fonte:CCBB/ Divulgação ${ }^{71}$

$\mathrm{Na}$ chegada ao centro cultural, alunos e docentes eram recebidos por algum mediador e conduzidos ao guarda-volumes para que deixassem seus pertences. Em seguida, eram conduzidos a uma sala do setor educativo e, após o acolhimento, eram desafiados a falar sobre o local, o que achavam que havia ali, o que veriam. Após este diálogo com o grupo, o mediador trazia uma réplica tridimensional da obra que retratava Marie Thérèse, modelo e amante de Picasso, e apresentava algumas informações sobre o cubismo, interpretação, arte e quem foi o artista (figura 8).

carácter trágico de la escena, que se iba a convertir en el emblema de los desgarradores conflictos de la sociedad de nuestros días. Disponível em: http://www.museoreinasofia.es/coleccion/obra/guernica. Acesso em: 22 abr. 2017.

${ }^{71}$ Disponível em: http://culturabancodobrasil.com.br/portal/wp-content/themes/ccbb/images/imgrj-historia-home-1.png. Acesso em: 26 jul. 2017. 
Figura 8: Mulher sentada apoiada sobre os cotovelos em "Picasso e a Modernidade Espanhola"

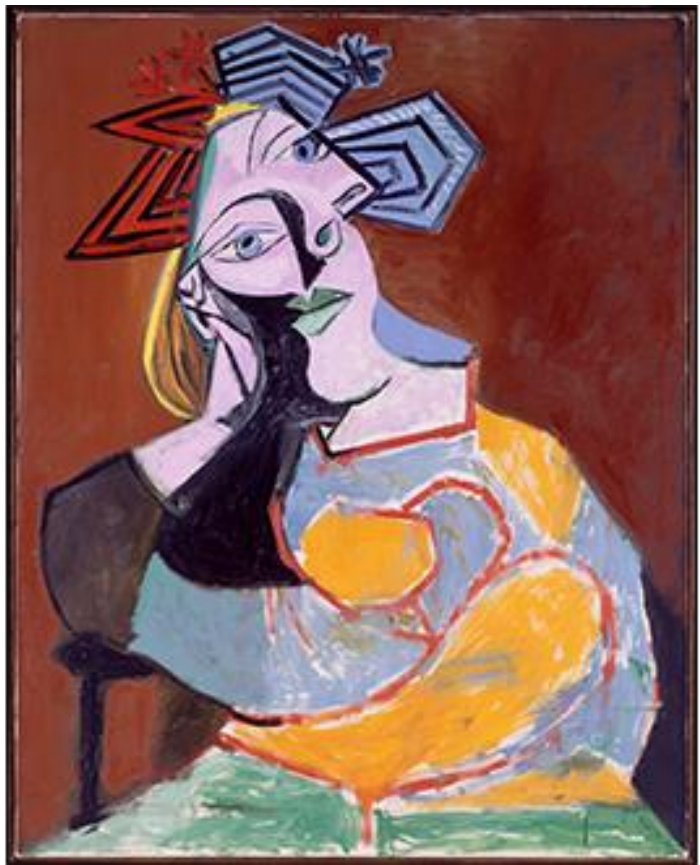

Fonte: CCBB/Divulgação ${ }^{72}$

Uma etapa marcante nessa rotina do $\mathrm{CCBB}$ era o momento em que falavam sobre as regras como, por exemplo, não falar alto, não tocar nos objetos, não usar o telefone e não fotografar, como pode ser observado no trecho do caderno de campo destacado a seguir.

Mediador (CCBB): Aqui não é a Disney (todos riram), então não pode correr, precisa respeitar. Esse espaço é de vocês, mas é de outras pessoas também, então precisa respeitar. Não pode fotografar. (indignação geral). Vou explicar o porquê, essas obras valem muito dinheiro, cada reprodução de uma obra é preciso pagar os direitos autorais que é $\mathrm{R} \$ 1500$ por cada foto. (Todos se olham assustados). Aproveitem a visita, não fiquem no celular.

O mediador advertiu que os seguranças retirariam da exposição se as regras não fossem cumpridas

Muitas vezes, essa "lista de não" gerava certo descontentamento e desconforto, principalmente com relação ao celular, utilizado de modo frequente pelos jovens para registrar o que fazem, especialmente através das selfies ${ }^{73}$.

${ }^{72}$ http://culturabancodobrasil.com.br/portal/picasso-e-modernidade-espanhola-2/. Acesso em: 2 mar. 2017.

${ }^{73}$ A palavra selfie é definida no dicionário Oxford como "uma fotografia que a pessoa tira dela mesma, tipicamente com um smartphone ou webcam, carregada em um site de mídia social". Foi escolhida como a palavra do ano de 2013 do idioma inglês pelo dicionário Oxford. Os editores do dicionário afirmam que a palavra evoluiu do uso restrito a um nicho nas mídias sociais para um 
Segundo reportagem divulgada por uma revista semanal ${ }^{74}$, selfie é uma nova maneira de expressão e autopromoção. A mania é esticar o braço segurando o celular apontado para o rosto e espalhar a foto produzida nas redes sociais. Majoritariamente, os selfies são produzidos por jovens com idades entre 13 e 24 anos. A reportagem segue mostrando que o instituto americano Pew Internet Research, em estudo realizado em maio de 2013 com adolescentes americanos, revelou que nove em cada dez pessoas desse grupo postam os autorretratos.

Nessa mesma reportagem, a psicóloga Luciana Nunes, mestre em saúde mental, diretora do Instituto Psicoinfo e estudiosa da relação entre tecnologia e comportamento, afirma que há três grupos bem definidos de autores de selfies. O primeiro é formado pelos exibicionistas. É gente que costuma parar diante do espelho do elevador ou da academia e exibir para a câmera, por exemplo, os resultados da malhação. O segundo reúne aquelas pessoas que querem apenas mostrar seu estado de espírito - felicidade ou tristeza ao acordar, ao encontrar um amigo etc. Por fim, tem o time que quer mostrar que está em algum lugar, parque ou shopping, por exemplo, desde que a paisagem não ganhe mais importância do que o autor.

Retomando a visita ao CCBB, após a discussão introdutória sobre a exposição e estabelecidos os combinados e regras, alunos e professores eram conduzidos à área de exposição. O mediador, no entanto, retornava ao setor educativo e os alunos, com toda euforia e expectativas, seguiam apenas com os docentes o percurso da exposição.

A questão da mediação será aprofundada mais adiante, no entanto, cabe ressaltar que alguns professores queixaram-se da falta de mediação durante o percurso da exposição no CCBB e apontaram essa situação como um prejuízo na apropriação das obras de arte expostas. No entanto, tomando por base o conceito de experiência estética de Gadamer (1993, p. 6), “ compreender o que a obra de arte diz a alguém, é certamente um encontro consigo mesmo”. Então, não é um pré-requisito ter um mediador para que o encontro e o jogo entre o sujeito e a obra de arte aconteçam.

termo usado corriqueiramente por pessoas no mundo inteiro. Disponível em: http://www.bbc.com/portuguese/noticias/2013/11/131119_selfie_oxford_fn. Acesso em: 1 mar. 2017.

${ }_{74}$ Disponível em: http://veja.abril.com.br/tecnologia/selfie-e-nova-maneira-de-expressao-eautopromocao/. Acesso em: 1 mar. 2017. 
B) Centro Cultural do Poder Judiciário do Estado do Rio de Janeiro (CCPJ)

A Presidência do Tribunal da Justiça do Estado do Rio de Janeiro criou o CCPJ (figura 9) em 2009. Em novembro de 2010 o palácio, localizado no centro da cidade, foi reaberto e o CCPJ iniciou suas atividades, com o objetivo de fomentar a reflexão sobre valores de justiça, ética e cidadania, instigando a parceria entre a sociedade e o judiciário.

Figura 9: Centro Cultural do Poder Judiciário

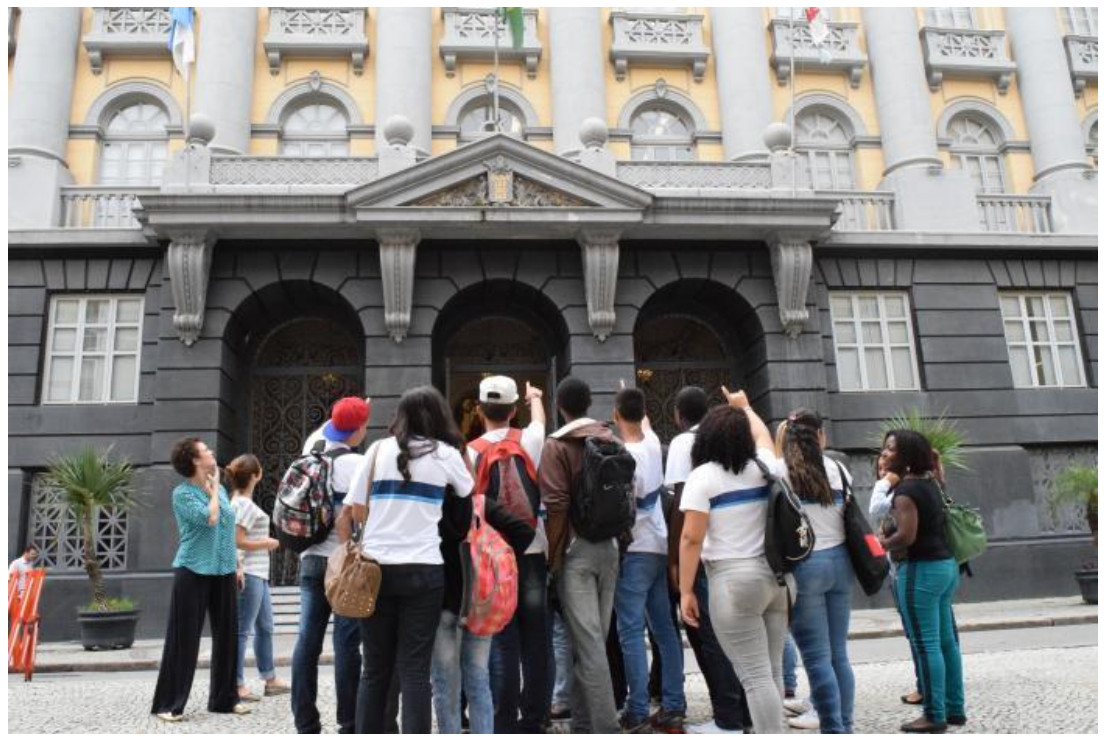

Fonte: CCPJ/ Divulgação ${ }^{75}$

A atividade oferecida aos alunos e docentes participantes do Projeto Escola e Museu era a "Por dentro do Palácio", na forma de visita teatralizada (figura 10), na companhia de personagens ícones da Justiça, pelo Antigo Palácio da Justiça. Às terças-feiras os cicerones eram atores representando Justiniano e Teodora $^{76} \mathrm{e}$, às quintas-feiras, os personagens contemplados eram Ruy Barbosa e

\footnotetext{
${ }^{75}$ Disponível em: http://www.tjrj.jus.br/cs/home/-/noticias/visualizar/11805. Acesso em: 1 mar. 2017.

${ }^{76}$ Ficha técnica dos cicerones Justiniano e Teodora: A magia do teatro invade os corredores e salões do Antigo Palácio da Justiça com a apresentação do casal de cicerones Justiniano e Teodora. Ele nascido em berço de ouro, ela uma plebeia. Uma história que reúne todos os elementos para prender a atenção dos visitantes do início ao fim. Justiniano, o Grande, o mais importante dos imperadores romanos do oriente, ou como é conhecido nos dias de hoje, do Império Bizantino, ordenou que fossem pesquisadas, organizadas e catalogadas diversas leis esparsas do direito romano em um compêndio chamado Corpus Juris Civilis. Essas leis reunidas serviam de base para o sistema jurídico de diversos países do ocidente, entre eles o Brasil. Apaixonou-se pela atriz cômica Teodora oriunda de uma família pobre que desde criança tinha que trabalhar para ajudar a mãe. Bela e ambiciosa, não aceitou a condição de amante e impeliu
} 
a Deusa Têmis ${ }^{77}$. A atividade está em curso desde janeiro de 2011, como resposta à demanda do Tribunal da Justiça do Rio de Janeiro de abrir as portas do Antigo Palácio da Justiça à população como centro de cultura e memória da Justiça. O Projeto foi inaugurado com a figura de Ruy Barbosa, em 2011; em seguida foi a vez da Deusa Têmis, em 2012; a partir de 2013, Ruy Barbosa e Deusa Têmis passaram a ser apresentados juntos; e desde 2015, os Imperadores de Bizâncio Justiniano e Teodora.

Os objetivos estratégicos do CCPJ são: aproximar o cidadão do Poder Judiciário e estimular valores de Justiça e Cidadania; e os objetivos específicos são: apresentar à população o Antigo Palácio da Justiça como espaço de cultura e memória do TJRJ; oferecer dados sobre a arquitetura, a história do prédio e do seu entorno e informar em linhas gerais sobre o funcionamento do Judiciário estadual.

Os alunos participantes do Projeto Escola e Museu e os respectivos docentes eram recebidos no hall de entrada do Palácio. Os mediadores se apresentavam como membros integrantes do setor educativo da instituição e conversavam com os estudantes sobre as expectativas, o que achavam que acontecia naquele ambiente, quem frequentava aquele espaço e contavam informações sobre a arquitetura e sobre as obras de arte do prédio e, então, chegava o cicerone do dia para conduzir a atividade.

Justiniano e enfrentar as barreiras legais que impediam a união de um nobre com uma plebeia. A promulgação de uma lei permitiu o casamento e em 527, tornaram-se o Imperador e a Imperatriz do Oriente. A apresentação da dupla de cicerones Justiniano e Teodora estreou em 2015 e, desde então, os Imperadores de Bizâncio tem a nobre tarefa de apresentar o palácio e também contar algumas façanhas do seu grandioso império. As visitas agendadas para escolas, universidades e grupos acontecem às terças-feiras, e as abertas aos sábados. Disponível em: http://www.tjrj.jus.br/web/guest/institucional/centrocultural/Projetos/por-dentropalacio/justiniano-teodora. Acesso em: 1 de março de 2017.

77 Ficha técnica dos cicerones Ruy Barbosa e Deusa Têmis: O grande jurista brasileiro Ruy Barbosa foi o primeiro personagem histórico do Projeto "Por dentro do Palácio", em 2011. Em sua segunda edição, 2012, Têmis, a deusa grega das leis e dos juramentos, foi a escolhida para ser a guia da visita. No terceiro e quinto anos consecutivos, 2013/2015, os visitantes passaram a ser ciceroneados pela dupla Têmis e Ruy Barbosa, que, juntos, apresentam os tribunais e salões do Antigo Palácio da Justiça. "Aos que não me conhecem, faço questão de apresentar-me: Ruy Barbosa" é o início da apresentação do personagem Ruy Barbosa, que após listar seus títulos, entre eles jurista e presidente da Academia Brasileira de Letras, completa: "Recebo vocês simplesmente como Ruy Barbosa, o cicerone na empreitada de guia-los pela história e magnitude deste imponente edifício que é o Antigo Palácio da Justiça". Têmis também saúda os visitantes de forma singular. Deusa das Leis e dos Juramentos, ela recebe os visitantes, a quem chama de mortais no hall do Antigo Palácio da Justiça e afirma: "Recebo-lhes, oh divinos humanos, sob os altos tetos deste saguão que me faz lembrar o Olimpo, minha casa grega, e diante destas escadarias de mármore, que nos recordam os mais belos edifícios que povoam a Magna Grécia". A apresentação da dupla de cicerones Ruy Barbosa e Têmis acontece às quintas-feiras, em visitas agendadas para escolas, universidades e grupos, e aos sábados em visitas abertas. Consulte a Projetoção. Disponível em: http://www.tjrj.jus.br/web/guest/institucional/centrocultural/Projetos/por-dentrodo-palacio/ruy-barbosa-e-deusa-temis. Acesso em: 1 mar. 2017. 
O percurso durava cerca de 50 minutos. Ao final, os alunos eram motivados a falar sobre o que mais gostaram e sobre o conceito de justiça, e era também mostrada a sala de acervo de figurinos. Nesse momento, trabalhava-se a relevância do teatro, ressaltava-se que a arte e a vida se fazem e refazem a todo tempo e abordavam-se questões que abordavam aspectos envolvendo a lei. Alguns alunos ficaram curiosos e desejaram mexer no acervo, mas, imediatamente, o mediador informara que não poderiam tocar nos figurinos.

Figura 10: Cicerones ícones da Justiça na atividade "Por dentro do Palácio"

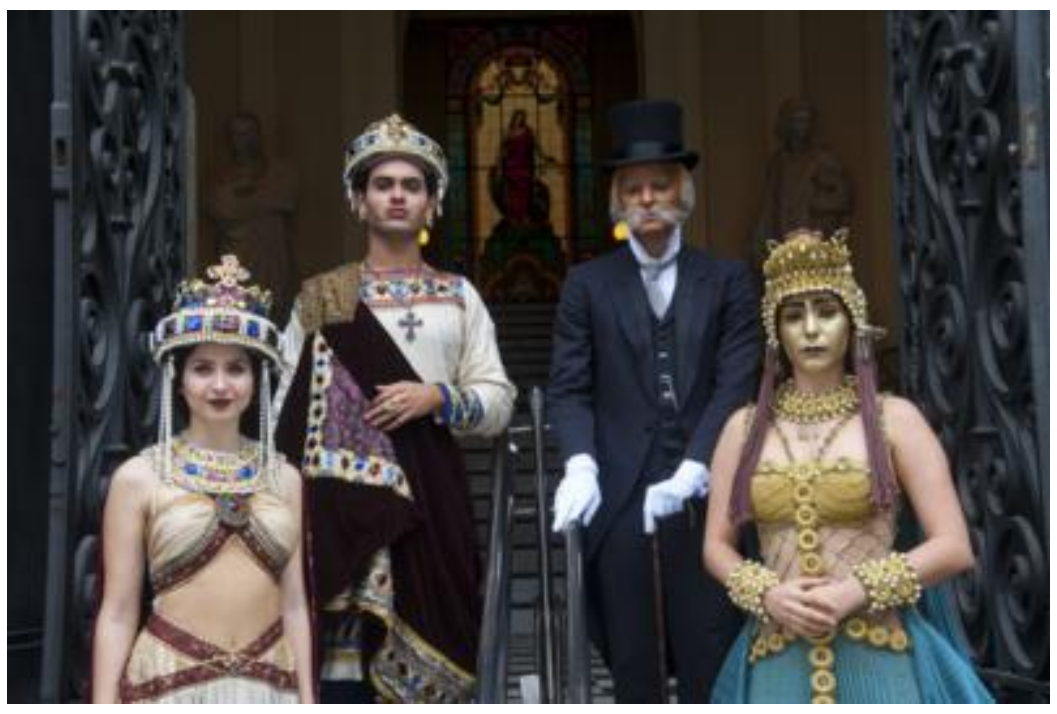

Fonte: CCPJ/Divulgação ${ }^{78}$

A visita teatralizada era encerrada dentro do teatro que compõe as instalações do prédio, com a despedida do(s) cicerone(s). Em seguida, os mediadores do setor educativo assumiam novamente e conversavam com os alunos sobre o que mais gostaram, sobre o que consideravam justiça, se a figura do(s) cicerone(s) havia provocado medo. Em seguida, era proposta a atividade denominada "Quadro Vivo", na qual viam alguns quadros como, por exemplo, “O Grito" ${ }^{\text {79 }}$ e os alunos eram convidados a falar sobre as sensações despertadas.

Por fim, os alunos eram divididos em grupo e instigados a compor uma cena que falasse sobre justiça, explicando em seguida a origem da cena, e, com o

\footnotetext{
${ }^{78}$ Disponível em: http://www.tjrj.jus.br/web/guest/institucional/centrocultural/Projetos/por-dentrodo-palacio. Acesso em: 2 mar. 2017.

${ }^{79} O$ Grito é uma série de quatro pinturas do norueguês Edvard Munch, a mais célebre datada de 1893, que representa um momento de profunda angústia e desespero existencial.
} 
apoio do mediador, era despertado um debate sobre o conceito de justiça. Essa composição teatral realizada pelos alunos é rica de sentidos. Primeiramente, contempla um documento legal que é diretriz para os currículos nacionais. De acordo com os PCN - Artes (vol. 06, 1997, p. 84),

[...] as propostas educacionais devem compreender a atividade teatral como uma combinação de atividade para o desenvolvimento global do indivíduo, um processo de socialização consciente e crítico, em exercício de convivência democrática, uma atividade artística com preocupações de organização estética e uma experiência que faz parte das culturas humanas.

Abordando o segundo aspecto, de acordo com Hermann (2010, p. 25), a educação apresenta a possibilidade de configurar uma nova face, "em que a contemplação estética atua na vida moral e a singularidade de nossos juízos articula um mundo comum com aquilo que a sensibilidade percebe em cada situação." Dessa forma, a experiência estética proporcionada pela atividade teatral proposta pela equipe do CCPJ detém a capacidade de ampliar a relação do sujeito consigo mesmo e com o mundo que o cerca.

Nessa mesma perspectiva, Gadamer assume que a capacidade de julgar dos sujeitos não é só lógica, mas estética porque envolve o juízo de gosto, que é uma capacidade de discernimento. Propor aos alunos, após a sensibilização estética promovida pela visita teatralizada, uma atividade que objetiva a reflexão do conceito de justiça é uma maneira concreta de aliar a ética e a estética na formação cultural e que pode potencializar a formação acadêmica porque leva o adolescente a construir novas lógicas de aprendizagem, alcançando um objetivo maior que é a formação integral desses adolescentes. Gadamer (1990, p. 45) afirma que

A decisão moral requer o gosto (não que está avaliação individualíssima da decisão seja o único que a determine, mas sim que se trata de um momento iniludível). Verdadeiramente implica um tato indemonstrável atinar o correto e dar à aplicação do geral, da lei moral (Kant), uma disciplina que a razão mesma não é capaz de produzir. Nesse sentido, o gosto não é fundamento do juízo moral, mas sua realização mais acabada. Aquele a quem o injusto lhe repugna como ataque a seu gosto, é também o que possui a mais elevada segurança na aceitação do bom e no rechaço ao mal, uma segurança tão firme como a mais vital de nossos sentidos.

\section{C) Centro Municipal de Arte Hélio Oiticica (CMAHO)}

O espaço está instalado em um prédio do século XIX, igualmente situado no centro da cidade do Rio de Janeiro, com galerias para exposições que recebem mostras de artistas nacionais e estrangeiros e uma sala de conferência. 
O edifício foi inaugurado em 1872 para sediar o Conservatório de Música. Dezoito anos mais tarde, o prédio foi ampliado com mais duas construções, quando recebeu o desenho atual. Em 1996, foi inaugurado o Centro Municipal de Arte Hélio Oiticica (CMAHO - figura 11) para abrigar, preservar e divulgar a obra do artista plástico Hélio Oiticica ${ }^{80}$.

\section{Figura 11: Centro Municipal de Arte Hélio Oiticica}

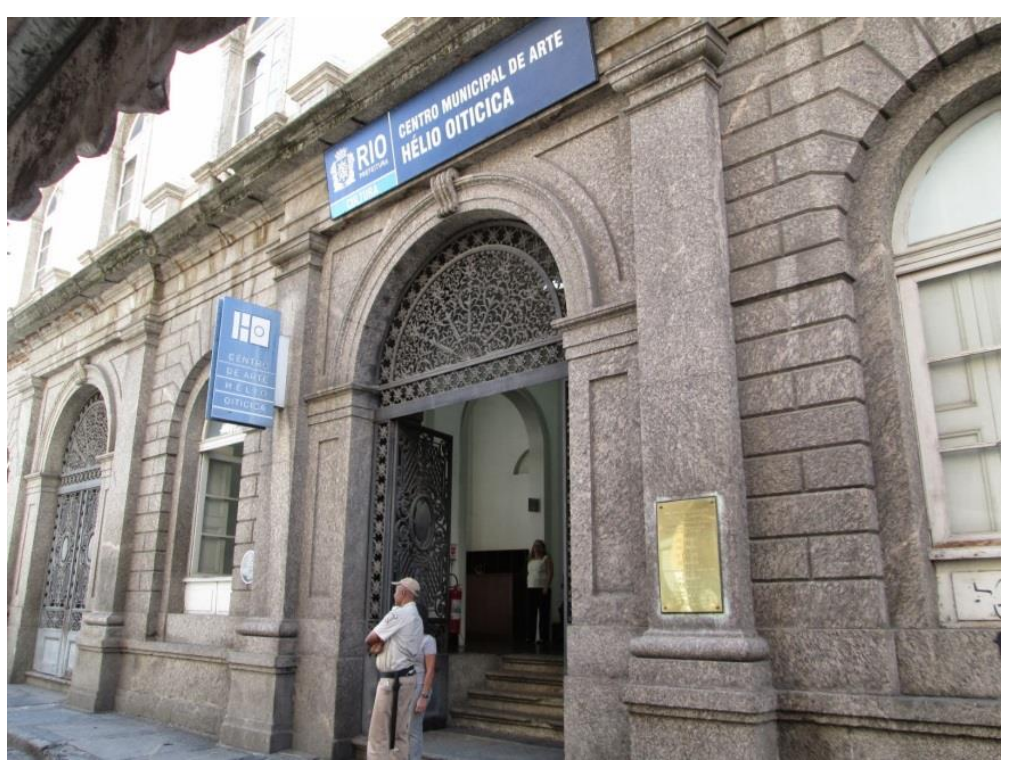

Fonte:CMAHO/Divulgação ${ }^{81}$

No momento da realização da pesquisa, os alunos e professores acessavam a exposição temporária e gratuita intitulada "Álbum de família" (figura 12), que não representava famílias tradicionais, mas buscava instigar o conceito de família e o sistema social, passando pela complexidade das relações e do mundo. O tema da família era pensado a partir de diversas óticas: cultural, política, religiosa, social, econômica, psicológica etc., e as diferentes obras debruçavam-se sobre a família e suas questões, entre elas a adoção, a violência sexual doméstica e as relações homoafetivas.

\footnotetext{
${ }^{80}$ Hélio Oiticica foi um artista carioca performático, pintor e escultor. Iniciou, com o irmão César Oiticica, estudos de pintura e desenho com Ivan Serpa no Museu de Arte Moderna do Rio de Janeiro (MAM/RJ), em $1954 . \quad$ Disponível em: http://enciclopedia.itaucultural.org.br/pessoa48/helio-oiticica. Acesso em: 22 abr. de 2014.

Disponível em: http://girocariocatour.blogspot.com.br/2013/10/centro-cultural-heliooiticica.html. Acesso em: 2 mar. 2017.
} 
Figura 12: Obra "Mother” em “Álbum de família"

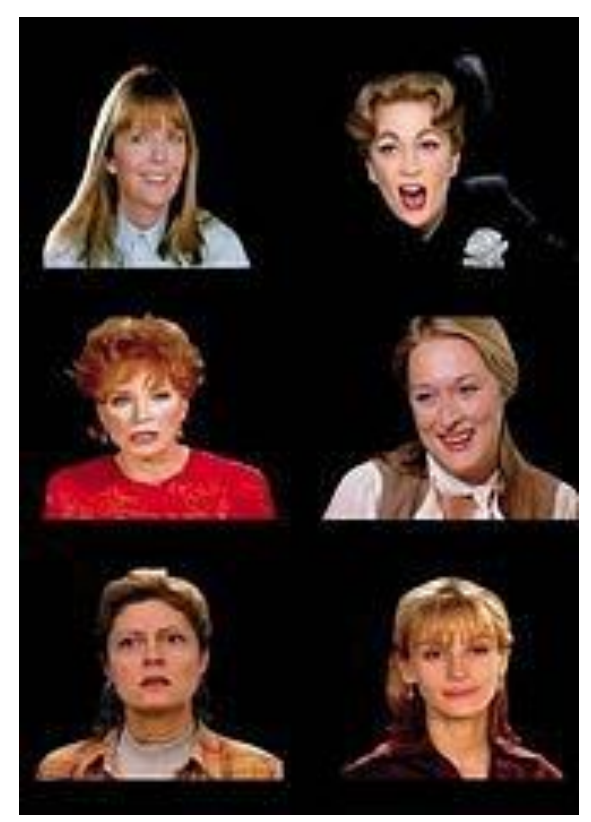

Fonte: Rioshow/Divulgação ${ }^{82}$

A visitação esteve disponível a partir de agosto de 2015 e apresentava ao público cerca de quarenta trabalhos de mais de vinte artistas brasileiros e estrangeiros, como Adriana Varejão, Anna Bella Geiger, Bill Viola, Candice Breitz, Charif Benhelima, Fábio Morais, Gillian Wearing, Jonathas de Andrade, Michel Journiac, Ricardo Basbaum, Rosângela Rennó, Santu Mofokeng, Tracey Rose, Victor Burgin e Zanele Muholi. Pinturas, objetos, fotografias, desenhos, videoinstalações, instalações sonoras e filmes, com curadoria de Daniella Géo, ocupavam todas as salas expositivas da instituição.

Geralmente, os alunos eram recebidos na escadaria do prédio e a conversa inicial era sobre o fato de o espaço ser público, gratuito e que poderiam voltar sempre que desejassem, com os familiares e amigos. Antes de iniciarem a visita, os mediadores ofereciam um tempo aos alunos para que fossem ao banheiro e bebessem água e também estabeleciam dois combinados: poderiam fotografar a exposição sem usar o flash e não poderiam tocar nas obras. Novamente, falar sobre o uso do celular partiu dos mediadores e, de modo geral, os alunos fizeram uso do aparelho em alguns momentos para os selfies e, também, como instrumento para registros que seriam utilizados em trabalhos escolares.

\footnotetext{
${ }^{82}$ Disponível em: http://rioshow.oglobo.globo.com/exposicoes/galerias/album-de-familia13622.aspx. Acesso em: 2 mar. 2017.
} 
Os alunos eram divididos em dois grupos e, durante todo o percurso, eram estimulados a falar sobre as impressões que tinham sobre as obras e os sentimentos despertados, a partir do contato com a exposição. Os mediadores buscavam deixar claro que não havia certo ou errado, que cada um poderia interpretar como quisesse, que o papel do museu não era o de ensinar. "Cada um de nós, combinando percepção, imaginação, repertório cultural e histórico, lê o mundo e o reapresenta à sua maneira, sob o seu ponto de vista, utilizando formas, cores, sons, movimentos, ritmo, cenário..." (MARTINS, M. et al, 1998, p.57).

Cabe ressaltar que durante o período em que as escolas faziam o circuito pelos sete equipamentos culturais, a exposição “Álbum de família” foi encerrada, já que era temporária. Em uma das observações realizadas, como alternativa, o percurso oferecido foi um passeio nos arredores do CMAHO, especialmente na Praça Tiradentes - local próximo à instituição. Os alunos e docentes foram informados sobre uma nova exposição que estava sendo montada e seria inaugurada naquele final de semana, recebendo o convite e as explicações dos mediadores: primeiro haveria uma festa na Praça Tiradentes e, depois, a inauguração.

\section{D) Espaço OI Futuro - Museu das Telecomunicações}

No prédio situado na zona sul da cidade já funcionou a Estação Telefônica Beira-Mar, inaugurada em 1918. Posteriormente, durante muitos anos, abrigou o Museu do telefone e, desde 2005, foi aberto ao público o Espaço Oi Futuro e o Museu das telecomunicações (figura 13). Segundo o site ${ }^{83}$ da instituição,

Com curadorias próprias, o Oi Futuro aposta no fomento e na disseminação de novas linguagens artísticas. O centro cultural dispõe de condições técnicas que possibilitam a constante experimentação, potencializando a convergência entre a arte, a ciência e a tecnologia. A própria arquitetura, com galerias expositivas flexíveis e um teatro multiuso, admite várias configurações palco-plateia, estimula a investigação artística e a interação dos visitantes com o espaço.

Em 2015, enquanto os alunos participavam do circuito proposto pelo Projeto Escola e Museu, o Espaço Oi Futuro abrigou a exposição temporária de artes visuais "Quase aqui”, de Daniel Senise ${ }^{84}$. A exposição contou com curadoria

\footnotetext{
83 Disponível em: http://www.oifuturo.org.br/cultura/oi-futuro-flamengo/. Acesso em: 2 mar. 2017.

${ }^{84}$ Daniel Senise se formou em engenharia civil na UFRJ em 1980 e, no ano seguinte, ingressou na Escola de Artes Visuais do Parque Lage, onde participou de cursos livres até 1983. Em 1985,
} 
de Alberto Saraiva e Flávia Corpas e entrou em cartaz em agosto, ocupando quatro ambientes da instituição. A amostra de Senise fez parte da Programação especial em comemoração aos dez anos do Espaço OI Futuro Flamengo.

Figura 13: Espaço Oi Futuro - Flamengo

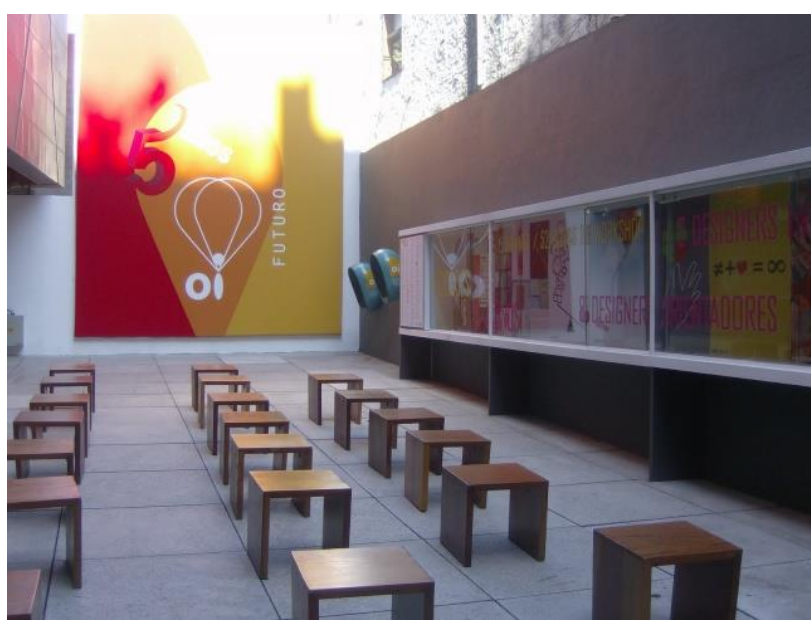

Fonte: Rio no Tetro/Divulgação ${ }^{85}$

Daniel Senise é um dos principais artistas visuais do Brasil e desenvolveu obras que se comunicavam e interagiam com a arquitetura do Espaço Oi Futuro. A parte da exposição denominada "Biblio-Tec" estava no primeiro nível do Oi Futuro e trazia um grande painel feito com fita isolante sobre o vidro dos fundos, filtrando a parte da luz externa. Em seguida, estavam expostas quatro antigas mesas de trabalho do artista com as marcas do tempo visíveis na madeira.

A segunda galeria era uma homenagem ao alemão Caspar David Friedrich, um dos principais nomes do romantismo no século XIX. A

tornou-se professor. O artista participa de diversas mostras coletivas, como as Bienais de São Paulo, La Habana, em Cuba, Veneza, Liverpool, Cuenca e tem obras expostas no MOMA, em Nova York, no MASP e no MAM de São Paulo, no Musee d'Art Moderne de la Ville, em Paris, no Museu Ludwig, na Alemanha e outros. Além disso, expõe suas obras individualmente em galerias e museus nacionais e internacionais. MAC de Niterói, Museum of Contemporary Art de Chicago, Museo de Arte Contemporáneo (México), Pulitzer Art Galery (Amsterdam) e diversos outros fazem parte de seu currículo. Ao longo de quase três décadas, o artista vem trabalhado em obras dos mais variados tipos, como pinturas, fotografias, gravuras, maquetes, intervenções, impressões e até mesmo projetos desenvolvidos em ambientes virtuais. Durante a exposição "Quase Aqui”, Daniel Senise ampliará ainda mais esse trabalho de criação da imagem com dois site-specifics, que são obras que dialogam com o meio para o qual são elaboradas em lugares e momentos escolhidos pelo artista. "O espaço do Oi Futuro sugere esse movimento de confluências de linguagens e de superação das superfícies, que já vem do século 20: a pintura sai de sua área contida e ocupa o espaço", diz o artista visual. Disponível em: http://www.heloisatolipan.com.br/arte/o-artista-daniel-senise-transforma-a-arquitetura-do-espacocultural-oi-futuro-para-a-exposicao-quase-aqui/. Acesso em: 1 de março de 2017.

${ }^{85}$ Disponível em: http://www.rionoteatro.com.br/localeventos/view/31. Acesso em: 2 mar. 2017. 
instalação "Caminhante" (figura 14) fazia referência à "Der Wanderer über dem Nebelmeer" (Caminhante sobre o mar de névoa), uma das mais conhecidas pinturas do artista. Para abrigar a exposição, a sala foi desconstruída e os visitantes podiam perceber as paredes originais da Estação Telefônica Beira-Mar, de 1918, que estavam anteriormente ocultas pelo gesso do prédio.

Figura 14: Instalação "Caminhante” de Daniel Senise em "Quase aqui".

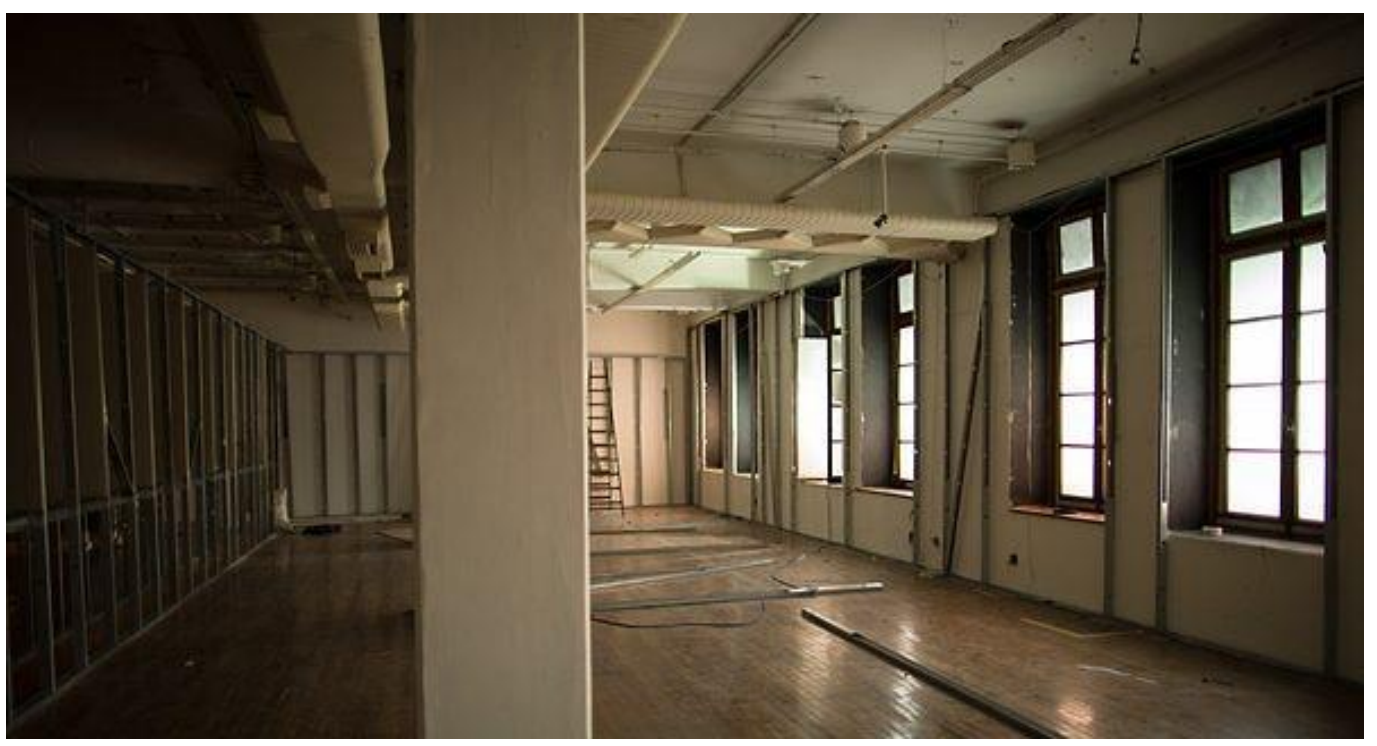

Fonte: Rioshow/Divulgação ${ }^{86}$

A terceira parte da exposição recebia cinco pessoas por vez. Na parede do fundo, havia uma fotografia pequena que retratava o espaço em que Daniel Senise vivera a sua infância. "Mundial", o nome da obra, fazia referência à rádio que tocava Projetoção jovem nos anos 70.

Além da exposição temporária, os alunos tinham contato com o acervo da exposição permanente do Museu das Telecomunicações. O site ${ }^{87}$ da instituição informa que

O Museu das Telecomunicações do Oi Futuro é um espaço para vivenciar a interatividade. Viajar pela aventura da comunicação humana, com olhos abertos para o passado, para o presente e para o futuro. Inspirado no conceito de hipertexto, as camadas de informação são reveladas aos poucos, em um formato lúdico e interativo, pioneiro no Brasil. Dessa forma, cada visitante pode viver uma experiência diferente, descobrindo os conteúdos no seu próprio tempo e

\footnotetext{
${ }^{86}$ Disponível em: http://rioshow.oglobo.globo.com/exposicoes/galerias/daniel-senise-quase-aqui13895.aspx. Acesso em 2 mar. 2017.

${ }^{87}$ Disponível em: http://www.oifuturo.org.br/cultura/museu-das-telecomunicacoes/. Acesso em: 1 mar. 2017.
} 
respeitando sua própria curiosidade. Visitar o museu é uma viagem surpreendente e divertida pela história da comunicação no Brasil e no mundo.

O museu conta com um Projeto Educativo ${ }^{88}$ que propõe uma viagem pela história da comunicação humana, tendo como meio vivências compartilhadas através de visitas mediadas que buscam

a formação de um olhar sensibilizado, atualizado, crítico e reflexivo sobre os mais variados conceitos da arte e tecnologia. Isso porque o Projeto oferece diversas atividades para atender à curiosidade e ao interesse de variados públicos. A ideia é explorar esse universo da comunicação e da tecnologia de forma participativa.

Durante as visitas, os alunos e docentes eram recebidos em dois ambientes distintos, dependendo dos mediadores - pátio externo do museu ou no saguão -, que abordavam, a partir da experiência dos alunos, os conceitos de tecnologia e comunicação. Em seguida, após o acolhimento e conversa inicial, o grupo era dividido e faziam o percurso nos diferentes andares do museu. Um grupo começava o percurso pela exposição temporária e o outro pela exposição permanente.

Quando os alunos e docentes chegavam ao Museu das Telecomunicações, recebiam um fone de ouvido e um aparelho denominado pick-up que, ao ser apontado para algum item do acervo, proporcionava acesso a um áudio-guia, conduzindo os alunos por uma viagem pelo tempo através da história da comunicação. Ao longo da visita, eram estimulados a construir o seu próprio tempo e a interagir com os objetos, conhecendo a tecnologia da comunicação e o seu desenvolvimento nos diferentes períodos. Nesse sentido, Hermann (2010, p. 54) afirma que "a experiência estética nos permitiria superar a imediatez de um mero encantamento, em que estaríamos jogados na descontinuidade e na pontualidade da vivência, pois ela responde à realidade histórica, a algo que nos ultrapassa."

Durante a última observação realizada nesse espaço, um dos mediadores desenvolveu uma atividade nova com os alunos sobre a exposição temporária. $\mathrm{Na}$ sala que abrigava a instalação "Caminhante", a mediadora comparou as características da obra com a que haviam visto anteriormente (a obra "Mundial"). Contou que trabalhava no Espaço Oi Futuro Flamengo desde 2008 e nunca havia

\footnotetext{
${ }^{88}$ Disponível em: http://museudastelecomunicacoes.org.br/Projeto-educativo/. Acesso em: 1 mar. 2017.
} 
visto as janelas daquela sala, mas que o artista havia retirado as paredes que as escondiam. Em seguida, entregou diferentes matérias para representarem o espaço: quatro tipos de papéis (branco, reciclado, quadriculado e manteiga), fitas, tesouras, lápis e canetas. A mediadora, formada em artes, relatou que começou essa atividade com os profissionais do Departamento Geral de Ações SócioEducativas (DEGASE) e incorporou a outros grupos porque percebeu que os alunos tinham dificuldade em observar e entender a obra "Caminhante". Com essa atividade acreditava que os alunos se acalmavam e se concentravam na observação.

\section{E) Fundação Eva Klabin}

A Fundação Eva Klabin, localizada na zona sul da cidade, abriga a coleção, em exposição permanente e aberta ao público na casa-museu, reunida por Eva Klabin ${ }^{89}$, que dedicou sua vida a colecionar obras de arte, configurando-se como um dos mais importantes acervos de arte clássica do Brasil, indo do Egito Antigo ao Impressionismo, ou seja, quase 50 séculos retratados em pinturas, esculturas, mobiliário e objetos de arte decorativa.

O espaço também acolhe exposições temporárias, como durante parte do tempo em que os alunos participantes do Projeto Escola e Museu faziam o circuito, que a Fundação Eva Klabin (figura 15) abrigou a exposição temporária intitulada "A presença da ausência" (figura 16), de Eduardo Berliner e curadoria de Marcio Doctors. Berliner foi o primeiro pintor a participar como convidado do Projeto Respiração ${ }^{90}$. Como a Fundação Eva Klabin é uma casa-museu, cujas paredes são repletas de coleções, a proposta desenvolvida para a exposição

\footnotetext{
${ }^{89}$ Nascida em São Paulo (1903-1991), era a primeira filha dos imigrantes lituanos Fanny e Hessel Klabin, que ainda tiveram Ema e Mina. Seu pai, juntamente com os irmãos, foi um dos fundadores das indústrias de papel e celulose Klabin. Anfitriã requintada, fez de sua casa e coleção o cenário ideal para recepcionar personalidades de grande expressão nacional e internacional, entre as quais o ex-presidente Juscelino Kubitschek, o israelense Shimon Peres e os norte-americanos David Rockfeller e Henry Kissinger, ex-secretário de Estado. Amiga de Burle Marx, suas festas eram conhecidas pela sofisticação, principalmente dos arranjos florais, especialmente criados em sua homenagem, pelo amigo paisagista. Disponível em: http://www.evaklabin.org.br/fundacao_colecionadora.aspx?sec=1\&id=75. Acesso em: 22 abr. 2017.

90 Criado em 2004, o Projeto Respiração tem por objetivo criar intervenções de arte contemporânea no acervo de arte clássica da Fundação Eva Klabin. Com curadoria de Marcio Doctors, o projeto consiste em convidar artistas contemporâneos a intervirem no circuito expositivo da casa museu, criando uma ponte entre a arte consagrada do passado e as manifestações contemporâneas.
} 
temporária foi através de instalações. A exposição ficou aberta ao público entre setembro de 2015 e janeiro de 2016.

Figura 15: Fundação Eva Klabin

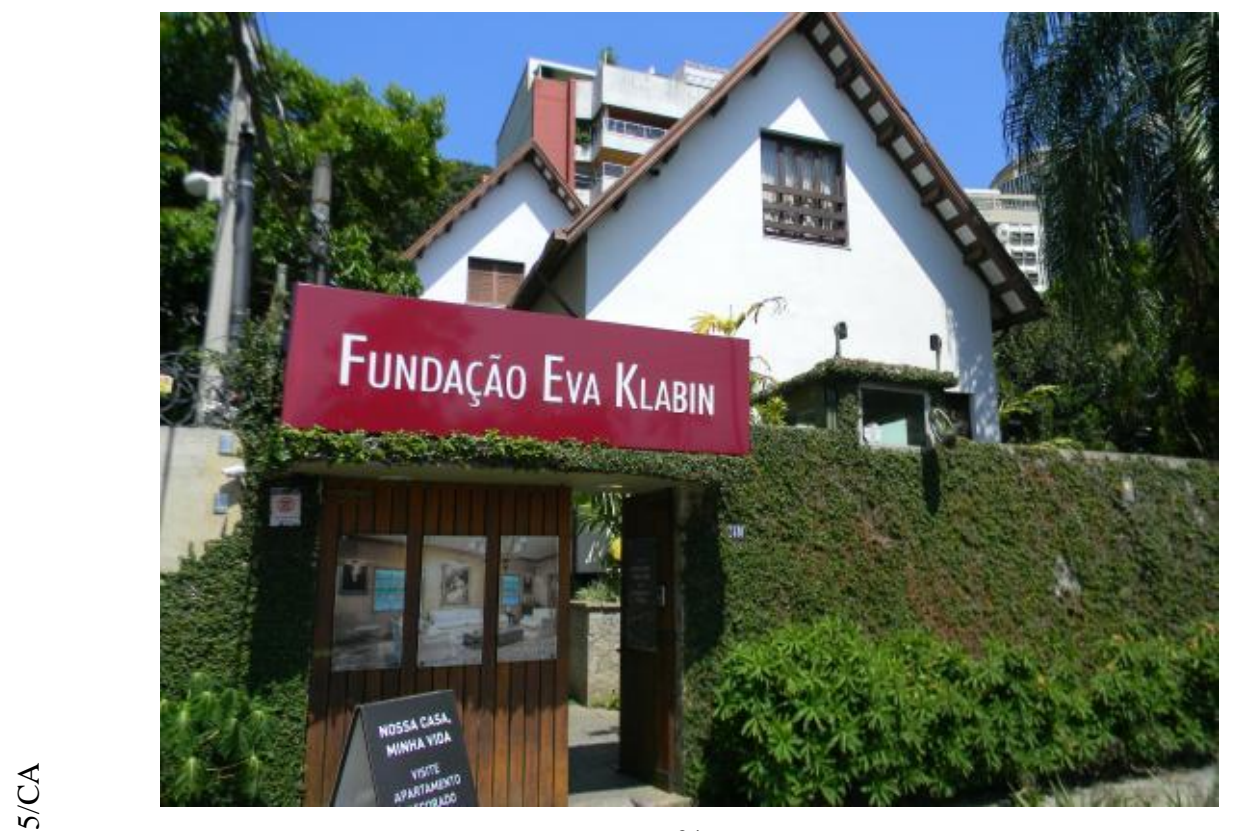

Fonte: Tripadvisor/Divulgação ${ }^{91}$

Na Fundação Eva Klabin, os alunos e docentes eram recebidos na área externa da casa-museu, onde era servida água gelada. Depois, eram encaminhados ao hall principal e posicionados em uma roda. Os mediadores distribuíam sapatilhas, conversavam sobre cultura e arte e estabeleciam os combinados como, por exemplo, não poder tocar nos objetos e nem sentar no mobiliário. A questão do uso do celular também apareceu de modo mais evidente nesta instituição. Os mediadores explicavam que liberariam os registros fotográficos em alguns momentos e, com isso, os alunos não faziam expressões de insatisfação e, de fato, não aparentavam mexer no celular, exceto nas situações em que era autorizado o uso.

Mediador: Você (nome da professora), pode fotografar o tempo inteiro. É interessante que fotografe tudo, as dinâmicas. Vocês (se dirigindo aos alunos), lembrando, celular no bolso, em determinados momentos a gente vai falar, agora pode fotografar, agora pode. Tudo bem?

\footnotetext{
${ }^{91}$ Disponível em: https://www.tripadvisor.com.br/LocationPhotoDirectLink-g303506-d2352217i120557678-Fundacao_Eva_Klabin-Rio_de_Janeiro_State_of_Rio_de_Janeiro.html. Acesso em: 2 mar. 2017.
} 
Figura 16: Instalação de Eduardo Berliner em "A presença da ausência"

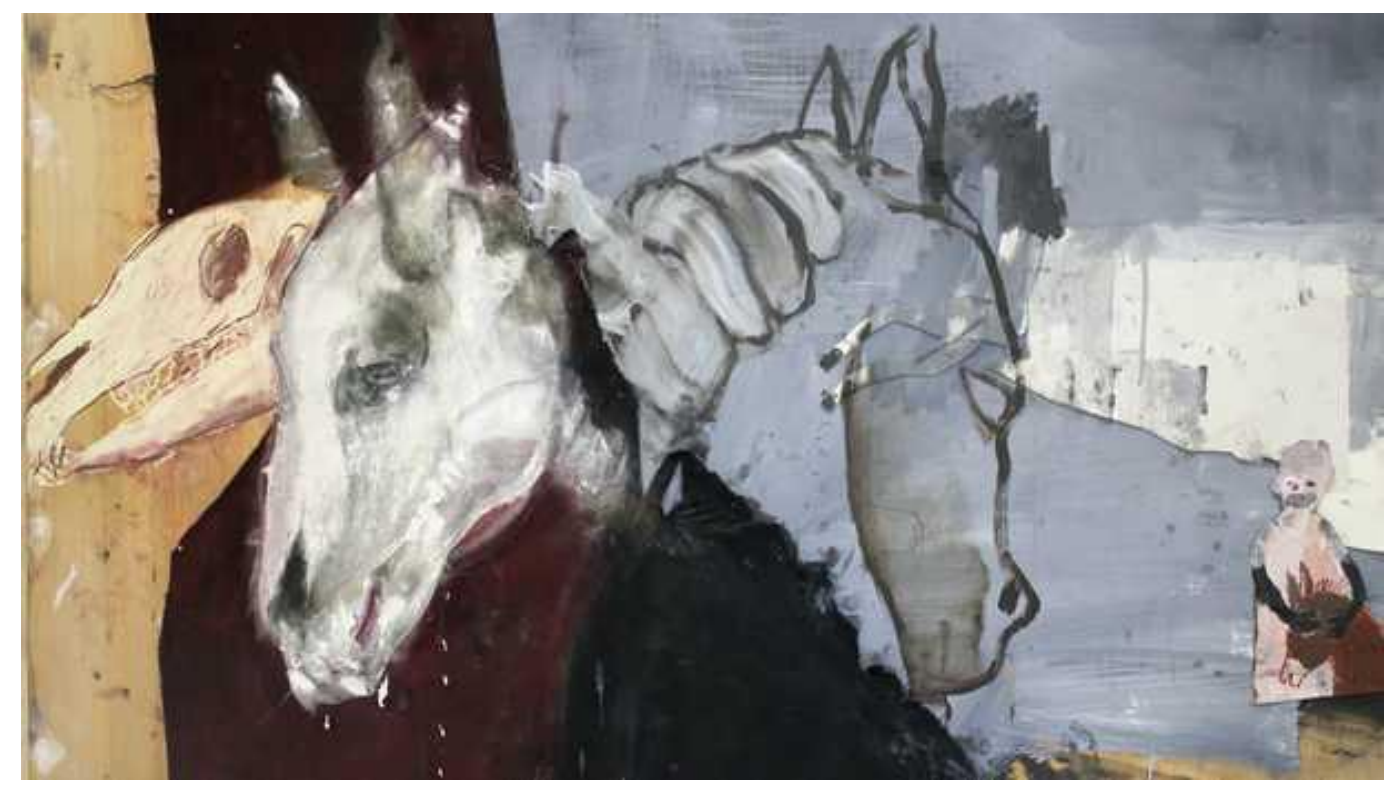

Fonte: Fundação Eva Klabin/Divulgação ${ }^{92}$.

Antes de iniciar o percurso pelas dependências da casa-museu, os alunos eram divididos em dois grupos e convidados a brincar de observar a casa e, no caso de dúvida ou algum comentário sobre um determinado objeto, não apontar para ele, mas sim descrevê-lo e a turma deveria tentar adivinhar qual objeto estava em questão. Em seguida, os mediadores complementavam com informações acerca da obra de arte que havia atraído os alunos, contavam histórias sobre a aquisição da peça e sobre o ambiente. Além disso, os alunos faziam outras observações sobre o que viam e ouviam, havendo forte ligação entre os sujeitos e as obras e entre os sujeitos.

Essa estratégia utilizada pelos mediadores apresenta forte ligação com a ideia de formação cultural pensada por Gadamer (2005) através da noção de jogo como modo de ser da obra de arte, ou seja, a obra de arte joga com o seu expectador e o desafia.

Se a arte não é a variedade de vivências cambiantes, cujo objeto é preenchido cada vez com significado subjetivo como se fosse fórmula vazia, a "representação" terá de ser reconhecida como o modo de ser da própria obra de arte. Isso deveria ser preparado derivando o conceito de representação do conceito de jogo, na medida em que o representar-se é a verdadeira essência do jogo - e com isso também a obra de arte. Através de sua representação, o jogo jogado interpela o espectador e de tal modo que este passa a ser parte integrante do objeto, apesar de todo o

\footnotetext{
${ }^{92}$ Disponível em: http://www.evaklabin.org.br/respiracao_detalhes.aspx?sec=5\&id=573. Acesso em 2 mar. 2017.
} 
distanciamento do estar de frente para o espetáculo. (GADAMER, 2005, p.171172).

Nessa perspectiva de jogo, o aluno pode experimentar uma autonomia na qual é possível acontecer uma interação comunicativa a ponto de incorporar uma nova linguagem, um novo aprendizado, no sentido mais belo do termo, ou seja, a dimensão de algo se oculta e passa a fazer parte intrínseca do corpo.

F) Museu de Arte do Rio (MAR)

O MAR (figura 17) foi inaugurado em 2013, no centro da cidade, e funciona como um espaço de apoio à educação, trabalhando em parceria com a SME/RJ e outras secretarias de Educação. O museu também tem como missão o registro da arte no ensino público, por meio da Escola do Olhar, que desenvolve um Projeto acadêmico, construído em coparticipação com universidades, para discutir arte, cultura da imagem, educação e práticas curatoriais, tendo como foco principal oportunizar experiências na formação de docentes da rede pública.

Figura 17: Museu de Arte do Rio

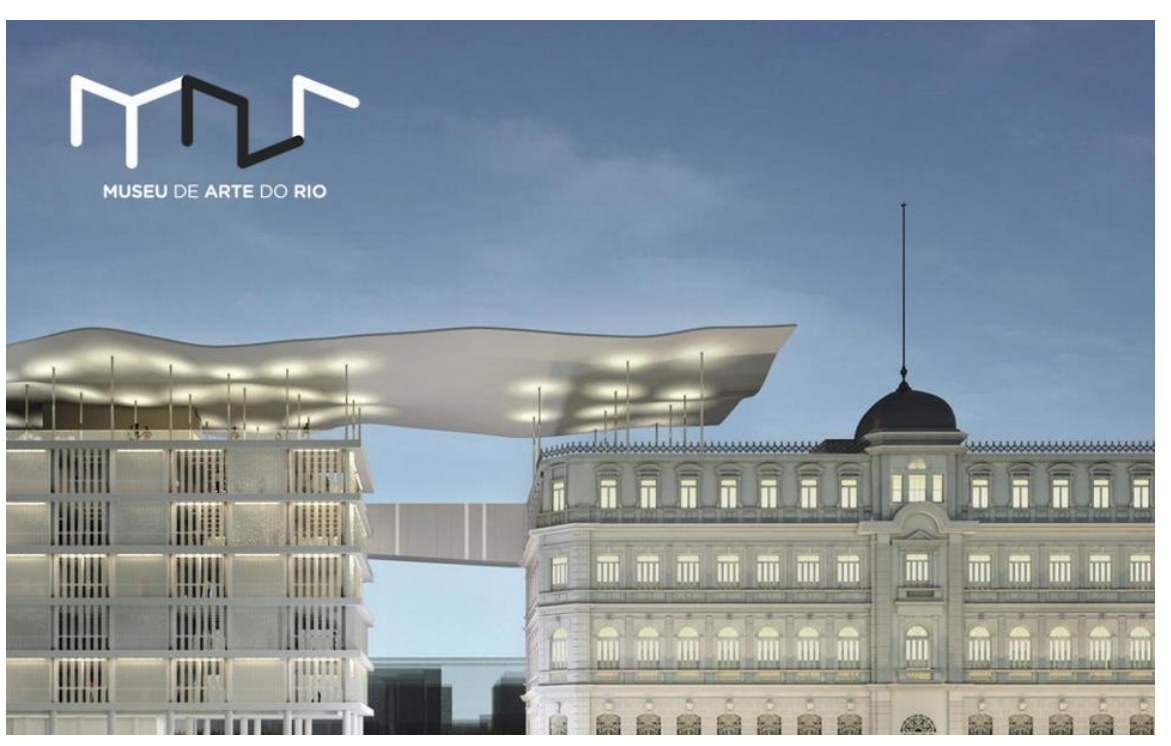

Fonte: Helena Mattos ${ }^{93}$

Esse espaço abriga a sua própria coleção e conta também com empréstimos de obras de algumas coleções públicas e privadas do Brasil.

\footnotetext{
${ }^{93}$ Disponível em: http://helenamattos.com/2016/09/domingo-no-mar-museu-de-arte-do-rio/. Acesso em: 2 mar. 2017.
} 
Infelizmente, demorou muito a autorização para adentrar esse espaço, o que inviabilizou a observação. Quando surgiu a oportunidade de ver o percurso e as práticas trabalhadas com os alunos, ao ligar para confirmar a observação da visita, fui informada que a mesma não aconteceria porque o ônibus havia sido cancelado, impossibilitando o deslocamento dos alunos.

\section{G) Museu Nacional/UFRJ}

O Museu Nacional/UFRJ (figura 18) é o maior museu de história natural e antropológica da América Latina, criado por D. João VI em 1818, localizado em um bairro da zona central do Rio de Janeiro. Anteriormente, era conhecido por Museu Real e foi incorporado à Universidade do Brasil em 1946.

Figura 18: Museu Nacional/UFRJ

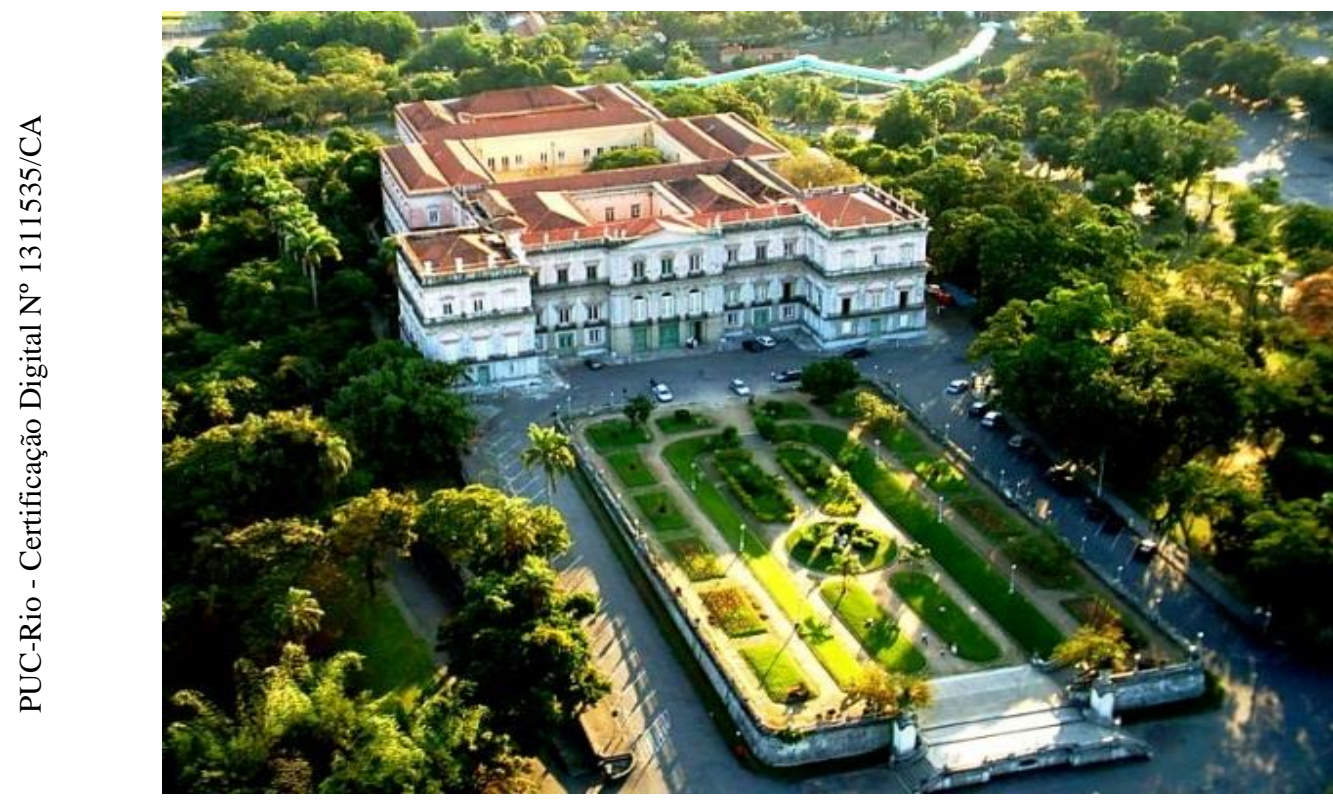

Fonte: Museus do Rio/Divulgação ${ }^{94}$

Os alunos e decentes participantes do Projeto Escola e Museu eram convidados a refletir sobre "De onde viemos?" (figura 19), uma proposta de visita ao Museu Nacional. O percurso era realizado pelas dependências do museu obedecendo a seguinte ordem: Hall (meteorito de Bendegó), Paleontologia,

\footnotetext{
${ }^{94}$ Disponível em: http://www.museusdorio.com.br/joomla/index.php?option=com_k2\&view=item\&id=12:museunacional. Acesso em 2 mar. 2017.
} 
Evolução humana, Egito, Culturas Mediterrâneas, Culturas Pré-Colombianas, Luzia, Sambaquis, Cerâmica, Etnologia indígena (contempla a maioria das salas com exposições permanentes, porém não abrange as exposições temporárias). Assim, os alunos poderiam refletir sobre os eventos que ocorreram ao longo de bilhões de anos e que nos possibilitaram chegar ao atual estágio de evolução, bem como sobre a longa busca do ser humano pelas suas origens.

A partir dessa proposta, os mediadores propunham uma reflexão sobre o local em que a escola estava situada e o que representava o espaço que estavam visitando. Em seguida, iniciava-se o percurso pelo museu tentando retratar a origem da vida e a evolução no planeta Terra, perfazendo uma trajetória com cunho científico e cultural, momento em que os mediadores faziam a abordagem da evolução humana.

Apesar de informarem no roteiro que o tempo médio de visitação era de 1h30, em todas as observações realizadas, o tempo foi excedido e o final do trajeto ficava prejudicado, com informações apresentadas de modo aligeirado e sem muito espaço para questionamentos. Na maior parte das observações, os alunos ficavam mais envolvidos a partir do meio do roteiro, onde viam as múmias, sarcófagos e buscavam informações sobre evolução humana e história das civilizações. Cabe ressaltar que, no período das observações, estava sendo veiculada a telenovela brasileira "Os dez mandamentos" por um canal da TV Aberta. A primeira temporada foi exibida entre março e novembro de 2015 e relatava a história do personagem bíblico Moises, retratando diversos aspectos da cultura egípcia e hebreia, o que suscitava a curiosidade dos alunos e o desejo de fazer registros fotográficos.

Mediadora: Vou dar dois minutinhos para tirarem fotos. Somos o museu com a maior coleção de egiptologia da América Latina. Vou contar essa sala de duas formas: a história da coleção e os ritos. (Nesse momento, os alunos ficam atentos e começaram a fazer diversas perguntas). (Trecho do caderno de campo, 2015 MN/UFRJ)

No entanto, faltava tempo para explorar mais os setores do trajeto que abordavam essa temática, por estarem localizados na parte final do percurso. Segundo Marandino (2001, p. 96),

a relação estabelecida entre os sujeitos e o conhecimento em espaços como este pode ser considerada diferente da escola: trata-se de um outro tempo - o intervalo de tempo de interação com o conhecimento e o ritmo em que ocorre é diferenciado - de um outro espaço físico e de uma outra forma organização do saber científico. 
Figura 19: Meteorito de Bendegó

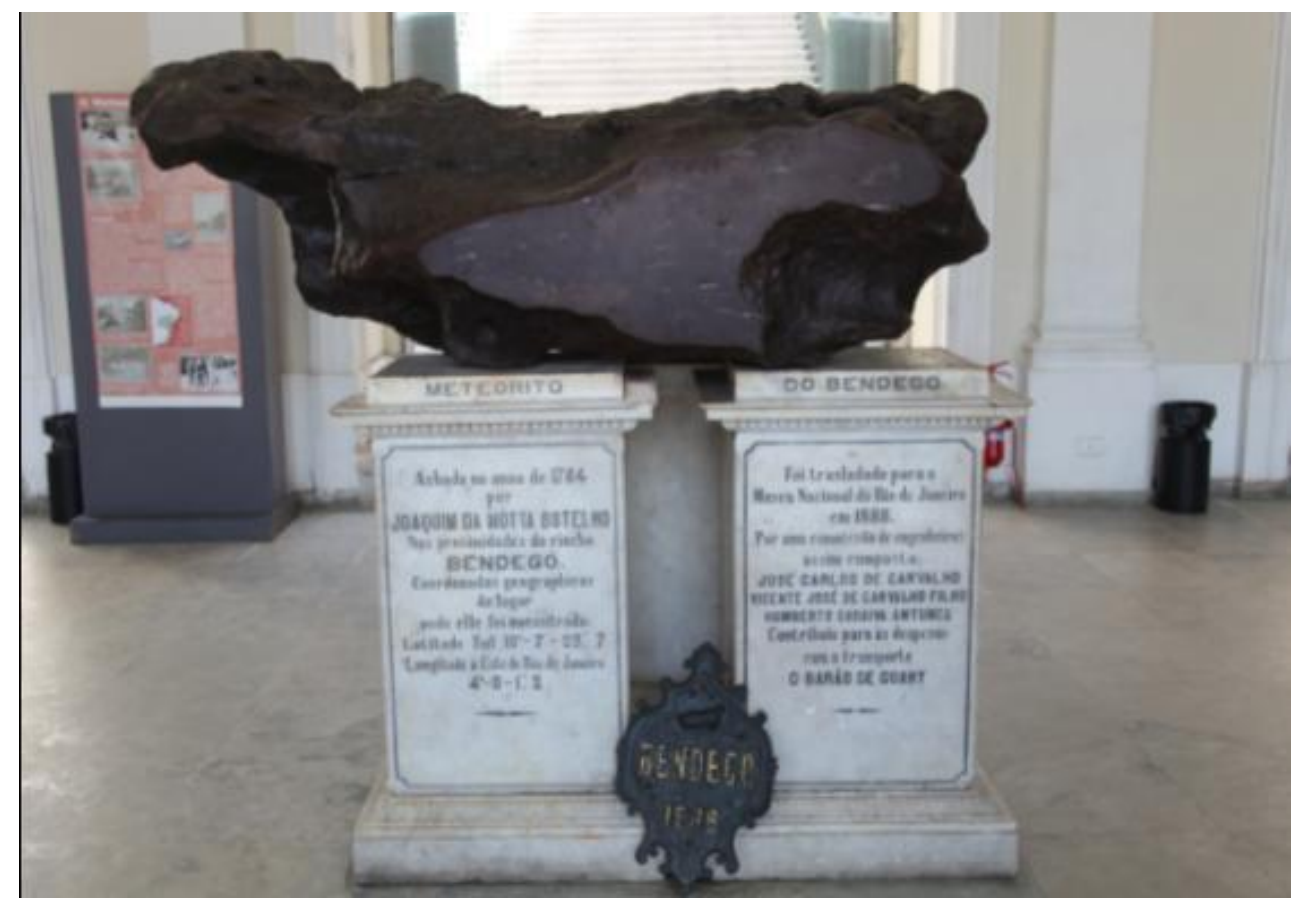

Fonte: Museu Nacional/Divulgação ${ }^{95}$.

Tendo então apresentado os equipamentos culturais investigados nesta pesquisa, com uma breve síntese de suas exposições e da rotina de acolhimento dos grupos, exponho agora as leituras, apropriações e reinterpretações da política realizadas por cada instituição participante do Projeto Escola e Museu. Como discutido anteriormente, a política existe não apenas no texto, mas na prática e, cada instituição, fez a sua implementação da proposta.

Em todos os roteiros disponibilizados pelos espaços, o responsável pelo setor educativo deveria delegar, ao longo do circuito interativo, uma equipe para acompanhar os alunos das escolas municipais participantes do Projeto. No entanto, conforme sinalizado anteriormente, no momento de efetivação da pesquisa, uma das instituições - CCBB -, acolhia uma megaexposição - Picasso recebendo um elevadíssimo contingente de público, realizando apenas o acolhimento das escolas e uma conversa inicial. Após esse momento introdutório, o mediador deixava alunos e professores na porta de entrada da exposição e não

\footnotetext{
95 Disponível em: https://saemuseunacional.wordpress.com/de-onde-viemos/\#jp-carousel-907. Acesso em: 2 mar. 2017.
} 
prosseguia nenhum percurso com o grupo. Kramer e Carvalho (2012) apontam a relevância do papel do mediador e destacam que a

educação em museus precisa se configurar como convite, visita e mediação. Convidar crianças e jovens significa ir junto. Visitar as obras, os autores, viver com arte e história. Mediar para que crianças, jovens e adultos possam ser narradores da história. (p. 27).

O cuidado com a mediação é algo basilar, pois pode levar tanto os alunos quanto os docentes a vivências excelentes, despertando o desejo de tornarem-se audiência espontânea, ou, por outro lado, confirmar um imaginário de que o museu é apenas para uma elite. João Teixeira Lopes (2005) afirma que

o Museu é, antes de mais, uma instância de mediação: entre objetos e pessoas; entre profissionais e públicos; entre criadores e modos de circulação e apropriação das suas obras; entre os poderes oficiais e as visões contra-hegemônicas; entre modelos organizacionais e lógicas vivenciais e mundanas. Basta pensar na complexidade do campo profissional que rodeia hoje o museu para nos apercebermos de que os recursos que mobiliza pressupõem uma ampla negociação de significados. (p. 198).

Quando indaguei os docentes sobre a percepção da mediação realizada pelo setor educativo do CCBB, alguns apontaram tal situação como algo negativo, como pode ser observado nos trechos das entrevistas abaixo.

Docente 9: É, durante eu senti, até eu mesmo fiquei meio perdido, porque quando eu vim na capacitação, a gente ia fazer outra visita que era a história do Banco do Brasil, o teatro..., não ia ser do Picasso, como estava tendo Picasso eles colocaram as escolas, então durante eu mesmo fiquei perdido, talvez os alunos também tenham ficado.

Docente 18: O que eles fizeram foi mais uma apresentação do que os alunos iriam encontrar aqui (na exposição), mas eles me pareceram mais preocupados em definir regras - isso pode, isso não pode - do que de fato explicar sobre a exposição aos alunos.

Docente 14: Hoje, a dinâmica ali eu gostei (referindo-se à conversa inicial sobre a exposição), deu para a gente entender, talvez se a gente fosse à exposição ia ficar uma coisa muito vaga, não ia entender o que estava sendo visto ali, acho que deu para a gente entender, como o que a gente ia ver na exposição.

Docente 3: No início (referindo-se à conversa inicial sobre a exposição), quando teve mediação foi legal, quando não teve, ficou ruim, mas o ruim porque teve o contato com outras escolas, o que dispersa um pouco os alunos, não só os meus, como os de outras escolas também dispersa, fica um zum zum zum complicado de você está explicando alguma coisa e fica um pouco, como é que eu posso falar? Fica meio sem norte, você fica meio desnorteado, vai para aqui, vai para ali, e infelizmente adolescente ele é muito prático, ele tem que ter uma linha que ele siga, tem que ter uma seta, se ele não tiver aquela seta que ele siga, ele fica muito disperso, e adolescente disperso não funciona nada. Você pode fazer malabarismo 
que ele não vai te ver! Então, o ruim de hoje foi que, infelizmente não teve uma mediação com o grupo, dentro da exposição Picasso, alguém que pudesse chegar, deixar a gente mais coeso e manter. E falar é isso, é aquilo, dar uma explicação geral.

Antes de discutir o contexto da prática do Programa Escola e Museu no âmbito das instituições, cabe um comentário sobre a concepção de juventude presente na fala do docente 3 e que é frequente na sociedade de modo geral. Segundo Dayrell e Gomes (2009, p. 1),

a juventude brasileira ainda não é encarada como sujeito de direitos, não sendo foco de políticas públicas que garantam o acesso a bens materiais e culturais, além de espaços e tempos onde possam vivenciar plenamente esta fase tão importante da vida. Além disso, (...) o jovem não é levado a sério, exprimindo a tendência, muito comum nas escolas e programas educativos, de não considerar o jovem como interlocutor válido, capaz de emitir opiniões e interferir nas propostas que lhes dizem respeito, desestimulando a sua participação e o seu protagonismo.

Uma mediadora foi questionada sobre a razão de não fazerem a mediação com os alunos do Projeto Escola e Museu e a mesma respondeu que a mediação "agarra" o ritmo, prende o fluxo.

Porém, alguns docentes acharam interessante a ideia de deixarem os alunos com mais liberdade para se apropriarem da exposição.

Docente 18: No CCBB nós fomos recebidos, ele (o mediador) deu uma pequena ideia do que era o Picasso, os principais temas dele, o que significou o cubismo na história da arte e deixou a gente livre para explorar a exposição. Também é um tipo legal. Gostei dessa liberdade, eu deixei eles livres, assim, sempre do lado para tentar tirar dúvidas, mas também achei legal.

Ainda com relação à mediação realizada nos espaços parceiros da SME/RJ, em outro equipamento cultural, O Museu Nacional da UFRJ, a mediadora selecionada para fazer o roteiro com os alunos estava com problema nas cordas vocais e não poderia fazer o atendimento junto aos alunos. $\mathrm{O}$ percurso interativo foi então realizado por uma aluna de graduação em Ciências Sociais. Por mais que ela tentasse conduzir de modo proveitoso a atividade, em alguns momentos, eram nítidas as lacunas quanto aos conhecimentos biológicos, especialmente, os evolutivos específicos da área, como fica evidente na fala de um dos docentes:

Docente 12: Eu achei que colocaram a menina numa situação muito complicada..., já que ela não tinha formação para explicar as coisas que estava explicando, não foi proposital, ela até se esforçou e tal, mas ela mesma disse que era de ciências sociais explicando tópicos de biologia. Sem condição. 
Por mais que o intuito do Projeto não seja a escolarização do museu, não é possível também aceitar como algo natural a transmissão de informações errôneas. Apesar da mediadora em questão não ser habilitada em ciências biológicas, caberia ao setor educativo fazer a formação necessária para que essa estudante tivesse segurança e conhecimento necessários para conduzir a atividade proposta ou, caso a formação já tivesse sido concluída e não houvesse segurança para a condução do percurso, que outra pessoa fosse designada para a atividade. Vale destacar que, quando chegaram ao setor do Egito, a mediadora estava muito mais à vontade e, até mesmo, mais animada, falando em detalhes sobre cada uma das vitrines. Nesse momento, a qualidade da mediação ofertada melhorou muito.

Com relação à mediação realizada pela equipe da Fundação Eva Klabin, os depoimentos dos docentes apresentavam aspectos positivos, ressaltando o encontro que promoviam entre os alunos e a arte.

Docente 6: Achei muito bom, eles sabem, eu já tinha visitado a Eva Klabin antes, e eu percebi que eles conseguem traduzir a arte para a língua deles. Eles conseguem trazer a arte daquele pedestal que a gente acostuma colocar e que na verdade para mim não deveria estar, para o mundo deles, e fez com que eles conseguissem entender.

Um dos mecanismos encontrados para aproximar a arte e os alunos foi a referência à telenovela "Os dez mandamentos". Na sala de estar da casa-museu (Sala Renascença) havia uma enorme coleção de objetos do Egito e os mediadores fizeram uso desses recursos para alcançarem os alunos.

Mediador (FEK): Aqui, vocês estão assistindo os dez mandamentos? É legal, é uma novela bacana porque, apesar de ser uma emissora evangélica e por ser uma novela evangélica, mesmo querendo falar do evangelho, eles estão falando muito mais dos judeus, eles estão falando de toda a vida dos judeus. Desde a população daquela época, vocês já devem ter ouvido falar dessa deusa na novela...

Aluno: Qual?

Mediador (FEK): Sekhmet.

Aluno: É, é.

Mediador (FEK): Sekhmet é híbrida, é uma deusa que é metade mulher e a cabeça é de leoa, é a ideia da lenda, do mito. Na lenda você pode inventar um monte de coisa, assim como a fênix que é aquele pássaro que...

Aluna: Renasce das cinzas.

Mediador (FEK): Renasce das cinzas. Ali em cima a gente tem a figura de uma outra deusa. Já ouviu falar de Bastet?

Aluna: Bastet.

Mediador (FEK): Bastet é a deusa do amor, da harmonia, Sekhmet é a deusa da guerra, elas são opostas, mas elas também se complementam, exatamente porque uma está do lado da guerra e a outra está do lado do amor. (Trecho do caderno de campo, 2015 - FEK) 
A capacidade de aproximação da linguagem e do cotidiano dos alunos, bem como o domínio da exposição também foram aspectos considerados positivos pelos docentes quando questionados sobre as mediações realizadas no Espaço Oi Futuro e CMAHO. Teixeira Coelho (2004, p. 248) conceitua a mediação como "processos de diferente natureza cuja meta é promover a aproximação entre indivíduos ou coletividades e obras de cultura e arte". A perspectiva defendida nesta tese é que a forma como a mediação é realizada pode viabilizar o gosto pelo encontro entre os sujeitos e a arte ou afastá-los dos espaços de educação não formal.

Docente 20: Aqui no Oi Futuro eu acho que foi interessante, foi bacana. Eu acho que as monitoras atingiram o objetivo, elas integraram os alunos, até nos professores participamos das atividades, e foi bem esclarecedoras, eu acho que foi bem.

Docente 4: Muito boa (falando sobre a mediação). As meninas que estão fazendo esse trabalho conhecem bem, já tem fundamento suficiente para acompanhar as crianças e os adolescentes e até adultos também. Conhecem o espaço todo como parte de suas casas, digamos assim. Isso é muito importante para a pessoa que está fazendo a mediação.

Docente 16: Interessante, gostei muito porque ela chamou muito os alunos para pensarem. Não era aquela coisa pronta, ela até falou das questões que estão escritas, mas não é nada que está esclarecendo totalmente a obra. Então, eu achei legal que ela levantou os questionamentos, a curiosidade, gostei muito mesmo.

Outro aspecto relevante durante o percurso cultural nos sete equipamentos culturais foi a questão do horário para início das atividades também era algo estabelecido e enviado pelo setor de Extensividade da SME/RJ. As escolas recebiam um roteiro com os dias, horários e locais de visitação. Pela manhã, as visitas eram realizadas às $10 \mathrm{~h}$ e, no período da tarde, as atividades eram iniciadas às 14h. No entanto, por diversas razões como, por exemplo, engarrafamento, longos deslocamentos, atraso do ônibus, nem sempre os horários estabelecidos se efetivavam, gerando desconforto e ansiedade nos alunos como pode ser observado na fala abaixo.

Aluno: Moça, fala que é você que vai fazer o passeio com a gente! (reação ao ver a pesquisadora chegar ao CMAHO)

Pesquisadora: Não sou eu.

Aluno: Estamos aqui esperando há muito tempo. Chegamos bem cedo. (Trecho do caderno de campo, 2015 - CMAHO)

Numa das visitas observadas no Espaço Oi Futuro (Flamengo), os alunos aguardaram até às $14 \mathrm{~h} 15$ e, enquanto isso, vários estudantes ficaram mexendo nos 
telefones públicos. Quando os mediadores chegaram, avisaram que poderiam sentar no hall de entrada, ouvir música, ir ao banheiro e beber água. Com isso, a atividade só começou às $14 \mathrm{~h} 30$ e o início da conversa foi com a seguinte frase do mediador: Vocês estão só no celular! Maior vício!

A pressão do horário de retorno em função dos grandes deslocamentos e possibilidade de enfrentar longos engarrafamentos também se configurava como um problema na apreciação das exposições.

Aluna: Tanta pressa! Dá tempo de ver nada também! Professor, da próxima vez leva a gente ao cinema. (Essa aluna desejava fazer a leitura das placas sobre as obras e pausa para fruição. Ao final, abordou a entrevistadora e fez várias perguntas sobre Guernica).

Aluna: Puxa, a gente nem viu tudo!

Pesquisadora: O que mais você queria ver?

Aluna: Um monte de coisas que a moça falou no início, mas não deu tempo de ver...

(Trecho do Caderno de Campo, 2015 - CCBB)

É possível notar que algumas questões do cotidiano que atingem a realidade das unidades escolares como, por exemplo, a mediação dos conteúdos e a falta de tempo, também ocorrem nos equipamentos culturais, gerando a necessidade de reinventar o texto político. Em entrevista para Mainardes e Marcondes (2009) sobre justiça social, pesquisa e política educacional, Stephen Ball afirma que

o processo de traduzir políticas em práticas é extremamente complexo; é uma alternação entre modalidades. A modalidade primária é textual, pois as políticas são escritas, enquanto que a prática é ação, inclui o fazer coisas. Assim, a pessoa que põe em prática as políticas tem que converter/ transformar essas duas modalidades, entre a modalidade da palavra escrita e a da ação, e isto é algo difícil e desafiador de se fazer. E o que isto envolve é um processo de atuação, a efetivação da política na prática e através da prática. É quase como uma peça teatral. Temos as palavras do texto da peça, mas a realidade da peça apenas toma vida quando alguém as representa. E este é um processo de interpretação e criatividade e as políticas são assim (p. 305).

Na seção seguinte, são apresentadas considerações acerca das experiências vivenciadas pelos alunos nos diferentes equipamentos culturais e a tentativa de perceber se essas experiências promoveram ou não uma formação cultural de qualidade. 


\subsection{A formação cultural de qualidade e as múltiplas experiências}

Para as observações serem realizadas, precisava estabelecer critérios para identificar o que seria uma formação cultural de qualidade. Para minha surpresa, na literatura, não foi encontrado nenhuma definição explícita para formação cultural de qualidade, mas indícios de que a mesma está fortemente relacionada à experiência. Dessa forma, através da leitura de trabalhos de diferentes autores, o subsídeo para criar critérios que possibilitassem a percepção de uma formação cultural de qualidade partiu do livro Experiência e Educação de John Dewey (2010). Dessa forma, anteriormente ao período de observação em campo, foram estabelecidos critérios para viabilizar a percepção se a formação cultural ofertada aos alunos era ou não de qualidade. As noções selecionadas a partir do referencial teórico foram: i) o ambiente afeta as experiências educacionais; ii) a experiência permite o crescimento direcionado: os roteiros e a mediação; iii) os hábitos afetam a formação de atitudes e iv) Situações e modos de interação são inseparáveis.

\subsection{O ambiente afeta as experiências educacionais: o acolhimento}

De modo geral, independentemente do equipamento cultural, o acolhimento do grupo participante do Projeto foi feito de modo semelhante. Dialogando com Garcia-Canclini (2000), Carvalho (2016) apontou para a questão da ritualização vivenciada nos equipamentos culturais, sacralizando o espaço e seus objetos, impondo, inclusive, uma ordem.

$\mathrm{Na}$ chegada aos espaços, os alunos eram conduzidos pelos mediadores a uma sala especial ou ao hall de entrada e davam início à atividade através de algumas perguntas sobre: localização da escola, se haviam feito um bom deslocamento, se sabiam onde estavam e o que fariam, se já conheciam o espaço. Em seguida, os mediadores faziam uma breve fala sobre o equipamento cultural, como seria a atividade e as regras do espaço. Além disso, com exceção de uma situação, perguntavam aos alunos se desejavam beber água ou ir ao banheiro antes de iniciarem o roteiro e, em alguns casos, foi também dado tempo para lanchar.

Aluno: Estou cheio de fome!

Mediadora: Vamos dar dez minutos para lancharem lá fora.

(Trecho do Caderno de Campo, 2015 - Espaço Oi Futuro)

Aluno: Estou com fome! (Ao passarmos pelo bistrô em direção ao terraço). 
Aluno: Aqui é tudo caro! (Chegando ao terraço, sentaram-se à mesa, pegando refrigerante e biscoitos nas mochilas).

Mediador: Não vamos comer aqui não. Vamos descer para entrar no museu. Não dá tempo!

Aluno: A primeira coisa que vou fazer no ônibus é comer e, depois, dormir.

(Trecho do Caderno de Campo, 2015 - Espaço Oi Futuro)

Os mediadores de alguns equipamentos culturais sensibilizavam-se com as distâncias percorridas pelos alunos para que chegassem aos espaços e escutavam, de fato, os depoimentos dos alunos, como no caso acima, e respeitavam o tempo e as necessidades de cada grupo. Por outro lado, na segunda situação retratada, o mediador preocupava-se com o tempo na perspectiva do funcionamento das atividades propostas pela instituição. Coutinho (2013) chama a atenção para a questão da formação de educadores como mediadores culturais, com a capacidade de se comunicar, de ter atenção, mas também com a capacidade de flexibilizar a comunicação para os diferentes públicos, defendendo que

se pensamos no público, é preciso buscar identificar e situar quem é este público. Abrir, por esta via, um complexo campo de pesquisa, pois o público não é uma entidade abstrata. Se buscamos ampliar o acesso desse público aos bens culturais, é necessário reposicionar nossa ação e refletir sobre as nossas próprias concepções de arte e cultura e sobre as concepções que norteiam os projetos educativos das instituições. (p. 154).

É fato que os responsáveis pelo acolhimento e esse momento de abertura de um diálogo era fundamental para o estabelecimento de vínculo com os alunos e para a construção da interação com os mesmos. Vários mediadores dos espaços investigados buscaram informações do cotidiano dos alunos na tentativa de estabelecer relações com o que estava sendo apresentado ao longo do roteiro, no sentido de revelar que eles já traziam conhecimentos, valorizando, assim, o repertório de cada grupo, como, por exemplo, durante um momento de interação da medidora com o grupo de alunos:

Mediadora: Aqui vão ver arte?

Aluno: Mais ou menos.

Aluna: Ou é sim ou é não.

Aluno: Acho que sim, já tem arte aqui (apontando para as estátuas do hall de entrada do centro cultural).

Mediadora: O que mais acham que veremos aqui?

Aluna: Tribunal, advogados, juiz, júri popular.

Mediadora: Estão antenados! E o que está escrito ali?

Aluno: Dura lex. Sed lex.

Mediadora: Que língua é essa?

Aluno: Grego. 
Aluno: Romano.

Aluna: Latim.

Mediadora: O significado é "Dura lei. É a lei”. Vocês acham que a lei é dura?

Aluno: O máximo de prisão no Brasil são 30 anos, mas nos EUA é diferente.

Mediadora: Sabiam que existe um Conselho Internacional de Justiça que prevê que o tempo máximo ideal é de 30 anos? Nosso país não está atrasado! Vocês acham que a justiça é para punir ou reabilitar?

Aluno: Reabilitar.

Aluno: Mas, não é assim que acontece sempre.

Mediadora: Vocês acreditam que o ser humano pode se reabilitar?

Aluno: Sim.

Aluno: Não. Posso perdoar, mas não quer dizer que vão mudar.

Mediadora: Quem é corrupto?

Aluno: Polícia.

Mediadora: Só a polícia?

Aluno: Governadores, prefeitos.

Mediadora: De onde saem essas pessoas?

Aluno: Do voto!

Mediadora: Só do voto? E os policiais? Saem do nosso meio. Quem faz as leis?

Aluna: Os juízes.

Mediadora: Não.

Aluno: Os deputados.

Mediadora: Isso! E os senadores.

Em seguida, a mediadora convidou os alunos a subirem e uma atriz representando a deusa Têmis (figura 20) iniciou o roteiro com os alunos.

(Trecho do Caderno de Campo, 2015 - CCPJ)

Figura 20: Deusa Têmis.

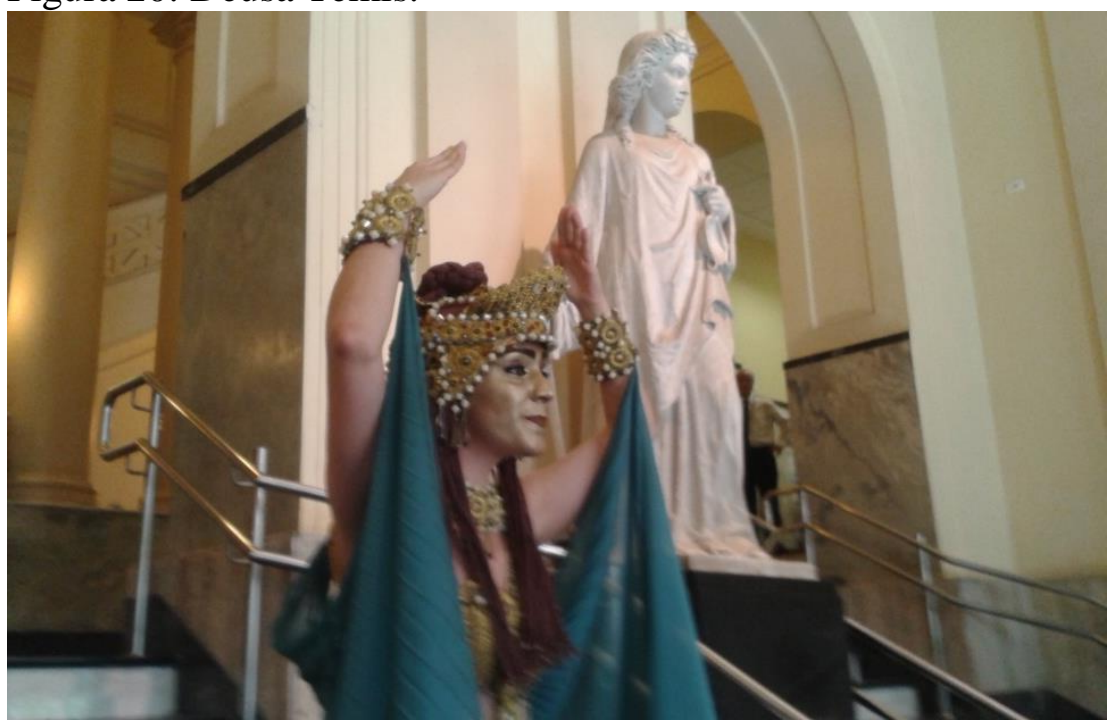

Fonte: Pesquisadora.

A conversa inicial proposta pela mediadora, ainda que tendo sido interrompida devido ao tempo proposto para o início da atividade teatralizada, tentando dialogar com a realidade dos alunos e, assim, construir vínculo é algo que Koptcke (2003) destacou nos estudos de Hooper-Greenhill (1991). 
O verdadeiro potencial educativo dos museus decorre de sua capacidade em mobilizar conceitos referentes aos conteúdos apresentados de forma dinâmica e interativa onde a emoção e a imaginação têm papel de destaque. A visita deve estabelecer laços afetivos e imaginativos entre o público e os objetos, os espécimes expostos, os monumentos históricos. Tais laços terão maiores chances de desenvolvimento quando interligados à realidade, às referências do indivíduo, seja este adulto ou criança. (p. 116).

Outro exemplo que caracteriza uma aproximação inicial do universo dos adolescentes está retratado abaixo, quando o mediador começa a problematizar a cultura brasileira, as suas influências e a transmissão. Tal estratégia, além de conseguir atrair a participação dos alunos, oportunizou introduzir uma discussão que permeia todo o roteiro da visitação, já que a casa-museu é repleta de obras de arte de diferentes culturas.

Mediador: Vocês falaram de dança, não é? Falaram de Hip hop, funk, forró, enfim, outras coisas e se a gente pensar na origem, na verdade não são brasileiras. Elas são adaptadas de outros lugares. A língua é a mesma coisa, se a gente pensar no nosso português aqui e pensar no português de Portugal, por exemplo, a gente vai ver uma série de diferenças. Por que que acontecem essas diferenças?

Aluna: Por que não é a mesma coisa.

Mediador: Oi? Por que que vocês acham que acontece? Lembra que eu falei que são organismos que vão recebendo uma série de incorporações?

Aluno: Mistura de culturas.

Mediador: Mistura de culturas, se a gente for realmente estudar o nosso português, a gente vai ver que há uma série de inserções de palavras africanas, de palavras indígenas, de palavras de outros lugares.

Aluno: Inglesas também.

Mediador: Inglesas também. Cita uma palavra que a gente usa cotidianamente que seja uma palavra inglesa.

Aluno: Facebook

Mediador: Facebook

Aluna: Whatsapp.

Aluno: Twitter.

Mediador: Whatsapp, Twitter.

Aluna: Comida.

Mediador: Oi? Comida?

Aluna: Hot-dog.

Mediador: Se você falasse Hot-dog, hambúrguer, fast food, aí sim. Por que eu levantei a questão da cultura? Porque a gente vai ver muito sobre isso ao longo da casa. Para a gente poder ter um pouco mais de clareza do que significa isso, porque a gente fala de cultura, a gente acaba pensando no outro, mas, às vezes, se esquece um pouco da nossa, de como a nossa é uma cultura que recebe o tempo inteiro e é por isso que eu quero que vocês mantenham essa ideia da cultura como um organismo vivo que está crescendo o tempo inteiro. Está recebendo uma série de inserções o tempo inteiro.

Aluna: A cultura é recebível até porque se você pensar que a cultura de antigamente serve para a gente, e a nossa vai servir para os nossos filhos, netos e bisnetos que vão continuar.

Mediador: Exatamente! Se a gente olhar a história lá desde o início, a gente vai vendo que muitas coisas do passado, tem reflexo ainda hoje. 
Aluna: Influencia.

Mediador: Sem dúvida nenhuma, em vários aspectos, em várias instâncias. Então, a partir desse momento, já com essa ideia de cultura na cabeça, a gente vai dividir novamente o grupo para poder entrar na casa.

(Trecho do Caderno de Campo, 2015 - FEK)

No roteiro proposto pelo Museu Nacional (MN/UFRJ) também foi possível perceber a tentativa de estabelecer um elo entre o acolhimento e a temática da exposição. Com a pergunta "De onde vocês vieram?", buscava-se introduzir a ideia de que o nosso planeta e os seres vivos também têm uma origem e uma história a ser contada pela ciência.

Mediadora: De onde vocês vieram?

Aluno: Eu vim da barriga da minha mãe!

Alunos: (risos)

Aluno: Eu vim do céu.

Mediadora: Boa resposta! Alguma outra resposta? ... Pode ser da escola, pode ser da barriga da nossa mãe, pode ser também de Deus, Deus nos criou, pode ser também dos alienígenas, podem ser várias coisas. A gente vai mostrar um pouco da visão da ciência sobre de onde nós viemos. O que a gente vai ver aqui são teorias que a todo momento muda, até porque a ciência muda toda a hora, então a teoria que a gente vai falar agora daqui a cinco ou seis anos, ou daqui a seis meses pode mudar completamente. Então é só uma pequena visão para ajudar vocês, a gente vai começar a 4,6 bilhões de anos atrás, no início de nosso planeta. Todo mundo viu aquela pedra ali na frente?

Aluno: Eu vi.

Mediadora: Aquilo ali é um meteorito ou é meteoro?

Aluno: Meteoro.

Mediadora: Alguém sabe responder se ele é meteorito ou meteoro? Então, meteorito, seria meteoro de verdade, seria aquele corpo celeste que está no espaço... Meteorito seria o corpo celeste puxado pela gravidade, no caso do nosso planeta, e entrou na atmosfera, fora da atmosfera ele é meteoro, dentro da atmosfera ele é meteorito. E como ele vem em uma velocidade muito grande, ele geralmente pega fogo, muitas vezes nem consegue chegar aqui na Terra. Alguns conseguem, e quando eles conseguem, eles podem variar de tamanho. Eles podem ser tão pequenos como daquele tamanho lá em baixo. Aquele lá de baixo é o meteorito de Bendegó. Ele foi encontrado aqui no Brasil.

Aluno: É original?

Mediadora: Sim, é original. Aquele meteorito ali, para vocês terem uma noção, tem quatro quilos ${ }^{96}, 5$ bilhões de anos, ele é a idade do nosso planeta.

Aluno: Uau!

Mediadora: Então, o fóssil ${ }^{97}$ mais antigo que vocês vão poder tocar é aquele meteorito lá embaixo.

Aluno: Ele é muito antigo! (Trecho do caderno de campo, 2015 - MN/UFRJ)

\footnotetext{
${ }^{96}$ A mediadora cometeu um engano. O meteorito de Bendegó tem 5,36 toneladas $(5.360 \mathrm{~kg})$.

${ }^{97} \mathrm{O}$ meteorito não é um fóssil. Novamente, é importante sinalizar alguns erros conceituais que foram apresentados ao longo da visitação.
} 
Foi nítida uma preocupação com o contexto dos alunos por parte dos mediadores das diferentes instituições, aspecto interessante porque a experiência não transcorre em um vazio, mas sim dentro de indivíduos marcados por uma história de vida. Concordando com Dewey (2010):

Uma responsabilidade fundamental do educador não é apenas estar atento ao princípio geral de que as condições ambientais modelam a experiência presente, mas também reconhecer concretamente que as circunstâncias ambientais conduzem a experiências que levam ao crescimento. Acima de tudo, o educador deve saber como utilizar as circunstâncias físicas e sociais existentes, delas extraindo tudo o que possa contribuir para a construção de experiências válidas. (p. 41).

\subsection{A experiência permite o crescimento direcionado: os roteiros e a mediação}

Sobre os roteiros estabelecidos pelas instituições e a ação dos mediadores na execução desses roteiros nos espaços investigados, a maior parte das instituições fez uma abordagem interativa, ressaltando que não havia apenas uma possibilidade de leitura do que seria visto. Vários mediadores lançaram distintas questões aos alunos, possibilitando, assim, que pensassem sobre o que viam e tentassem relacionar com outros conhecimentos, conforme extratos abaixo, retirados do caderno de campo.

Mediadora (CMAHO): Eu sou (nome da mediadora). Então gente, todo mundo já entrou? Vou pedir só uma coisa, como somos muitos e eu sou só uma para falar, quem quiser falar, quem quiser comentar alguma coisa, levanta a mão para todo mundo poder ser ouvido e se entender bem. E outra coisa que é a mais importante de todas. Hoje, é que eu não estou aqui para ensinar nada para vocês, eu estou aqui para a gente conversar, para a gente debater questões e para a gente pensar junto sobre as questões que essa exposição traz para a gente. E não existe certo e errado aqui então vocês estão livres para falar o que vocês quiserem, que ninguém vai julgar nada aqui hoje. E outra coisa antes da gente começar mesmo, é uma informação que é muito importante nessa exposição, que é essa aqui. Essa plaquinha, todas as vezes que vocês forem para o museu, para qualquer museu que seja, qualquer exposição, sempre tem uma plaquinha de identificação, com o nome do autor da obra, com o nome da obra, o ano que a obra foi feita, e do que ela é composta, porque hoje em dia a gente tem obras de artes de todos os tipos de materiais que a gente pode imagina... mas, do que que isso é feito? Então quem tiver alguma dúvida, tem sempre essa plaquinha. Então, eu vou convidar vocês a olharem essas fotografias e esses textos para a gente poder debater um pouco sobre essa instalação. Alguém já ouviu esse nome antes, instalação? (Trecho do caderno de campo, 2015 - CMAHO)

Mediadora (FEK): Vocês fazem a visita. Podem ficar à vontade conforme os olhos passarem pelo espaço e o que chamou a atenção de vocês. Vamos fazer um combinado: não vamos apontar para as peças que chamaram a atenção. Vamos descrever o que estamos vendo para ver se o grupo identifica. (Trecho do caderno de campo, 2015 - FEK) 
(Alguns alunos partiram do hall de entrada sozinhos em direção aos andares superiores. A mediadora pediu que voltassem).

Mediadora (Espaço O Futuro): Quer dizer que vocês iam dar um giro sem nos convidar? Até gostei disso porque esse espaço é de vocês. Isso é autonomia. Como aqui é como se fosse uma casa, nós conhecemos esse lugar, aí acho que se forem com a gente vai ser mais legal. Se eu fosse à escola de vocês, quem me receberia e apresentaria o espaço?

Aluna: A gente!

Mediadora: Isso. Eu não saberia andar pelo prédio sozinha. Poderia querer usar o banheiro e não saberia onde é. (Trecho do caderno de campo, 2015 - Espaço Oi Futuro)

Concordando com Semedo (2005, p. 14), “os museus não reproduzem meramente a realidade, os museus (re)definem essa mesma realidade no contexto da sua própria ideologia e, por essa razão, devem ser compreendidos como performers, criadores de sentido, como prática de significação”. Nesse sentido, a ação dos mediadores é fundamental para que o público seja cativado e, assim, ocorra de fato uma democratização cultural, provocando o desejo do retorno aquele espaço.

A tentativa de deixar os alunos sentindo-se à vontade nos espaços visitados permitiu constatar que o grupo de mediadores observados demostrava, de modo geral, facilidade em lidar com os adolescentes, desejando a participação e a presença desse público. Muitas vezes, os alunos participaram de modo intenso, indagando a respeito das obras que viam e das que não haviam sido contempladas durante o percurso, questionavam quando não entendiam algo, teciam comentários sobre aspectos diversos, relacionando com o cotidiano e outros conhecimentos que possuíam. De acordo com Dewey (2010),

do ponto de visto do crescimento como educação e da educação como crescimento, a questão é se o crescimento nessa direção promove ou atrasa o crescimento em geral. (...) Qual o efeito do crescimento em uma direção especial sobre as atitudes e hábitos capazes de abrir caminhos para outras direções? (p. 37)

Foi possível constatar um esforço por parte das equipes para que os alunos pudessem exercer de forma ativa o seu direito à formação cultural, gerando a possibilidade de abrir novos horizontes. Em diversas situações como as relatadas nesta pesquisa, os alunos foram confrontados pelos objetos, pelos outros sujeitos e consigo mesmo. Visto que esses aspectos são dimensões da experiência estética, Gadamer (2005, p.116-117) esclarece que

Na vivência da arte se faz presente uma riqueza de significados que não pertence somente a este conteúdo específico ou a esse objeto, mas que representa, antes, o 
todo do sentido da vida. Uma vivência estética contém sempre a experiência de um modo infinito. E seu significado é infinito justamente porque não se conecta com outras coisas na unidade de um processo aberto de experiência, mas representa imediatamente o todo.

Pelo fato da experiência estética ser uma experiência da própria historicidade, em que o sujeito experimenta a si mesmo, ela apresenta uma marca autoformativa. Para Gadamer (2005, p. 50), a experiência com a arte permite "reconhecer no estranho o que é próprio, familiarizar-se com ele, eis o movimento fundamental do espírito, cujo ser é apenas o retorno a si mesmo a partir do seroutro."

Em frente à obra Em Segredo (figura 21), exposta no Centro Municipal de Arte Hélio Oiticica, a mediadora perguntou o que os alunos eles achavam que a peça representaria.

Aluna: Amor.

Aluna: Pode falar do aborto.

Mediadora: O que acham sobre o aborto? É uma temática polêmica!

Aluno: Não pode.

Mediadora: Já ouviram a expressão aborto masculino? Um pai também não mata um filho ao abandoná-lo?

Aluna: A professora falou sobre as mães solteiras e os pais irresponsáveis e qual seria o verdadeiro papel de um pai.

Aluna: Não entendi!

Mediadora: Por que temos que entender? Ah, isso não foi um fora!

Professora: Você pode sair com perguntas.

Mediadora: Ninguém é obrigado a entender o que o artista desejou falar. Essa obra pode ser o que quiser a partir de agora. Depende da sua sensibilidade. Arte tem a ver com vida.

(Trecho do caderno de campo, 2015 -CMAHO)

Figura 21: Obra Em Segredo (Exposição Álbum de família)

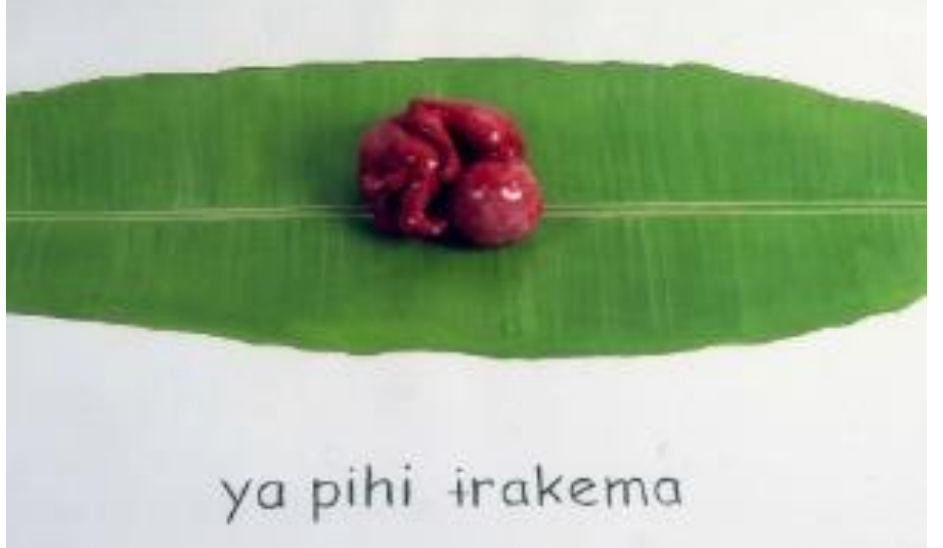

Fonte: UOL/Divulgação ${ }^{98}$

98 Disponível em: http://guia.uol.com.br/rio-de-janeiro/exposicoes/noticias/2015/08/04/compinturas-e-fotografias-mostra-coletiva-explora-o-tema-familia.htm. Acesso em: 2 mar. 2017. 
No fragmento acima é possível perceber como as exposições mexiam com as histórias de vida e criavam a possibilidade de ampliar repertórios, fazer novas reflexões no encontro consigo e com o outro, em que os mediadores colaboravam pela busca da compreensão. Segundo Flickinger (2014),

Quando se fala de "compreender" algo, no sentido estrito da palavra, não se trata apenas de entender a razão de ser ou a constituição do objeto de conhecimento. Nisso consiste o objetivo da explicação. Aquele que queira realmente compreender algo verá implicitamente questionado o seu próprio saber. A pessoa, seu interesse, sua expectativa e seu entendimento prévios influenciam nessa tentativa, como se o verbo "compreender" devesse ser lido como "trazer junto no anzol" a pessoa que tenta compreender. (p.37).

A postura da mediadora, ao afirmar que arte tem a ver com vida, é apontada no trabalho de Brito (2005). O autor defende que o museu é um lugar que desperta sentidos que estão intimamente relacionados à história de vida dos sujeitos, ressaltando que

O museu, que é o lugar onde se guardam e mostram objetos, é, principalmente, um lugar de imagens. Nos modos como eles são guardados, intencionalmente apresentados ou esquecidos nas suas reservas, como são expostos, iluminados e dados a ver nas exposições, os objetos despoletam uma multiplicidade de sentidos para além daqueles que lhes são apostados a partir do saber desenvolvido no museu. Eles resultam da experiência individual dos visitantes que os observam; dos conhecimentos e sensibilidades que convocam e articulam; e também dos contextos específicos em que são apresentados, conjunturas políticas, sociais, culturais, mais ou menos mediatizadas, e outros fatores exteriores à vida e ao Projeto do museu. (p. 158).

O trabalho de Flickinger (2014), acerca do pensamento gadameriano e suas relações com a educação, destaca a história de vida dos pais de Sócrates e a sua relação com a postura do filósofo, que ajudava seus interlocutores a alcançar um saber que já estava presente neles, só que esquecido e não ativado. Tal passagem remete a pensar sobre a postura dos mediadores e o quanto era muito mais interessante quando buscavam estabelecer um diálogo com os alunos da rede municipal, numa perspectiva maiêutica, trazendo à tona os conhecimentos.

Diz-se que a mãe de Sócrates era parteira, e o pai, escultor. Do ambiente em sua casa é possível deduzir o modo de educação experimentado pelo filho. Segundo o entendimento grego das profissões desses pais, nem a parteira nem o escultor ocupam-se com a produção ou criação de objetos; pelo contrário, em seu trabalho profissional eles entregam-se a um processo endógeno: à parteira cabe apoiar o processo natural do parto, enquanto o escultor procura dar visibilidade a uma das múltiplas formas já inscritas na pedra em que trabalha. A postura profissional dos dois tem caráter "maiêutico" - conceito grego que designa a tarefa de apoiar a realização de processos considerados endógenos e naturais. Em ambos os casos, 
tanto no do pai quanto no da mãe de Sócrates, trata-se da ativação de um potencial ainda oculto no interior do "material" com que lidam." (Flickinger, 2014, p. 16)

Em alguns momentos falhas também aconteceram, demonstrando certa resistência das instituições culturais em realizar essa abertura ao público adolescente, como pode ser notado no fragmento abaixo.

Enquanto os alunos estavam na última sala da exposição Picasso, comentando sobre o que viam, uma mediadora que atendia a um grupo de idosos pediu que os alunos fizessem silêncio.

Mediadora (CCBB): Se não querem ver a exposição, favor ir para os espelhos (figura 22).

Os alunos sentaram-se, ficaram quietos e depois saíram do espaço para visitar a linha do tempo.

(Trecho do caderno de campo, 2015 - CCBB)

Figura 22: Labirinto do fauno

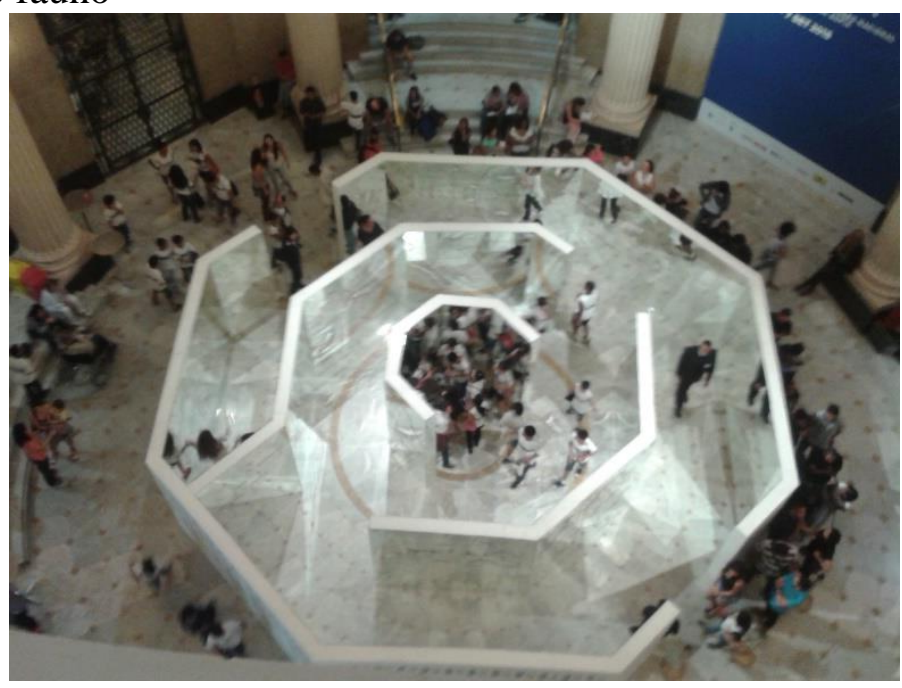

Fonte: Pesquisadora.

A situação acima relatada é apontada em outros estudos sobre as visitas escolares em museus e centros culturais. Em pesquisa realizada por Carvalho (2016), a autora aponta que, em alguns momentos, os monitores colocavam-se em posição de disputa pela atenção dos visitantes, não compreendendo que a exposição apresenta o potencial de despertar diferentes reações e emoções no público e, não necessariamente, uma atitude como expressar verbalmente o que observa, significa dispersão ou desinteresse. Segundo Flickinger (2014), o que levou Gadamer à origem da hermenêutica foi o seu encontro com a arte e o questionamento de como é possível compreendê-la. Existe um paradoxo entre observar uma obra de arte sozinho e na presença de um guia. 
Tomemos aquela situação comum, em um museu ou uma galeria de arte, quando um guia - especialista em história das artes - dispõe-se a acompanhar os visitantes. Estes, inicialmente gratos, pelas informações recebidas, começam a se irritar no momento em que as explicações detalhadas do perito fazem uma espécie de cirurgia da obra. A sensação é de que ela está sendo tratada como objeto-pretexto de que o guia se utiliza para mostrar os seus conhecimentos. $O$ fenômeno que causa a sensação paradoxal é o seguinte: por maior que seja a competência do perito, as explicações detalhadas ameaçam destruir exatamente a atração misteriosa que a obra exerce sobre o espectador ou ouvinte. Parece que no decorrer das explicações sofisticadas a obra vai perdendo aquele espírito oculto que o atraiu no primeiro momento. (p. 39).

Em vários momentos, foi possível também identificar comportamentos estereotipados como o controle excessivo do tom da voz nos equipamentos culturais. É como se houvesse uma etiqueta própria para frequentar museus e centros culturais. É claro que existem regras em cada espaço e é importante que sejam cumpridas, no entanto, as mesmas não podem inibir a experiência e todo o potencial que a envolve.

Museus consolidam hábitos e costumes, levando o visitante a falar em voz baixa, andar em passos curtos, seguir trajetórias sem fim sem indagações ou surpresas. Regras disciplinares controlam corpos e movimentos. Também a suntuosidade dos objetos dispostos, a falta de informação sobre eles, leva o visitante a reverenciá-los ao invés de tentar compreendê-los. Os museus muitas vezes ocupam antigos palácios, mas, mesmo quando criados para abrigar coleções, procuram reproduzir a imponência de residências majestosas. Sem dúvida, estas são características presentes no Louvre e no British Museum (Bennet 1995), mas também presentes em inúmeros museus brasileiros. Estes não são necessariamente palácios extremamente suntuosos, mas em grande parte labirintos pouco sinalizados e capazes de constranger qualquer cidadão comum que pela porta da frente se aventure a uma visita (SANTOS, 2002, p. 89).

Por trás da situação acima relatada também está presente a concepção de jovem como problema. A mediadora citada em evento anterior julgou que os alunos não estavam atentos às obras e que o movimento e as falam ocorriam em virtude de estarem fazendo bagunça, ou seja, não foi percebido o interesse que os adolescentes apresentavam naquele espaço podendo, inclusive, gerar um sentimento de não pertencimento e de recusa a outras idas aos espaços culturais. Dayrell e Gomes (2009, p.2) afirmam que

a questão é, ao conceber o jovem de uma maneira reducionista, vendo-o apenas sob a ótica do problema, as ações em prol da juventude passam a ser focadas na busca de superação do suposto "problema" e, nesse sentido, voltam-se somente para os setores juvenis considerados pela sociedade, pela escola e pela mídia como "em situação de risco". Tal postura inibe o investimento em ações baseadas na perspectiva dos direitos e que desencadeiem políticas e práticas que focalizam a juventude nas suas potencialidades e possibilidades. 
Outro aspecto negativo foi, novamente, o quesito tempo. Enquanto no Centro Cultural do Banco do Brasil e no Espaço Oi Futuro, por exemplo, os alunos queixavam-se sobre a falta de tempo para apreciar a exposição, em alguns roteiros, a queixa versava sobre o longo trajeto e a quantidade de conteúdo, reduzindo, em alguns casos, a atenção e a participação dos alunos. Apareciam "sintomas" de dispersão e cansaço em alguns trajetos, especialmente notados no Museu Nacional da UFRJ, como é possível observar a seguir.

Com mais de uma hora de roteiro sem tempo para sentar e com uma quantidade enorme de informações sobre evolução, um grupo cada vez maior ficou disperso (17 alunos), mexendo no celular, e deitaram-se no chão, apoiando-se uns no colo dos outros.

Professor: Ela (a mediadora) não devia entrar tanto nos detalhes biológicos para não se comprometer. Os alunos estão ficando cansados. Até eu não entendo muito de evolução! (Trecho do caderno de campo, 2015 - Museu Nacional da UFRJ)

Enquanto a mediadora tentava fazer um fechamento com os alunos, dentro do Museu das telecomunicações, os mesmos continuavam ouvindo e vendo vídeos".

Mediadora: É, acho que a gente se desconectou... Vocês estão com necessidade de ver mais coisas? Não dá para ver tudo num dia só. São seis horas de exposição. Voltem! (Trecho do caderno de campo, 2015 - Espaço Oi Futuro)

Mediadora: Aqui fazemos uma mediação diferente da sala de aula em que vocês tem liberdade para falar. Diferente da escola. Aqui não é lugar de opressão. Venham mais vezes, tragam a família mesmo sem ser pela escola. Sei que foi chatinho, falo muito, mas estou tentando falar menos nas salas. Muito obrigada! (Trecho do caderno de campo, 2015 - Museu Nacional da UFRJ)

Segurança: Vou colocar o vídeo mais rápido da Sala dos Profetas porque o outro grupo já está aqui na porta.

Aluno: Mas, eu queria ver o do Leonardo Da Vinci ou do Albert Einstein.

Pesquisadora: Por qual razão?

Aluno: Porque já ouvi falar muito sobre eles.

Aluno: O Albert já foi reprovado e queria uma escola que não podia entrar porque não tinha idade.

Pesquisadora: Como você sabe sobre isso?

Aluno: Vejo um canal no YouTube "Você sabia?". Vejo todos os dias. (Trecho do caderno de campo, 2015 - Espaço Oi Futuro)

Perceber os sinais que os alunos demonstravam, tanto nos momentos de maior ou menor interesse, foi um aspecto não contemplado na ação da que equipe de alguns equipamentos culturais observados ao longo do trabalho de campo. A atenção para esse aspecto poderia se configurar como ponto fundamental para continuar motivando o grupo até o final da exposição proposta. Welsch (1995, p. 18) destaca que "uma esteticização total leva em direção ao seu oposto. Onde tudo 
é belo, nada mais é belo; estimulação ininterrupta conduz ao esbotamento; esteticização vira anestetização.”

\subsection{Os hábitos afetam a formação de atitudes}

Ao final dos percursos nos diferentes equipamentos culturais, os professores entrevistados eram convidados a relatar se percebiam mudanças nos alunos e na escola através da participação no Projeto Escola e Museu. Dialogando com Dewey (2010, p.35), a intenção ao incluir esse questionamento, decorre da compreensão de que

A concepção ampla de hábitos envolve a formação de atitudes emocionais e intelectuais; envolve nossas sensibilidades básicas e nossos modos de receber e responder a todas as condições com as quais nos deparamos na vida.

De modo geral, os professores apontaram aspectos positivos em relação às atitudes dos alunos, tanto intelectuais quanto relacionais, e novas demandas na escola, como é possível observar nos relatos abaixo.

Docente 17: Ah, com certeza, eles têm agora uma visão, eles começam a discutir em cada ambiente, porque cada local de visitação foi diferente, o Oi foi tecnologia, Eva Klabin eles começaram a discutir a relação da riqueza, a relação do poder e como a cultura ela também é ligada ao poder e à situação financeira, eu acho que brotou discussões muito interessantes. Grandes mudanças na escola, só por causa de um projeto acredito que não, tem que ser o todo, trabalhar a região, trabalhar a evasão, é uma área que é muito complicada, então ajuda sim, mas é mais um elemento, não o único.

Docente 8: Olha, alguns deles dizem que voltam sem a nossa ajuda, eles já pegam o metrô e vem, falam com a família sobre o espaço, pesquisam mais sobre o espaço que mais gostaram... Então, eu acho que a coisa pra eles vai mudando bastante, mais o nono ano que está nessa transição entre a escolinha do bairro e tentar uma coisa maior como CEFET, FAETEC ... Ele vai sair do bairro, ele abre horizontes pra esses garotos assim.

Docente 6: Na escola não, mas neles sim, porque fica um burburinho quando volta, e eles ficam falando, todo dia, quando vai ser o próximo, a motivação da turma é uma coisa assim que eu acho que para eles também... o crescimento deles, eles ficam diariamente mais motivados a conhecer museu e por conta das visitas eles ficam para a professora de artes, e aí quando você vai dar arte gótica? E história, e aí quando você vai dar renascimento? Porque a gente estudou não sei o que... Então, eles ficam tentando motivar os professores a ensinar, então o despertar do conhecimento tá aí.

Docente 5: Eles mudam, eu tenho experiência já, eu fui diretor de um colégio do Estado, a gente teve experiência, inclusive levei aluno pra São Paulo, e a mudança era grande. Em médio e longo prazo que você percebe, então o aluno ele vê que ele pode ir a outros lugares, que ele tem coisas para ver, ele tem coisas para fazer, então abre a perspectiva deles, então eu acho bem legal. 
Docente 7: Ainda não, porque eu acho que a gente não teve a ideia do resultado, o que a gente vai desdobrar disso ainda não deu tempo de fazer. Assim ainda não percebi alguma coisa clara para te falar, mas eu espero que já tenha tido, uma valorização desses espaços. Eu acho que tem no sentido, por exemplo, deles agora dizerem que até já foram nesses lugares de novo com os pais mostrar. A primeira entrevista que eu fiz com eles, eles já tinham ido em um lugar, eu perguntei para eles: você chamou os seus pais para ir lá? Para ver? Ah, chamei! Se vai, são outras possibilidades, mas já despertou o interesse de falar: oh pai tem esse lugar aqui, vamos! E uma aluna foi no CCBB de novo com os pais.

Docente 9: Olha, por enquanto na escola ainda não, porque é muito recente, é só o segundo passeio. É, nos alunos sim, alguns melhoraram o comportamento, é, começaram a se interessar um pouco mais para saber o que são as coisas. Agora, como eu falei, está no início, vamos ver os próximos. Tenho esperança que CCPJ, Museu Nacional, o Eva Klabin que tem áreas que eles podem ter mais contato com as obras, desperte mais ainda o interesse deles, mas, mudanças tem, de comportamento, contato com o que está acontecendo, com a localidade, isso já dá para ver, mas na escola em si ainda não.

Docente 16: Nos alunos que estão participando do projeto eu também achei que eles estão mais abertos, eles estão conseguindo refletir mais, durante as aulas eles estão questionando mais as coisas, nos primeiros, hoje já é o sétimo museu, nos primeiros eles tinham aquela coisa de ficar em silêncio, porque eles iam errar e conforme foi passando as visitas agora eles já estão mais soltos, já perguntam mais, e isso está refletindo na escola também, eles estão tendo mais responsabilidade, a gente está passando sempre algumas perguntinhas depois da visita, eles tem aquela responsabilidade de entregar que não acontecia muitas vezes com as atividades da escola, então eles estão com mais questão de entregar os trabalhos, entregar o trabalho do museu, os próprios trabalhos com outros professores também.

Docente 10: Olha, eu já sou um apaixonado por arte, já acho importante, a grande mudança que gera mesmo é o retorno, a gente tem um retorno emocional muito grande, uma aproximação emocional maior com o aluno, o aluno ele se sente mais predisposto a se aproximar do professor, ele se sente mais à vontade com o professor fora da sala de aula, e isso enriquece, isso mostra pra gente que as vezes a barreira que separa o acesso que a gente tem ao aluno, essa dificuldade de alcançar o aluno que é tão criticada, é talvez por falta de oportunidades como essa, de sair da sala de aula, e de criar um espaço mais, um espaço menos formal, um espaço que o aluno se sinta mais à vontade, isso é muito importante e contribui sim na nossa formação, no nosso fazer pedagógico, ajuda a derrubar esse muro. A gente vê que esses alunos são mais participativos em aula, eles têm mais o que falar, mais o que perguntar, então isso gera uma participação maior, influencia na rotina, e faz talvez com que outros alunos tenha um pouco de ciúme, que isso é normal, outros que tenham um pouco de raiva, isso também é normal, mas todas essas emoções podem ser canalizadas para algo positivo, a funcionar. Então, isso torna a educação mais dinâmica, torna a escola mais ativa, isso funciona, repercute dentro da sala de aula também.

Para Gadamer (2005, p.166), na formação cultural através da experiência estética há uma relação entre subjetividade e objetividade e o indivíduo nunca fica intacto após a experiência. $\mathrm{O}$ autor denomina essa mudança de transformação em configuração, ou seja, 
Significa que algo se torna uma outra coisa, de uma só vez e como um todo, de maneira que essa outra coisa em que se transformou passa a constituir o seu verdadeiro ser, em face do qual o seu ser anterior é nulo. (...) a transformação em configuração significa que aquilo que era antes não é mais.

Cabe ressaltar aspectos interessantes que estão bem explícitos na entrevista do docente 10. O professor relata que a interação entre os alunos e os docentes melhorou e a questão do vínculo é algo determinante na aprendizagem do aluno. Freinet (1975) defendia que as aulas-passeio apresentavam duas consequências evidentes: a melhora na convivência professor-aluno e como é comum encontrar no decorrer das aulas-passeio elementos a serem explorados mais próximos do universo cultural da vida da escola, a volta à escola colabora para se estabelecer um clima menos formal do que nas aulas tradicionais.

Após as diferentes experiências nos sete museus e centros culturais, ainda que com intensidades distintas, os docentes relatam que os alunos não são mais os mesmos e os próprios alunos perceberam um movimento nos professores de valorização das atividades do Projeto Escola e Museu, como pode ser visto no trecho abaixo, retirado da fala de uma aluna que se apresentou no seminário de culminância.

\begin{abstract}
Aluna: E o interessante dessa parte dos professores é que quando começaram a ver, porque quando a gente está falando lá (na escola), nem todos os professores vão ao passeio, nem todos os professores vão à reunião, quando eles começaram a ver os vídeos, os depoimentos e os trabalhos, eles começaram a entender um pouco mais sobre o que era o projeto, aí passaram a compartilhar, tiveram até uma atenção maior com o trabalho que estava sendo feito, superinteressante. (Trecho do caderno de campo, 2015 - Espaço Oi Futuro Ipanema)
\end{abstract}

$\mathrm{Na}$ fala de alguns professores como, por exemplo, 10 e 16, é possível perceber o alcance de um dos objetivos do Programa Escola e Museu no que diz respeito ao aprofundamento da aprendizagem dos alunos pela apropriação de conteúdos de disciplinas das áreas científicas, de arte e de comunicação linguística, proporcionados nas visitas às instituições culturais. Um dos docentes relata que os alunos estão realizando com mais compromisso as atividades de outras disciplinas de professores que não estão envolvidos diretamente no projeto.

Ademais, na maior parte das entrevistas, como pode ser observado, por exemplo, nas falas dos docentes 9, 10 e 17, há o relato de que os alunos estão mais interessados, envolvidos nas atividades escolares e questionam mais sobre os conteúdos. Gadamer (2005, p. 94) afirma que 
A linguagem da arte é uma linguagem exigente e interpeladora. A arte não se oferece livre e indeterminada á interpretação que vem da disposição de ânimo, mas nos interpela com significados bem determinados. E o que há de maravilhoso e misterioso na arte é que essa interpretação determinada não representa um grilhão para nosso ânimo, mas justamente abre o espaço de jogo da liberdade lúdica de nossa capacidade de conhecimento.

A docente 7, apesar de incialmente relatar que ainda era cedo para falar sobre mudanças nos alunos, no final da entrevista destaca que uma aluna havia voltado ao $\mathrm{CCBB}$ com os pais, ou seja, foi possível encontrar um exemplo de audiência programada que gerou audiência espontânea. Nesse sentido, o Projeto Escola e Museu, ainda que de modo incipiente, cumpre outro de seus objetivos que é a formação de público de visitação a instituições e espaços culturais, decorrente do desenvolvimento do interesse de alunos e professores pela apropriação de bens culturais. Para verificar de modo mais robusto esse objetivo, decorrido um tempo da consumação do circuito, o setor de Extensividade da SME/RJ poderia realizar uma nova avaliação com os alunos. No capítulo seguinte, apresento a avaliação realizada pelos alunos imediatamente após o fim das atividades e retomo essa discussão, já que os alunos foram questionados quanto à visitação de equipamentos culturais após o término do projeto.

\subsection{Situações e modos de interação são inseparáveis}

De acordo com Dewey (2010),

Os conceitos de situação e interação são inseparáveis um do outro. Uma experiência é sempre o que é por causa de uma transação acontecendo entre um indivíduo e o que, no momento, constitui o seu ambiente. Se esse ambiente consiste em pessoas com as quais ele esteja conversando, o assunto da conversa também faz parte da situação. (...) O ambiente é, em outras palavras, quaisquer condições em interação com necessidades pessoais, desejos, propósitos e capacidades de criar a experiência que se está passando. (p.45).

Partindo desse princípio, foram observadas as relações que os alunos estabeleciam com o ambiente e como a visita mobilizava outras experiências, principalmente vivenciadas no contexto escolar.

Mediadora: Vamos andar mais pela Praça Tiradentes. Perto da escola de vocês tem praça?

Aluno: Tem sim! A "Boi lambeu".

Mediadora: Como é?

Aluno: Tudo quebrado.

Mediadora: Aqui é uma área que está sofrendo uma revitalização. (Contou a história da praça). 
Mediadora: E essa estátua? O que representa?

Aluna: Uma mulher.

Mediadora: O que mais tem?

Aluno: Um cachorro.

Aluno: É a fidelidade. O cachorro é fiel.

Mediadora: Vamos até a outra. O que é?

Aluno: É a união mesmo porque tem dois pombos na cabeça da estátua.

Mediadora: A estátua maior vocês acham que já foi restaurada?

Aluno: Não.

Mediadora: Já. Há quatro anos, mas mantiveram as marcas do tempo. Assim como nós temos maracas, cicatrizes. São parte da história.

Aluno: Aquela estátua também tem estilo nude. Aliás, até o cavalo. Muito detalhado.

Mediadora: Você reparou, não é?

Aluno: Essa estátua é a liberdade. O nome da minha escola é ... (o aluno citou o nome da escola, que se refere à liberdade), mas é uma liberdade cheia de grades.

Mediadora: Engraçado... Liberdade na escola com grades, liberdade num lugar tirando a do outro, um país na guerra luta pela liberdade tirando a do outro.

Aluno: Liberdade de expressão com opressão. (Trecho do caderno de campo, 2015 - CMAHO)

Ao perceber o sentido da palavra liberdade através da história de uma das

estátuas presentes na Praça Tiradentes, o aluno estabelece uma relação com a liberdade (ou falta dela) escolar. Para esse jovem, passou a ser antagônico a escola ter um nome que faz referência à liberdade, mas ser rodeada de grades. Em diálogo com as reflexões de Gadamer, Flickinger (2014) destaca que o filósofo

viu no diálogo um movimento em princípio aberto. Nele os interlocutores são forçados a revelar e questionar as suas próprias certezas, fundadas em experiências anteriores; e o diálogo se desenvolve fazendo deles "os seus" integrantes. (...) Tomando dessa maneira, salta aos olhos a proximidade estrutural do diálogo com o jogo. Como este, o diálogo exige antes de tudo a disposição dos interlocutores de entregar-se ao risco permanente de ver colocada em xeque suas supostamente inabaláveis certezas. Nenhum dos envolvidos é dono do processo; ao contrário, cada um encontra-se dentro de um todo, no qual é apenas um elemento, ainda que constitutivo. (...) o saber que brota do diálogo depende das pessoas envolvidas, com suas histórias, convicções e habilidades específicas. (p. 54-55)

A construção dessas novas ideias é fruto da formação cultural através da experiência estética, levando-se em consideração a ideia de jogo que Gadamer (2005, p.160) apresenta em que "todo jogar é um ser-jogado" porque o jogo ganha vida própria quando o sujeito é desafiado pela arte, ou, ainda,

O jogo, ele mesmo, é uma transformação tal que a identidade daquele que joga não continua existindo para ninguém. E a única coisa que podemos perguntar é qual é a "intenção" do que está aí. Os jogadores (ou poetas) não existem mais, existe apenas o que é jogado por eles. (p. 167).

Aluna: Esse cara é tão complexo na arte dele! 
Aluno: Isso daqui é um papel.

Aluno: Eu achei esse artista preguiçoso. A pessoa faz isso e fica rica.

Aluno: Vou tirar uma foto disso. Quando deixar trabalho em branco vou mostrar para a professora de artes que isso é arte.

Aluno: Eu faço um trabalho bonitão, me esforço, aí a professora vai lá e dá um cinco.

Mediadora: Esses quatro quadros são obras do artista, da mesa de trabalho dele.

Aluna: Ah, eu sabia! Vi que tinha rabiscos, números de telefone, manchas de café.

Aluno: Liguei para o número, mas ninguém atendeu.

Aluno: Ele usava a mesa como bloco de anotações.

(Trecho do caderno de campo, 2015 - Espaço Oi Futuro/Sala "Quase aqui"")

Nessa situação relatada acima, é possível perceber que o aluno faz uma comparação entre o valor conferido à obra de arte exposta e o valor que é dado à produção dele durante as aulas de arte. $\mathrm{O}$ aluno constrói um novo aprendizado através da formação estética, percebendo que há um jogo de hierarquia de valores conferidos às diferentes manifestações artísticas. Para Gadamer (2005, p. 171172),

Se a arte não é a variedade de vivências cambiantes, cujo objeto é preenchido cada vez com significado subjetivo como se fosse fórmula vazia, a "representação" terá de ser reconhecida como o modo de ser da própria obra de arte. Isso deveria ser preparado derivando o conceito de representação do conceito de jogo, na medida em que o representar-se é a verdadeira essência do jogo - e com isso também a obra de arte. Através de sua representação, o jogo jogado interpela o espectador e de tal modo que este passa a ser integrante do objeto, apesar de todo o distanciamento do estar de frente para o espetáculo.

Além das relações que os alunos estabeleciam entre as exposições e o cotidiano escolar, em alguns casos foi possível verificar que as experiências mobilizavam outras situações do cotidiano: o desejo de estar em uma posição hierárquica melhor, conexões com filmes de cunho científico, problemas de relacionamento etc.

Mediadora: Do que mais gostaram?

Aluno: Do tribunal menor.

Mediadora: Por que?

Aluno: O outro é mais bonito, mas lá no menor eu dominei.

$\mathrm{O}$ aluno ficou assentado no lugar de maior destaque no tribunal menor. (Trecho do caderno de campo, 2015 - CCPJ)

\footnotetext{
${ }^{99}$ São quatro tampos de mesas de madeira retiradas do seu ateliê, todas com resquícios de tintas, cortes, cola e outros resíduos de trabalhos desenvolvidos sobre a superfície. No centro de cada uma, ele (Daniel Senise) pintou um retângulo branco com tinta a óleo. Disponível em: http://oglobo.globo.com/cultura/artes-visuais/daniel-senise-leva-suas-questoes-artisticas-outradimensao-na-exposicao-quase-aqui-17349628\#ixzz4aCizkJjS. Acesso em: 2 de março de 2017.
} 
Aluna: (Nome de uma amiga), é culpada por vir ao tribunal com muita maquiagem! (Trecho do caderno de campo, 2015 - CCPJ)

Aluna: Por que os animais gigantes do Permiano Carbonífero morreram?

Mediadora: Acho que foi um ajuste no teor de gás oxigênio, mas eu não tenho certeza. A extinção que mais falam é a do período Mesozoico dos dinossauros. (Contou sobre o meteorito que caiu).

Aluna: E os clones de dinossauros do Jurassic Park?

Mediadora: Alguns insetos teriam ficado presos no âmbar e aproveitaram o DNA. Não sei muito sobre essa teoria, mas eu pessoalmente não acredito nela. (Trecho do caderno de campo, 2015 - MN/UFRJ)

Aluno: Pode mexer nisso aqui? (O objeto era um orelhão).

Mediadora: Pode.

Aluno: (O aluno pegou o telefone). Já disse para não casar com ela! (Trecho do caderno de campo, 2015 - Espaço Oi Futuro)

Aluno: Já viu o telefone do gato? O gato que fica na rua com o policial? Esse telefone é igualzinho! É o gato que tem vários amigos, o Batatinha. (Trecho do caderno de campo, 2015 - Espaço Oi Futuro)

Aluno: Rui Barbosa... Já ouvi esse nome. Não é um que faz novela? (Diante de uma obra que simula as Páginas Amarelas no Museu das Telecomunicações)

Pesquisadora: Esse é o Benedito Rui Barbosa.

Aluno: Mas, o Oscar Niemeyer é arquiteto. Jantei muito com ele em Copacabana. Sabe de um período que não gostei? A ditadura. Não podia fazer nada! Eu ajudei o Oscar Niemeyer a construir Brasília. Aquele negócio redondo que ele fez em Niterói foi ideia minha. Ele queria fazer quadrado, mandei um papo para fazer redondo.

(Trecho do caderno de campo, 2015 - Espaço Oi Futuro)

Aluno: Vocês já viram algum espírito aqui?

Aluna: Está tocando alguma coisa.

Mediador: É a Eva!

Alunos: Gritos e risos.

Professora: Pessoal, presta a atenção.

Mediador: É o nosso afinador, na verdade. Lembra que eu falei pra vocês que amanhã a gente vai ter um evento? O afinador está lá em cima no piano afinando o piano, é isso, não fiquem com medo.

Professora: Eles adoram fantasiar o negócio. (Trecho do caderno de campo, 2015 FEK)

Durante as observações, os alunos ativavam situações presentes na memória, mas também as reelaboravam de acordo com a experiência que estavam vivenciando, revelando um potencial para a criação através das atividades desenvolvidas nos equipamentos culturais. A capacidade de criação é constituída a partir de elementos extraídos da realidade. Os níveis de complexidade das combinações desses elementos é resultado da ampliação da imaginação e, assim, 
quanto mais ricas forem as experiências, mais material estará disponível. Segundo Vigotsky (2009),

A criação, na verdade, não existe apenas quando se criam grandes obras históricas, mas por toda parte em que o homem imagina, combina, modifica e cria algo novo, mesmo que esse novo se pareça a um grãozinho, se comparado às criações dos gênios. (p. 15-16).

Finalizando as observações acerca da qualidade da experiência vivenciada pelos alunos da rede municipal do Rio de Janeiro, foi possível concluir que os diferentes percursos culturais oferecidos pelas sete instituições parceiras da SME/RJ no Projeto Escola e Museu apresentavam aspectos positivos e outros que necessitavam de ajustes para que as atividades fossem ainda mais proveitosas. De qualquer forma, pode-se afirmar que os alunos foram estimulados a ampliar os seus horizontes culturais, através de propostas que buscavam mostrar que a arte não precisa ser vista e vivida apenas sob um ponto de vista, mas que o sentido dela perpassa pelo âmbito individual, pelas experiências anteriores, pelo que nos toca, pela história de vida. Ademais, o contato com os diferentes roteiros promoveu "encontros e desencontros" entre os sujeitos e os objetos, o que os desafiou a construir novos conhecimentos éticos, estéticos e científicos. Através do Programa Escola e Museu, os alunos também puderam ampliar o seu repertório pela ampliação da experiência cultural, afetando os hábitos inclusive em relação ao espaço escolar, no qual passaram a levantar mais questões e promover movimentos na escola, beneficiando alunos que não participaram do projeto. Para Vigotsky (2009, p. 30),

é quando temos diante de nós o círculo completo descrito pela imaginação que os dois fatores - intelectual e emocional - revelam-se igualmente necessários para o ato da criação. Tanto o sentimento quanto o pensamento movem a criação humana.

No capítulo a seguir são apresentados os dados sobre a avaliação feita pelos equipamentos culturais, docentes e alunos participantes do Projeto Escola e Museu na edição de 2015. 


\subsection{Avaliação do Projeto Escola e Museu}

Toda política educacional precisa ser avaliada para que seja possível realizar acertos e para que se entenda como a mesma está sendo aplicada. Nesta perspectiva, os sete equipamentos culturais foram convidados a apresentar uma avaliação durante o III Seminário Conexões Escola e Museu (2015), cujo porta voz foi o coordenador do Projeto de Educação da Fundação Eva Klabin. Além disso, durante o seminário, o setor de Extensividade divulgou a avaliação que docentes e alunos participantes do Projeto Escola e Museu realizaram online. A seguir são então apresentados os resultados dessas avaliações.

\subsection{Avaliação realizada pelas instituições}

Como mencionado acima, o coordenador do Projeto de Educação da Fundação Eva Klabin representou as instituições durante a apresentação realizada no III Seminário Conexões Escola e Museu e fez a sua fala apresentado um PPT com os impactos do Projeto Escola e Museu nos diferentes espaços culturais.

Coordenador do Projeto de Educação da Fundação Eva Klabin: Tendo em vista que cada espaço cultural oferece um acervo diferente, oferece proposta de trabalho diferenciado, então são experiências, são processos de experiências muito ricas, e aí a responsabilidade seria agora de falar os impactos do projeto nos espaços culturais. A minha ideia foi me comunicar com os demais espaços culturais para tentar obter alguns relatos. Eu consegui de alguns, ficaram faltando só dois. Mas enfim, eu acho que tudo o que vai ser dito aqui, dos outros espaços culturais também vai representar, essas falas vão representar os outros dois espaços que não estão aqui (no PPT), mas estão aqui (no auditório).

Abaixo, apresento os registros, na íntegra, das avaliações/impactos enviados por cada instituição cultural participante do circuito para o coordenador do Projeto de Educação da Fundação Eva Klabin. Tais informações foram retiradas, sem sofrer alteração, do PPT disponibilizado ao término do seminário, com a autorização da coordenadora do Projeto Escola e Museu.

De modo geral, foi possível notar que as instituições buscaram evidenciar os aspectos positivos, mas também os limites de suas ações. Compreenderam que não apenas os alunos, mas as próprias equipes dos museus e dos centros culturais também mudaram o olhar e foram sensibilizadas com as experiências vividas. Evidenciaram que um dos ganhos do projeto ocorreu porque atrelaram os roteiros ao cotidiano dos alunos. 


\section{A) $\mathrm{CCBB}$}

O Projeto foi desenvolvido no $\mathrm{CCBB}$, mas não com o devido acompanhamento e a necessária apreciação por parte da coordenação e da equipe da instituição, pois os roteiros da visitação foram feitos através de introduções à exposição "Picasso e a modernidade espanhola", e, após o término dessa exposição, foram oferecidas visitas ao prédio, através do programa denominado "Reconhecendo o CCBB". Os educadores sabiam do projeto e se colocaram, como sempre, na busca de mediações que fizessem valer a realidade, o olhar e a fala de cada indivíduo. Não é possível mensurar o que foi alcançado através de nossa proposta, aguardamos agora o que os alunos trarão de retorno.

Ressalto a validade do projeto e que cada instituição participante deve se colocar por inteiro no intuito de comprometer toda a equipe para o que de fato se quer alcançar quando se aproxima a escola do museu.

\section{B) CCPJ}

O Projeto Escola Museu balançou as estruturas do Antigo Palácio da Justiça. O complexo judiciário deve e merece receber grupos jovens e dos mais diferentes lugares da cidade, para se aproximar da população e estreitar o diálogo.

Os alunos foram os mais generosos possíveis. No começo, o Antigo Palácio da Justiça pareceu para eles um lugar chato, cheio de coisas antigas que não interessam a ninguém. Mas, aos poucos, perceberam como a justiça está presente no cotidiano, e mais, como a justiça tem vários significados. Já nós, educadores, aprendemos como esses jovens, cheios de vida e criatividade, estão atentos ao que acontece no mundo, como são críticos e sensíveis. E que fôlego para debater questões tão importantes! Essa energia tem de ser estimulada e desenvolvida sempre! Conosco, aqui no museu, e com vocês, aí na escola!

A riqueza de cada encontro possibilitou um crescimento da nossa atuação, assim como momentos emocionados com falas tão fortes e tão sinceras. De maneira muito orgulhosa digo que a noção de justiça foi de fato pensada e discutida.

Caros professores, temos aqui jovens maravilhosos a caminho de uma sociedade mais justa!

\section{C) CMAHO}

Não enviou avaliação. 


\section{D) Espaço Oi Futuro}

Os temas escolhidos para serem trabalhados durante este ano perpassam nosso cotidiano de visitas. Entretanto acreditamos que merecem cada um deles uma atenção individualizada, por serem bastante interessantes. Esses temas foram História da Cidade, Patrimônio, Arte, Memória e Diversidade Cultural.

Os temas estavam presentes no discurso de alguns professores. Eles falaram especialmente da relação com a cidade e nas instituições mais antigas sobre patrimônio.

Uma das visitas aqui no Oi Futuro foi elogiada por causa de uma conversa sobre a cidade e mobilidade, e em como isso influencia diariamente a vida dos alunos.

Próxima edição do projeto: Convidar os professores para uma visita individualizada e um acolhimento voltado para o interesse do professor;

Estudar a possibilidade de realizar visitas que incluam passeio na rua, aproveitando o entorno do museu, que possa ampliar a discussão sobre mobilidade, patrimônio e história da cidade;

As turmas deverão ser trabalhadas de acordo com seus interesses e objetivos

\section{E) Fundação Eva Klabin}

Promoveu mudanças de mentalidade nos gestores.

Propiciou relações / parcerias mais estreitas com os professores: visitas pedagógicas.

Fomentou a elaboração, juntamente com professores e estudantes, dos percursos e das ações realizadas:

- Processo de construir com e não mais construir para;

- Valorização da visibilidade e da voz do estudante: pedagogia da escuta disponível [desde o acolhimento];

- Empoderamento / Apropriação dos espaços e dos acervos;

- Diversidade cultural e suas reverberações: pessoas e espaço cultural - espaço cultural e pessoas.

\section{F) MAR}

A mudança de perspectiva do olhar, através do tapa-olho, e a dúvida que surge com a "pergunta", nos provocam a pensar sobre as significações que o Projeto 
Escola e Museu trouxe para o MAR nesse ano de 2015, marcado por uma forte produção artística dos estudantes participantes do projeto. $\mathrm{O}$ envolvimento das turmas com o circuito entre todas as instituições ampliou os olhares e relações com o MAR, instigando atravessamentos das práticas dos artistas em encontro com poéticas dos estudantes. Novas poéticas para novas formas de praticar o museu.

G) Museu Nacional/UFRJ

Não enviou avaliação.

Ao terminar a sua explanação sobre os registros enviados por cada um dos equipamentos culturais, o coordenador do Projeto de Educação da Fundação Eva Klabin disse:

Pra fechar, pra encerrar a minha fala, eu fiquei pensando... Como é que eu vou encerrar? Eu fiquei pensando em todo o circuito, todo o Projeto Escola e Museu e na ideia de experiência. Eu acho que esse trecho do John Dewey, "a arte como experiência" traduz o que é essa relação, da escola, do museu, da SME, da Extensividade, de todo esse projeto escola e museu.

... a experiência, na medida em que é experiência, consiste na acentuação da vitalidade. Em vez de significar um encerrar-se em sentimentos e sensações privados, significa uma troca ativa e alerta com o mundo; em seu auge, significa uma interpenetração completa entre o eu e o mundo dos objetos e acontecimentos... Por ser a realização de um organismo em suas lutas e conquistas em um mundo de coisas, a experiência é a arte em estado germinal. [John Dewey, "Arte Como Experiência", p. 83-84]

Eu acredito exatamente nisso, eu acredito que o Projeto Escola e Museu é exatamente isso, arte em estado germinal, muito obrigado.

\subsection{Avaliação realizada pelos docentes}

De acordo com a proposta do Projeto Escola e Museu, em 2015, vinte e duas unidades escolares participaram do circuito interativo nos sete equipamentos culturais parceiros da SME/RJ. Minimamente, vinte e dois professores estavam envolvidos diretamente com as ações. Deste total, dezoito docentes responderam ao questionário online disponibilizado pelo setor de Extensividade.

Quando questionados se o projeto havia agregado conhecimento ao trabalho, o grupo respondente foi unânime em afirmar que sim (gráfico 13). Tal fato constata o potencial do Projeto Escola e Museu como uma ferramenta para a formação docente em serviço. 
Gráfico 13: A participação no projeto agregou conhecimento ao seu trabalho?

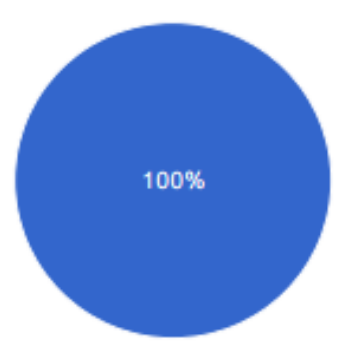

Sim $18 \quad 100 \%$

Não $\quad 0 \quad 0 \%$

Fonte: Extensividade (SME/RJ, 2015).

Durante as entrevistas, os docentes foram questionados se acreditavam ou não que o Projeto tivesse um caráter de formação docente e os professores apontaram aspectos positivos e negativos, como pode ser observado abaixo. De modo geral, os docentes participantes parecem ganhar "fôlego" ao sair da escola em direção à novas aprendizagem e oportunidades com os alunos, visto que exploram novos equipamentos culturais durante o horário de trabalho e que são distantes dos seus locais de atuação e/ou moradia.

Docente 15: É claro, tanto para a gente que é professor, a gente está aprendendo todo dia, coisas novas aparecem, quanto para eles também. A descoberta para eles é aprendizado para a gente também, a descoberta para eles é para gente a também o tempo todo. Coisas que a gente não tinha, parágrafos que a gente não leu no livro de história das artes e a gente tem aqui uma cena que fala de uma especificidade da lei contada por um imperador no período bizantino e isso é guardar mesmo e soma, soma bastante. (...) Como instrumento de formação cultural, permitindo com que os alunos e os próprios professores mesmo, se desloquem de áreas distantes do centro do Rio, que é onde tem o maior foco de cultura, apresentação de cultura é no Centro do Rio de Janeiro. Esse caminhar, essa jornada, eles vieram de Paciência, Zona Oeste, um pouco depois de Campo Grande, então, descoberta tanto até dos lugares por onde eles passam até o foco mesmo da cultura que se diz cultura mesmo para eles. (...) Estão acontecendo diversas coisas, diversas ideias para dentro de sala de aula. Coisas que eu não tinha pensado com relação à arte contemporânea, a liberdade de criação dos alunos está sendo de grande motivação pra mim, a história da arte, a gente pensa numa cronologia e a gente começa a trabalhar de outro ângulo para o contrário, ante cronológico e deixando que eles falem e que eles possam mexer nos materiais e criar coisas novas, isso é muito bom, muito muito bom mesmo.

Docente 8: Poderia melhorar. Eu acho que esses cursos poderiam ser dados por exemplo, para mim, o deslocamento até o centro do Rio para fazer uma formação é muito tranquilo, mas por exemplo, o meu colega que é da $10^{\mathrm{a}} \mathrm{CRE}$, de Santa Cruz, ele vai ter dificuldade de fazer esse projeto, então no mínimo em cada CRE deveria ser um polo de formação, para que esse projeto virasse uma formação docente. Nesse caso ele deixa muito a desejar, ele é uma formação boa para o discente e assim mesmo não dá para a gente atender a todos eles. O que a gente lá na escola 
põe para fazer é que eles passem o que eles aprendem aqui para os grupos mais novos que não puderam vir.

Docente 5: Cultura é sempre diversificada e quanto mais você puder diversificar, ter uma oportunidade até mesmo para eles e como eu que moramos longe. Até para nós professores que temos que estar sempre inseridos na cultura, mas que acaba sendo absorvido pelo trabalho, pelo local, pela carga horária, é uma oportunidade também de a gente estar se atualizando, estar se modernizando juntamente com os alunos. Acho que dentro das práticas docentes o sair, o visitar, libertar um pouquinho da sala de aula, das próprias paredes é sempre interessante, motivador, até que eles acabam aprendendo mais do que você ali nas quatro paredes e giz, então eu acho que é importante nesse sentido. Até tinha dito para a menina lá da recepção, porque eu não conhecia o Hélio Oiticica, apesar de conhecer a Praça Tiradentes, circular por alguns pontos da cidade. Não conhecia o espaço especificamente, então acaba você se perdendo em algumas instituições e centros que têm na cidade, até por conta do dia a dia, aquela coisa de você estar numa escola, vai correndo para outra. Então, quando a escola dá essa oportunidade eu acho que é legal para o aluno e para o professor também.

Quando os professores participantes e responsáveis em suas escolas pela execução do Projeto Escola e Museu foram questionados sobre a participação no circuito interativo em todos os equipamentos culturais com os seus respectivos alunos, apenas oito responderam que sim (gráfico 14). Como abordado no capítulo anterior, a jornada de trabalho docente é muito extensa e os professores não trabalham em regime de dedicação exclusiva para a SME/RJ, o que dificultou a participação integral dos professores responsáveis em suas escolas pelo Projeto Escola e Museu no circuito proposto.

Gráfico 14: Você participou de todo o circuito interativo com seus alunos(as)?

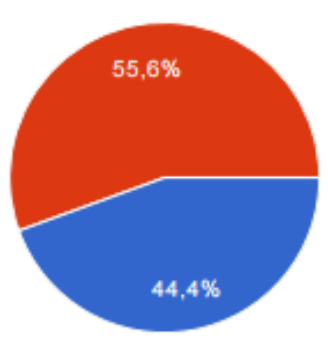

$\operatorname{Sim} 8 \quad 84.4 \%$

Não $10 \quad 55.6 \%$

Fonte: Extensividade (SME/RJ, 2015).

Com relação à recepção dos equipamentos culturais ao alunado, 50\% dos docentes respondeu que a Fundação Eva Klabin proporcionou o melhor acolhimento (gráfico 15). Através da observação das visitas escolares, foi possível constatar que o tempo de espera para o acolhimento dos alunos e docentes nas 
instituições era longo, mas a recepção realizada pela equipe da Fundação Eva Klabin era diferenciada, recebendo os alunos no jardim e oferecendo água, perguntando se fizeram uma boa viagem etc.

Gráfico 15: Qual museu e/ou centro cultural melhor recepcionou os alunos durante o circuito interativo?
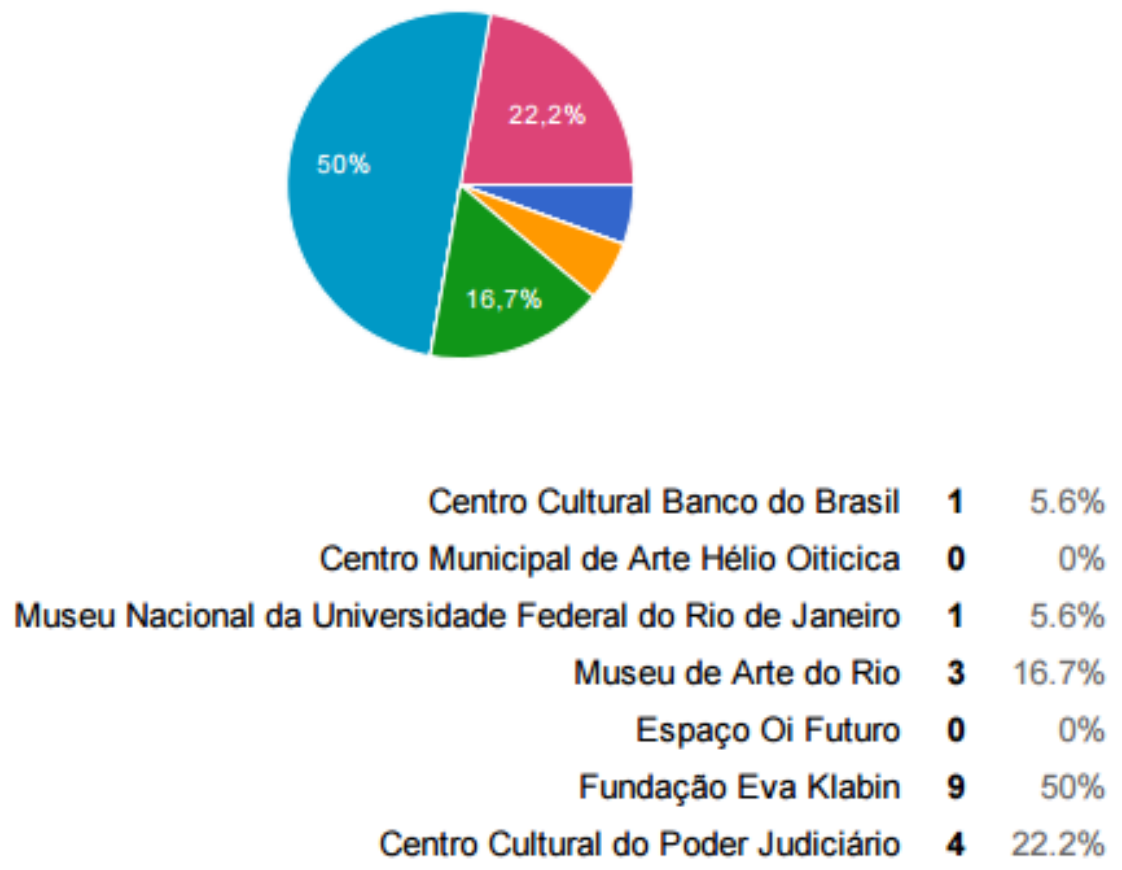

Fonte: Extensividade (SME/RJ, 2015).

$\mathrm{Na}$ questão sobre a dinamização das atividades com os alunos, 44,4\% dos docentes afirmaram que o CCPJ foi a instituição com o melhor desempenho nesse quesito (gráfico 16). A atividade era teatralizada, estratégia diferente quando comparada à ação dos outros equipamentos culturais. Além disso, no final, os alunos realizavam uma atividade prática trabalhando o conceito de justiça, apresentado de modo histórico através dos diferentes ambientes do CCPJ e dos diferentes papéis exercidos nos julgamentos que ocorrem no tribunal.

Essa constatação é particularmente interessante pois poderíamos esperar que a interação com a tecnologia fosse mais apreciada pelos jovens e pelos docentes; no entanto, a mediação ocorrida na interface entre pessoas fez mais diferença do que o contato com as ferramentas tecnológicas. Com a teatralização, os alunos eram convidados a dialogar e a refletir quando tinham eles mesmos que retratar cenas do cotidiano. De acordo com Flickinger (2014), para Gadamer 
O diálogo processa-se, de qualquer modo, só na medida em que cada um dos interlocutores aceita o desafio lançado pela pergunta do outro. Cada reação, por sua vez, torna-se novo desafio, de modo que o processo continua sem repouso o seu desdobramento(...). Parece óbvio o que se quer dizer quando se exige mútuo respeito entre os parceiros da comunicação. A questão é, no entanto, mais complexa, pois o reconhecimento do outro como interlocutor do diálogo gadameriano significa não apenas querer entender sua opinião. Importa mais ainda refleti-la, ou seja, tomá-la como espelho; pois nele a pessoa é lançada de volta a si mesma e obrigada a reavaliar suas convicções anteriores. O outro ou o interlocutor é o incentivo que nos faz refletir sobre nossa opinião atual. E o refletir na sua interpretação literal, significa aceitar o outro como o espelho que nos devolve a imagem de nós mesmos. (p. 84-85).

Gráfico 16: Qual museu e/ou centro cultural melhor dinamizou uma atividade com os alunos durante o circuito interativo?
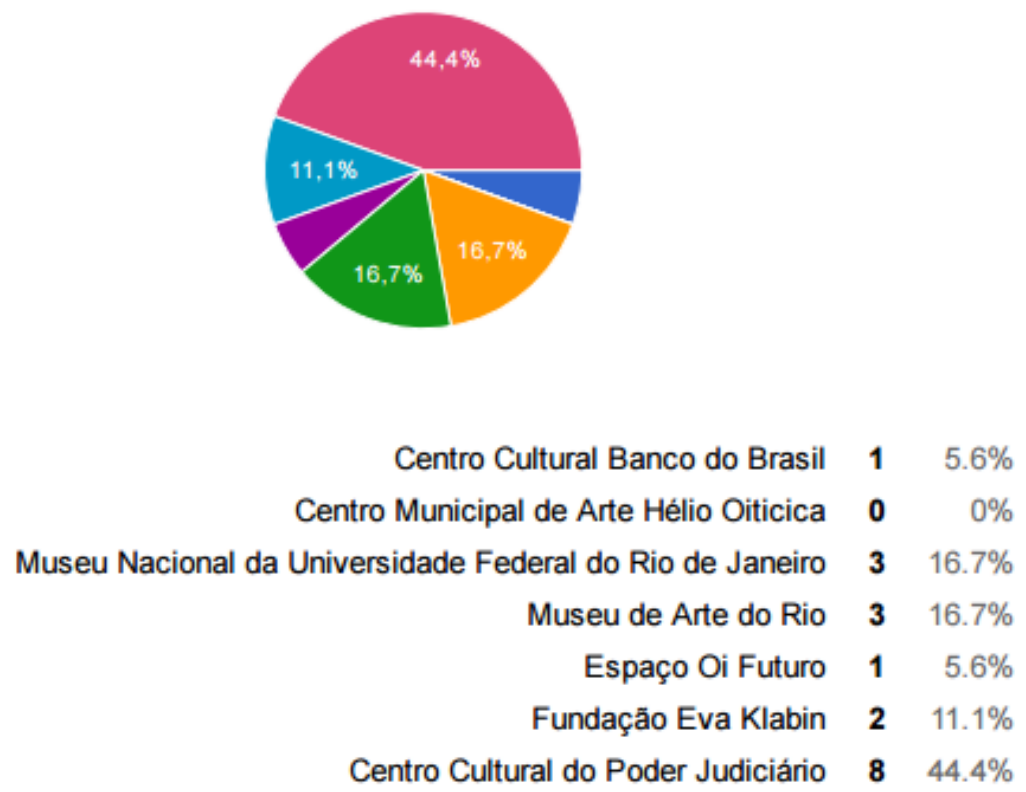

Fonte: Extensividade (SME/RJ, 2015).

Em seguida, os docentes deveriam atribuir graus de 1 a 7 para diversos itens relacionados ao atendimento oferecido pelos espaços de educação não formal: objetivos apresentados para a realização da atividade; recursos audiovisuais utilizados; materiais apresentados para o enriquecimento dos conteúdos; informações obtidas durante a realização da atividade; contribuição da atividade para a sua formação profissional; aplicabilidade dos conhecimentos adquiridos no ambiente de trabalho; produção de conhecimento para a melhoria da qualidade do ensino (gráficos 17, 18, 19, 20, 21, 22 e 23). Em quase todos os itens avaliados, a maioria dos docentes atribuiu graus entre 5 e 7 , demonstrando satisfação com a atividade desenvolvida pelos diferentes equipamentos culturais. 
No entanto, cabe ressaltar que não foi unânime a percepção por parte dos professores da aplicabilidade direta dos conhecimentos adquiridos no ambiente de trabalho e nem a produção de conhecimento para a melhoria da qualidade do ensino.

Gráfico 17: Objetivos apresentados para a realização da atividade.
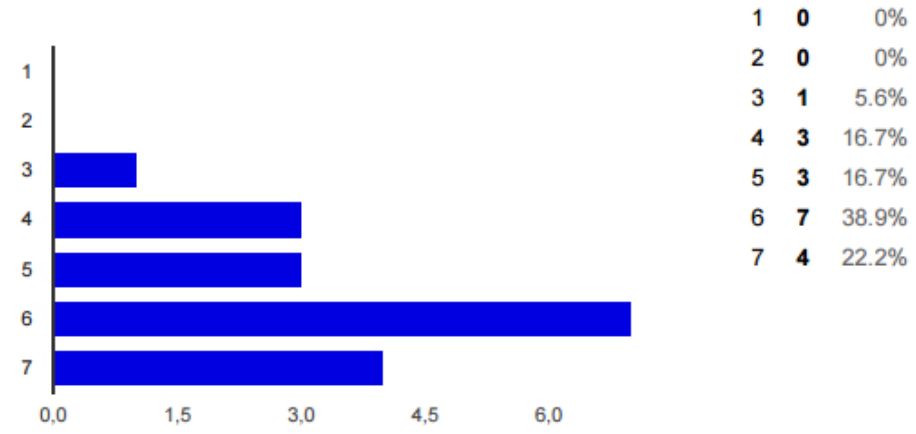

Fonte: Extensividade (SME/RJ, 2015).

Gráfico 18: Recursos audiovisuais utilizados

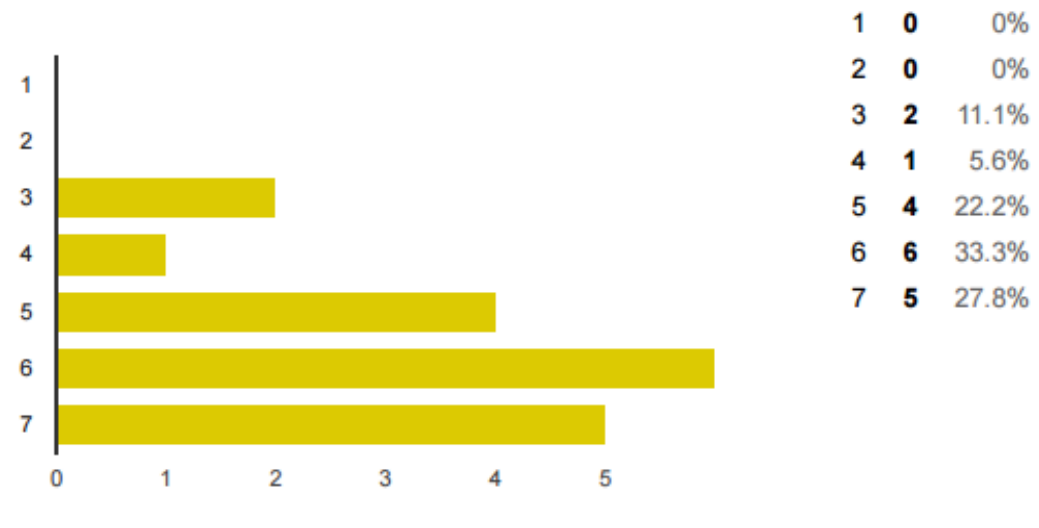

Fonte: Extensividade (SME/RJ, 2015).

Gráfico 19: Materiais apresentados para o enriquecimento dos conteúdos

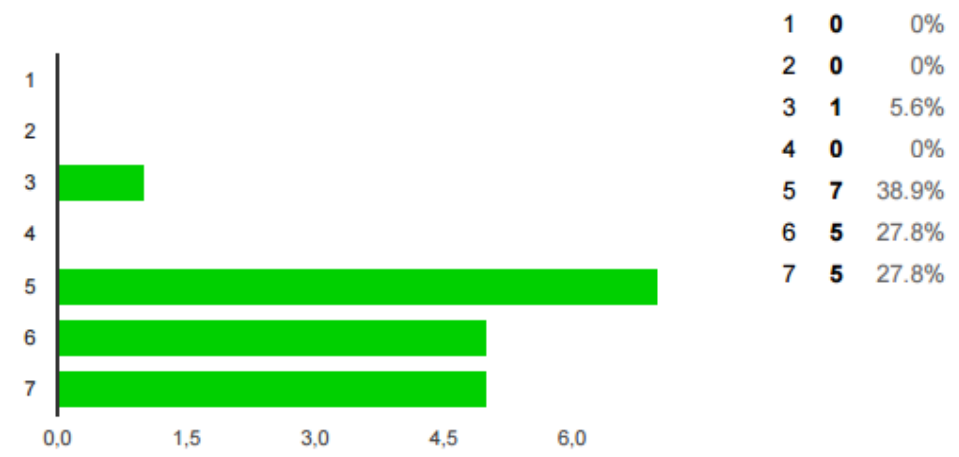

Fonte: Extensividade (SME/RJ, 2015). 
Gráfico 20: Informações obtidas durante a realização da atividade.

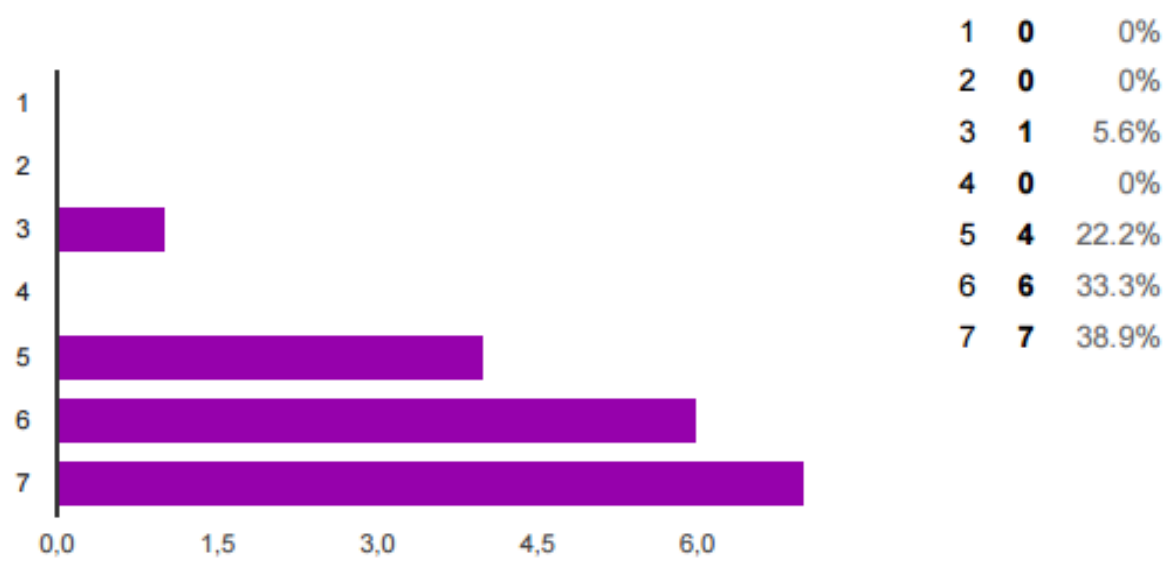

Fonte: Extensividade (SME/RJ, 2015).

Gráfico 21: Contribuição da atividade para a sua formação profissional.

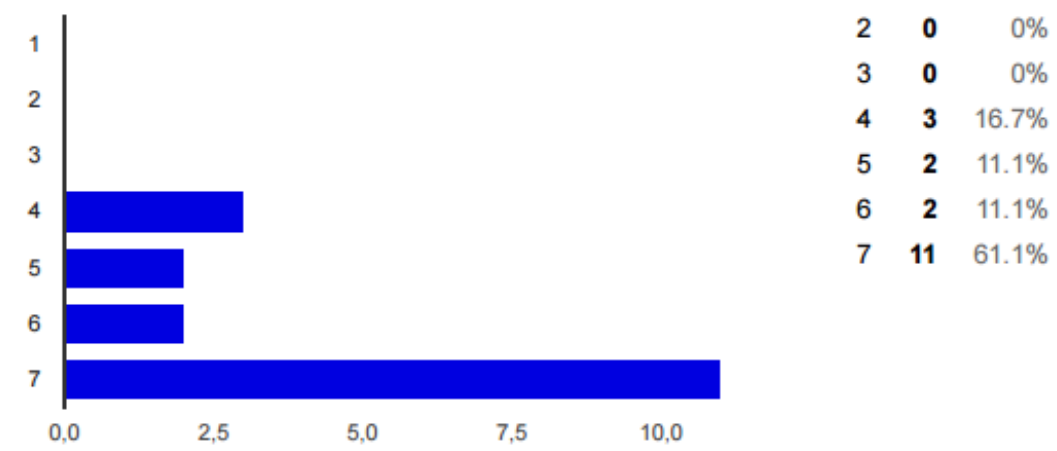

Fonte: Extensividade (SME/RJ, 2015).

Gráfico 22: Aplicabilidade dos conhecimentos adquiridos no ambiente de trabalho.

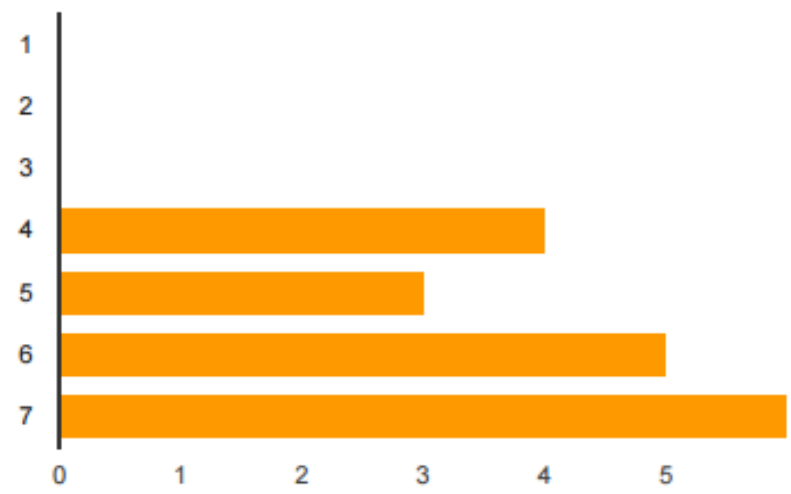

$\begin{array}{rrr}1 & \mathbf{0} & 0 \% \\ 2 & \mathbf{0} & 0 \% \\ 3 & \mathbf{0} & 0 \% \\ \mathbf{4} & \mathbf{4} & 22.2 \% \\ \mathbf{5} & \mathbf{3} & 16.7 \% \\ \mathbf{6} & \mathbf{5} & 27.8 \% \\ 7 & \mathbf{6} & 33.3 \%\end{array}$

Fonte: Extensividade (SME/RJ, 2015). 
Gráfico 23: Produção de conhecimento para a melhoria da qualidade do ensino

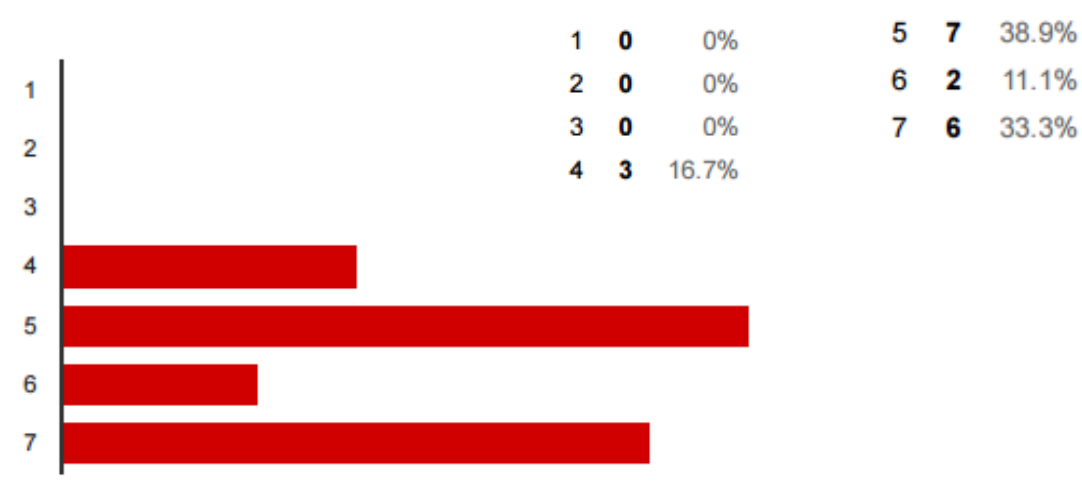

Fonte: Extensividade (SME/RJ, 2015).

O último item do questionário proposto aos professores era uma questão do tipo aberta, na qual os docentes deveriam indicar o que recomendariam para melhorar o Projeto Escola e Museu no futuro. Abaixo são apresentadas algumas indicações (quadro 2).

Quadro 2: O que você recomendaria para melhorar esse projeto no futuro?

A questão do transporte ficou bastante prejudicada.

Que os setores dos museus estivessem mais integrados com as escolas e educadores numa relação horizontal e sem distanciamento por parte principalmente dos museus. O MAR, por exemplo, é muito engessado, mas isso se deve a desastrosa gestão privada de espaços públicos. Fora O.S.

Que a continuidade da iniciativa no próximo ano letivo esteja garantida e que possa ser possível levar grupos diferentes de alunos, baseado na relação ano cursado/Museu a ser visitado.

Seria interessante uma interação maior entre professores e responsáveis pelo projeto nos museus. Esse diálogo seria importante para atender as especificidades de cada escola.

Além da formação do projeto, viabilizar esse espaço para troca de informações. Uma consulta aos alunos também seria interessante (o que pensam sobre museus, quais temas esperam encontrar... esse tipo de pergunta). Trazer o aluno para o protagonismo.

Empoderamento. Mais organização no que tange à realização das visitas. Minha escola teve muitos problemas e tivemos que fazer muitos passeios corridos. Alguns passeios ocorreram na semana da apresentação do seminário e um não aconteceu. Pensar em estratégias e abordagens que conectem a história local dos alunos (as experiências que traduzem diferentes espaços de vivências) com a história trazida pelos museus. A valorização da história e do lugar de onde vêm os alunos.

Maior participação da coordenação e direção da escola no projeto

Um quiz (perguntas com 3 opções) para os alunos fixarem os conteúdos, em forma de competição entre os meninos e meninas.

Recomendo a expansão do projeto, para que as escolas possam levar mais turmas nos mesmos museus em dias separados e também que se aumente o circuito de museus, 
podendo incluir museus como o Museu Histórico Nacional, Museu Aeroespacial (Sulacap), Cidade das Artes...

Adequação do horário à localização da escola, evitando retorno após o fim do turno da tarde.

Colocar um passeio por semana para podermos desenvolver o assunto da semana em sala de aula. Buscar outros espaços para visitas. Não necessariamente todas as escolas visitariam as mesmas instituições. Abrir outras possibilidades de reconhecimento através das premiações além da redação, como vídeos, atividade desenvolvida na escola a partir das visitas etc. Um processo de incentivo e otimização dos possíveis desdobramentos em sala de aula.

Assim como a Fundação Eva Klabin e o Espaço Oi Futuro, gostaria de ressaltar uma atividade artística após cada visita guiada sobre o conteúdo, para que os alunos pudessem levar com eles como recordação daquele momento e como um fazer artístico também, mas agradeço de igual modo a todos os espaços que nos receberam.

Desde o início, a garantia do transporte, pois as CREs prejudicaram o trabalho. E melhor comunicação projeto professor... Muitos e-mails que eram passados para a CRE e para a Escola não chegavam ao professor. Visto que minha escola entregou a redação fora do prazo, pois só recebemos a informação das datas quando já havia expirado o prazo. Do mais foi tudo um sucesso. A equipe da Extensividade e dos Museus estão de parabéns...Que esse projeto se perpetue por muito tempo. Mesclar as turmas, priorizando alunos que estivessem realmente interessados.

Melhoria na comunicação com todos os professores participantes, visto que algumas partes ficaram faltando para mim e para minha escola.

Fonte: Extensividade (SME/RJ, 2015).

Com a possibilidade de responder abertamente a última pergunta, os docentes apresentaram muitas questões relativas à execução do Projeto Escola e Museu. A primeira a ser destacada é o desejo de que os museus e centros culturais estivessem mais integrados à escola. De acordo com pesquisa realizada por KÖPTCKE (2003, p. 120),

Os professores sentem-se excluídos dos processos de concepção das atividades oferecidas aos seus alunos, consideram que a linguagem utilizada nem sempre é adequada ou que a abordagem privilegiada não interessa nem um pouco pelas experiências e expectativas do grupo visitante. Por outro lado, os animadores e mediadores culturais ignoram, algumas vezes, o nível de informação do público a quem se dirigem, consideram os professores incapazes de conduzirem com sucesso uma visita e costumam privilegiar uma postura de abertura e independência total no que se refere ao programa escolar e às atividades oferecidas nos museus.

Outro aspecto levantado pelos professores é o desejo de ampliação do projeto aos demais alunos. Como discutido no capítulo anterior, apenas uma turma do $8^{\circ}$ ano do ensino fundamental de cada escola selecionada poderia participar. No entanto, os professores ressaltaram o desejo de que outras séries e alunos de outras turmas do $8^{\circ}$ ano pudessem participar já que boas práticas deveriam ser ampliadas e distribuídas para um número maior de discentes. 
Um terceiro aspecto citado é que haja uma maior correlação entre o conteúdo trabalhado em cada ano escolar e o museu a ser visitado, demonstrando um possível interesse num uso escolarizado dos museus e centros culturais, objetivando reforçar a aprendizagem que acontece na sala de aula. Um dos docentes sugere a criação de um jogo de perguntas e respostas para a fixação do conteúdo trabalhado nos equipamentos culturais. Isto, de certa forma, evidencia uma menor preocupação com a formação cultural e maior ênfase na formação acadêmica conteudista. No entanto, como já apresentado no capítulo anterior, a formação cultural está relacionada ao cognitivo. Maria Margaret Lopes (1991, p.5) já destacava o anseio das escolas ao buscarem os museus, afirmando que,

na prática, o papel educacional que cabe aos museus, e há anos vem sendo debatido nos fóruns museológicos internacionais, reflete o fato de que a grande maioria do público que os frequenta é composta de crianças e jovens levados por suas escolas, para as tradicionais visitas guiadas, ou outras atividades que em essência vêm significando a transposição para o interior do museu das metodologias e práticas do ensino escolar. Chamamos escolarização a esse processo de incorporação pelos museus das finalidades e métodos do ensino escolar, cujas manifestações iniciais surgiram com os movimentos escolanovistas e vêm se aprofundando no bojo das propostas de educação permanente para museus.

Uma queixa relatada pelos docentes foi a falta de comunicação entre os diferentes níveis envolvidos no Projeto Escola e Museu: CREs, equipamentos culturais, escolas e professores. Em alguns momentos, a comunicação errônea (ou a falta) atrapalhou o andamento das atividades, impossibilitando que algumas escolas realizassem o roteiro nos sete museus e centros culturais propostos. Registraram, portanto, que é necessário haver mais planejamento e integração entre as diferentes instâncias que gerem e executam o projeto.

A questão da localização dos equipamentos culturais, já discutida no capítulo anterior, é retomada na avaliação dos professores. Um professor sugere a inclusão de museus localizados na Zona Oeste da cidade. A geografia dos roteiros precisa, sem dúvida, ser repensada pela equipe de extensividade para valorizar outros equipamentos culturais e permitir o maior fluxo de alunos pelas diferentes áreas do Rio de Janeiro. As escolas situadas longe do Centro da cidade chegavam aos espaços sempre relatando algo relacionado às dificuldades no deslocamento como, por exemplo, o trânsito.

Docente 18: O Parque de Madureira era o máximo que tinham ido, passar dali, saber que existe engarrafamento... (Durante a visita, ela havia comentado comigo que os alunos ficaram agoniados com a demora para 
chegar, perguntavam a todo momento se estavam chegando, se iria demorar muito, e ela dizia: 'É isso aí, gente, existe engarrafamento! - Trecho do caderno de campo, 2015).

Outro aspecto pontuado pelos docentes foi o tempo aligeirado para as visitas, em dois sentidos: muitas visitas numa mesma semana e pouco tempo dentro de cada equipamento cultural. Para Scheiner (2001, p. 2)

(...) toda exposição deveria ser 'saboreada' ponto a ponto, passo a passo, no tempo perceptual de cada indivíduo, possibilitando que todo o seu ser se impregnasse daquela experiência. É esta 'impregnação dos sentidos' que efetivamente mobiliza a emoção e desperta para a mudança.

Por fim, também precisa ser destacado o desejo que os alunos se configurem como os protagonistas das atividades. Um dos docentes aponta que seria interessante fazer uma sondagem com o grupo de adolescentes das escolas participantes para que sejam investigados os seus interesses, evidenciando a necessidade de um olhar educacional não mais para os adolescentes, mas com os adolescentes, a partir deles para que sejam autores na educação.

Através da avaliação realizada pelos professores, foi possível constatar que o Programa Escola e Museu apresenta muitos aspectos positivos, manifestado através do desejo de ampliação para mais turmas e séries. No entanto, fica evidente a necessidade de um replanejamento por parte do setor de Extensividade para solucionar que alguns impasses como, por exemplo, a questão do transporte, do deslocamento e da comunicação entre os diferentes níveis hierárquicos, de modo a obter maior sucesso na realização do projeto.

A seguir, são apresentados os dados relativos à avaliação realizada pelos adolescentes participantes do Projeto Escola e Museu.

\subsection{Avaliação realizada pelos alunos}

Como mencionado anteriormente, também foi disponibilizado um questionário online para os alunos. Antes de apresentar os resultados, cabe ressaltar que o universo de alunos participantes do Projeto Escola e Museu era de aproximadamente 920 , pois eram vinte três ${ }^{100}$ turmas participantes com uma média de 40 alunos em cada. No entanto, o número de alunos respondentes é bem

\footnotetext{
${ }^{100}$ Apesar de constar no PPT disponibilizado pela equipe do Setor de Extensividade que seriam vinte e duas escolas participantes em 2015, sendo duas pertencentes a cada CRE, na execução do Projeto Escola e Museu o total foi de vinte e três escolas, sendo que não havia participantes da $9^{\mathrm{a}} \mathrm{e}$ da $11^{\mathrm{a}}$ CREs.
} 
inferior, perfazendo um total de 49 e, em muitas escolas, nenhum dos alunos participantes respondeu a avaliação.

Dentre os respondentes, vinte são do sexo masculino e vinte e nove do sexo feminino (gráfico 24).

Gráfico 24: Sexo dos alunos respondentes.

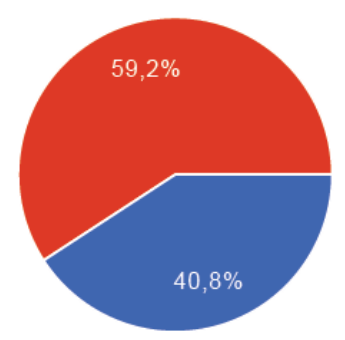

$$
\begin{array}{rrr}
\text { Masculino } & \mathbf{2 0} & 40.8 \% \\
\text { Feminino } & \mathbf{2 9} & 59.2 \%
\end{array}
$$

Fonte: Extensividade (SME/RJ, 2015).

Dentre as vinte e três escolas participantes, apenas alunos pertencentes a cinco escolas responderam ao questionário (tabela 11). O nome das escolas foi preservado e mantido em sigilo, constando apenas as CREs da qual fazem parte.

Tabela 11: Quantitativo de alunos que responderam a avaliação

\begin{tabular}{|c|c|c|}
\hline Escola & CRE & Quantitativo de alunos respondentes \\
\hline 1 & $10^{\mathrm{a}}$ & 30 \\
\hline 2 & $2^{\mathrm{a}}$ & 14 \\
\hline 3 & $7^{\mathrm{a}}$ & 3 \\
\hline 4 & $1^{\mathrm{a}}$ & 1 \\
\hline 5 & $2^{\mathrm{a}}$ & 1 \\
\hline Demais & & 0 \\
\hline Total & 5 & 49 \\
\hline
\end{tabular}

Fonte: Extensividade (SME/RJ, 2015).

No item seguinte os alunos eram convidados a declarar se haviam visitado algum museu ou centro cultural antes do Projeto Escola e Museu. Do universo de alunos respondentes, 59,2\% nunca havia frequentado um desses equipamentos culturais (gráfico 25). Os 40,8\% dos que responderam positivamente à questão, afirmaram conhecer muitos espaços pertencentes ao Projeto Escola e Museu. Esse 
fato gerou o questionamento sobre o entendimento da pergunta. Os alunos deveriam responder sobre equipamentos culturais que conheciam anteriormente ao projeto, mas vários falaram sobre as instituições pertencentes ao projeto (quadro 3).

Gráfico 25: Você já visitou museu ou centro cultural antes do projeto?

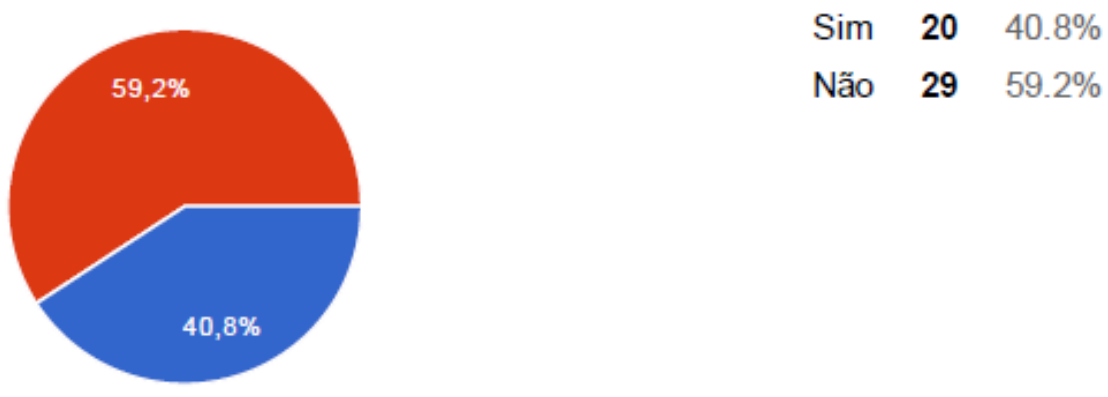

Fonte: Extensividade (SME/RJ, 2015).

Quadro 3: Em caso afirmativo, qual(quais) Museu(s) e Centro(s) Cultural(is) já foram visitados?

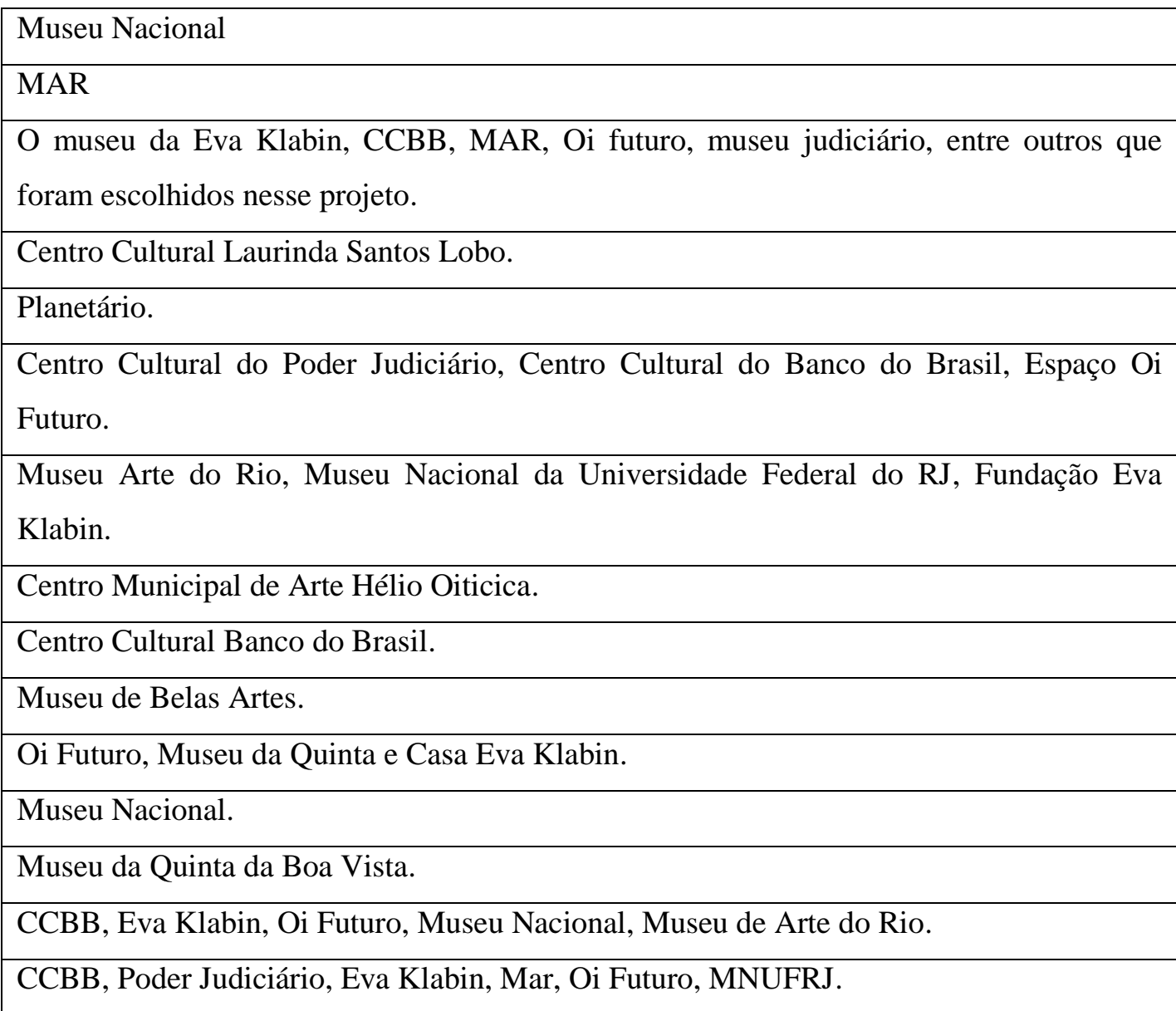


CCBB, Oi Futuro, Museu de Arte do Rio, MNUFRJ.

Casa da Princesa Isabel em Santa Cruz.

Banco do Brasil.

Não lembro.

Fonte: Extensividade (SME/RJ, 2015)

Os alunos deveriam esclarecer quem havia acompanhado nas visitas aos museus e/ou centros culturais anteriores ao Projeto Escola e Museu. Ficou evidente a participação e protagonismo da escola como promotora da ida dos alunos aos equipamentos culturais relatados (quadro 4).

Quadro 4: Com quem você fez a visita?

Com professores e alunos.

Escola.

Os alunos da minha turma e a professora.

Mestre João Kanoa (faço Capoeira).

Coordenadora Fernanda.

Com amigos do colégio e professores.

Família.

Com a outra escola.

Com a professora e os alunos da turma.

Com amigos.

Com professores e alunos.

Com familiares.

Com minha mãe.

Com a escola.

Com meus pais.

A escola.

Fonte: Extensividade (SME/RJ, 2015).

Ainda na tentativa de destacar o papel da escola como esfera que promove o acesso de crianças e jovens da rede pública aos equipamentos culturais, apresento dados da pesquisa "Projetos de mídia-educação nas escolas da Rede Pública Municipal do Rio de Janeiro e aprendizagem escolar", que foi uma 
iniciativa do Instituto Desiderata ${ }^{101}$, com o objetivo de conhecer mais sobre a realidade da mídia-educação nas escolas do Rio de Janeiro e, dessa forma, reunir elementos que subsidiem as políticas públicas educacionais. A pesquisa aconteceu em parceria com a (SME/RJ), através da Gerência de Mídia-educação e com o Grupo de Pesquisa Educação e Mídia ${ }^{102}$ (GRUPEM/PUC-Rio). O Objetivo geral da pesquisa foi o levantamento, categorização e análise de projetos de mídiaeducação e de práticas mídia-educativas nas escolas da rede pública municipal de ensino da cidade do Rio de Janeiro.

O estudo foi desenvolvido entre os anos de 2015 e 2016, contando com uma população de 1009 escolas que atendem ao segundo segmento do ensino fundamental. Por questões metodológicas, foram utilizados os questionários respondidos por 911 unidades escolares.

Um dos conceitos-chave do instrumento foi a questão da prática cultural, na qual foi pesquisada a frequência em que as atividades culturais são promovidas nas escolas, envolvendo 11 modalidades: mostra de festivais dentro e fora da escola; clube de leitura, círculo de leitores, roda de leitura e sarau dentro e fora da escola; idas a espetáculos de dança; ao cinema; a shows e espetáculos musicais; a museus e centros culturais; ao teatro; à Bienal do Livro, Salão do Livro e outros eventos literários; participação de concursos literários, musicais, audiovisuais, dança, teatro e circo (tabela 12).

Essa foi mais uma pesquisa que ressaltou a relevância das escolas em oportunizar o acesso dos alunos da rede pública municipal aos equipamentos culturais. Em média, 30\% das escolas da rede levam os estudantes a museus e centros culturais bimestral e semestralmente e, apenas, 6,1\% de um total de 911 escolas nunca leva os alunos a esses espaços de educação não formal. Segundo o relatório dessa pesquisa,

Em virtude da desigualdade social, no Brasil a escola é uma das principais instituições responsáveis pela construção e ampliação de práticas culturais junto às crianças e adolescentes. Atividades culturais realizadas dentro da escola ou atividades das quais os estudantes participem, fora da escola, com o apoio direto ou indireto da instituição escolar (como visitas a museus, feiras de livros, espetáculos

\footnotetext{
101 Organização social que atua no Rio de Janeiro com foco no segundo segmento do Ensino Fundamental.

102 Grupo de pesquisa vinculado ao Programa de Pós-graduação em Educação da PUC-Rio, coordenado pela professora Rosália Duarte, especialista em estudos sobre as relações que crianças, jovens e professores estabelecem com a mídia. O GRUPEM coordenou e executou a pesquisa.
} 
teatrais, cinema entre outras) criam um ambiente de valorização da cultura, proporcionam experiências de fruição e ampliam o repertório cultural dos alunos. Esse é também um dos objetivos de projetos de Mídia-educação. (Instituto Desiderata, 2017, p. $\left.36^{103}\right)$.

Tabela 12: Frequência em que são promovidas as atividades

\begin{tabular}{|c|c|c|c|c|c|}
\hline & ANUAL & SEMESTRAL & BIMESTRAL & MENSAL & NUNCA \\
\hline MOSTRAS E FESTIVAIS FORA DA ESCOLA & 29,8 & 25,6 & 14,4 & 3,7 & 26,5 \\
\hline MOSTRAS E FESTIVAIS DENTRO DA ESCOLA & 12,9 & 33,9 & 39,2 & 6,6 & 7,4 \\
\hline $\begin{array}{l}\text { CLUBES DE LEITURA, CÍRCULO DE LEITORES, } \\
\text { RODA DE LEITURA, SARAU FORA DA ESCOLA }\end{array}$ & 15,9 & 14,2 & 11,5 & 14,1 & 44,4 \\
\hline $\begin{array}{l}\text { CLUBES DE LEITURA, CÍRCULO DE LEITORES, } \\
\text { RODA DE LEITURA, SARAU DENTRO DA ESCOLA }\end{array}$ & 6,3 & 15,4 & 24,6 & 50,2 & 3,6 \\
\hline IR A ESPETÁCULOS DE DANÇA & 28 & 14,4 & 6,5 & 1,7 & 49,4 \\
\hline IR AO CINEMA & 28 & 19,4 & 6,9 & 1,6 & 44,1 \\
\hline IRA SHOWS E ESPETÁCULOS MUSICAIS & 21,8 & 13 & 5,7 & 1,7 & 57,7 \\
\hline IRA MUSEUS E CENTROS CULTURAIS & 23,6 & 30,9 & 30,9 & 8,5 & 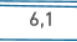 \\
\hline IR AO TEATRO & 26,6 & 19,7 & 9,7 & 2,3 & 41,7 \\
\hline $\begin{array}{r}\text { IR A BIENAL DO LIVRO, SALÃO DO LIVRO } \\
\text { E OUTROS EVENTOS LITERÁRIOS }\end{array}$ & 81,1 & 12,2 & 2,8 & 0,8 & 3,1 \\
\hline $\begin{array}{l}\text { PARTICIPAR DE CONCURSOS LITERÁRIOS, } \\
\text { MUSICAIS. AUDIOVISUAIS. DANCA. TEATRO. CIRCO }\end{array}$ & 42,7 & 17,1 & 9 & 2,3 & 29 \\
\hline
\end{tabular}

Fonte: Instituto Desiderata, 2017.

Dando continuidade à análise da avaliação realizada pelos alunos participantes do Projeto Escola e Museu, também foi perguntado se consideravam importante conhecer museus e centro culturais. A maior parte dos respondentes afirmou que sim (quadro 5). Nesse item, pode-se afirmar que o Projeto Escola e Museu cumpriu um de seus objetivos na perspectiva dos alunos: valorizar o patrimônio cultural da cidade.

Quadro 5: Você considera importante conhecer os Museus e Centros Culturais de sua cidade?

Sim.

Sim.

Não.

Sim!

Sim.

Sim sempre bom conhecer museus seja dele o que for.

Muito! É uma oportunidade enriquecedora para nós!

${ }^{103}$ PESQUISA PROJETOS DE MÍDIA-EDUCAÇÃO NAS ESCOLAS DA REDE PÚBLICA MUNICIPAL DO RIO DE JANEIRO E APRENDIZAGEM ESCOLAR - 2015/2016. Disponível em:http://www.desiderata.org.br/assets/apresenta\%C3\%A7\%C3\%A3o_resultados_pesquisamidiae du.pdf. Acesso em: 30 abr. 2017. 


\begin{tabular}{|l|}
\hline Bastante. \\
\hline Pra caramba. \\
\hline Sim. Pois assim posso aprender mais coisas sobre o país e a sua história! \\
\hline Sim, para conhecermos mais sobre a vida. \\
\hline Sim, pois só assim conheceremos realmente a nossa cidade. \\
\hline Considero, pena que não tenho muita chance de fazer isso. \\
\hline Sim, pois nos permite um aprendizado que não temos na escola. \\
\hline Completamente! \\
\hline Não \\
\hline Não muito. \\
\hline Mais ou menos \\
\hline Sim.
\end{tabular}

Fonte: Extensividade (SME/RJ, 2015).

Duas respostas merecem destaque: a vontade expressada em visitar mais equipamentos culturais e a diferenciação do aprendizado escolar do aprendizado que ocorre em museus e centros culturais. Isso ratifica a relação profícua que pode ser estabelecida entre a escola e os equipamentos culturais, para que o aluno tenha acesso a uma gama infinita de conhecimentos de diferentes formas. Segundo Rangel (2010, p.126),

Na contemporaneidade podemos observar um novo fenômeno de ressignificação e apropriação cultural do museu. Não estamos mais discutindo a democratização do acesso aos bens culturais presentes nas coleções museológicas ou o direito de acessar o capital cultural acumulado nestas instituições, mas sim a democratização do próprio museu, que passa a partir de agora a ser compreendido como uma ferramenta ou instrumento de trabalho que pode e deve ser utilizado por diferentes segmentos sociais.

A etapa seguinte questionava se o Projeto Escola e Museu atendeu as expectativas dos alunos participantes. A maior parte declarou que sim e, em alguns casos, a expectativa foi superada, além de despertar nos adolescentes o desejo de frequentar equipamentos culturais (quadro 6).

Quadro 6: O Projeto escola e Museu atendeu as suas expectativas?

$$
\text { Sim. }
$$$$
\text { Sim. }
$$ 


\begin{tabular}{|l|}
\hline Não. \\
\hline Sim!! \\
\hline Sim. \\
\hline Sim foi perfeito. \\
\hline Muito. \\
\hline Bastante. \\
\hline Demais. \\
\hline Sim, até demais. \\
\hline Atendeu completamente ao esperado. \\
\hline Superou o que eu esperava. \\
\hline Bastante. \\
\hline Atendeu completamente e espero poder continuar participando. \\
\hline Sim, pois eu nunca pensei que poderia ser legal ir a museus. \\
\hline Em parte. \\
\hline Um pouco. \\
\hline Sim. \\
\hline
\end{tabular}

Fonte: Extensividade (SME/RJ, 2015).

Os alunos participantes do Projeto Escola e Museu foram também questionados sobre a percepção do tema trabalhado nas diferentes instituições culturais parceiras da SME/RJ. Na percepção do grupo atendido em 2015, o tema mais abordado durante o circuito proposto pelo projeto foi a arte (gráfico 26).

Gráfico 26: Considerando os temais abaixo, assinale aqueles que, em sua percepção, foram abordados no Projeto.

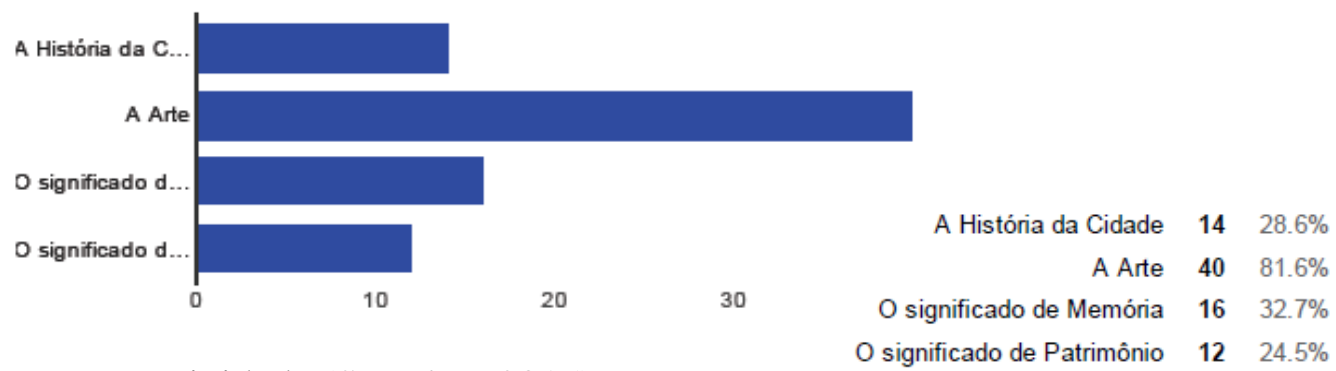

Fonte: Extensividade (SME/RJ, 2015).

Uma das etapas metodológicas do Projeto Escola e Museu é que cada escola participante indicaria uma turma do $8 .^{\circ}$ ano. Essa mesma turma participaria de um circuito interativo pelos sete equipamentos culturais já apresentados e teria 
o compromisso de socializar essa experiência por meio da elaboração de painéis, debates, exposições, materiais criativos entre outros, com os demais alunos da escola. Para verificar esta etapa, os alunos foram questionados quanto ao papel de multiplicadores e 57,1\% afirmaram que sim (gráfico 27).

Gráfico 27: Você se considera um multiplicador?

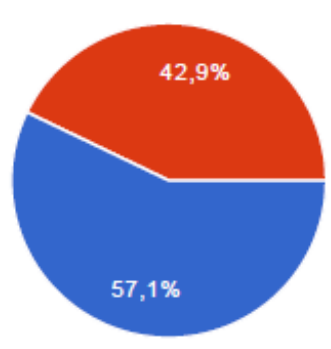

Fonte: Extensividade (SME/RJ, 2015).

O Projeto Escola e Museu tem como um dos objetivos formar público de visitação a instituições e espaços culturais, decorrente do desenvolvimento do interesse de alunos e professores pela apropriação de bens culturais. Em seguida, para verificar se os alunos tinham se tornado audiência espontânea, questionaram se eles já haviam retornado a algum museu e/ou centro cultural com familiares e amigos após o término do projeto. Mais uma vez fica evidente que, para os alunos que estudam na rede pública de ensino, a escola faz diferença no acesso aos equipamentos culturais, já que 95,9\% ainda não havia voltado a visitar um museu e/ou equipamento cultural (gráfico 28).

Gráfico 28: Você já retornou a algum museu e/ou centro cultural para visitar, com familiares ou amigos, depois que participou do Projeto?

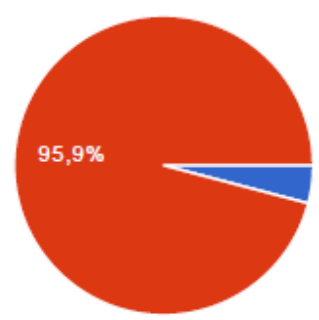

$\begin{array}{rrr}\text { Sim } & 2 & 4.1 \% \\ \text { Não } & \mathbf{4 7} & 95.9 \%\end{array}$

Fonte: Extensividade (SME/RJ, 2015). 
Os alunos também foram indagados sobre qual museu e/ou centro cultural havia provocado mais impacto. Dentre os sete equipamentos culturais visitados durante o circuito, o Espaço Oi Futuro $(24,5 \%)$ e o CCPJ $(22,4 \%)$ foram os mais votados (gráfico 29). Além disso, os alunos tiveram de justificar as escolhas e manifestaram diversas razões (quadro 7).

Gráfico 29: Qual museu e/ou centro cultural mais lhe impressionou durante o Projeto?
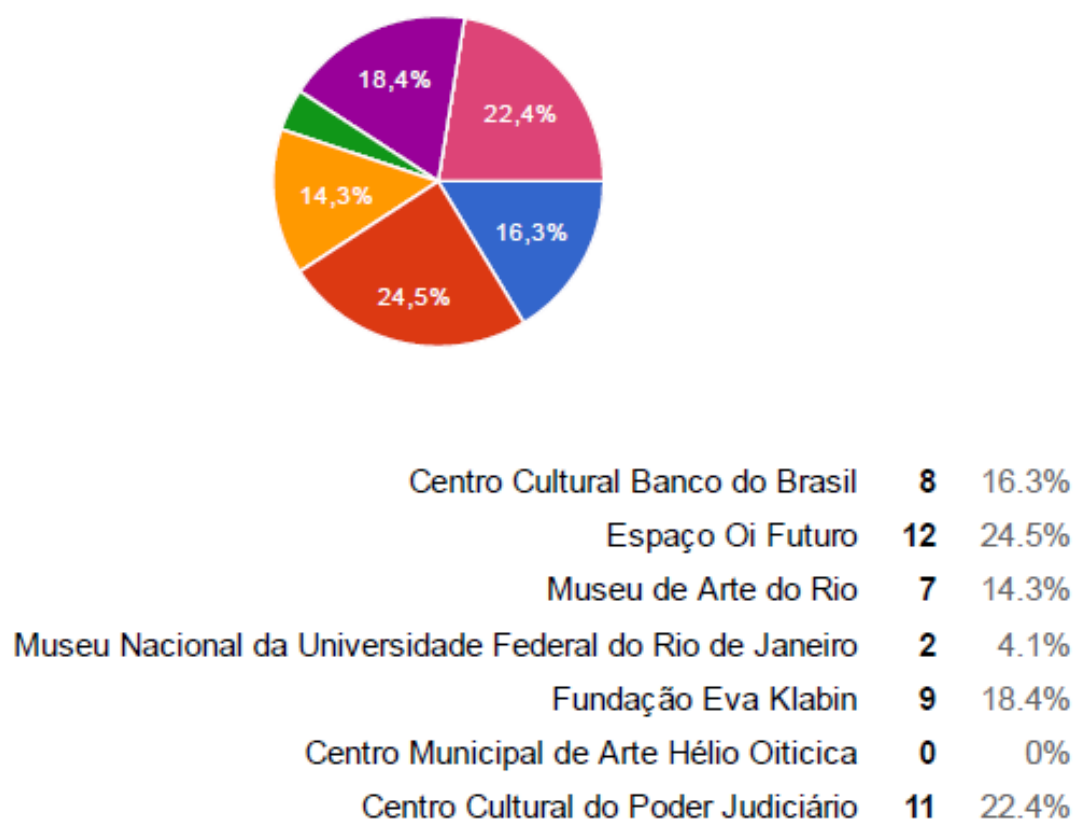

Fonte: Extensividade (SME/RJ, 2015).

Quadro 7: Justificativas para terem gostado de um determinado equipamento cultural pertencente ao Projeto Escola e Museu.

\begin{tabular}{|l|}
\hline Pela beleza. \\
\hline Gostei muito, pois eu pude conhecer como era a justiça antigamente! \\
\hline $\begin{array}{l}\text { Ah eu me impressionei mais no museu da Oi por causa que explica a história do telefone } \\
\text { tinha coisas que eu nunca tinha visto achei muito legal e interessante. }\end{array}$ \\
\hline $\begin{array}{l}\text { Gostei de saber sobre os tribunais e as leis. E o que mais adorei foi por que foi } \\
\text { teatralizado. }\end{array}$ \\
\hline O número de peças artísticas é elevado, variado e eclético. Tem arte para todos os gostos. \\
\hline A exposição das moedas. \\
\hline O guia era bem legal com a gente. \\
\hline O guia era maneiro.
\end{tabular}


Eu achei que esse me impressionou mais pois nele havia muitas coisas das quais eu gosto muito. E ver elas de perto, foi muito bom.

Tivemos várias atividades interativas, desenho na areia e etc.

Gostei da visita ter sido feita como uma peça de teatro, apesar de algumas meninas terem ficado com medo da atriz.

Gostei dos meteoritos e de podermos pegar nos bichos empalhados.

Foi o que melhor nos fez pensar o que é a arte.

Os guias foram muito atenciosos e nos fizeram realmente entender o que é arte, além de vermos uma casa completamente diferente das que já vimos.

Amei poder fazer desenhos e deixar eles expostos no museu.

Interessante conhecer a vida de alguém através da arte.

Porque foi um passeio mais livre.

Por causa da proximidade com os objetos.

Por causa do teatrinho.

Por causa da interatividade.

Por causa da história do local e da chance de visitar a Praça Mauá.

Pelo teatro que foi feito durante o passeio.

Por conhecer os dinheiros de outros países.

Por causa do teatro feito durante a visita.

Por causa dos vídeos.

As peças de lá me impressionaram.

Gostei de algumas peças e do espelho.

Achei diferente e muito interessante.

A beleza me impressionou.

Fiquei muito impressionado com o que vi.

Gostei muito de conhecer o museu.

As explicações que foram dadas.

A transformação da casa num museu e as peças raras.

Muitas peças bonitas e a transformação da casa em museu.

Achei muito bonito.

Gostei muito do lugar.

Foi legal a apresentadora caracterizada.

Foi o mais bonito.

Gostei da tecnologia.

Gostei da explicação

A deusa que apresentou. 


\begin{tabular}{|l|}
\hline A explicação que recebemos. \\
\hline A sala da tecnologia. \\
\hline É bonito. \\
\hline A apresentação. \\
\hline A sala das histórias. \\
\hline
\end{tabular}

Fonte: Extensividade (SME/RJ, 2015).

Os alunos destacam a atividade teatralizada como algo positivo. Muñoz (2007, p.4) afirma que visita didática teatralizada

Se trata de um tipo de visita dramatizada projetada para educar e transmitir conhecimento aos participantes, principalmente estudantes. Nela se identificam e são reforçados os principais centros de interesse dos alunos, incentivando a sua participação através de testes, jogos, etc ${ }^{104}$.

A visita teatralizada também é uma ferramenta no processo de democratização da cultura, através de outra linguagem, pode persuadir o público adolescente, a construir uma narrativa que busca a construção de uma identidade. De forma mais lúdica, os adolescentes podem ser envolvidos e se sentir parte daquele local, ampliando o desejo de retornar e o gosto pela cultura e pelos museus e centros culturais.

Ao longo do trabalho de campo e em vários trechos das avaliações foi possível perceber o encantamento com os equipamentos culturais. Os alunos registraram que foi interessante conhecer a vida de alguém através da arte, destacando, por exemplo, como foi diferente ver uma casa-museu. Cabe destacar o papel da imaginação na realização de alguns desses eventos. Para Scheiner (2001, p. 5)

a capacidade imaginativa coloca em ação permanente a memória, como instrumento de elaboração de experiências. É o oposto do hábito, que atribui valor à permanência. A infinita capacidade imaginante do ser humano desdobra-se em fluxo continuado, permitindo-nos apreender o real como poética e desenhar incontáveis percursos entre a mente e os sentidos, como verdadeiros 'sonhos de vôo' - que se iniciam na mente e percorrem todos os caminhos da memória, em busca do maravilhoso e do desconhecido.

\footnotetext{
104 No original: Se trata de un tipo de visita teatralizada destinada a educar y transmitir conocimientos a los participantes, principalmente escolares. En ella se identifican y se refuerzan los principales centros de interés de los alumnos, incentivando su participación a través de pruebas, juegos, etc.
} 


\subsection{Considerações finais}

Conforme sinalizado anteriormente, muito se discute acerca da dimensão da formação acadêmica na educação, aspecto de fato relevante no processo de formação dos sujeitos. No entanto, esta tese pretendeu analisar também a dimensão da formação cultural, igualmente importante, mas pouco explorada nas pesquisas.

Foram então abordados conceitos como o de cultura e educação não formal, em sua relação com a escola, apresentando documentos legais que ressaltam, garantem e asseguram o direito de acesso a bens culturais pelos sujeitos na busca por uma formação cultural.

Recortando para a cidade do Rio de Janeiro, foi apresentado o modo como a questão da formação cultural tem sido contemplada nos últimos anos pelas distintas gestões, focando no Projeto Escola e Museu - política pública adotada desde 2013 pelo governo municipal, em um contexto em que são utilizadas as avaliações externas e índices de desenvolvimento educacional, além do uso de políticas de responsabilização docentes.

Especialmente em 2014 e 2015, o critério de seleção das escolas que participariam do circuito cultural do Projeto Escola e Museu tinha por base o fato de terem baixo desempenho e/ou estarem localizadas em áreas conflagradas da cidade, configurando-se um bom uso das medidas de aprendizado para a tomada de decisões políticas, oportunizado a formação cultural para alunos lotados em escolas que precisam de apoio para o desenvolvimento de outras estratégias que possibilitem a melhoria da formação acadêmica.

Após análise da proposta do Projeto, do acompanhamento de vinte e seis visitas realizadas pelas escolas aos museus e centros culturais participantes e das entrevistas realizadas com vinte docentes, buscou-se verificar se a proposta possibilitava uma formação cultural de qualidade, a partir do conceito de formação proposto dor Gadamer e Dewey, voltada para a sensibilização estética, de modo crítico, na qual o aluno pudesse entender melhor a si mesmo e estabelecer novas relações com o mundo que o cerca.

$\mathrm{O}$ encontro com as obras de arte as interpelações propostas seriam, nessa perspectiva, uma oportunidade de construir novas aprendizagens éticas, estéticas e acadêmicas. Nesse processo, as experiências passadas são ativadas e reelaboradas 
a partir das experiências vivenciadas no momento das atividades propostas pelos sete equipamentos culturais. Dessa forma, pode-se concluir que o Projeto Escola e Museu configura-se uma política de formação cultural de qualidade e, ainda que tenha limitações, os alunos foram sensibilizados esteticamente através de ações que estimulavam a auto compreensão e o desenvolvimento de novas perspectivas sobre a realidade.

Ademais, foi possível constatar que o Projeto Escola e Museu é uma ação voltada para a equidade; amplia a formação cultural dos alunos; estimula a audiência espontânea; incita a aprendizagem prazerosa; não enfatiza a escolarização museal e promove a formação docente em serviço.

Por outro lado, o Projeto também apresenta aspectos que precisam ser melhorados e que foram apontados nos relatos dos docentes, tais como: oferta restrita aos alunos do $8^{\circ}$ ano; número reduzido de escolas participantes; concentração dos equipamentos culturais na zona sul e no centro da cidade; problemas relacionados ao transporte e ao deslocamento; o tempo aligeirado para o circuito ser realizado.

Também verificou-se que o grupo de professores participante da edição de 2015 do Projeto Escola e Museu se configurava como leitor ativo da construção de sentido dos "textos" da política emitida pela SME/RJ e, desta forma, reformulava e reescrevia os mesmos, decidindo, por vezes, desenvolver ações diferentes das que haviam sido propostas como, por exemplo, selecionar alunos de diferentes anos escolares para a realização do circuito cultural.

Ao longo do trabalho de campo e em vários trechos das avaliações foi possível perceber o encantamento dos alunos com os equipamentos culturais, com as descobertas de novas áreas da cidade, com a possibilidade de viverem novas experiências. Mais uma vez fica evidente que, para os alunos que estudam na rede pública de ensino, a escola faz diferença no acesso aos equipamentos culturais.

A mediação ocorrida na interface entre pessoas fez mais diferença do que o contato com a tecnologia, desconstruindo a ideia de que apenas ter as ferramentas tecnológicas é estratégia suficiente para que o jovem aprecie os museus e centros culturais. A qualidade da formação cultural, na perspectiva aqui defendida, ou seja, sensibilizar esteticamente de modo crítico os alunos, perpassou várias vezes pela forma como o acolhimento e a mediação eram realizados pelas equipes dos equipamentos culturais parceiros das SME/RJ. Quanto mais as 
equipes mediadoras conseguiam envolver os alunos de modo que se apropriassem dos espaços, mais eram interpelados/desafiados pelos artefatos das diferentes exposições e mais jogavam de acordo com a perspectiva gadameriana, desenvolvendo os sensos estéticos, éticos e cognitivos.

Não apenas alunos, docentes e instituições participantes do Projeto Escola e Museu foram beneficiados. Enquanto observava o circuito percorrido pelas diferentes unidades escolares, pude ter acesso a museus e centros culturais que não conhecia (FEK, CMAHO e CCPJ), fui exposta a uma diversidade de obras de arte, sendo questionada por elas e sensibilizada, construindo novos saberes e perspectivas.

Com relação à educação, o Brasil vive novamente tempos de mudanças curriculares. O MEC já divulgou a terceira versão da nova Base Nacional Comum Curricular (BNCC) e, em um esforço final de pesquisa, pensando nos tempos vindouros, encerro apresentando a perspectiva sobre a formação cultural proposta neste documento que orientará as ações educativas escolares em toda a Educação Básica e, em seguida, são tecidas breves considerações.

Ao longo do Ensino Fundamental - Anos Iniciais, a progressão do conhecimento ocorre pela consolidação das aprendizagens anteriores e pela ampliação das práticas de linguagem e da experiência estética e intercultural das crianças, considerando tanto seus interesses e expectativas quanto o que ainda precisam aprender. Ampliam-se a autonomia intelectual, a compreensão de normas e os interesses pela vida social, o que lhes possibilita lidar com sistemas mais amplos, que dizem respeito às relações dos sujeitos entre si, com a natureza, com a história, com a cultura, com as tecnologias e com o ambiente.

[...] Ao longo do Ensino.Fundamental.--Anos.Finais, os estudantes se deparam com desafios de maior complexidade, sobretudo devido à necessidade de se apropriarem das diferentes lógicas de organização dos conhecimentos relacionados às áreas. Tendo em vista essa maior especialização, é importante, nos vários componentes curriculares, retomar e ressignificar as aprendizagens do Ensino Fundamental - Anos Iniciais no contexto das diferentes áreas, visando ao aprofundamento e à ampliação de repertórios dos estudantes.

Nesse sentido, também é importante fortalecer a autonomia desses adolescentes, oferecendo-lhes condições e ferramentas para acessar e interagir criticamente com diferentes conhecimentos e fontes de informação.

[...] Há que se considerar, ainda, que a cultura digital tem promovido mudanças sociais significativas nas sociedades contemporâneas. Em decorrência do avanço e da multiplicação das tecnologias de informação e comunicação e do crescente acesso a elas pela maior disponibilidade de computadores, telefones celulares, tablets e afins, os estudantes estão dinamicamente inseridos nessa cultura, não somente como consumidores. Os jovens têm se engajado cada vez mais como protagonistas da cultura digital, envolvendo-se diretamente em novas formas de interação multimidiática e multimodal e de atuação social em rede, que se realizam de modo cada vez mais ágil. Por sua vez, essa cultura também apresenta forte apelo emocional e induz ao imediatismo de respostas e à efemeridade das informações, privilegiando análises superficiais e o uso de imagens e formas de expressão mais 
sintéticas, diferentes dos modos de dizer e argumentar característicos da vida escolar. (Brasil, 2017, p. 55,56 e 57)

O termo experiência estética e intercultural se faz presente de modo explícito no que diz respeito às diretrizes para o primeiro segmento do ensino fundamental. No entanto, na segunda etapa, fica evidente uma maior preocupação com os aspectos ligados à cultura digital e o respeito à cultura de cada indivíduo. Duas dimensões importantes, mas separadas pelas etapas do ensino fundamental. O essencial, nesse momento, é que todos os agentes envolvidos na esfera educacional percebam o quanto é importante que seja garantido o desenvolvimento do aluno em sua plenitude em todas as etapas de ensino e isto se estende à formação cultural.

É o caminho que possibilitará que os objetivos destacados na BNCC sejam alcançados: alunos com autonomia intelectual e com a compreensão de si e do outro, sendo protagonistas de um mundo que requer sensibilidade aliada à cognição para superar tantos desafios.

A BNCC indica pontos que deverão estar presentes, por ano de escolaridade, nas matrizes curriculares que serão (re)elaboradas pelas secretarias de educação municipais e estaduais e pelas redes privadas. É fundamental que durante esse processo os agentes envolvidos tenham em vista que a consciência, a cognição e a aprendizagem possuem dimensões estéticas. É defendido que o currículo e outras questões ligadas à formação dos alunos como, por exemplo, a avaliação, desafiem a contraposição entre formação estética e racionalidade que muitas vezes é praticada no cotidiano escolar. É preciso repensar o conceito de racionalidade. A questão da dimensão estética da sensibilidade é anterior a linguagem verbal, ou seja, tem raízes em uma sensibilidade pré-linguística do ser humano, antes de significarmos em símbolos a sensibilidade já está presente nos sentidos.

Apesar desta pesquisa enfatizar a importância das atividades em museus e centros culturais, valorizando o encontro com as obras de artes, entende-se que a estética faz parte da vida e não está restrita aos equipamentos culturais. Desta forma, tal pesquisa abre um caminho de investigação relativo a um tema central à formação humana - a dimensão estética -, que não está trabalhado suficientemente nas avaliações dos alunos, na formação dos alunos e nem na 
formação dos professores, bem como não está esgotado teoricamente no meio acadêmico.

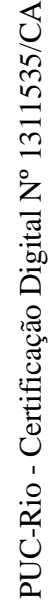




\subsection{Referências bibliográficas}

ADRIÃO, Theresa. \& GARCIA, Teise. Oferta educativa e responsabilização no PDE: o Plano de Ações Articuladas. Cadernos de Pesquisa. v. 38, n. 135, set./dez, 2008.

AFONSO, Almerindo J. Avaliação Educacional: Regulação e Emancipação. São Paulo: Cortez, 2002.

ALMEIDA, Andréa Baptista de. As políticas públicas de avaliação e a prática docente: percepções dos professores dos municípios do Rio de Janeiro e Duque de Caxias. 2013. 109 f. Dissertação (Mestrado) - Curso de Pós-graduação em Educação, Universidade Federal do Rio de Janeiro, Rio de Janeiro, 2013.

ALMEIDA E SILVA, Maria Juliana. A avaliação de sistemas de ensino no contexto da regulação das políticas.2008. Disponível em:http://www.simposioestadopoliticas.ufu.br/imagens/anais/pdf/DC02.pdf .Acesso em: 13 abr. 2015.

ALVES, Fatima. Políticas educacionais e desempenho escolar nas capitais brasileiras. Cadernos de Pesquisa. v. 38. n. 134, p. 413-440, maio/ago. 2008

ALVES, Fatima; LANGE, Wolfram \& BONAMINO, Alicia. A geografia objetiva de oportunidades educacionais da cidade do Rio de Janeiro. In: RIBEIRO, L. C. de Q. et al (Orgs.). Desigualdades urbanas, desigualdades escolares. Rio de Janeiro: Letra Capital, p. 67-89, 2010.

ALVES, Maria Teresa Gonzaga \& SOARES, José Francisco. Contexto escolar e indicadores educacionais: condições desiguais para a efetivação de uma política de avaliação educacional. Educação e Pesquisa. vol.39, n.1, pp. 177-194, 2013.

ANDRADE, Renato Júdice. Qualidade e equidade na educação básica brasileira: as evidências do SAEB 1995 - 2003. Tese (Doutorado em Educação), 230p. Belo Horizonte: Universidade Federal de Minas Gerais/ Faculdade de Educação, 2008.

ANDREWS, Christina. W. \& VRIES, Michiel. S. De. Pobreza e municipalização da educação: análise dos resultados do IDEB (20052009). Cadernos de Pesquisa. vol.42, n.147, pp. 826-847, 2012.

ARROYO, Miguel. Os educandos, seus direitos e o currículo. In: PRESIDÊNCIA DA REPÚBLICA. Ministério da Educação. Secretaria de Educação Básica. Departamento de Políticas de Educação Infantil e Ensino Fundamental. Indagações sobre currículo. Versão preliminar. Brasília, p. 51-81, 2006. 
AUGUSTO, Maria Helena. Regulação educativa e trabalho docente em Minas Gerais: a obrigação de resultados. Educação e Pesquisa. vol.38, n.3, pp. 695-709, 2012.

BALL, Stephen J. Diretrizes políticas globais e relações políticas locais em educação. Currículo Sem Fronteiras, v. 1, n. 2, p. 99-116, jul./dez. 2001.

Big policies/small world: an introduction to international perspectives in education policy. Comparative Education, Penn State, v. 34, n. 2, p. 119-130. 1998.

Educational reform: a critical and post-structural approach. Buckingham: Open University Press, 1994.

BALL, Stephen J.; BOWE, Richard. Subject departments and the "implementation" of National Curriculum policy: an overview of the issues. Journal of Curriculum Studies, London, v. 24, n. 2, p. 97-115, 1992.

BARBOSA, Andreza. Implicações dos baixos salários para o trabalho dos professores brasileiros. Revista Educação e Políticas em Debate, v. 1, n. 2, 2012.

BENJAMIN, Walter. Reflexões: a criança, o brinquedo, a educação. Tradução Marcus Vinicius Mazzari. São Paulo: Summus, 1984.

Magia e técnica, arte e política: ensaios sobre literatura e história da cultura. Tradução Sergio Paulo Rouanet. São Paulo: Brasiliense, 1994.

BONAMINO, Alicia. \& SOUZA, Sandra Zákia. Três gerações de avaliação da educação básica no Brasil: interfaces com o currículo da/na escola. Educação e Pesquisa. vol.38, n.2, pp. 373-388, 2012

BONDIA, Jorge Larrosa. Notas sobre a experiência e o saber da experiência. Revista Brasileira de Educação. Jan/ Fev/Mar/ Abr, n. 19, 2002.

BOTELHO, Isaura; FIORI, Maurício. O uso do tempo livre e as práticas culturais na região metropolitana de São Paulo. Relatório da primeira etapa da Pesquisa. São Paulo: Centro de Estudos da Metrópole CEBRAP, 2005.

BOWE, R.; BALL, S.; GOLD, A. Reforming education \& changing schools: case studies in policy sociology. London: Routledge, 1992.

BRANDÃO, Zaia. Pesquisa em Educação: conversas com pósgraduandos. Rio de Janeiro: Edições Loyola, 2001.

BRASIL. Ministério da Educação. Base Nacional Comum Curricular. Brasília: MEC, 2017. 
BRASIL. Indagações sobre currículo: currículo e avaliação / [FERNANDES, C. de O., FREITAS, L. C. ]; (orgs.) Jeanete Beauchamp, Sandra Denise Pagel, Aricélia Ribeiro do Nascimento. - Brasília: Ministério da Educação, Secretaria de Educação Básica, 44 p., 2007.

BRITO, Joaquim. Pais. DE. O museu, entre o que guarda e o que mostra. In: SEMEDO, A. e LOPES, J. T. Museus, Discursos e Representações. Porto: Edições Afrontamento, 2005.

BROOKE, Nigel. O futuro das políticas de responsabilização educacional no Brasil. Cadernos de Pesquisa. v. 36, n. 128, p. 377-401, maio/ago, 2006.

. Controvérsias sobre políticas de alto impacto. Cadernos de Pesquisa, v. 43, n. 148, p. 336-347, 2013.

CAMPBELL, Donald T.Assessing the impact of planned social change. 1976.

CAMPOS, Maria Malta. Educação infantil: 0 debate e a pesquisa. Cadernos de Pesquisa. v. 101, p. 113-27, 1997.

CARRASCO, M. R. \& TORRECILLA, F. J. M. A avaliação das aprendizagens na América Latina: Comportamentos e tendências do desempenho escolar dos estudantes latino-americanos nos ensinos primário e secundário. Sísifo - revista de ciências da educação, n.․․ 9 , Avaliação em Educação: Perspectivas Ibero-Americanas. Mai/Jun/Jul/Ago, 2009.

CARVALHO, Cristina. Quando a escola vai ao museu. 1a. ed. São Paulo: Papirus, 223p, 2016.

. "Criança menorzinha... Ninguém merece!": Políticas de infância em espaços culturais. IN: ROCHA, Eloisa e KRAMER, Sonia (orgs) Educação Infantil: Enfoques em diálogo. $3^{a}$. ed. Campinas, SP: Papirus, 2014.

Cultura: conceitos aplicados a espaços culturais. In: Musas Revista Brasileira de Museus e Museologia, № 4, 2009, p. 132-147.

O professor na visita a espaços museais: "tem hora que só atrapalha". Revista da FUNDARTE. Montenegro. ano 7, ㄲo 13 e ํㅜ 14, 2007, p. $76-82$.

. Espaços de cultura e formação de professores /monitores. In: LEITE, M. I.; OSTETTO, L. E. (Orgs). Museu, educação e cultura: Encontros de crianças e professores com a arte. Campinas/SP: Papirus, p. 117-139, 2005. 
CARVALHO, Cristina e PORTO, Cristina. Crianças em museus e centros culturais. In: KRAMER, S., NUNES, F. e CARVALHO, C. Educação Infantil: formação e responsabilidade. Campinas/SP: Papirus, 2013.

CAZELLI, Sibele. Jovens e escolas: quais os efeitos dos diferentes capitais no acesso a museus? In: RIBEIRO, L. C. de Q. et al (Orgs.). Desigualdades urbanas, desigualdades escolares. Rio de Janeiro: Letra Capital, p. 175-216, 2010.

Ciência, Cultura, Museus, Jovens e escola: quais as relações. 2005. In: www.observatoriodasmetropoles.ufri.br/download/Tese Sibele_05.pdf

CAZELLI, Sibele; COIMBRA, Carlos Alberto Quadros. Proposta para a avaliação da prática pedagógica de professores. Ensino Em Re-Vista, Uberlândia, v. 20, n.1, p.133-148, jan./jun. 2013.

COELHO, TEIXEIRA. Dicionário crítico de políticas culturais: Cultura e imaginário. 3 ed. São Paulo : FAPESP; lluminuras, 2004.

COIMBRA, Carlos Alberto Quadros; CAZELLI, Sibele; FALCÃO, Douglas; VALENTE, Maria Esther. Tipos de audiência segundo a autonomia sociocultural e sua utilidade em Projetos de divulgação. Revista Tempo Brasileiro, Rio de Janeiro, jan./mar., n. 188, p. 113-124, 2012.

COOMBS, Philip. Hall. La crisis mundial de la educación. Perspectivas actuales. Madri: Santillana, Col. Aula XXI, 1985.

COSTA, Antônio Gomes da. Os "explicadores" devem explicar? In: Diálogos \& ciência: mediação em museus e centros de Ciência. Orgs. Luisa Massarani, Matteo Merzagora, Paola Rodari. Rio de Janeiro: Museu da Vida/ Casa de Oswaldo Cruz/Fiocruz, 2007.

COUTINHO, Rejane Galvão. A formação de educadores como mediadores culturais. In: II Simpósio Internacional 'Estratégias do Ensino da Arte Contemporânea em Museus e Instituições Culturais'. Espaços da Mediação: A Arte e seus Públicos. São Paulo: Museu de Arte Contemporânea da Universidade de São Paulo. v. 1. p. 151-165, 2013.

DA MATTA, Roberto. Você tem cultura? Jornal da Embratel, Rio de Janeiro, 1981.

Ofício do etnólogo ou como ter anthropological blues. In: NUNES, E. (org). A aventura sociológica. RJ: Zahar, 1978.

DAYRELL, Juarez Tarcísio; GOMES, Nilma Lino. A juventude no Brasil. Observatório da juventude, v. 18, 2009.

DE FREITAS, Dirce Nei Teixeira. Avaliação da educação básica e ação 
normativa federal. Cadernos de Pesquisa. vol. 34 , n. 123 , p. 663-689, set./dez., 2004.

DEWEY, J. Experiência e Educação. Petrópolis/RJ: Ed. Vozes, 2010.

Arte como Experiência. Tradução Vera Ribeiro. São Paulo: Martins Fontes, 2010.

DOURADO, Luiz Fernandes e OLIVEIRA, João Ferreira de. A Qualidade da Educação: Perspectivas e Desafios. Caderno Cedes, Campinas vol. 29, n. 78, p. 201-215, maio/ago. 2009.

DUARTE, Rosália. Entrevistas em pesquisas qualitativas. Curitiba, Educar em Revista. v. 24, pp. 213-225, 2004.

ESQUINSANI, Rosimar Serena Siqueira e ESQUINSANI, Valdocir Antônio. A Língua Portuguesa como objeto de avaliações em larga escala: interpretações da mídia. SIGNUM: Estudos da Linguagem., Londrina, n. 15/2, p. 153-171, 2012.

ESQUINSANI, Rosimar Serena Siqueira. Performatividade e educação: a política das avaliações em larga escala e a apropriação da mídia. Práxis Educativa, Ponta Grossa, v.5, n.2, p. 131-137, jul.-dez. 2010.

Estatuto de Museus. CONSELHO INTERNACIONAL DOS MUSEUSICOM, 2004.

FERNANDES, Reynaldo e GREMAUD, Amaury. Qualidade da educação: avaliação, indicadores e meta. In: VELOSO, F. et al. (Orgs.). Educação básica no Brasil: construindo o país do futuro. Rio de Janeiro: Elsevier, p. 213-238, 2009.

FLICKINGER, Hans-Gerg. Gadamer e a Educação. Belo Horizonte: Autêntica Editora, 2014.

- Da experiência da arte à hermenêutica filosófica. In: ALMEIDA, C. L. S. de; FLICKINGER, H. G.; ROHDEN, L. Hermenêutica filosófica: nas trilhas de Hans-Georg Gadamer. Porto Alegre: EDIPUCRS, p. 27-52, 2000.

Freinet, Célestin. As técnicas de Freinet da escola moderna. Trad. Silva Letra. 4. ed. Lisboa, Portugal: Estampa. 1975.

FREITAS, Luiz Carlos de. Políticas de responsabilização: entre a falta de evidência e a ética. Cadernos de Pesquisa. [online]. vol.43, n.148, pp. 348-365, 2013.

. Os reformadores empresariais da educação: da desmoralização do magistério à destruição do sistema público de educação. Educação e Sociedade. vol.33, n.119, pp. 379-404, 2012. 
GADAMER, HANS-GEORG. Verdade e método I: traços fundamentais de uma hermenêutica filosófica. 7. ed., Petrópolis: Vozes; São Paulo: Editora Universitária São Francisco, 2005.

Hermeneutik II Wahrheit und Methode: Ergänzungen, Register. In: GADAMER, H. G. Gesammelte Werke. Tübingen: Mohr Siebeck, vol. 2, 1993.

GAMEIRO, Beatriz F. C. de Souza. Refletindo sobre a relação de professores, crianças e museus. Monografia. (Curso de Especialização em Educação Infantil) - Pontifícia Universidade Católica-Rio, Rio de Janeiro, 2011.

GARCÍA CANCLINI, N. Culturas híbridas. São Paulo: EDUSP, 2000.

GASPARIN, Marinez e SOLIGO, Valdecir. As avaliações em larga escala e a imprensa: resultados, regulação e os princípios e quase mercado. In: 5 Seminário Nacional Estado e Políticas Sociais. Cascavel: Edunioeste, vol. 1. p. 1-12, 2011.

GEERTZ, Clifford. Os usos da diversidade. Horiz. antropol., Porto Alegre, v. 5, n. 10, p. 13-34, mai. 1999.

GHANEM, Elie. Educação formal e não formal: do sistema escolar ao sistema educacional. In: TRILLA, JAUME et al (org). Educação formal e não formal: pontos e contrapontos. São Paulo: Summus, 2008.

GRINSPUM, Denise; Secretaria de Estado de Cultura de Minas Gerais Superintendência de Museus e Artes Visuais; Coleção Falando de Ações Educativas, № 4; Belo Horizonte / 04/ 2011.

- Educação para o Patrimônio: Museu e escola Responsabilidade compartilhada na formação de públicos. São Paulo: s.n., 2000. Tese de doutorado - Faculdade de Educação/Universidade de São Paulo.

HABERMAS, Jurgen. Modernidade - um projeto inacabado. In: ARANTES, O.; ARANTES, P. Um ponto cego no projeto moderno de Jünger Habermas. São Paulo: Brasiliense, 1992.

HALL, Stuart (ed.). Introduction. In: Representation: cultural representations and signifying practices. London: Sage Publications, 1997.

HANUSHECK, Eric e RAYMOND, Margaret. Does school accountability lead to improved student performance? NBER Working Paper 10591. Cambridge, MA: National Bureau of Economic Research Inc, 2004. 
HERMANN, Najda. Autocriação e horizonte comum: ensaios sobre educação ético-estética. ljuí. Editora Unijuí, 176p., 2010.

Ética e estética: a relação quase esquecida. Porto Alegre: EDIPUCRS, 2005.

HOOPER-GREENHILL, Eilean. Museum languages: objects and texts. 1991.

INGRAM, Debra: LOUIS, Karen; SCHROEDER, Roger. Accountability policies and teacher decision making: barriers to the use of data to improve practice. Teachers College Record. Volume 106 Number 6, 2004, pág. 1258-1287. Disponível em http://www.tcrecord.org. Acesso em: 14 jan. 2013.

JACOB, Brian. Accountability, incentives and behavior: The impact of high-stakes testing in the Chicago public schools. Journal of Public Economics, v.89, n.5-6, p. 761-796, 2005.

KISIEL, James. Understanding Elementary Teacher Motivations for Science Fieldtrip. Science Education, 89, pp. 936-955, 2005.

KLEIN, Ruben. Como está a educação no Brasil? O que fazer?. Ensaio: aval.pol.públ.Educ., Rio de Janeiro, v. 14, n. 51, Jun, 2006.

KÖPTCKE, Luciana Sepúlveda. A análise da parceria museu-escola como experiência social e espaço de afirmação do sujeito. In: GOUVÊA, G., MARANDINO, M. e LEAL, M. C. Educação e Museu - A construção social do caráter educativo dos museus de ciências. Rio de Janeiro: Access, 2003.

KÖPTCKE, Luciana Sepúlveda; PEREIRA, Marcele Regina Nogueira. Museus e seus arquivos: em busca de fontes para estudar os públicos. História, Ciências, Saúde - Manguinhos, Rio de Janeiro, v.17, n.3, jul.-set., p.809-828, 2010.

KRAMER, Sonia e CARVALHO, Carvalho. Dentro e fora do museu: de ser contemplador, colecionador, mediador. In: SANCHES, J.; ALMEIDA, R. \& FERREIRA-SANTOS, M. (Orgs.). Artes, museu e educação. $1^{\text {à }}$ ed. Curitiba: CRV, p.25-34, 2012.

KRAMER, Sonia. Infância, cultura contemporânea e educação contra a barbárie. In: Seminário Internacional Organização Mundial para a Educação Pré-escolar. Infância - Educação Infantil: reflexões para o início do século. Rio de Janeiro: Ravil, 2000.

LAGO, Clenio. Experiência estética e formação: articulação a partir da Hans-Georg Gadamer. EDIPUCRS, 2014. 
LOPES, Alice Casimiro. Política de currículo: recontextualização e hibridismo. Currículo sem fronteiras, v. 6, n.2, p. 33-52, jul./dez. 2005.

LOPES, João Teixeira. Notas conclusivas: Os museus como terceiras culturas. In: SEMEDO, A. e LOPES, J. T. Museus, Discursos e Representações. Porto: Edições Afrontamento, 2005.

LOPES, Ana Elisabete. Artes visuais e os diferentes modos de ver .In: JOBIM, Solange (org.) Educação@ pós-modernidade: Ficções científicas \& Crônicas do cotidiano. Rio de Janeiro: 7letras, 2003.

LOPES, Maria Margaret. A favor da desescolarização dos museus. Educação e sociedade, v. 40, p. 443-455, 1991.

MAILLARD, Chantal. La razón estética. Barcelona: Editorial Lartes, 1998.

MAINARDES, Jefferson. Abordagem do ciclo de políticas: uma contribuição para a análise de políticas educacionais. Educação e Sociedade, Campinas, v. 27, n. 94, p.47-69, 2006. Disponível em: <http://www.cedes.unicamp.br>. Acesso em: 16 mai. 2010.

MAINARDES, Jefferson; MARCONDES, Maria Inês. Entrevista com Stephen J. Ball: um diálogo sobre justiça social, pesquisa e política educacional. Educação e Sociedade, Campinas, vol. 30, n. 106, p. 303318, jan. /abr.2009.

MARANDINO, Martha. Interfaces na relação Museu- Escola. Cad.Cat.Ens.Fís., v. 18, n.1: p.85-100, abr. 2001.

MAROY, Christian. \& VOISIN, Annelise. As transformações recentes das políticas de accountability na educação: desafios e incidências das ferramentas de ação pública. Educação e Sociedade, Campinas, v. 34, n. 124, p. 881-901, 2013.

MARTINS, Mirian C.; PICOSQUE, Gisa; GUERRA, M. Terezinha Telles. Didática do ensino de arte: a língua do mundo: poetizar, fruir e conhecer arte. São Paulo: FTD, 1998.

MEDEIROS, Maria Beatriz. Aisthesis. Estética, educação e comunidades. Chapecó: Argos, 2005.

MESQUITA, Silvana. Os resultados do Ideb no cotidiano escolar. Ensaio: Avaliação e Políticas Públicas em Educação. vol.20, n.76, pp. 587-606, 2012.

MULTIRIO. Centro de Informações Multieducação. Disponível em: http://p ortalmultirio.rio.rj.gov.br/cime. Acesso em: 16 de julho de 2011. 
MUÑOZ, Francisco Javier Benitez. Reflexiones em torno a la animación del patrimônio. In: Boletín de interpretacíon. España, n. 17, p.3-5, oct 2007.

NASCIMENTO, Silvania Sousa do. O desafio de construção de uma nova prática educativa para os museus. In: FIGUEIREDO, Betânia G.; VIDAL, Diana G. (orgs.) Museus: dos gabinetes de curiosidades à museologia moderna. Belo Horizonte: Argvmentvm, p. 221-239, 2005.

NASCIMENTO JR., José do; CHAGAS, Mário; Museus e política: apontamentos de uma cartografia. In: Caderno de diretrizes museológicas. Brasília: Iphan, 2006. p.13-17.

NÓVOA, António. Desafios de trabalho do professor no mundo contemporâneo. Palestra ministrada no Sindicato dos professores de São Paulo em outubro de 2006. Disponível em: http://www.sinpro.org.br/arquivos/novoa/livreto_novoa.pdf. Acesso em: 2 mar. 2017.

OLEIRO, M. B. Apresentação. In: SEMEDO, A. e LOPES, J. T. Museus, Discursos e Representações. Porto: Edições Afrontamento, 2005.

OLIVEIRA, Romualdo Portela de e ARAUJO, Gilda Cardoso de. Qualidade do ensino: uma nova dimensão da luta pelo direito à educação. Rev. Bras. Educ., Rio de Janeiro, n. 28, abril 2005.

PEREIRA, Júnia Sales; SIMAN, Lana Mara de Castro; COSTA, Carina Martins; NASCIMENTO, Silvania Sousa de. Escola e Museu Diálogos e Práticas. Belo Horizonte: Secretaria de Estado de Cultura/Superintendência de Museus; Pontifícia Universidade Católica de Minas Gerais/Cefor, 2007.

PEREIRA, Talita Vidal, \& SEIXAS, Luciana Velloso da Silva. Um salto para a performatividade: sentidos atribuídos à qualidade da educação. Ensaio: Avaliação e Políticas Públicas em Educação. 20.74 (2012): 73-88.

PIPOLO, D. S. M. Círculos de avaliação: Uma forma de dialogar com os resultados educacionais. Revistalbero-americana de Educação, ก.ำ 53/3, jul, 2010.

RANGEL, Márcio. Políticas públicas e museus no Brasil. In: GRANATO, M; SANTOS, C. P.; LOUREIRO, M. L. N. M. O caráter político dos museus. MAST Colloquia, v.12, 138 p. Rio de Janeiro: MAST, 2010.

RIBEIRO, Maria das Graças; FRUCCHI, Graciela. Mediação - a linguagem humana dos museus. In: MASSARANI, L.; MERZAGORA, M.; RODARI, P. (Org.) Diálogos e ciência: mediação em museus e centros de ciências. Rio de Janeiro: Museu da Vida/ Casa de Oswaldo Cruz/ Fiocruz, p. 67-74, 2007. 
RIBEIRO, Luiz Cesar de Queiroz. \& KOSLINSKI, Mariane. A metropolização da questão social e as desigualdades de oportunidades educacionais no Brasil. In: RIBEIRO, L. C. de Q. et al (Orgs.). Desigualdades urbanas, desigualdades escolares. Rio de Janeiro: Letra Capital, p. 33-66, 2010.

RIO DE JANEIRO (RJ). Secretaria Municipal de Educação. Projeto Salto de Qualidade na Educação Carioca. Rio de Janeiro, 2009. Disponível em: <http://www.rio.rj.gov.br/web/sme>. Acesso em: 14 jul. 2012.

SANTOS, Maria Célia Teixeira Moura. Museus e Educação: conceitos e métodos. In: Cienkt, Porto Alegre, n. 31, jan/jun, 2002, p. 311,312.

SCHEINER, Tereza. "Comunicação, Educação e Exposição: novos saberes, novos sentidos", Semiosfera, Rio de Janeiro, no. 4-5, 2001.

SECRETARIA MUNICIPAL DE EDUCAÇÃO DO RIO DE JANEIRO. Multie ducaçao - Núcleo Curricular Básico. Rio de Janeiro, 1996.

SECRETARIA MUNICIPAL DE EDUCAÇÃO DO RIO DE JANEIRO. Multieducação: Relações de Ensino (Série Temas em Debate). Rio de Janeiro, 2007.

SEMEDO, Alice. Introdução: o domínio da prática. In: SEMEDO, Alice e LOPES, João Teixeira (Coord.) Museus, Discursos e Representações. Edições Afrontamento: Porto. pp.13-26, 2006.

SILVERSTONE, Roger. Por que estudar a mídia? São Paulo: Edições Loyola, 2002.

SOARES, José Francisco. Índice de Desenvolvimento da Educação de São Paulo - IDESP: bases metodológicas. São Paulo Perspectiva, São Paulo, v. 23, n. 1, p. 29-41, jan./jun. 2009.

Melhoria do desempenho cognitivo dos alunos do ensino fundamental. Cadernos de Pesquisa, São Paulo, v. 37, n. 130, p. 135160, 2007.

Qualidade e equidade na educação básica brasileira: fatos e possibilidades. In: BROCK, C. \& SCHWARTZMAN, S. Os desafios da educação no Brasil. Rio de Janeiro: Nova Fronteira, p. 91-110, 2005.

O efeito da escola no desempenho cognitivo de seus alunos. Revista Electrónica Iberoamericana sobre Calidad, Eficacia y Cambio en Educación. Vol. 2, n. 2, pp. 83-104, 2004.

SOARES, J. F. \& ANDRADE, R. J. de. Nível socioeconômico, qualidade e equidade das escolas de Nelo Horizonte. Ensaio: aval. pol. públ. Educ., Rio de Janeiro, v.14, n.50, p. 107-126, jan./mar. 2006 
SOARES, José Francisco \& DELGADO, Victor Maia Senna. Medidas das desigualdades de aprendizado entre estudantes de ensino fundamental. Est. Aval. Educ., São Paulo, v. 27, n. 66, p. 754-780, set./dez. 2016

SOARES, José Francisco. \& MAROTTA, L. Desigualdades no sistema de ensino fundamental brasileiro. In: VELOSO, F. et al. (Orgs.). Educação básica no Brasil: construindo o país do futuro. Rio de Janeiro: Elsevier, p. 73-91, 2009.

SORDI, Mara R. L de. Implicações ético-epistemológicas da negociação nos processos de avaliação institucional participativa. Educação e Sociedade. vol.33, n.119, pp. 485-510, 2012.

SOUZA, Ângelo Ricardo. As relações entre os resultados da avaliação e os modelos de gestão escolar. Intermeio - Revista do Projeto de Pósgraduação em Educação da UFMS, volume 13, №25, jan-jul de 2007.

TOLENTINO, Átila Bezerra. Políticas públicas para museus: o suporte legal no ordenamento jurídico brasileiro. Revista CPC. São Paulo: Universidade de São Paulo (USP), n. 4, mai./out., p.72-86, 2007.

TRILLA, J. A educação não-formal. In: TRILLA,, J.; GHANEM, E. e ARANTES, V. (orgs.). Educação formal e não-formal: Pontos e contrapontos. São Paulo: Summus, pp. 15-58, 2008.

. La educación fuera de la escuela: enseñanza a distancia, por correspondência, por ordenador, radio, vídeo y otros médios no formales. Barcelona: Planeta, 179 p, 1985.

TURA, M. de L. R. A observação do Cotidiano Escolar. In: ZAGO, N. e outros. Itinerários de pesquisa: perspectivas qualitativas em sociologia da educação. Rio de Janeiro: DPA, pp. 183-206, 2003.

TOURAINE, Alain. Um novo paradigma para compreender o mundo de hoje. São Paulo: Vozes, 2006.

VIANNA, Heraldo M. Pesquisa em Educação: a observação. Série Pesquisa, vol. 5. Brasília: Plano Editora, 2003.

Avaliação: considerações teóricas e posicionamentos. Estudos em Avaliação Educacional. São Paulo: Fundação Carlos Chagas, n. 16, p. 5-35, 1997.

VIGOTSKY, Lev. Imaginação e criação na infância: ensaio psicológico: livro para professores. São Paulo: Ática, 2009, pp.135.

XIMENES, Salomão Barros. Responsabilidade educacional: concepções diferentes e riscos iminentes ao direito à educação. Educação e Sociedade. vol.33, n.119, pp. 353-377, 2012. 
WELSCH, Wolfgang. Estetização e estetização profunda ou: a respeito da atualidade do estético nos dias de hoje. In: Revista, v. 6, n. 9, p. 7-22, Porto Alegre, Maio/ 1995.

ZAGO, Nadir. A entrevista em seu processo de construção: reflexões com base na experiência prática de pesquisa. In: ZAGO, $\mathrm{N}$. e outros. Itinerários de pesquisa: perspectivas qualitativas em sociologia da educação. Rio de Janeiro: DPA, pp. 287-309, 2003.

http://provabrasil.inep.gov.br/historico - consulta em 20 de junho de 2013. 


\section{Anexos}

\section{Anexo I}

Distribuição dos equipamentos culturais pertencentes à prefeitura da cidade do Rio de Janeiro por CRE.

\begin{tabular}{|c|c|c|}
\hline $\begin{array}{l}\text { Tipo de equipamento } \\
\text { cultural }\end{array}$ & Nome & CRE \\
\hline $\begin{array}{l}\text { Biblioteca Popular } \\
\text { Municipal }\end{array}$ & Biblioteca Popular da Gamboa & $1^{\mathrm{a}} \mathrm{CRE}$ \\
\hline Outros espaços de leitura & Biblioteca Popular Abgar Renault (CASS) & $1^{\mathrm{a}} \mathrm{CRE}$ \\
\hline Outros espaços de leitura & $\begin{array}{l}\text { Biblioteca Popular de Santa Teresa (no Centro } \\
\text { Cultural Municipal Laurinda Santos Lobo) }\end{array}$ & $1^{\mathrm{a}} \mathrm{CRE}$ \\
\hline Centro Cultural & Centro Municipal de Artes Calouste Gulbenkian & $1^{a} \mathrm{CRE}$ \\
\hline Centro Cultural & Centro Cultural Municipal José Bonifácio & $1^{\mathrm{a}} \mathrm{CRE}$ \\
\hline Centro Cultural & $\begin{array}{c}\text { Centro Cultural Municipal Laurinda Santos } \\
\text { Lobos }\end{array}$ & $1^{\mathrm{a}} \mathrm{CRE}$ \\
\hline Centro Cultural & Centro Cultural Municipal Parque das Ruínas & $1^{\mathrm{a}} \mathrm{CRE}$ \\
\hline Centro Cultural & Centro Municipal de Arte Hélio Oiticica & $1^{\text {a }} \mathrm{CRE}$ \\
\hline Museu & Ecomuseu & $1^{\mathrm{a}} \mathrm{CRE}$ \\
\hline Museu & MAR - MUSEU DE ARTE DO RIO & $1^{\mathrm{a}} \mathrm{CRE}$ \\
\hline Museu & Museu do Amanhã & $1^{\mathrm{a}} \mathrm{CRE}$ \\
\hline Teatro Municipal & Teatro Municipal Carlos Gomes & $1^{\mathrm{a}} \mathrm{CRE}$ \\
\hline Teatro Municipal & Teatro Gonzaguinha & $1^{\mathrm{a}} \mathrm{CRE}$ \\
\hline $\begin{array}{l}\text { Biblioteca Popular } \\
\text { Municipal }\end{array}$ & Biblioteca Popular de Botafogo & $2^{\mathrm{a}} \mathrm{CRE}$ \\
\hline $\begin{array}{l}\text { Biblioteca Popular } \\
\text { Municipal }\end{array}$ & Biblioteca Popular da Tijuca & $2^{\text {a }} \mathrm{CRE}$ \\
\hline Centro Cultural & Casas Casadas & $2^{\mathrm{a}} \mathrm{CRE}$ \\
\hline Centro Cultural & Centro Coreográfico da Cidade do Rio de Janeiro & $2^{\mathrm{a}} \mathrm{CRE}$ \\
\hline Centro Cultural & $\begin{array}{l}\text { Centro Cultural Municipal Oduvaldo Vianna } \\
\text { Filho Centro Carioca de Referência do Humor } \\
\text { Gráfico (Castelinho do Flamengo) }\end{array}$ & $2^{\mathrm{a}} \mathrm{CRE}$ \\
\hline Centro Cultural & $\begin{array}{l}\text { Centro Municipal de Referência da Música } \\
\text { Carioca Arthur da Távola }\end{array}$ & $2^{\mathrm{a}} \mathrm{CRE}$ \\
\hline
\end{tabular}




\begin{tabular}{|c|c|c|}
\hline Museu & Memorial Municipal Getúlio Vargas & $2^{\mathrm{a}} \mathrm{CRE}$ \\
\hline Museu & Museu Histórico da Cidade do Rio de Janeiro & $2^{\mathrm{a}} \mathrm{CRE}$ \\
\hline Planetário & Fundação Planetário da Cidade do Rio de Janeiro & $2^{\mathrm{a}} \mathrm{CRE}$ \\
\hline Teatro Municipal & Teatro Municipal Maria Clara Machado & $2^{\mathrm{a}} \mathrm{CRE}$ \\
\hline Teatro Municipal & Sala Municipal Baden Powell & $2^{\mathrm{a}} \mathrm{CRE}$ \\
\hline Teatro Municipal & Teatro Municipal Ziembinski & $2^{\mathrm{a}} \mathrm{CRE}$ \\
\hline Teatro Municipal & Espaço Cultural Municipal Sérgio Porto & $2^{\mathrm{a}} \mathrm{CRE}$ \\
\hline Teatro Municipal & Teatro Municipal Café Pequeno & $2^{\mathrm{a}} \mathrm{CRE}$ \\
\hline Teatro Municipal & $\begin{array}{l}\text { Teatro Municipal Do Jockey - Centro De } \\
\text { Referência Cultura Infância }\end{array}$ & $2^{\mathrm{a}} \mathrm{CRE}$ \\
\hline Teatro Municipal & Teatro Ipanema & $2^{\mathrm{a}} \mathrm{CRE}$ \\
\hline Teatro de Guignol & $\begin{array}{c}\text { Teatro de Fantoches e Marionetes Carlos } \\
\text { Werneck de Carvalho }\end{array}$ & $2^{\mathrm{a}} \mathrm{CRE}$ \\
\hline Teatro de Guignol & Teatro Municipal de Guignol da Tijuca & $2^{\mathrm{a}} \mathrm{CRE}$ \\
\hline Centro Cultural & Imperator - Centro Cultural João Nogueira & $3^{\mathrm{a}} \mathrm{CRE}$ \\
\hline Teatro de Guignol & Teatro Municipal de Guignol do Méier & $3^{\mathrm{a}} \mathrm{CRE}$ \\
\hline Outros espaços de leitura & $\begin{array}{l}\text { Biblioteca Popular da Maré (dentro da Lona } \\
\text { Cultural Municipal Herbert Vianna) }\end{array}$ & $4^{\mathrm{a}} \mathrm{CRE}$ \\
\hline Arena & $\begin{array}{c}\text { Arena Carioca Dicró - Carlos Roberto de } \\
\text { Oliveira }\end{array}$ & $4^{\mathrm{a}} \mathrm{CRE}$ \\
\hline Lona Cultural & Lona Cultural Municipal Herbert Vianna - Maré & $4^{\mathrm{a}} \mathrm{CRE}$ \\
\hline Lona Cultural & $\begin{array}{l}\text { Lona Cultural Municipal João Bosco - Vista } \\
\text { Alegre }\end{array}$ & $4^{\mathrm{a}} \mathrm{CRE}$ \\
\hline Arena & Arena Carioca Fernando Torres & $5^{\mathrm{a}} \mathrm{CRE}$ \\
\hline $\begin{array}{l}\text { Biblioteca Popular } \\
\text { Municipal }\end{array}$ & Biblioteca Popular de Irajá & $5^{\mathrm{a}} \mathrm{CRE}$ \\
\hline Outros espaços de leitura & $\begin{array}{c}\text { Biblioteca Popular Volante (Administrativo na } \\
\text { Biblioteca Popular de Irajá) }\end{array}$ & $5^{\mathrm{a}} \mathrm{CRE}$ \\
\hline Arena & Arena Carioca Jovelina Pérola Negra & $6^{\mathrm{a}} \mathrm{CRE}$ \\
\hline Lona Cultural & $\begin{array}{c}\text { Lona Cultural Municipal Carlos Zéfiro - } \\
\text { Anchieta }\end{array}$ & $6^{\mathrm{a}} \mathrm{CRE}$ \\
\hline Lona Cultural & Lona Cultural Municipal Terra - Guadalupe & $6^{\mathrm{a}} \mathrm{CRE}$ \\
\hline $\begin{array}{l}\text { Biblioteca Popular } \\
\text { Municipal }\end{array}$ & Biblioteca Popular de Jacarepaguá & $7^{\mathrm{a}} \mathrm{CRE}$ \\
\hline
\end{tabular}




\begin{tabular}{|c|c|c|}
\hline Centro Cultural & $\begin{array}{c}\text { Centro Cultural Municipal Professora Dyla } \\
\text { Sylvia de Sá }\end{array}$ & $7^{\mathrm{a}} \mathrm{CRE}$ \\
\hline Lona Cultural & $\begin{array}{l}\text { Lona Cultural Municipal Jacob Do Bandolim - } \\
\text { Jacarepaguá }\end{array}$ & $7^{\mathrm{a}} \mathrm{CRE}$ \\
\hline Lona Cultural & $\begin{array}{l}\text { Lona Cultural Municipal Hermeto Pascoal - } \\
\text { Bangu }\end{array}$ & $8^{\mathrm{a}} \mathrm{CRE}$ \\
\hline Lona Cultural & Lona Cultural Municipal Gilberto Gil - Realengo & $8^{\mathrm{a}} \mathrm{CRE}$ \\
\hline $\begin{array}{l}\text { Biblioteca Popular } \\
\text { Municipal }\end{array}$ & Biblioteca Popular de Campo Grande & $9^{\mathrm{a}} \mathrm{CRE}$ \\
\hline Lona Cultural & $\begin{array}{l}\text { Lona Cultural Municipal Elza Osborne - Campo } \\
\text { Grande }\end{array}$ & $9^{\mathrm{a}} \mathrm{CRE}$ \\
\hline Arena & Arena Carioca Abelardo Barbosa - Chacrinha & $\begin{array}{c}10^{\mathrm{a}} \\
\mathrm{CRE}\end{array}$ \\
\hline Outros espaços de leitura & $\begin{array}{l}\text { Biblioteca Popular do Guandu (dentro da Lona } \\
\text { Cultural Municipal Sandra de Sá) }\end{array}$ & $\begin{array}{c}10^{\mathrm{a}} \\
\mathrm{CRE}\end{array}$ \\
\hline Lona Cultural & $\begin{array}{l}\text { Lona Cultural Municipal Sandra De Sá - Santa } \\
\text { Cruz }\end{array}$ & $\begin{array}{c}10^{\mathrm{a}} \\
\mathrm{CRE}\end{array}$ \\
\hline Planetário & Planetário de Santa Cruz & $\begin{array}{c}10^{\mathrm{a}} \\
\mathrm{CRE}\end{array}$ \\
\hline $\begin{array}{l}\text { Biblioteca Popular } \\
\text { Municipal }\end{array}$ & Biblioteca Popular da Ilha do Governador & $\begin{array}{c}11^{\mathrm{a}} \\
\mathrm{CRE}\end{array}$ \\
\hline Lona Cultural & $\begin{array}{c}\text { Lona Cultural Municipal Renato Russo - Ilha Do } \\
\text { Governador }\end{array}$ & $\begin{array}{c}11^{\mathrm{a}} \\
\mathrm{CRE}\end{array}$ \\
\hline
\end{tabular}




\section{Anexo II}

Roteiro para observação nas visitas às instituições culturais parceiras da SME no Projeto Escola e Museu.

Data:

Horário:

Nome da instituição:

Escola:

Número de alunos:

Número de responsáveis (especificar: professores, familiares, auxiliares, coordenadores):

Atividade realizada: (visita guiada, contação de história, dramatização etc.)

Responsável pela recepção (função):

Dados da instituição (tipologia, temática, informações gerais):

Alguns aspectos que podem ser observados ${ }^{105}$ :

- Qual é o "ritual" de chegada? De modo geral, o que se pode dizer sobre o espaço/ o "clima" da visita?

- O que o Museu pretende provocar no público escolar com o trabalho desenvolvido?

- Há algum procedimento antes da visita com os alunos? (combinados, roda de conversa, atividades)

- Qual a duração da visita?

- Quais aspectos da exposição são priorizados nas visitas guiadas para o público escolar?

- Existe alguma avaliação do trabalho educativo desenvolvido em visita ao Museu com o público escolar? (avaliação imediata, avaliação processual).

Roteiro de observação

- Quais são as ações/ metodologias/ Projetos utilizados no momento da visita?

${ }^{105}$ Adaptado do roteiro elaborado por Thamiris Bastos Lopes, doutoranda em Educação (PUCRio). 
- Qual é o comportamento dos alunos nas formas de interação adolescente adolescente / adolescente - mediador / adolescente - exposição - mediador/ adolescente - professor/ professor -mediador?

- Os processos de mediação utilizados contemplam as necessidades do público surgidas no momento da visita?

- Há atividades desenvolvidas posteriormente à visita ainda no museu? (observar diferentes ações/ metodologias)

- Quais atitudes e reações os alunos expressam ao término da visita?

- O grupo de crianças já visitou o Museu? É possível perceber alguma diferença dos que já visitaram anteriormente?

- Qual é o comportamento dos adultos/ responsáveis durante a visita? (com os alunos, com os educadores do museu)

- Qual a reação dos outros visitantes ao presenciarem o trabalho educativo do Museu com os alunos?

- Há alguma manifestação/ fala do grupo (alunos e/ ou adultos) quanto à possibilidade de retornar (ou não) ao Museu sem a presença da escola?

- É possível perceber alguma estratégia por parte do Museu para transformar o grupo de audiência Projetoda para audiência espontânea?

Diálogos/ cenas observadas 


\section{Anexo III}

\section{Roteiro de entrevista com os docentes}

1) Como chegou ao projeto Escola e Museu? Foi indicação da direção?

2) Como selecionou os 40 alunos participantes do projeto? Qual foi o critério?

3) Quais foram as motivações e expectativas para participar do projeto?

4) O que achou da mediação (ou não mediação) feita?

5) Considera o projeto um instrumento de formação docente? E de formação cultural? Pedir para explicar.

6) O projeto gerou alguma mudança em você? E nos alunos? E na escola? Quais mudanças? 


\section{Anexo IV}

\section{Termo de consentimento livre e esclarecido}

Prezado(a) professor(a):

Sou estudante do curso de pós-graduação em Educação na Pontifícia Universidade Católica (PUC-Rio). Estou realizando uma pesquisa sob supervisão do(a) professor(a) Cristina Carvalho e com autorização da SME, cujo objetivo é compreender e avaliar a formação cultural nos espaços não formais de educação no Projeto Escola e Museu.

Sua participação envolve uma breve entrevista, que será gravada se assim você permitir, e que tem a duração aproximada de 10 minutos.

A participação nesse estudo é voluntária e se você decidir não participar ou quiser desistir de continuar em qualquer momento, tem absoluta liberdade de fazêlo.

Na publicação dos resultados desta pesquisa, sua identidade e a da escola serão mantidas no mais rigoroso sigilo. Serão omitidas todas as informações que permitam identificá-lo(a).

Mesmo não tendo benefícios diretos em participar, indiretamente você estará contribuindo para a compreensão do fenômeno estudado e para a produção de conhecimento científico.

Quaisquer dúvidas relativas à pesquisa poderão ser esclarecidas pela pesquisadora Priscila Resinentti (gepemci@gmail.com), integrante do grupo de Estudo e Pesquisa em Museu, Cultura e Infância.

Atenciosamente

Nome e assinatura do(a) professor(a)

Local e data participante 


\section{Anexo V}

Desempenho das CREs no IDERio 2009 e 2010.

\begin{tabular}{|c|c|c|c|c|c|}
\hline CRE da escola & $\mathrm{N}$ & Mínimo & Máximo & Média & $\begin{array}{l}\text { Desvio- } \\
\text { padrão }\end{array}$ \\
\hline 1 Nota IDERio 2009 & 20 & 2,0 & 4,5 & 3,240 & ,6185 \\
\hline 1 Nota IDERIO 2010 & 20 & 3,1 & 6,1 & 3,885 & ,6699 \\
\hline 2 Nota IDERio 2009 & 41 & 2,2 & 5,9 & 3,651 & 8877 \\
\hline 2 Nota IDERIO 2010 & 43 & 2,5 & 5,9 & 3,981 & ,8279 \\
\hline 3 Nota IDERio 2009 & 38 & 2,3 & 5,0 & 3,416 & 6007 \\
\hline 3 Nota IDERIO 2010 & 38 & 2,6 & 5,4 & 4,029 & ,6653 \\
\hline 4 Nota IDERio 2009 & 58 & 1,6 & 6,0 & 3,334 &, 8447 \\
\hline 4 Nota IDERIO 2010 & 58 & 2,1 & 5,6 & 3,684 & ,7476 \\
\hline 5 Nota IDERio 2009 & 41 & 2,0 & 5,4 & 3,444 & ,7061 \\
\hline 5 Nota IDERIO 2010 & 43 & 3,0 & 5,7 & 4,030 & ,6650 \\
\hline 6 Nota IDERio 2009 & 19 & 2,5 & 4,3 & 3,363 & ,4657 \\
\hline 6 Nota IDERIO 2010 & 19 & 3,0 & 4,9 & 3,768 & ,5034 \\
\hline 7 Nota IDERio 2009 & 38 & 2,6 & 5,7 & 3,803 & ,7449 \\
\hline 7 Nota IDERIO 2010 & 43 & 3,0 & 5,5 & 4,188 & ,5993 \\
\hline 8 Nota IDERio 2009 & 47 & 2,1 & 4,4 & 3,230 & 6168 \\
\hline 8 Nota IDERIO 2010 & 47 & 2,7 & 5,2 & 3,785 & ,5154 \\
\hline 9 Nota IDERio 2009 & 34 & 2,3 & 5,1 & 3,491 & ,6147 \\
\hline 9 Nota IDERIO 2010 & 34 & 3,2 & 5,2 & 4,247 & ,4653 \\
\hline 10 Nota IDERio 2009 & 39 & 2,2 & 4,1 & 3,359 & 5349 \\
\hline 10 Nota IDERIO 2010 & 40 & 2,9 & 4,8 & 3,885 & ,4566 \\
\hline
\end{tabular}

